\title{
Self-direction in return-to-work: bottlenecks, facilitators and an intervention
}

Citation for published version (APA):

Hoefsmit, N. (2015). Self-direction in return-to-work: bottlenecks, facilitators and an intervention. [Doctoral Thesis, Maastricht University]. Datawyse / Universitaire Pers Maastricht.

https://doi.org/10.26481/dis.20150402nh

Document status and date:

Published: 01/01/2015

DOI:

10.26481/dis.20150402nh

Document Version:

Publisher's PDF, also known as Version of record

\section{Please check the document version of this publication:}

- A submitted manuscript is the version of the article upon submission and before peer-review. There can be important differences between the submitted version and the official published version of record.

People interested in the research are advised to contact the author for the final version of the publication, or visit the DOI to the publisher's website.

- The final author version and the galley proof are versions of the publication after peer review.

- The final published version features the final layout of the paper including the volume, issue and page numbers.

Link to publication

\footnotetext{
General rights rights.

- You may freely distribute the URL identifying the publication in the public portal. please follow below link for the End User Agreement:

www.umlib.nl/taverne-license

Take down policy

If you believe that this document breaches copyright please contact us at:

repository@maastrichtuniversity.nl

providing details and we will investigate your claim.
}

Copyright and moral rights for the publications made accessible in the public portal are retained by the authors and/or other copyright owners and it is a condition of accessing publications that users recognise and abide by the legal requirements associated with these

- Users may download and print one copy of any publication from the public portal for the purpose of private study or research.

- You may not further distribute the material or use it for any profit-making activity or commercial gain

If the publication is distributed under the terms of Article $25 \mathrm{fa}$ of the Dutch Copyright Act, indicated by the "Taverne" license above, 


\section{SELF-DIRECTION IN RETURN-TO-WORK:}

BOTTLENECKS, FACILITATORS AND AN INTERVENTION
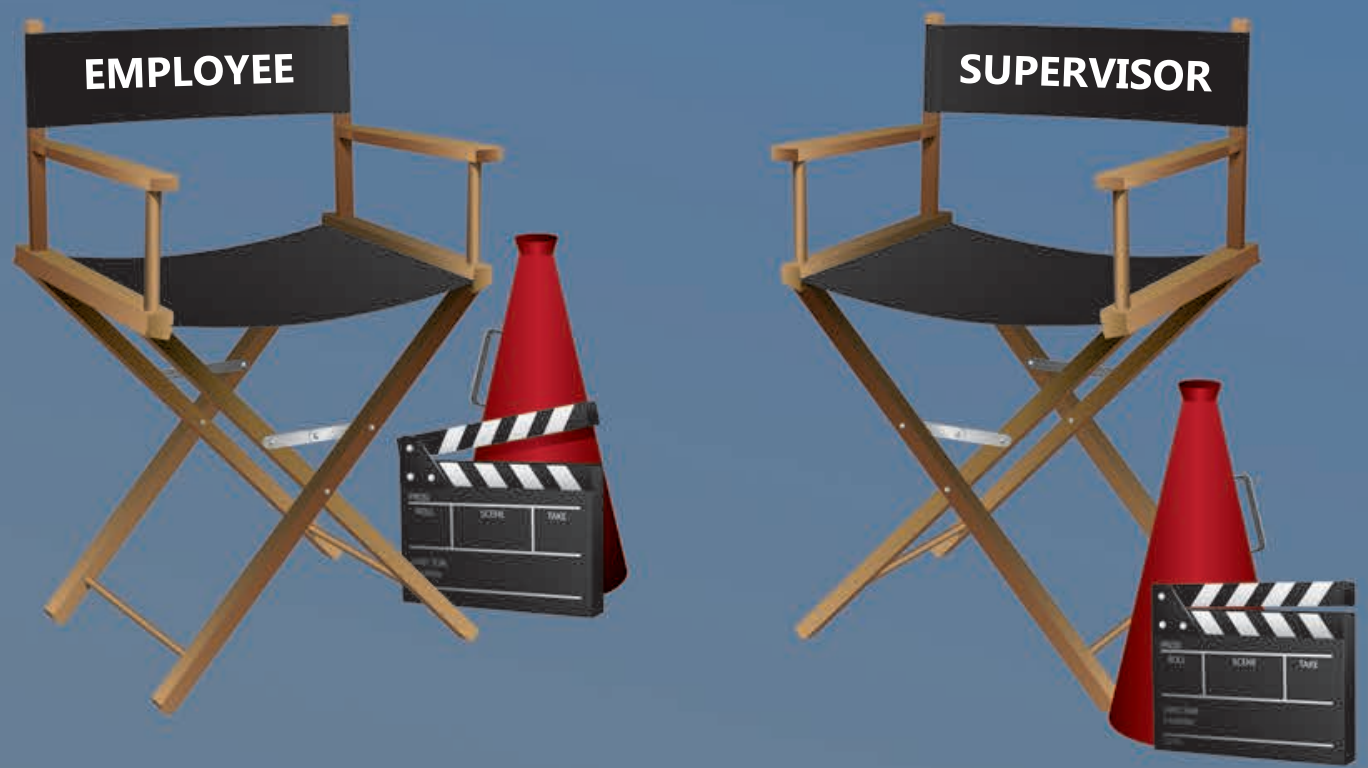
ISBN 9789461594211

(c) Copyright Nicole Hoefsmit, Maastricht 2015 


\title{
SELF-DIRECTION IN RETURN-TO-WORK: bottlenecks, facilitators and an intervention
}

\author{
DISSERTATION \\ To obtain the degree of Doctor at Maastricht University, \\ on the authority of the Rector Magnificus, \\ Prof. dr. L.L.G. Soete \\ in accordance with the decision of the Board of Deans, \\ to be defended in public \\ on 2 April 2015 at $12.00 \mathrm{hrs}$
}

by

Nicole Hoefsmit

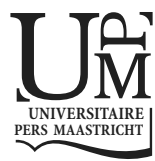




\section{Promotor}

Prof. dr. F.J.N. Nijhuis

\section{Co-promotores}

Dr. I. Houkes

Dr. N. Boumans

\section{Assessment Committee}

Prof. dr. F.R.H. Zijlstra (Chairman)

Prof. dr. J.R. Anema (EMGO institute, Vumc)

Prof. dr. H. Bosma

Prof. dr. S. Brouwer (Rijksuniversiteit Groningen)

Prof. dr. IJ. Kant

The research presented in this thesis was conducted at the School for Public Health and Primary Care: CAPHRI, Department of Social Medicine, of Maastricht University. CAPHRI participates in the Netherlands School of Primary Care Research CaRe. The research was funded by Stichting Instituut Gak-SIG. 
Aan mijn ouders 



\section{Contents}

CHAPTER 1 General Introduction

CHAPTER 2 Intervention characteristics that facilitate return to work after

sickness absence: a systematic literature review

CHAPTER 3 Environmental and personal factors that support early return-to- work: a qualitative study using the ICF as a framework

CHAPTER 4 Work resumption at the price of distrust: a qualitative study on return to work legislation in the Netherlands

CHAPTER 5 A process evaluation of a return-to-work intervention to improve cooperation between sick-listed employees and their supervisors (COSS)

CHAPTER 6 The effectiveness of an intervention to enhance cooperation between sick-listed employees and their supervisors (COSS)

CHAPTER 7 Economic evaluation of a new organizational RTW intervention to improve cooperation between sick-listed employees and their supervisors (COSS): a field study

CHAPTER 8 General Discussion

Appendix 1

Summary

Samenvatting

Valorisation of the research findings

Dankwoord

About the author 

CHAPTER 1

General Introduction 

Early return-to-work (RTW) is generally considered to be important for employees' health and quality of life. There is broad consensus that work can be therapeutic and that it supports independence of individuals [1]. Also, as sick leave proceeds, absent employees are increasingly at risk of becoming unemployed, which is disadvantageous for their health and financial position [1-2]. At the same time, employers, insurance companies and governments face an overly high financial burden. This includes the costs related to sick pay and replacement, costs of professional support (for example provided by OPs), as well as specialised healthcare costs [3]. Moreover, long-term sick leave does not fit in with the aim of many Western governments to enhance long-term labour participation of their citizens [4]. Multiple disciplines including employers, insurers and disability groups generally endorse the idea that sick-listed employees should resume work as soon as their health complaints allow them to [1].

It has been known for years however, that in practice there are bottlenecks concerning the cooperation between employees and employers (e.g. supervisors) as well as bottlenecks related to both stakeholders separately. An example of the latter is employees' lack of self efficacy. Both employees and employers tend to rely heavily on curative- and RTW professionals for achieving the employees' RTW while there is a lack of responsiveness of professionals towards the RTW-needs of sick-listed employees [5$6]$.

More specifically, on the one hand bottlenecks can concern employees and employers. Examples are a lack of communication between workplace stakeholders, conflicts at work, or a lack of employee trust in their supervisors [7-11]. Bottlenecks can also concern employees and their health complaints, such as the severity of health complaints, or fear that the complaint continues or worsens, a lack of co-operativeness, an avoidant coping style, private circumstances or general factors such as a lower education [7-12].

On the other hand, bottlenecks concern professional support. Examples are a lack of accountability and flexibility of the RTW system, a lack of research/guidelines regarding RTW, a lack of (quick) access to healthcare, the duration of curative treatment, a lack of client-centeredness in professionals or treating physicians who lack knowledge about the workplace $[7,11,13]$. In addition, research has shown a lack of communication and agreement (e.g. about bottlenecks for RTW) between the general practitioner and the occupational physician [7].

Overall, these bottlenecks illustrate a necessity for employees and supervisors (as representatives of employers) to cooperate better. It is important that employees and supervisors take this responsibility together, because these two stakeholders are most directly involved in employees' sick leave and work resumption. To take this responsibility, self-direction is a prerequisite. Considering the high material- and immaterial costs of delayed RTW described above, initiatives are necessary to support employees' and supervisors' self-direction in RTW. 


\section{Initiatives to support employees' and supervisors' self-direction in RTW}

Over the last decades, national and local governments and employers have developed policies and interventions to support sick-listed employees and their supervisors in selfdirection in RTW. These policies and interventions can be located at three institutional levels [14].

On the level of national legislation, the Dutch government for instance implemented the Improved Gatekeeper Act (2002) which prescribes a minimum degree of cooperation between sick-listed employees and their employers during maximally two years of sick leave [15-16]. During this period, the employer is expected to pay at least $70 \%$ of the employees' income [17]. Although sick leave has reduced and the employers' efforts during the first year have increased after introduction of this legislation, not all activities prescribed by the act are undertaken timely and bottlenecks for RTW remain unsolved. Findings of indicative research among a select group of employees show that tensions between employees and employers are visible even earlier due to the Improved Gatekeeper Act (as compared to the situation before the introduction of this legislation) $[9,18]$.

Second, regional and local policies have been developed. Recently, Maiwald, Meershoek, de Rijk, \& Nijhuis [19-20] have studied Canadian policy which aimed to involve employees and employers in RTW. An example rule of this policy is that employees contribute to their own early RTW-plan. However, in practice employees do not feel in control of their RTW and also supervisors are less involved in the employees' RTW-process than they should be according to the policy [19-20].

Third, at the individual level, many RTW interventions are offered, mostly by healthcare or insurers (see, for example, [21]). Yet, only few aim to enhance cooperation between individual sick-listed employees and their supervisors and thereby their self-direction in RTW [22-23].

\section{The need for generic, organisational RTW intervention}

Although the RTW interventions mentioned above are promising, they are often developed for employees with specific health issues such as burnout and are typically accessible through healthcare or insurers. This means that within a given organisation, only few employees and their supervisors are eligible for the intervention. This does not support successful RTW at organisational level.

Stakeholders in RTW such as employers, Occupational Health Services and social insurance offices need interventions they can provide to all absent employees. It is more feasible to apply one intervention to all absent employees instead of working with different interventions for several subgroups of employees (e.g. employees with different health complaints). Moreover, legislation can forbid employers to ask 
employees for their medical diagnoses as is the case in the Netherlands [15]. Thus, as not all employees will inform their employers about their health complaints, it is sometimes even impossible to apply RTW interventions that were developed for specific health complaints.

\section{Study aims}

In light of the above, we decided to develop and evaluate a generic (for all absent employees, regardless of their diagnoses) intervention, provided at an organisational level. To create a sound basis for this intervention, we made an overview of the current bottlenecks that inhibit sick listed employees' and their supervisors' to self-direct RTW. It was necessary to make such an overview because most previous studies of bottlenecks and facilitators of RTW were performed for specific target populations such as employees with contact dermatitis (see, for example [10]), included only one stakeholder perspective such as that of the employee (see, for example [13]), and/or did not provide sufficient and/or in-depth understanding, e.g. do not describe how factors play a role in RTW [10].

Therefore, the aims of this research were:

I) to create an overview of the facilitators of- and bottlenecks for sick-listed employees' and their supervisors' self-direction in RTW in multiple target populations and across interventions

II) to develop and evaluate a generic, organisational intervention to support sick-listed employees' and their supervisors' self-direction in RTW

This study is highly innovative because to our knowledge there exists no evidence-based generic and organisational intervention. The results of this study will support policy makers and RTW professionals such as occupational physicians to decide about the further implementation of initiatives to enhance cooperation between sick-listed employees and their supervisors.

This study is part of a bigger research project 'Work and Care'. In this project, multiple interventions are developed and/or evaluated to resolve bottlenecks for RTW in the workplace or in primary or secondary healthcare [5]. The results of the combined studies in the project 'Work and Care' can inform decision making at a national level about the future of RTW-support. 


\section{Setting of this study: return-to-work legislation in the Netherlands}

National and regional policies are the context in which employees' and employers' role taking regarding RTW takes place (see, for example, [19-20]). This study took place in the Netherlands, which is a unique case. As described earlier, here legislation is in force that makes employers financially responsible for absent employees during maximally two years of sick leave (Act on Wage Payment during Two Years). According to the Dutch Improved Gatekeeper Act, cooperation between absent employees and their employers should be the key to employees' early and adequate RTW. Legislation prescribes several activities to be performed by employees and employers such as writing an action plan for RTW and a regular monitoring of its progress. If necessary, employers should adapt the employees' work and/or workplace and employees should accept this offer. The employees' and employers' efforts to achieve the employees' RTW are evaluated by the social insurer. In case employees or employers fail to act as prescribed by the legislation, they can be sanctioned financially. When both employees and their employers made sufficient effort, and the employees fit the criteria, employees receive a disability pension after two years of sick leave, and after an assessment by the social insurer. Formally, the occupational physician has a limited role, i.e. to conduct a problem analysis that describes why employees are unable to work, their possibilities for medical recovery and the employees' expectations regarding the time to RTW [15-17]. However, in practice, many employers rely heavily on OPs for fulfilling their legal obligations during the whole period of sick leave.

\section{Outline of this thesis}

This study consisted of six studies that together meet both aims of this thesis. Studies 13 were performed for the first thesis aim, and studies 4-6 were performed with regard to the second aim of this thesis. Studies 1-2 were focused on the wide scope of all types of work- and healthcare related bottlenecks and facilitators, while studies 3-6 were focused on the cooperation between absent employees and their employers (c.q. supervisors and/or HR professionals) only.

The first study was a systematic literature review (study 1 ). We made this review in order to create an overview of intervention characteristics that facilitate RTW. We included 23 studies in total, which were assessed for their methodological quality. We applied our self-developed taxonomy to evaluate several intervention characteristics in the field of self-direction in RTW. The interventions included in the systematic review involved various stakeholders in the RTW process such as OP's and curative professionals, as well as employees.

Then, we performed a qualitative study in which we held in-depth interviews with employees, HR professionals and OPs in order to get insight in their perspectives on the 
environmental and personal factors that support RTW (study 2). RTW professionals such as OPs generally lack a framework for assessing the environmental and personal factors. The use of such a framework, however, can help to provide a standardised, minimum quality of professional support. This creates a lower dependency on the quality of support provided by individual professionals. Thus, we also studied the degree to which the ICF can be used as a framework to classify the environmental and personal factors [24]. The results of this qualitative study, among others, confirm the existence of a lack of adequate cooperation between- and self-direction by sick-listed employees and their supervisors.

To acquire more in-depth understanding of the cooperation between sick-listed employees and their employers, we performed a second qualitative study (study 3). Data from in-depth interviews with employees and HR professionals was used. We interviewed HR professionals because they have more extensive experience than supervisors with absent employees. In this study, we used the Resource Dependence Institutional Cooperation (RDIC) model, which combines different perspectives on cooperation and is developed especially for public health [25].

Based on the combined findings of these three studies, we developed an intervention to enhance Cooperation between Sick-listed employees and their Supervisors (COSS) (Appendix 1). This intervention consists of A) a 'conversation roadmap' for employees and their supervisors, which aims to structure and intensify the cooperation, B) a regular monitoring of the quality of this cooperation using an assessment instrument, and C) extra OP support to enhance cooperation if needed. cOSS was implemented in a large Dutch banking organisation.

This set the course for a process evaluation (study 4) to evaluate COSS's adoption and implementation, as well as an effect evaluation (study 5) and a cost -effectiveness, utility, and -benefit evaluation (study 6) of the intervention in a field study. The combination of these evaluation types enabled us to formulate recommendations from different perspectives about COSS as a strategy to support self-direction in RTW.

For the process evaluation, we used data from multiple stakeholders (i.e. employees, supervisors, OPs, organisation's representatives) and sources (i.e. interviews, conversation minutes, the researchers' project administration, email contact and an online questionnaire).

For the effect-, and cost- effectiveness, -utility, and -benefit evaluation, data were collected among employees using online questionnaires and the participating organisation's sick leave records.

Figure 1 provides an overview of the studies that were performed in this PhDproject. The figure illustrates the wide scope of studies 1-2, and the relatively narrow focus of studies 3-6.

Finally, the last chapter (8) provides a general discussion of this research. 

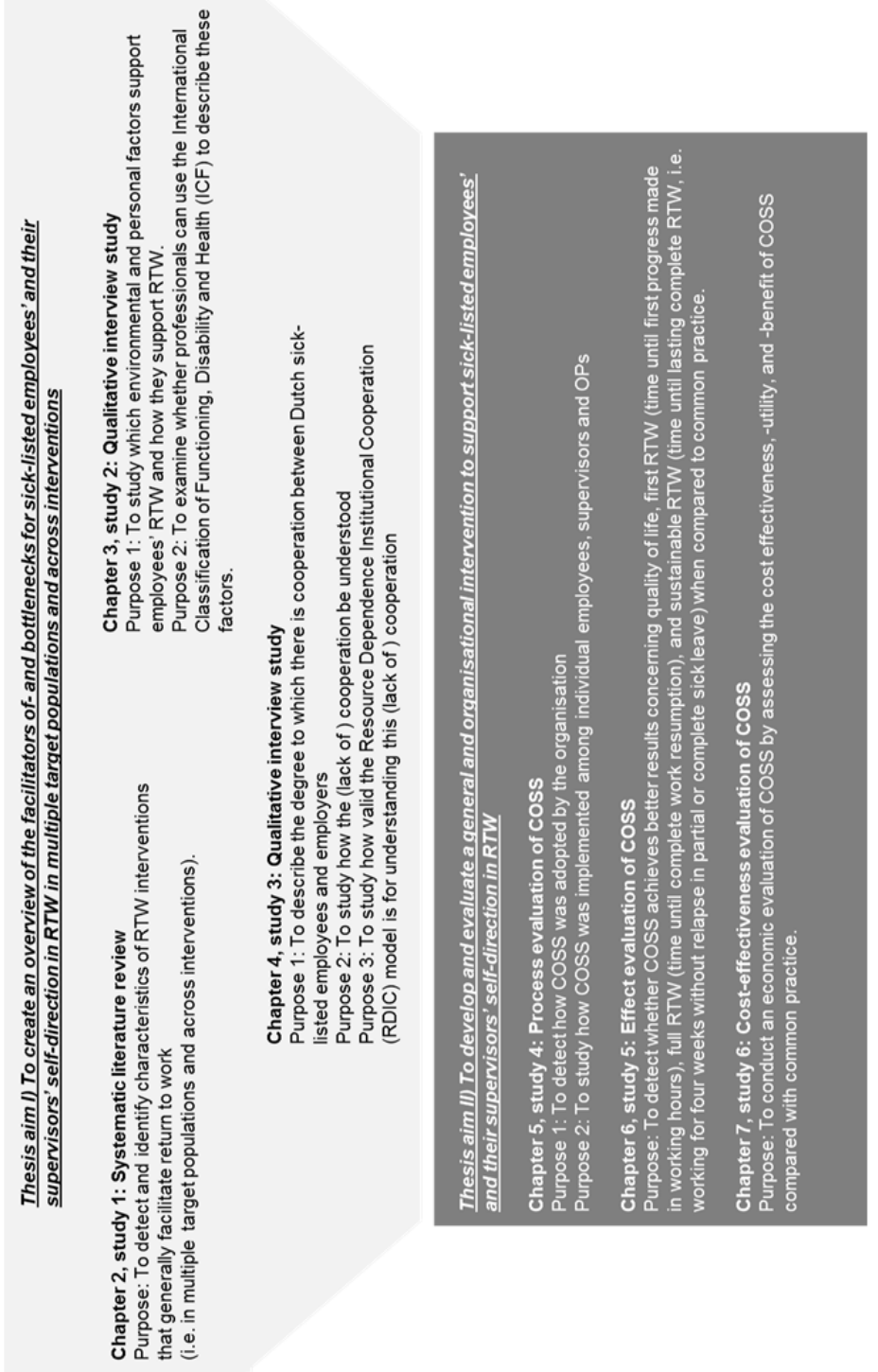

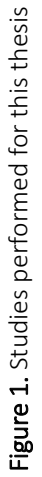




\section{Literature}

1. Waddell G, Burton AK. Is work good for your health and well-being? London: TSO; 2006.

2. Organisation for Economic Co-operation and Development. Sickness, Disability and Work: breaking the barriers. OECD. 2010. http://ec.europa.eu/health/mental_health/eu_compass/reports_studies/disability_synthesis_2010_en.pdf. Accessed 31 October 2013.

3. Black C. Working for a healthier tomorrow. London: TSO; 2008.

4. Annesley C. Lisbon and social Europe: towards a European 'adult worker model' welfare system. J Europe Soc Pol. 2007;17:195-205.

5. Berg M, Buijs P, Nijhuis F. Arbeid en Gezondheidszorg. Onderzoeksprogramma. Augustus 2008. [Work and Healthcare. Research programme. August 2008]. Plexus Medical Group, TNO Kwaliteit van Leven, Universiteit Maastricht. 2008. http://www.arbeidenzorg.com/uploads/programmabeschrijving\%20totaal_globaal_aug08.pdf. Accessed 30 July, 2014.

6. Hoefsmit N, Nijhuis FJN, Houkes I. Portfolio deelproject 1A. De vraagzijde: ontwikkelingen en uitdagingen [Portfolio sub project $1 \mathrm{~A}$. The demand side: developments and challenges]. Universiteit Maastricht. No date. http://www.arbeidenzorg.com/uploads/portfolio\%201a\%20universiteit\%20maastricht\%20april\%202010.pdf. Accessed 27 October 2014.

7. Anema JR, Jettinghoff K, Houtman ILD, Schoemaker CG, Buijs PC, van den Berg R. Medical care of employees long- term sick listed due to mental health problems: A cohort study to describe and compare the care of the occupational physician and the general practitioner. J Occ Rehab. 2006;16(1). DOI: 10.1007/s10926-005-9001-4.

8. Burger H, Marincek CRT. Return to work after lower limb amputation. Disabil Rehabil. 2007; 29:1323-9.

9. van Duijn $M$, Miedema $H$, Elders L, Burdorf A. Barriers for early return-to-work of workers with musculoskeletal disorders according to occupational health physicians and human resource managers. J Occup Rehab. 2004;14: 31-41.

10. Hollness DL. Return-to-work barriers for workers with contact dermatitis. Contact Dermatitis. 2004;49:273-5.

11. Schweigert MK, McNeil D, Doupe L. Treating physicians' perceptions of barriers to return to work of their patients in Southern Ontario. J Occup Med. 2004;54:425-9.

12. van Rhenen W, Schaufeli WB, van Dijk FJH, Blonk RWB. Coping and sickness absence. Int Arch Occ Environ Health. 2008;81 461-72.

13. Korzycki M, Korzyck, M, Shaw L. Left behind in the return-to-work journey: Consumer insights for policy change and practice strategies. WORK. 2008;30:277-87.

14. Scott WR. Institutions and organisations: Ideas and Interests (3rd ed.). Los Angeles: Sage Publications; 2008.

15. Ministry of Social affairs and Employment. Wet Verbetering Poortwachter [Improved Gatekeeper Act]. Ministry of Social affairs and Employment. No date. http://www.arboportaal.nl/onderwerpen/arbowet-en--regelgeving/verzuim/wet-verbetering-poortwachter.html. Accessed 6 March, 2013.

16. Ministry of Social affairs and Employment. Ziekteverzuim van het werk. [Sickness absence]. Ministry of Social affairs and Employment. No date. http://www.rijksoverheid.nl/onderwerpen/ziekteverzuim-vanhet-werk. Accessed 11 April, 2013

17. Overheid.nl. Wet Uitbreiding Loondoorbetalingsverplichting bij Ziekte [Act on Wage Payment during Two Years]. Overheid.nl. No date. http://wetten.overheid.nl/BWBR0007892/geldigheidsdatum_25-11-2013. Accessed 11 December 2013.

18. Reijenga FA, Veerman TJ, van den Berg N. Onderzoek evaluatie wet verbetering poortwachter [Evaluation of the Improved Gatekeeper Act]. Leiden: AStri; 2006.

19. Maiwald K, Meershoek A, de Rijk A, Nijhuis F. Policy on manager involvement in work re-integration: Managers' experiences in a Canadian setting. WORK. 2013. DOI: 10.3233/WOR-131727. 
20. Maiwald K, Meershoek A, de Rijk A, Nijhuis F. How policy on employee involvement in work reintegration can yield its opposite: employee experiences in a Canadian setting. Disabil Rehabil. 2013;35(7):527-37.

21. Ektor-Andersen J, Ingvarsson E, Kullendorff M, Orbaek P. High cost-benefit of early team-based biomedical and cognitive behaviour intervention for long-term pain-related sickness absence. J Rehab Med. 2008;40:1-8.

22. Karlson B, Jönsson P, Pålsson B, Åbjörnsson G, Malmberg B, Larsson B, \& Österberg K. Return to work after a workplace-oriented intervention for patients on sick-leave for burnout - a prospective controlled study. BMC Publ Health. 2010;10:301.

23. Karlson B, Jönsson P, Österberg K. Long-term stability of return to work after a workplace-oriented intervention for patients on sick leave for burnout. BMC Publ Health. 2014;14:281.

24. World Health Organization. ICF browser. World Health Organization. 2011. http://apps.who.int/classifications/icfbrowser/. Accessed 31 October, 2013.

25. de Rijk A, van Raak A, van der Made J. A new theoretical model for cooperation in public health settings: the RDIC model. Qual Health Res. 2007;17:1103-16. 


\section{CHAPTER 2}

\section{Intervention characteristics that facilitate}

return to work after sickness absence: a systematic literature review 


\section{Abstract}

Introduction: In many Western countries, a vast amount of interventions exist that aim to facilitate return to work (RTW) after sickness absence. These interventions are usually focused on specific target populations such as employees with low back pain, stress-related complaints or adjustment disorders. The aim of the present study is to detect and identify characteristics of RTW interventions that generally facilitate return to work (i.e. in multiple target populations and across interventions). This type of knowledge is highly relevant to policy makers and health practitioners who want to deliver evidence based care that supports the employee's health and participation in labour.

Methods: We performed a keyword search (systematic literature review) in seven databases (period: 1994-2010). In total, 23 articles were included and assessed for their methodological quality. The characteristics of the interventions were evaluated as well.

Results: Early interventions, initiated in the first 6 weeks of the RTW process were scarce. These were effective to support RTW though. Multidisciplinary interventions appeared effective to support RTW in multiple target groups (e.g. back pain and adjustment disorders). Time contingent interventions in which activities followed a predefined schedule were effective in all physical complaints studied in this review. Activating interventions such as gradual RTW were effective in physical complaints. They have not been studied for people with psychological complaints.

Conclusions: Early- and multidisciplinary intervention and time-contingent-, activating interventions appear most effective to support RTW. 


\section{Introduction}

Work can be beneficial for people's health, reversing the harmful effects of prolonged sickness absence on the employee's well-being. Improving the health and wellbeing of the working age population is critically important for individuals, organizations and society as a whole, in order to secure both higher economic growth and increased social justice [1]. In many Western countries, a large number of interventions exists to facilitate and hasten return to work (RTW) after sickness absence. These interventions include for example cognitive behavioural therapy [2], graded activity [3] and workplace adaptations [4].

Until now, systematic literature reviews that examined which interventions improved RTW, often focused on one diagnosis such as people with low back pain [5] or one intervention type such as interventions initiated by or integrated into the workplace, such as ergonomic work site visits [6]. However, we do not know yet whether and which intervention characteristics are generally effective, and therefore can be included in RTW interventions for multiple target populations. Therefore, the aim of this study is to detect and identify characteristics of RTW interventions that generally facilitate return to work (i.e. in multiple target populations and across interventions). Effective characteristics are part of RTW interventions that facilitate and hasten RTW, and at the same time are absent in interventions that do not facilitate RTW. We define facilitated RTW as either a significant reduction in the cumulate or mean number of (work, calendar or annual) days or weeks of sickness absence (whether or not measured at a certain follow up date) or an increase in work resumption rates (percentage of participants who resumed work partially or fully at a certain follow up date within the study period).

A problem, however, in this study is that standards by which we can classify RTW interventions do not exist yet. Therefore, we developed our own list of characteristics by which we classify the modern interventions that have been developed over the past two decades. This classification is based on earlier research $[2,4,5]$ and consultations with other expert researchers. It appeared that modern RTW interventions can be characterized by one or more of the following characteristics:

- Timing of intervention: early, initiated in the first 6 weeks of absence or not;

- Care professionals involved: multidisciplinary, including multiple professionals (care providers) from more than one discipline or not;

- Planning of activities to support RTW: time contingent, in which activities are performed according to a predefined schedule or not;

- Target population: all employees on sickness absence irrespective of their specific medical diagnosis (generic) or only to employees with a specific diagnosis (specific);

- Character of activities to support RTW: interventions including explicit actions to stimulate the employee to RTW, which are A: whether or not a decision was made 
as to when and/or how RTW will take place; B: whether or not there was gradual exposure to the workplace; and C: whether or not workplace adaptations were implemented;

- Intensity: a high ( $\geq 10 \mathrm{~h}$ divided over multiple sessions), moderate ( $<10 \mathrm{~h}$ divided over multiple sessions) or low intensity (once);

- Employee and employer role: decision latitude of the employee and/or employer about activities to support medical recovery or RTW and the timing of RTW or no decision latitude of the employee and/or employer.

Knowledge about intervention characteristics that facilitate RTW is highly relevant to the sick and absent employee who wants to consume care that optimally improves his/her health and the employer who aims to reduce productivity losses. Moreover, health, social security and insurance policy makers and practitioners can use this knowledge to deliver evidence based care that supports the employee's health and labour participation, thereby preventing future care consumption and dependence on benefits.

\section{Methods}

\section{Search}

We performed a systematic literature review. First, we searched Pubmed using the MeSH terms 'absenteeism', 'sick leave', 'absenteeism AND intervention studies', 'sick leave AND intervention studies'. We restricted the first two searches to studies in which the search terms were a 'major topic'. We searched for articles covering our keywords somewhere in the title, abstract or text body. Table 1 shows the results of this search.

Table 1. Databases, search terms, hits and included publications

\begin{tabular}{llll}
\hline Database & Key words & Number of hits & Number included \\
\hline Pubmed (MeSH) & Sick leave & 310 & 6 \\
& Sick leave AND intervention studies & 8 & 0 \\
& Absenteeism & 214 & 0 \\
& Absenteeism AND intervention studies & 7 & 0 \\
Pubmed & Return to work & 4560 & 7 \\
& Sickness absence & 1065 & 2 \\
Cinahl & Return to work & 248 & 1 \\
Gochrane library & Return to work & 63 & 1 \\
& Return to work & About 625.000 & 3 \\
& Return AND to AND work AND intervention & About 111.000 & 2 \\
Total & Early AND return AND to AND work & About 190.000 & 1 \\
\hline
\end{tabular}


Because searching Pubmed using the MeSH terms yielded only 6 relevant studies, we performed a broader keyword search in Pubmed, CINAHL, PsycINFO, Cochrane Library and Google Scholar. We searched all these databases by using various combinations of the following keywords: 'return to work', 'sickness absence', 'early', 'intervention', 'occupational', 'work', 'training', 'low', 'back', 'pain', 'whiplash', 'resumption', 'disability management', 'ergonomic'. Table 1 only shows only those keyword searches that yielded positive results. Titles and/or abstracts were screened until saturation (200 irrelevant hits in a row) was reached. We again searched for articles covering our keywords in the title, abstract or text body. We restricted the Cochrane search to reviews and the Google Scholar Search to the subject areas of Social Sciences, Arts and Humanities.

This procedure covered mostly recent articles, given the fact that the databases presented these first. Studies were included when they:

- Covered the effectiveness of interventions on RTW;

- Described interventions tested in a population of workers on sickness absence;

- Were full text articles;

- Were written in English and published in the last 16 years (from 1994 to 2010);

- Were empirical studies or systematic literature reviews.

We included systematic literature reviews to enlarge the body of evidence covered by this study. Such a large body of evidence is needed considering the broad scope of our study subject: to identify intervention characteristics facilitating RTW in multiple target populations (e.g. the employee on sickness absence with low back pain, psychological complaints, physical complaints etcetera). In total, 23 studies (18 quantitative studies and 5 systematic reviews) were included in this review.

We screened all literature lists of systematic literature reviews for overlap with the included empirical studies. In total 2 systematic reviews did not have any overlap with other empirical studies and 3 other reviews showed 3, 6 and 7\% overlap with empirical studies. Considering these relatively small percentages, we included both the systematic reviews and the empirical studies. We also searched the literature lists of the systematic reviews for other relevant articles that met the inclusion criteria. This search resulted in the inclusion of one additional empirical study [7].

\section{Analyses}

We assessed the methodological quality of all selected articles by means of the rating scheme presented in Table 2. Separate criteria were used for quantitative studies [largely based on 8] and systematic reviews [largely based on 9]. The criteria for quantitative studies are largely based on an existing tool from the Effective Public Health Practice Project [8]. The inter-rater reliability of the final grade assigned by this tool is considered excellent (intraclass correlation coefficient $=0.77,95 \%$ Confidence Interval 0.51-0.90) [10]. We took the methodological quality of the articles into account 


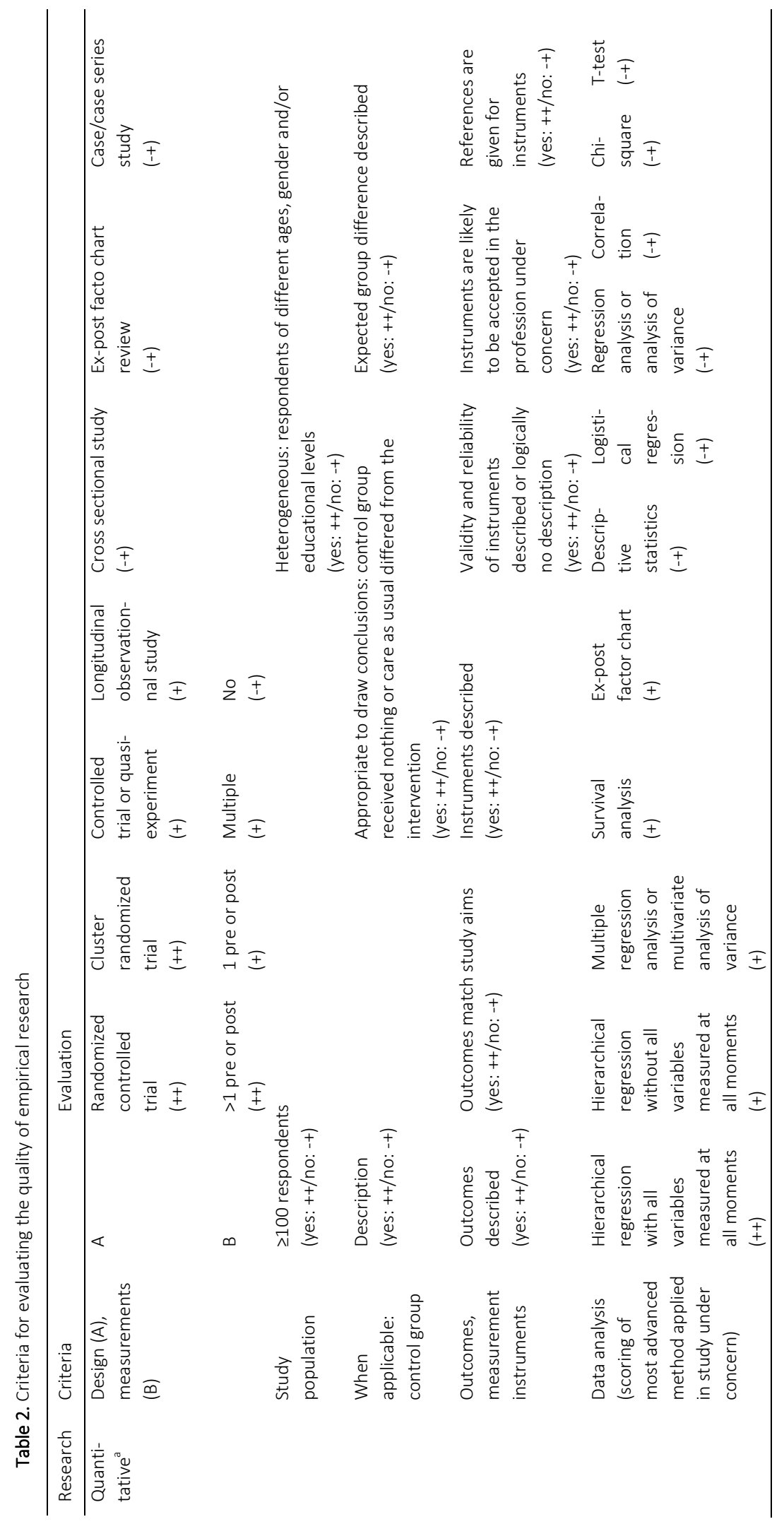




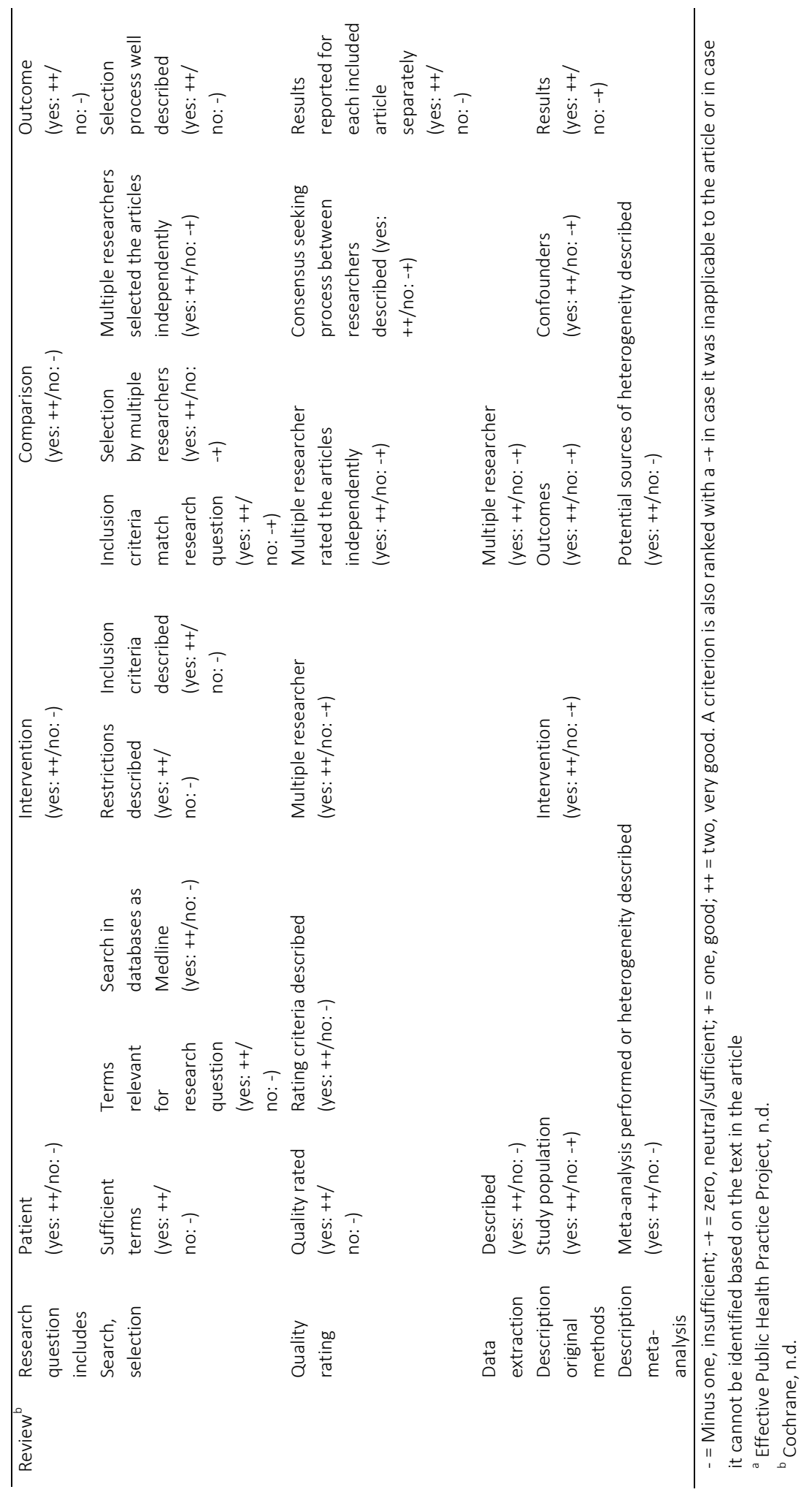


in our description of effective interventions by attaching more value to the higherquality studies. In case of inconsistent evidence, we attached more value to the highquality studies.

As regards the effectiveness of the interventions, data were extracted by reading and summarising articles. We used a standardised form that was developed for the purpose of this study. This form covered a description of the intervention and intervention characteristics, definitions of RTW/sickness absence and findings about the effectiveness of interventions. We included some systematic reviews in our study. We only read the primary studies in case the review article did not provide us all information needed to complete our form for data extraction.

To study the intervention characteristics that improve RTW, we defined several characteristics and developed a rating scheme by which we assessed all studies (Table 3).

When descriptions of original studies were insufficient to rate a characteristic, we did not take this study into account in the results for this characteristic. For the systematic literature reviews, we rated whether the characteristics applied to one or more original studies included in those reviews. When this was the case, we took the results of these original studies into account in our results. In case a characteristic such as timing of the start of intervention varied largely across the original studies in the review, we rated this characteristic as neutral.

The search and data analyses were discussed with peers. Please contact the corresponding author for more information about these procedures. 
Table 3. Criteria for evaluating the characteristics of the included interventions

\begin{tabular}{|c|c|c|c|c|}
\hline Intervention characteristic & Evaluation & & & \\
\hline $\begin{array}{l}\text { 1. Timing of intervention, early } \\
\text { which starts within first } 6 \text { weeks } \\
\text { of absence }\end{array}$ & Yes & \multicolumn{3}{|c|}{ No or timing not restricted } \\
\hline $\begin{array}{l}\text { 2. Care professionals involved, } \\
\text { multidisciplinary, involving } \\
\text { multiple professionals (care } \\
\text { providers) from more than one } \\
\text { discipline }\end{array}$ & Yes & \multicolumn{3}{|l|}{ No } \\
\hline $\begin{array}{l}\text { 3. Planning of activities to } \\
\text { support RTW, time-contingent, } \\
\text { activities followed pre-defined } \\
\text { time schedule }\end{array}$ & Yes & \multicolumn{3}{|l|}{ No } \\
\hline 4. Target population & $\begin{array}{l}\text { Generic: all } \\
\text { employees on } \\
\text { sickness absence } \\
\text { irrespective of their } \\
\text { specific medical } \\
\text { diagnosis }\end{array}$ & \multicolumn{3}{|l|}{$\begin{array}{l}\text { Specific: only } \\
\text { employees with } \\
\text { specific diagnosis }\end{array}$} \\
\hline \multirow[t]{2}{*}{$\begin{array}{l}\text { 5. Character of activities to } \\
\text { support RTW, interventions } \\
\text { including explicit actions to } \\
\text { stimulate the employee to RTW }\end{array}$} & $\begin{array}{l}\text { A: making decisions } \\
\text { about actual RTW } \\
\text { (when and/or how) }\end{array}$ & $\begin{array}{l}\text { B: gradual } \\
\text { exposure to the } \\
\text { workplace (for } \\
\text { example when } \\
\text { employees } \\
\text { resume work for } \\
\text { a limited but } \\
\text { increasing } \\
\text { number of hours } \\
\text { per week) }\end{array}$ & $\begin{array}{l}\text { C: } \\
\text { implemented } \\
\text { work- related } \\
\text { adaptations, } \\
\text { e.g. workplace } \\
\text { (such as } \\
\text { ergonomic } \\
\text { improvements } \\
\text { of furniture) }\end{array}$ & \\
\hline & Yes/no & Yes/no & Yes/no & \\
\hline 6. Intensity & $\begin{array}{l}\text { High: } \geq 10 \text { h divided } \\
\text { over multiple } \\
\text { sessions }\end{array}$ & $\begin{array}{l}\text { Moderate: }<10 \mathrm{~h} \text {, } \\
\text { multiple sessions }\end{array}$ & Low: once & Variable \\
\hline $\begin{array}{l}\text { 7. Employee and employer role, } \\
\text { decision latitude of the employee } \\
\text { and/or employer about activities } \\
\text { to support medical recovery or } \\
\text { RTW and (the timing of) RTW }\end{array}$ & Yes & No & & \\
\hline
\end{tabular}

Not described means that a certain characteristic is either not a part of the intervention or not described in the article. Not described is evaluated as a 'no'

Systematic reviews were evaluated by reading the descriptions of original studies that were included in the reviews. A 'no' was also attached in case original intervention studies varied largely or in the case of doubt 


\section{Results}

\section{Methodological quality of the studies}

Table 4 shows the methodological quality of the studies included in this review.

Table 4. Methodological quality of the included studies

\begin{tabular}{|c|c|c|c|c|c|c|}
\hline $\begin{array}{l}\text { Quantitative study } \\
\text { (in order of quality) }\end{array}$ & Design & Population & $\begin{array}{l}\text { Control } \\
\text { group }\end{array}$ & $\begin{array}{l}\text { Outcomes, } \\
\text { instruments }\end{array}$ & $\begin{array}{l}\text { Data } \\
\text { analysis }\end{array}$ & Score ${ }^{a}$ \\
\hline Brouwers et al. [11] & ++ & ++ & ++ & + & + & 8 (Good) \\
\hline $\begin{array}{l}\text { van der Feldtz-Cornelis et al. } \\
\text { [12] }\end{array}$ & ++ & ++ & ++ & + & + & 8 (Good) \\
\hline Mortelmans et al. [13] & ++ & ++ & ++ & + & + & 8 (Good) \\
\hline Bogefeldt et al. [18] & ++ & ++ & + & + & + & 7 (Good) \\
\hline Bültmann et al. [20] & ++ & ++ & ++ & + & -+ & 7 (Good) \\
\hline Fleten and Johnsen [24] & ++ & ++ & + & + & + & 7 (Good) \\
\hline van der Klink et al. [16] & ++ & ++ & + & + & + & 7 (Good) \\
\hline Arnetz et al. [19] & ++ & ++ & + & + & -+ & 6 (Good) \\
\hline Bakker et al. [29] & ++ & + & + & + & + & 6 (Good) \\
\hline Drews et al. [32] & + & ++ & + & + & + & 6 (Good) \\
\hline Hagen et al. [30] & ++ & ++ & + & + & -+ & 6 (Good) \\
\hline Nystuen and Hagen [31] & ++ & ++ & + & + & -+ & 6 (Good) \\
\hline Braathen et al. [25] & + & ++ & + & + & -+ & 5 (Moderate) \\
\hline Marhold et al. [23] & ++ & -+ & + & + & + & 5 (Moderate) \\
\hline Grossi and Santell [22] & ++ & -+ & + & + & -+ & 4 (Moderate) \\
\hline Godges et al. [26] & + & + & -+ & + & -+ & 3 (Moderate) \\
\hline Matheson and Brophy [21] & -+ & ++ & -+ & + & -+ & 3 (Moderate) \\
\hline Weiler et al. [15] & + & -+ & -+ & + & + & 3 (Moderate) \\
\hline
\end{tabular}

\begin{tabular}{llllllll}
\hline $\begin{array}{l}\text { Review } \\
\text { (in order } \\
\text { of quality) }\end{array}$ & $\begin{array}{l}\text { Research } \\
\text { question }\end{array}$ & Search & $\begin{array}{l}\text { Quality } \\
\text { evaluation }\end{array}$ & $\begin{array}{l}\text { Data } \\
\text { extraction }\end{array}$ & $\begin{array}{l}\text { Description } \\
\text { methods } \\
\text { original studies }\end{array}$ & $\begin{array}{l}\text { Meta- } \\
\text { analysis }\end{array}$ & Score $^{\text {a }}$ \\
\hline van Oostrom et al. ++ & ++ & ++ & ++ & ++ & ++ & 12 (Very good)
\end{tabular}

[14]

\begin{tabular}{|c|c|c|c|c|c|c|c|}
\hline Carroll et al. [17] & ++ & ++ & + & ++ & ++ & ++ & 11 (Very good) \\
\hline Meijer et al. [7] & + & + & + & - & ++ & ++ & 6 (Good) \\
\hline Norlund et al. [27] & + & + & -+ & - & ++ & ++ & 5 (Good) \\
\hline Tveito et al. [28] & + & - & ++ & - & + & - & 1 (Insufficient) \\
\hline
\end{tabular}

- = Minus one, insufficient; -+ = zero, neutral/sufficient; + = one, good; ++ = two, very good. A criteria is also ranked with a -+ in case it was inapplicable to the article or in case it cannot be identified based on the text in the article 
Methodological quality score of quantitative studies: -1 to 2 (insufficient), 3-5 (moderate), 6-8 (good), 9-11 (very good). Methodological quality of systematic reviews: -4 to 0 (insufficient), 1-4 (moderate), 5-8 (good), 9-12 (very good)

Methodological quality ranges: quantitative studies from -1 to 11, systematic literature reviews ranges from 4 to 12 . Mean scores are calculated when a criteria existed of multiple sub criteria. These mean scores were taken into account in the overall calculation of quality

${ }^{a}$ Final quality scores are calculated by adding up all pluses and subtracting all minuses

In general, the quantitative studies had moderate to good quality, relating to their designs, study populations, control groups and data analyses. Studies [11-13] were of the best quality because of their longitudinal designs, sufficiently large, heterogeneous study populations and adequate control groups. These studies also provided a complete description of the outcome variables, which also matched study aims. To measure the outcomes, instruments were used that are likely to be accepted by the relevant profession. Data were analysed with advanced techniques such as multilevel regression analyses.

The quality of four of the selected systematic literature reviews was good to very good. Review [14] was of the best quality. This review was based on an adequate research question, good search methods, selection, quality evaluation (and description of this procedure), data extraction and description of original studies. It included a meta-analysis and described potential sources of heterogeneity of studies included in the review.

Intervention characteristics and their effect on RTW

The interventions that were studied as well as their effects on RTW varied largely (Table $5)$.

All interventions were compared to care as usual or a control treatment or to the results of similar studies. In one study, a comparison was made between the number of sickness absence days before and after the intervention in a single group of employees (pre/post test, no control) [15]. This study reduced annual sick leave days for 2 years. We refer to this as a positive effect on RTW.

Table 6 shows the characteristics of each intervention. The interventions are listed in order of the intervention studies' methodological quality. 
Table 5. Description and effectiveness of the interventions

\begin{tabular}{|c|c|c|c|c|}
\hline Study & $\begin{array}{l}\text { Target } \\
\text { population }\end{array}$ & $\begin{array}{l}\text { Intervention and } \\
\text { care as usual }\end{array}$ & $\begin{array}{l}\text { Study outcomes most } \\
\text { relevant for this } \\
\text { review } \\
\text { (operationalisation of } \\
\text { return to work/ } \\
\text { sickness absence) }\end{array}$ & $\begin{array}{l}\text { Effectiveness } \\
\text { (on outcomes relevant to } \\
\text { this study) }\end{array}$ \\
\hline $\begin{array}{l}\text { Brouwers } \\
\text { et al. [11] }\end{array}$ & $\begin{array}{l}\text { Specific: only } \\
\text { employees } \\
\text { with specific } \\
\text { diagnosis } \\
\text { (emotional } \\
\text { and stress } \\
\text { related } \\
\text { complaints) }\end{array}$ & $\begin{array}{l}\text { Activating } \\
\text { counselling/control } \\
\text { group: care as } \\
\text { usual }\end{array}$ & $\begin{array}{l}\text { Sick leave duration } \\
\text { (days): period between } \\
\text { first day of } \\
\text { absence and return to } \\
\text { work }\end{array}$ & $\begin{array}{l}\text { No effect on sick leave } \\
\text { duration }\end{array}$ \\
\hline $\begin{array}{l}\text { van der } \\
\text { Feldtz- } \\
\text { Cornelis } \\
\text { et al. [12] }\end{array}$ & $\begin{array}{l}\text { Specific: only } \\
\text { employees } \\
\text { with specific } \\
\text { diagnosis } \\
\text { (depressive, } \\
\text { anxiety and } \\
\text { somatoform } \\
\text { disorders) }\end{array}$ & $\begin{array}{l}\text { (1) Training of } \\
\text { occupational } \\
\text { physicians in } \\
\text { diagnosis and } \\
\text { treatment (2) } \\
\text { supportive } \\
\text { psychiatric } \\
\text { consultations (3) } \\
\text { training of } \\
\text { psychiatrist/ } \\
\text { Control group: care } \\
\text { as usual }\end{array}$ & $\begin{array}{l}\text { Time to return to work: } \\
\text { period between onset } \\
\text { of sickness leave due to } \\
\text { mental disorder and full } \\
\text { return to work, for at } \\
\text { least } 4 \text { weeks without } \\
\text { relapse }\end{array}$ & $\begin{array}{l}\text { Full RTW at } 3 \text { months } \\
\text { follow up** survival } \\
\text { analysis: return } \\
\text { to work occurred } 122 \\
\text { (intervention) and } 190 \\
\text { days (control) after } \\
\text { intervention }\end{array}$ \\
\hline $\begin{array}{l}\text { Mortelmans } \\
\text { et al. [13] }\end{array}$ & $\begin{array}{l}\text { Generic: all } \\
\text { employees } \\
\text { on sickness } \\
\text { absence } \\
\text { irrespective } \\
\text { of their } \\
\text { specific } \\
\text { medical } \\
\text { diagnosis }\end{array}$ & $\begin{array}{l}\text { Structured and } \\
\text { circular } \\
\text { information } \\
\text { exchange by } \\
\text { communication } \\
\text { form/control } \\
\text { group: } \\
\text { occupational } \\
\text { physician filled out } \\
\text { the communication } \\
\text { form and delivered } \\
\text { to the researcher }\end{array}$ & $\begin{array}{l}\text { Return to work } \\
\text { rate/median } \\
\text { gradual return to work } \\
\text { duration in days }\end{array}$ & $\begin{array}{l}\text { No effect on return to } \\
\text { work rate. Relative risk: } \\
1.03 \text { ( } 95 \% \mathrm{Cl} 0.93- \\
1.13 \text { )/no effect on gradual } \\
\text { return to work rate. } \\
\text { Relative risk: } 1.24 \text { ( } 95 \% \mathrm{Cl} \\
0.52-2.97 \text { ). No difference } \\
\text { in median duration of } \\
\text { gradual return to work ( } 62 \\
\text { days) }\end{array}$ \\
\hline $\begin{array}{l}\text { Bogefeldt } \\
\text { et al. [18] }\end{array}$ & $\begin{array}{l}\text { Specific: only } \\
\text { employees } \\
\text { with specific } \\
\text { diagnosis } \\
\text { (low back } \\
\text { pain) }\end{array}$ & $\begin{array}{l}\text { Group 1: stay } \\
\text { active therapy (e.g. } \\
\text { exercise), } \\
\text { stretching, manual } \\
\text { therapy. Group 2: } \\
\text { stay active therapy, } \\
\text { stretching, manual } \\
\text { therapy, } \\
\text { corticosteroid } \\
\text { injections/ control } \\
\text { Group 1: stay }\end{array}$ & $\begin{array}{l}\text { Return to work } \\
\text { rate./Sick leave in days } \\
\text { (number of days times } \\
\text { sick leave extent) }\end{array}$ & $\begin{array}{l}\text { Increase return to work } \\
\text { after } 10 \text { weeks** (hazard } \\
\text { ratio } 1.62,95 \% \mathrm{Cl}, 1.006- \\
2.60, \mathrm{P}<0.05 \text { ) and among } \\
\text { those on sick leave at } \\
\text { baseline, significantly } \\
\text { fewer were still on sick } \\
\text { leave** (ratio } 0.35,95 \% \\
\mathrm{Cl}, 0.13-0.97, \mathrm{P}< \\
0.05) /(\text { no effect after } 2 \\
\text { years) }\end{array}$ \\
\hline
\end{tabular}




\begin{tabular}{|c|c|c|c|c|}
\hline Study & $\begin{array}{l}\text { Target } \\
\text { population }\end{array}$ & $\begin{array}{l}\text { Intervention and } \\
\text { care as usual }\end{array}$ & $\begin{array}{l}\text { Study outcomes most } \\
\text { relevant for this } \\
\text { review } \\
\text { (operationalisation of } \\
\text { return to work/ } \\
\text { sickness absence) }\end{array}$ & $\begin{array}{l}\text { Effectiveness } \\
\text { (on outcomes relevant to } \\
\text { this study) }\end{array}$ \\
\hline & & $\begin{array}{l}\text { active therapy } \\
\text { Group 2: stay } \\
\text { active therapy, } \\
\text { stretching }\end{array}$ & & \\
\hline $\begin{array}{l}\text { Bültmann } \\
\text { et al. [20] }\end{array}$ & $\begin{array}{l}\text { Specific: only } \\
\text { employees } \\
\text { with specific } \\
\text { diagnosis } \\
\text { (musculoskel } \\
\text { etal } \\
\text { complaints } \\
\text { or low back } \\
\text { pain) }\end{array}$ & $\begin{array}{l}\text { Systematic } \\
\text { multidisciplinary } \\
\text { work disability } \\
\text { screening, } \\
\text { development and } \\
\text { implementation of } \\
\text { work } \\
\text { rehabilitation } \\
\text { plan/control } \\
\text { group: care as } \\
\text { usual }\end{array}$ & $\begin{array}{l}\text { Cumulative sickness } \\
\text { absence hours, time } \\
\text { intervals: 0-3,3-6, 6- } \\
\text { 12, 0-6, 0-12 months }\end{array}$ & $\begin{array}{l}\text { Lower number of sickness } \\
\text { absence hours during } \\
\text { intervals } 0-6,6-12 \text { and } 0- \\
12^{* *} \text { /no effect during } \\
\text { intervals } 0-3-3-6\end{array}$ \\
\hline $\begin{array}{l}\text { Fleten and } \\
\text { Johnsen } \\
{[24]}\end{array}$ & $\begin{array}{l}\text { Specific: only } \\
\text { employees } \\
\text { with specific } \\
\text { diagnosis } \\
\text { (musculo- } \\
\text { skeletal or } \\
\text { mental } \\
\text { disorders) }\end{array}$ & $\begin{array}{l}\text { General } \\
\text { information letter } \\
\text { on possible work } \\
\text { related } \\
\text { measures if } \\
\text { sicklisted/control } \\
\text { group: care as } \\
\text { usual }\end{array}$ & $\begin{array}{l}\text { Length of sick leaves in } \\
\text { calendar days }\end{array}$ & $\begin{array}{l}\text { Reduction mean length of } \\
\text { sick leaves in subgroups } \\
\text { with mental disorders, } \\
\text { rheumatic disorders, } \\
\text { arthritis and in overall sick } \\
\text { leaves lasting } 12 \text { weeks or } \\
\text { more** }\end{array}$ \\
\hline $\begin{array}{l}\text { van der } \\
\text { Klink et al. } \\
{[16]}\end{array}$ & $\begin{array}{l}\text { Specific: only } \\
\text { employees } \\
\text { with specific } \\
\text { diagnosis } \\
\text { (adjustment } \\
\text { disorders) }\end{array}$ & $\begin{array}{l}\text { Graded } \\
\text { activity/control } \\
\text { group: care as } \\
\text { usual by the } \\
\text { occupational } \\
\text { physician }\end{array}$ & $\begin{array}{l}\text { Return to work rate: } \\
\text { percen-tage return to } \\
\text { work (partial or full) at } 3 \\
\text { months/duration of } \\
\text { Sick leave: days lost } \\
\text { until full } \\
\text { return to work with } \\
\text { correction for partial } \\
\text { return to work }\end{array}$ & $\begin{array}{l}\text { Increase return to work } \\
\text { rate at } 3 \text { months*** } \\
\text { shorter duration of sick } \\
\text { leave** rate ratio: } 2.39 \\
(95 \% \mathrm{Cl} 1.15-4.95)\end{array}$ \\
\hline
\end{tabular}




\begin{tabular}{|c|c|c|c|c|}
\hline Study & $\begin{array}{l}\text { Target } \\
\text { population }\end{array}$ & $\begin{array}{l}\text { Intervention and } \\
\text { care as usual }\end{array}$ & $\begin{array}{l}\text { Study outcomes most } \\
\text { relevant for this } \\
\text { review } \\
\text { (operationalisation of } \\
\text { return to work/ } \\
\text { sickness absence) }\end{array}$ & $\begin{array}{l}\text { Effectiveness } \\
\text { (on outcomes relevant to } \\
\text { this study) }\end{array}$ \\
\hline $\begin{array}{l}\text { Arnetz } \\
\text { et al. [19] }\end{array}$ & $\begin{array}{l}\text { Specific: only } \\
\text { employees } \\
\text { with specific } \\
\text { diagnosis } \\
\text { (musculoskel } \\
\text { etal } \\
\text { complaints) }\end{array}$ & $\begin{array}{l}\text { (A) Semistructured } \\
\text { interview with } \\
\text { employee on social } \\
\text { and occupational } \\
\text { situation. (B) } \\
\text { worksite visits by } \\
\text { team for } \\
\text { ergonomic } \\
\text { assessment and } \\
\text { improvements } \\
\text { and/or } \\
\text { personal vocational } \\
\text { training } \\
\text { schedule/control } \\
\text { group: care } \\
\text { as usual }\end{array}$ & $\begin{array}{l}\text { Sick leave: number of } \\
\text { sick days at } 6 \text { months } \\
\text { and at } 12 \text { months }\end{array}$ & $\begin{array}{l}\text { Shorter sick leave***/ } \\
\text { likelihood return to work } \\
\text { (odds ratio, OR) at } 6 \\
\text { months:1.9; } 95 \% \text { C.I. } 1.0 \text {; } \\
\text { 3.6, P =0.06/likelihood } \\
\text { return to work (OR) at } 12 \\
\text { months: } 2.5 ; 1.2 ; 5.1, \mathrm{P}< \\
0.01\end{array}$ \\
\hline $\begin{array}{l}\text { Bakker et } \\
\text { al. [29] }\end{array}$ & $\begin{array}{l}\text { Specific: only } \\
\text { employees } \\
\text { with } \\
\text { specific } \\
\text { diagnosis } \\
\text { (emotional } \\
\text { and stress } \\
\text { related } \\
\text { complaints) }\end{array}$ & $\begin{array}{l}\text { Communications } \\
\text { by general } \\
\text { practitioner to } \\
\text { promote functional } \\
\text { recovery (e.g. in } \\
\text { informing and } \\
\text { advising the } \\
\text { employee)/control } \\
\text { group: care as } \\
\text { usual }\end{array}$ & $\begin{array}{l}\text { Sick leave duration } \\
\text { (calendar days) from } \\
\text { the first day of sick } \\
\text { leave until full RTW }\end{array}$ & $\begin{array}{l}\text { No effect on sickness } \\
\text { absence duration/hazard } \\
\text { ratio: } 1.06 \\
(95 \% \mathrm{Cl} 0.87-1.29)\end{array}$ \\
\hline $\begin{array}{l}\text { Drews et } \\
\text { al. [32] }\end{array}$ & $\begin{array}{l}\text { Generic: all } \\
\text { employees } \\
\text { on } \\
\text { sickness } \\
\text { absence } \\
\text { irrespective } \\
\text { of their } \\
\text { specific } \\
\text { medical } \\
\text { diagnosis }\end{array}$ & $\begin{array}{l}\text { Social medicine } \\
\text { examination and } \\
\text { counselling/control } \\
\text { group: care as } \\
\text { usual }\end{array}$ & $\begin{array}{l}\text { Duration of sick leave } \\
\text { period from first day } \\
\text { until at least } 315 \\
\text { days/regular } \\
\text { employment } 1 \text { year } \\
\text { after intervention }\end{array}$ & $\begin{array}{l}\text { No effect on sickness } \\
\text { absence duration/no } \\
\text { effect on likelihood of } \\
\text { regular employment at } \\
\text { follow up/ odds ratio } \\
\text { intervention group: } 0.76 \\
\text { (95\% Cl } 0.45-1.28)\end{array}$ \\
\hline $\begin{array}{l}\text { Hagen et al. } \\
\text { [30] }\end{array}$ & $\begin{array}{l}\text { Specific: only } \\
\text { employees } \\
\text { with specific } \\
\text { diagnosis } \\
\text { (low back } \\
\text { pain) }\end{array}$ & $\begin{array}{l}\text { Physical exercise } \\
\text { program besides } \\
\text { control treatment/ } \\
\text { control group: } \\
\text { control treatment }\end{array}$ & Length of sick leave & $\begin{array}{l}\text { No (additional) effect on } \\
\text { sick leave }\end{array}$ \\
\hline
\end{tabular}




\begin{tabular}{|c|c|c|c|c|}
\hline Study & $\begin{array}{l}\text { Target } \\
\text { population }\end{array}$ & $\begin{array}{l}\text { Intervention and } \\
\text { care as usual }\end{array}$ & $\begin{array}{l}\text { Study outcomes most } \\
\text { relevant for this } \\
\text { review } \\
\text { (operationalisation of } \\
\text { return to work/ } \\
\text { sickness absence) }\end{array}$ & $\begin{array}{l}\text { Effectiveness } \\
\text { (on outcomes relevant to } \\
\text { this study) }\end{array}$ \\
\hline $\begin{array}{l}\text { Nystuen } \\
\text { and Hagen } \\
{[31]}\end{array}$ & $\begin{array}{l}\text { Specific: only } \\
\text { employees } \\
\text { with } \\
\text { specific } \\
\text { diagnosis } \\
\text { (musculoskel } \\
\text { etal } \\
\text { complaints) }\end{array}$ & $\begin{array}{l}\text { Solution-focused } \\
\text { intervention/ } \\
\text { control group: care } \\
\text { as usual }\end{array}$ & $\begin{array}{l}\text { Sick leave: mean length } \\
\text { after } 12 \text { months/work } \\
\text { status (at work or not) } 6 \\
\text { months after } \\
\text { intervention }\end{array}$ & $\begin{array}{l}\text { No effect on sick leave/no } \\
\text { effect on work status }\end{array}$ \\
\hline $\begin{array}{l}\text { Braathen } \\
\text { et al. [25] }\end{array}$ & $\begin{array}{l}\text { Generic: all } \\
\text { employees } \\
\text { on sickness } \\
\text { absence } \\
\text { irrespective } \\
\text { of their } \\
\text { specific } \\
\text { medical } \\
\text { diagnosis }\end{array}$ & $\begin{array}{l}\text { Multidisciplinary } \\
\text { rehabilitation } \\
\text { programme/ } \\
\text { control group: } \\
\text { treatment of } \\
\text { persons' own } \\
\text { choice }\end{array}$ & $\begin{array}{l}\text { Return to work: } \\
\text { percentage of } \\
\text { population who } \\
\text { resumed } \\
\text { work }\end{array}$ & $\begin{array}{l}\text { No effect on return to } \\
\text { work }\end{array}$ \\
\hline $\begin{array}{l}\text { Marhold } \\
\text { et al. [23] }\end{array}$ & $\begin{array}{l}\text { Specific: only } \\
\text { employees } \\
\text { with specific } \\
\text { diagnosis } \\
\text { (musculo- } \\
\text { skeletal } \\
\text { complaints) }\end{array}$ & $\begin{array}{l}\text { Pain coping skills } \\
\text { training, focus on: } \\
\text { how to return to } \\
\text { work and apply } \\
\text { coping skills to } \\
\text { occupational risk } \\
\text { factors/ control } \\
\text { group: care as } \\
\text { usual }\end{array}$ & $\begin{array}{l}\text { Sick leave (days) over } \\
\text { periods of } 2 \text { months ( } 2 \\
\text { months before } \\
\text { treatment and } 6 \\
\text { months follow up) }\end{array}$ & $\begin{array}{l}\text { Patients short-term sick } \\
\text { leave ( } 2-6 \text { months): } \\
\text { shorter sick } \\
\text { leave**/patients long- } \\
\text { term sick leave ( }>12 \\
\text { months): no effect on sick } \\
\text { leave }\end{array}$ \\
\hline $\begin{array}{l}\text { Grossi and } \\
\text { Santell [22] }\end{array}$ & $\begin{array}{l}\text { Specific: only } \\
\text { employees } \\
\text { with specific } \\
\text { diagnosis } \\
\text { (females on } \\
\text { sick leave } \\
\text { due to work- } \\
\text { related } \\
\text { psycholo- } \\
\text { gical } \\
\text { complaints) }\end{array}$ & $\begin{array}{l}\text { Coping with } \\
\text { psychological/ } \\
\text { somatic symptoms } \\
\text { of stress/ } \\
\text { control group: } \\
\text { standard } \\
\text { individual } \\
\text { treatment for } \\
\text { stress }\end{array}$ & $\begin{array}{l}\text { Return to work rate: } \\
\text { percentage of } \\
\text { population who } \\
\text { resumed work }\end{array}$ & $\begin{array}{l}\text { No effect on return to } \\
\text { work rate }\end{array}$ \\
\hline
\end{tabular}




\begin{tabular}{|c|c|c|c|c|}
\hline Study & $\begin{array}{l}\text { Target } \\
\text { population }\end{array}$ & $\begin{array}{l}\text { Intervention and } \\
\text { care as usual }\end{array}$ & $\begin{array}{l}\text { Study outcomes most } \\
\text { relevant for this } \\
\text { review } \\
\text { (operationalisation of } \\
\text { return to work/ } \\
\text { sickness absence) }\end{array}$ & $\begin{array}{l}\text { Effectiveness } \\
\text { (on outcomes relevant to } \\
\text { this study) }\end{array}$ \\
\hline $\begin{array}{l}\text { Godges et al. } \\
{[26]}\end{array}$ & $\begin{array}{l}\text { Specific: only } \\
\text { employees } \\
\text { with specific } \\
\text { diagnosis } \\
\text { (low back } \\
\text { pain) }\end{array}$ & $\begin{array}{l}\text { Education, } \\
\text { counseling on pain } \\
\text { management } \\
\text { tactics and value of } \\
\text { physical activity } \\
\text { besides } \\
\text { conventional } \\
\text { physical } \\
\text { therapy/control } \\
\text { group: } \\
\text { conventional } \\
\text { physical therapy }\end{array}$ & $\begin{array}{l}\text { Sick leave duration } \\
\text { (days) }\end{array}$ & $\begin{array}{l}\text { Shorter sickness absence } \\
\text { duration** }\end{array}$ \\
\hline $\begin{array}{l}\text { Matheson and } \\
\text { Brophy [21] }\end{array}$ & $\begin{array}{l}\text { Specific: only } \\
\text { employees } \\
\text { with specific } \\
\text { diagnosis } \\
\text { (low back } \\
\text { pain) }\end{array}$ & $\begin{array}{l}\text { Early return to } \\
\text { work in transitional } \\
\text { light duty work, } \\
\text { immediate } \\
\text { identification and } \\
\text { treatment during } \\
\text { work hours/ } \\
\text { Control group: not } \\
\text { applicable }\end{array}$ & $\begin{array}{l}\text { Return to work rate: } \\
\text { percentage of } \\
\text { population who } \\
\text { resumed work/days lost } \\
\text { from work }\end{array}$ & $\begin{array}{l}\text { Within } 30 \text { days, } 94 \% \text { of all } \\
\text { subjects had return to } \\
\text { work/ increase return to } \\
\text { work rate compared to } \\
\text { other studies/ mean } \\
\text { number of days lost from } \\
\text { work: } 8.8\end{array}$ \\
\hline $\begin{array}{l}\text { Weiler et } \\
\text { al. [15] }\end{array}$ & $\begin{array}{l}\text { Specific: only } \\
\text { employees } \\
\text { with specific } \\
\text { diagnosis } \\
\text { (musculoskel } \\
\text { etal } \\
\text { complaints) }\end{array}$ & $\begin{array}{l}\text { Outpatient } \\
\text { rehabilitation and } \\
\text { determination of } \\
\text { return to work } \\
\text { (regular, assisted or } \\
\text { individualised } \\
\text { procedure), } \\
\text { multidisciplinary } \\
\text { team conferences } \\
\text { (therapists and } \\
\text { Airbus health } \\
\text { professionals)/ } \\
\text { control group: not } \\
\text { described }\end{array}$ & $\begin{array}{l}\text { Return to work } \\
\text { ratios/annual sick leave } \\
\text { days (as compared to } \\
\text { before sick leave } \\
\text { period) }\end{array}$ & $\begin{array}{l}97 \% \text { of the Patients } \\
\text { returned to their original } \\
\text { job at the workplace. } \\
\text { Reduction annual sick } \\
\text { leave days from } \\
48.8 \pm 32.8 \text { days to } 34.2 \pm \\
37.3 \text { days***. } \\
\text { Intervention stabilised low } \\
\text { level annual sick leave } \\
\text { days during first } 2 \text { years of } \\
\text { follow-up }\end{array}$ \\
\hline
\end{tabular}




\begin{tabular}{|c|c|c|c|c|}
\hline Study & $\begin{array}{l}\text { Target } \\
\text { population }\end{array}$ & $\begin{array}{l}\text { Intervention and } \\
\text { care as usual }\end{array}$ & $\begin{array}{l}\text { Study outcomes most } \\
\text { relevant for this } \\
\text { review } \\
\text { (operationalisation of } \\
\text { return to work/ } \\
\text { sickness absence) }\end{array}$ & $\begin{array}{l}\text { Effectiveness } \\
\text { (on outcomes relevant to } \\
\text { this study) }\end{array}$ \\
\hline $\begin{array}{l}\text { van Oostrom } \\
\text { et al. [14] }\end{array}$ & $\begin{array}{l}\text { Specific: only } \\
\text { employees } \\
\text { with specific } \\
\text { diagnosis } \\
\text { (musculoskel } \\
\text { etal } \\
\text { complaints, } \\
\text { mental and } \\
\text { other health } \\
\text { problems) }\end{array}$ & $\begin{array}{l}\text { Interventions } \\
\text { directed at work/ } \\
\text { control group: care } \\
\text { as usual or clinical } \\
\text { interventions }\end{array}$ & $\begin{array}{l}\text { Time until a lasting } \\
\text { return to work: a period } \\
\text { of absence from the } \\
\text { first day of sick leave to } \\
\text { full return to work in } \\
\text { previous or equal work } \\
\text { for at least } 4 \text { weeks } \\
\text { without dropping } \\
\text { out/Time until first } \\
\text { return to work: period } \\
\text { of absence from work } \\
\text { because of sickness, } \\
\text { preceded and followed } \\
\text { by period of at least } 1 \\
\text { day at work/ } \\
\text { Cumulative duration of } \\
\text { sickness absence: total } \\
\text { days of sick leave during } \\
\text { follow-up period }\end{array}$ & $\begin{array}{l}\text { Shorter sickness absence } \\
\text { duration among workers } \\
\text { with musculoskeletal } \\
\text { disorders (moderate } \\
\text { evidence)/no conclusions } \\
\text { on effectiveness in mental } \\
\text { health problems and } \\
\text { other conditions due to } \\
\text { lack of studies/workplace } \\
\text { interventions: days until } \\
\text { lasting return to work, } \\
\text { relative effect hazard ratio } \\
\text { 1.70 (Cl 95\% 1.23-2.35), } \\
\text { days until first return to } \\
\text { work, relative effect } \\
\text { hazard ratio 1.55 (Cl 95\% } \\
\text { 1.32-2.16)/ mean } \\
\text { cumulative duration of } \\
\text { sickness absence: -39.06 } \\
\text { days }\end{array}$ \\
\hline $\begin{array}{l}\text { Carroll et } \\
\text { al. [17] }\end{array}$ & $\begin{array}{l}\text { Specific: only } \\
\text { employees } \\
\text { with specific } \\
\text { diagnosis } \\
\text { (back pain) }\end{array}$ & $\begin{array}{l}\text { Interventions } \\
\text { involving } \\
\text { workplace/control } \\
\text { group: } \\
\text { interventions not } \\
\text { involving workplace }\end{array}$ & $\begin{array}{l}\text { Multiple } \\
\text { operationalisations of } \\
\text { return to work among } \\
\text { which time to return to } \\
\text { work }\end{array}$ & $\begin{array}{l}\text { Interventions involving } \\
\text { employee, health } \\
\text { practitioner and employer } \\
\text { working together to } \\
\text { implement work } \\
\text { modifications, were more } \\
\text { consistently effective than } \\
\text { other workplace-linked } \\
\text { interventions }\end{array}$ \\
\hline $\begin{array}{l}\text { Meijer et } \\
\text { al. [7] }\end{array}$ & $\begin{array}{l}\text { Specific: only } \\
\text { employees } \\
\text { with specific } \\
\text { diagnosis } \\
\text { (non-specific } \\
\text { musculoskele } \\
\text { tal } \\
\text { complaints) }\end{array}$ & $\begin{array}{l}\text { Several } \\
\text { interventions/contr } \\
\text { ol group: care as } \\
\text { usual or } \\
\text { control treatment }\end{array}$ & $\begin{array}{l}\text { Difference in sick } \\
\text { leave after treatment as } \\
\text { compared to sick leave } \\
\text { preceding treatment }\end{array}$ & $\begin{array}{l}\text { Shorter sick leave } \\
\text { duration (significance not } \\
\text { described): } 7 \text { out of } 22 \\
\text { treatment programs } \\
\text { (inconsistent findings). } \\
\text { Essential to effective } \\
\text { treatment: knowledge, } \\
\text { psychological, physical } \\
\text { and work conditioning, } \\
\text { possibly supplemented } \\
\text { with relaxation exercises }\end{array}$ \\
\hline
\end{tabular}




\begin{tabular}{|c|c|c|c|c|}
\hline Study & $\begin{array}{l}\text { Target } \\
\text { population }\end{array}$ & $\begin{array}{l}\text { Intervention and } \\
\text { care as usual }\end{array}$ & $\begin{array}{l}\text { Study outcomes most } \\
\text { relevant for this } \\
\text { review } \\
\text { (operationalisation of } \\
\text { return to work/ } \\
\text { sickness absence) }\end{array}$ & $\begin{array}{l}\text { Effectiveness } \\
\text { (on outcomes relevant to } \\
\text { this study) }\end{array}$ \\
\hline $\begin{array}{l}\text { Norlund } \\
\text { et al. [27] }\end{array}$ & $\begin{array}{l}\text { Specific: only } \\
\text { employees } \\
\text { with specific } \\
\text { diagnosis } \\
\text { (low back } \\
\text { pain) }\end{array}$ & $\begin{array}{l}\text { Multidisciplinary } \\
\text { interventions/ } \\
\text { control group: } \\
\text { variable }\end{array}$ & $\begin{array}{l}\text { Return to work } \\
\text { (measured either } \\
\text { directly or indirectly as } \\
\text { days of sick leave after } \\
\text { start of rehabilitation, } \\
\text { with the opportunity to } \\
\text { turn sick leave into } \\
\text { RTW) }\end{array}$ & $\begin{array}{l}\text { Return to work: difference } \\
\text { of effect } 21 \% \text {, relative risk } \\
1.21,95 \% \mathrm{Cl} \text { in favour of } \\
\text { the intervention groups } \\
\text { (only Scandinavian } \\
\text { studies) }\end{array}$ \\
\hline $\begin{array}{l}\text { Tveito et al. } \\
\text { [28] }\end{array}$ & $\begin{array}{l}\text { Specific: only } \\
\text { employees } \\
\text { with specific } \\
\text { diagnosis } \\
\text { (low back } \\
\text { pain) }\end{array}$ & $\begin{array}{l}\text { Workplace } \\
\text { interventions/ } \\
\text { control group: not } \\
\text { described }\end{array}$ & $\begin{array}{l}\text { Lost work days or sick } \\
\text { leave due to low back } \\
\text { pain }\end{array}$ & $\begin{array}{l}\text { Exercise significantly } \\
\text { reduced sick leave } \\
\text { duration (limited } \\
\text { evidence, level of } \\
\text { significance not } \\
\text { described)/ interventions } \\
\text { to treat low back pain } \\
\text { have positive effects on } \\
\text { sick leave (moderate } \\
\text { evidence, levels of } \\
\text { significance not } \\
\text { described)/no evidence of } \\
\text { effect on sick leave from } \\
\text { educational intervention, } \\
\text { pamphlet, back } \\
\text { belts/limited evidence } \\
\text { that multidisciplinary } \\
\text { interventions have no } \\
\text { effect on sick leave (level } \\
\text { of significance not } \\
\text { described) }\end{array}$ \\
\hline
\end{tabular}

** $\mathrm{P}<0.05 . * * * \mathrm{P}<0.01$

Studies are listed in order of methodological quality 


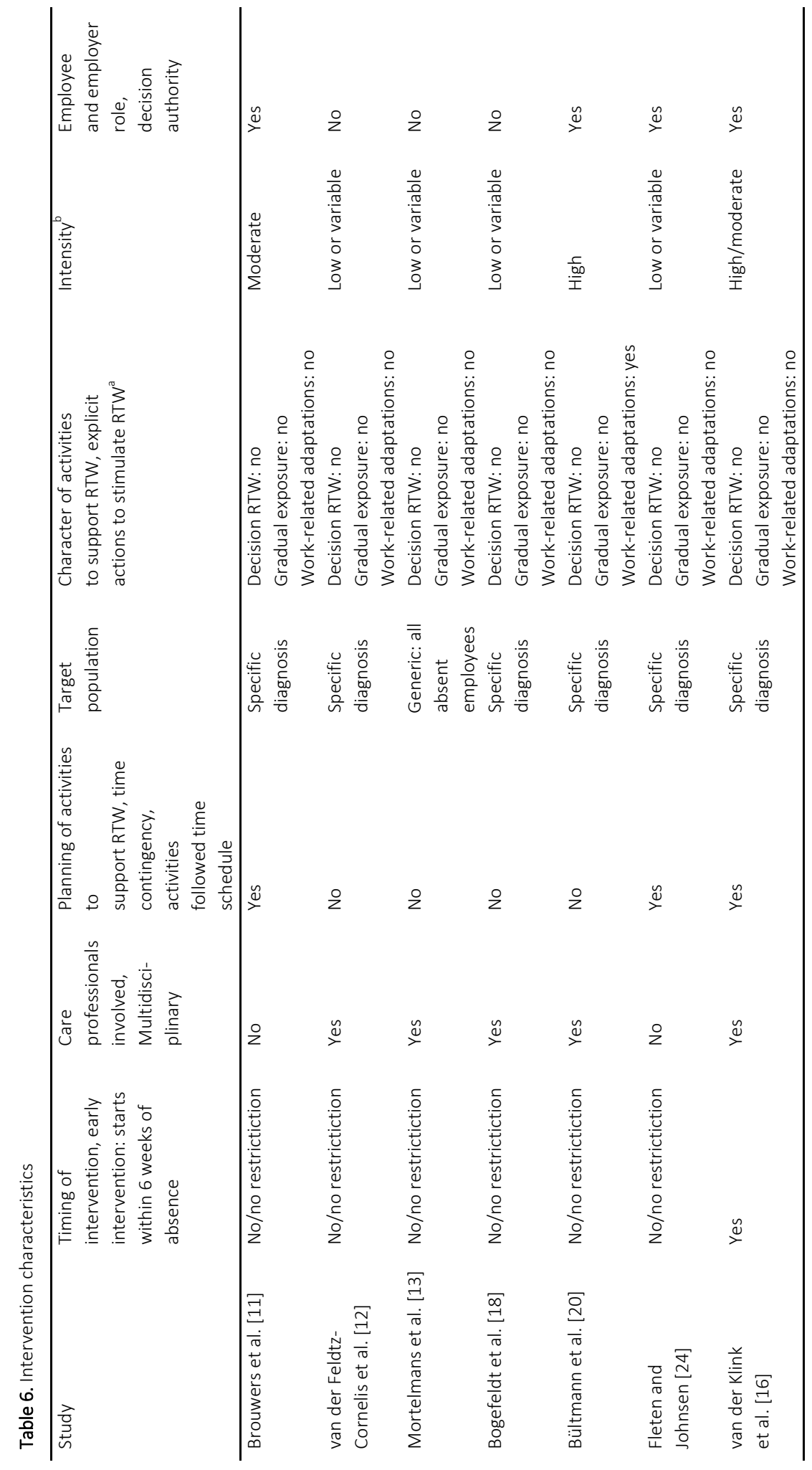




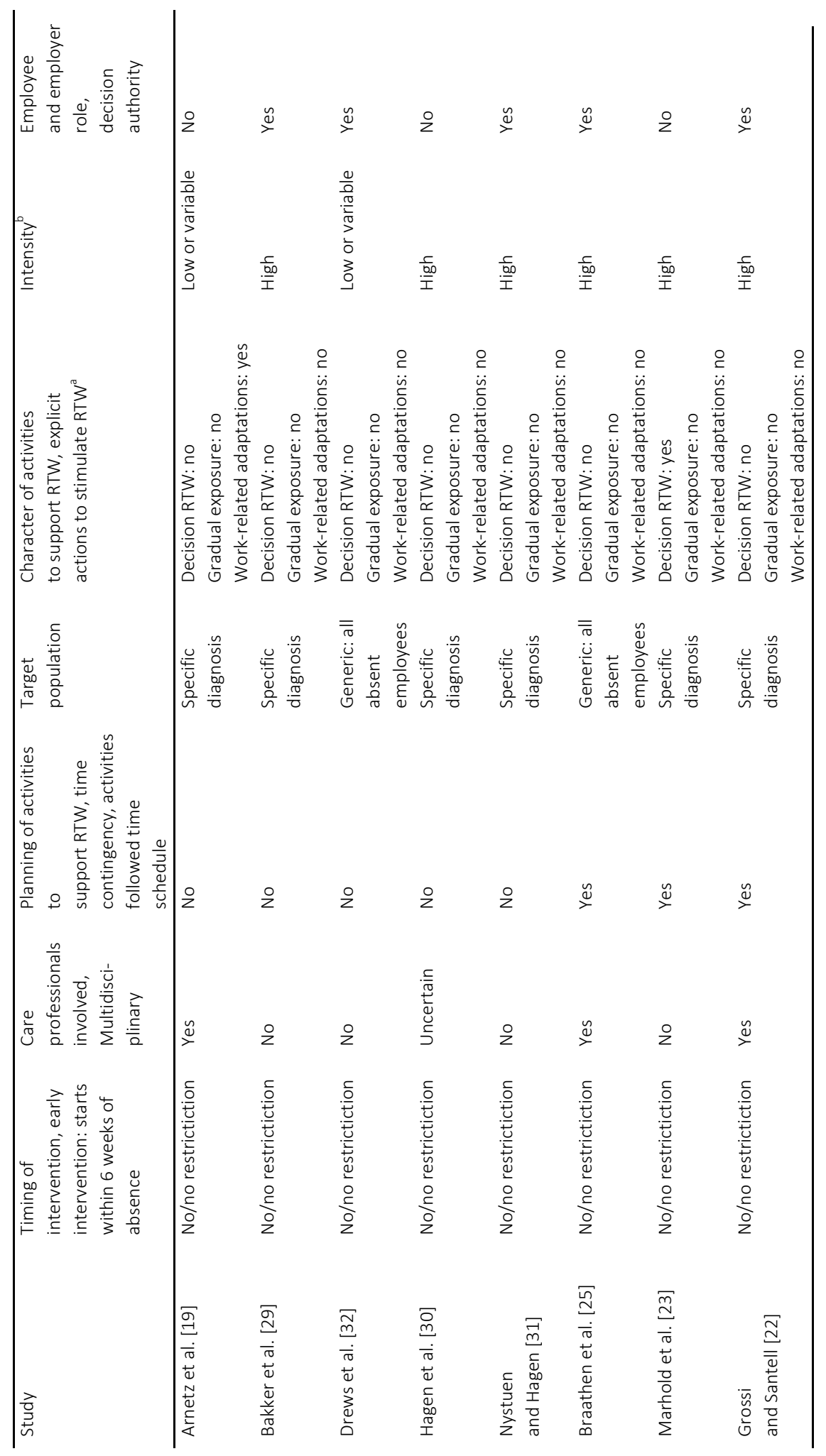




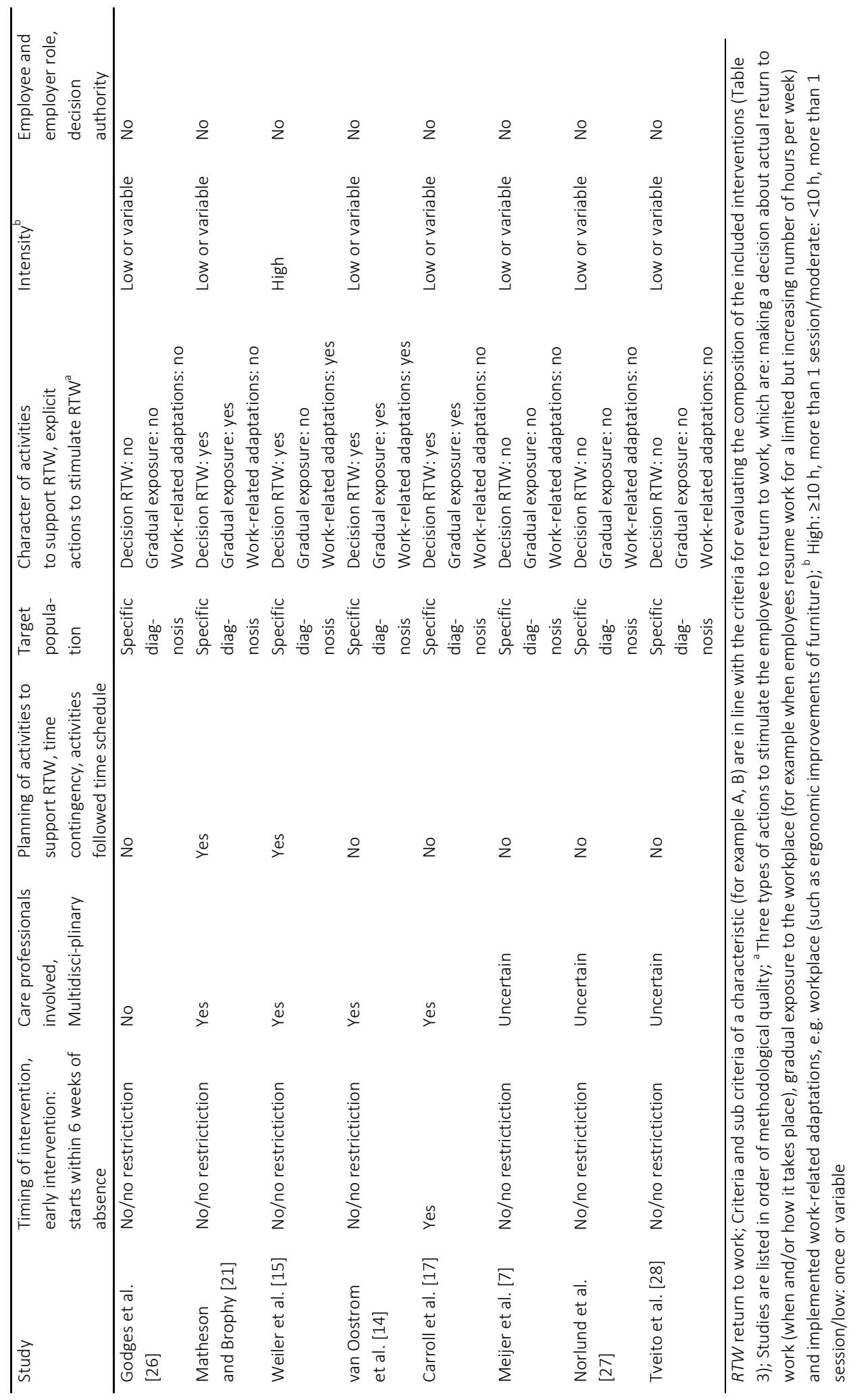


Based on Tables 5 and 6 we can describe characteristics of interventions that facilitate RTW:

Timing of intervention: early. Both interventions that started 'early' in the RTW process, namely in employees who were absent for 2 weeks [16] and 2-6 weeks of absence [17] facilitated RTW.

Care professionals involved: multidisciplinary. Multidisciplinary interventions included care providers and professionals from multiple disciplines such as general practitioners and physiotherapists [18] employer, case managers, occupational therapists/ergonomists [19], occupational physicians (OPs), occupational physiotherapists, chiropractors, psychologists and social workers having the role of case workers maintaining contact with the workplace and municipal case managers [20], OPs and psychiatrists [12].

Multidisciplinary interventions appeared to support RTW in physical complaints [14, 15, 17-21]. Two high quality studies showed that interventions that included contact with the employer/workplace improved RTW at 12 months follow up in employees with musculoskeletal complaints [19, 20]. The majority of the multidisciplinary interventions in psychological complaints were effective as well [12, 16]. However, one study did not show significant effects of multidisciplinary intervention in psychological complaints [22].

Planning of activities to support RTW: time contingent. In time contingent interventions, activities took place according to a pre-defined time schedule such as a treatment protocol prescribing the total number of sessions and the topics to be addressed in each session. Overall, evidence regarding the effect of time contingent interventions was inconsistent. Some interventions resulted in an earlier RTW [15, 16, $21,23,24]$, while others showed no significant effect on RTW [11, 22, 25]. Findings differed when subgroups are considered. Time contingent interventions were effective in physical complaints [15, 21, 23, 24]. Evidence was inconsistent about the effectiveness of time contingent interventions in psychological complaints. One intervention was effective [16], while two others showed no positive effects [11,22].

Target population: generic or specific. Evidence regarding the effect of interventions targeted at workers with specific diagnoses such as low back pain or adjustment disorders (specific interventions) was inconsistent. A considerable part of these interventions had a positive effect on RTW [12, 14-21, 23, 24, 26-28]. Other interventions targeted at employees with specific diagnoses had no (significant) effect on RTW [11, 22, 29-31].

Interventions targeted at all absent workers (generic interventions: irrespective of a specific diagnosis) showed no significant effect on RTW [13, 25, 32].

Character of activities to support RTW: interventions including explicit actions to stimulate the employee to RTW. Interventions including actions to stimulate the employee to RTW improved RTW outcomes. All these interventions were evaluated only in employees with physical complaints. For example, interventions including 
decision making on RTW or RTW as part of the intervention all facilitated RTW $[15,17$, $21,23]$. Similarly, interventions covering gradual exposure to the workplace, such as progressively augmented work tasks or partial RTW, had a positive effect on RTW [14, 17, 21]. Finally, interventions including the implementation of work related adaptations, e.g. ergonomic improvements of furniture facilitated RTW [14, 15, 19, 20].

Intensity: high, moderate or low. Evidence regarding high intensity interventions ( $\geq 10 \mathrm{~h}$ divided over multiple sessions) was inconsistent. Some of them facilitated RTW $[15,20,23]$, while others had no significant effect [22, 25, 29-31]. Evidence regarding interventions having a moderate ( $<10 \mathrm{~h}$ divided over multiple sessions) low (once) or variable intensity was also inconsistent (Tables 5 and 6).

Employee and employer role: decision authority. In nine studies, the employee and/or employer had decision authority with respect to activities to support medical recovery/RTW and/or actual RTW [11, 16, 20, 22, 24, 25, 29, 31, 32]. For example, the employee had the opportunity to comment on an RTW plan composed by professionals [20]. Often, only the employee and not the employer was given decision authority, for example to decide on (solutions on bottlenecks for) RTW $[11,16,20,29,31,32]$. Evidence regarding the effect of these interventions was inconsistent. Some facilitated RTW $[16,20,24]$ while in the majority of the studies no positive effect on RTW was found $[11,22,25,29,31,32]$.

\section{Conclusion}

The aim of this study was to detect and identify characteristics of RTW interventions that generally facilitate return to work (i.e. in multiple target populations and across interventions). Generally, we found two intervention characteristics that consistently facilitated RTW. Early interventions, that is, interventions initiated in the first 6 weeks of sickness absence, support RTW in multiple target groups. Early interventions appear to be scarce though. Multidisciplinary interventions appear effective to support RTW in physical complaints and in the majority of the studies in employees with psychological complaints. Particularly contact with the employer/workplace improves RTW at 12 months follow up in comparison with usual care for subjects with musculoskeletal complaints.

Moreover, we found two intervention characteristics that were effective in all physical complaints groups: time contingent and activating interventions. Time contingent interventions are effective in physical complaints. Evidence on effectiveness of this characteristic for psychological complaints is somewhat inconsistent. Activating interventions such as gradual RTW are relatively scarce and only found in studies about physical complaints.

Evidence is inconsistent about the effectiveness of interventions targeted at employees with specific diagnoses (although in more than half of the studies with this 
type of intervention, the results are positive), interventions of varying intensity and interventions covering employee and/or employer decision latitude.

The results of this review show that generic interventions, targeted at all employees on sick leave, irrespective of their diagnoses, show no positive effect.

\section{Discussion}

In this study, we focused on characteristics of RTW interventions that generally were effective. The wide range of target populations and interventions may have diluted the more specific findings though. Therefore, we assessed the effectiveness of the intervention characteristics in physical- and psychological complaints separately. It appeared that early and multidisciplinary interventions were effective in both target groups, while for example time contingent interventions were particularly effective for employees with physical complaints.

Our findings showing the general effectiveness of multidisciplinary intervention suggest the importance of cooperation between care professionals and/or case managers and/or employers to for instance align the medical recovery- and RTW process. Particularly contact with the employer/workplace resulted in improved RTW after 12 months follow up $[19,20]$. These interventions may help to find mutually desired work adaptations, supporting the employee's long-term employability. Second, we found that early intervention stimulates early RTW. Researchers found that early intervention has some other effects than early RTW as well. Early intervention was associated with less repeated sickness absence [33]. At the same time, (early return to) work can be beneficial for the employee's health [34], hence these effects somehow benefit employees and employers alike.

Additionally, we found that there were more interventions for physical complaints than for psychological complaints. Interestingly, interventions in physical complaints were more often effective than those in psychological complaints. This for example applies to time contingent interventions and might be explained by the following. The course of psychological complaints (such as stress-related disorders) might be more instable than that of physical complaints such as low back pain. Therefore, it might be relatively difficult for people with psychological complaints to follow a pre-defined time schedule for intervention. Also, professionals and employers might be less inclined to do so. Further, it might be that RTW professionals and scientists tend to choose physical complaints as a target population to increase their chances of success.

Nevertheless, our study results suggest that early and multidisciplinary interventions are generally effective and should be included in all interventions for RTW. 


\section{Methodological reflections}

This study has some strengths. We performed a comprehensive methodological quality assessment and description of steps that were taken. These features increased the study's reliability and validity.

Most previous systematic reviews [7, 17, 27, 28] focused on one specific target population such as back pain. We applied our taxonomy of intervention characteristics to multiple target populations including psychological complaints and musculoskeletal complaints. Our study results regarding early and multidisciplinary intervention hold for multiple target populations. This enhanced our current knowledge of strategies to support RTW.

However, our study also has some limitations. It was not possible to perform a meta-analysis due to heterogeneity of the outcome measure (RTW) as defined in the included studies.

Our study results showed the effectiveness of interventions initiated in the first 6 weeks of the RTW process and multidisciplinary interventions. This conclusion is based on only two early interventions that we included in our review. This may be insufficient to consider the study results to be a theoretical framework. However, our results may indicate some successful strategies to support RTW.

Surprisingly, we found that activating interventions (for example those including a decision about RTW) support RTW in employees with physical complaints, while we did not find such interventions for employees with psychological complaints. Possibly, interventions for employees with psychological complaints tend to activate in other ways than measured in this study (that is: deciding about RTW, gradual exposure to the workplace and/or implemented workplace adaptations). For example, interventions may primarily focus on regaining feelings of control and support subjects' own responsibility to identify and solve bottlenecks for participation $[11,16]$.

Our taxonomy may not have detail enough to inform professionals in RTW such as OPs about the exact content of appropriate interventions (for example the content of contacts with the employer). To the authors' knowledge though, this is the first study that assessed the effect of intervention characteristics on RTW in a systematic way, and may as such be a good starting point for RTW professionals.

\section{Implications for practice and research}

This review focused on intervention characteristics that facilitate RTW. Our findings have implications for practice and research.

In the first place, the results showed the effectiveness of early interventions and multidisciplinary interventions including contact with the employer. Activating interventions were effective, but only found in physical complaints. Early-, multidisci- 
plinary- and activating interventions should be applied more often, especially in psychological complaints. To start early in the RTW process, general practitioners and OPs need to refer employees and employers to these interventions within the first 6 weeks of the employee's absence. Interventions should incorporate interdisciplinary cooperation between professionals in health care and contact with the employer. A matrix structure may support this cooperation. It is essential that professionals have enough resources such as time for interdisciplinary contacts. In the Netherlands, the employee and employer have a legal responsibility to cooperate with each other in order to support the employee's RTW [35]. Researchers and policy makers could study the Dutch situation to find tools for involving the employer in employee RTW. Interventions and other care products should empower both the employee and the employer by incorporating explicit measures to stimulate them to realise RTW.

To know the exact content of successful interventions to support RTW, future studies may focus on detailing our taxonomy of intervention characteristics. Researchers may particularly focus on further detailing the effective intervention characteristics such as appropriate cut-off scores for early intervention and the exact content or intensity of multidisciplinary contact between care providers and employers.

In addition, because we found quite some inconsistent results (e.g. regarding the intensity of the intervention or the involvement of the employer), future research should focus on multifactorial analyses such as meta-analyses. This may help to study which individual or combined intervention characteristics facilitate RTW. Researchers should define RTW precisely and include this single definition as an outcome in any study to increase possibilities for meta-analyses.

In this study, we classified intervention characteristics. Researchers can use our taxonomy to classify the characteristics of RTW interventions in future systematic reviews. This would enable comparison of study results and strengthen the evidence about intervention characteristics that support RTW.

Finally, we found very few early interventions, despite their wide use by professionals (e.g. by many OPs and employers). The gap between research and practice appears to be large. To support evidence-based practice, we advise more cooperation between professionals in practice and research, for example in formulating research questions. 


\section{References}

1. Black C. Working for a healthier tomorrow. TSO. 2008. http://www.dwp.gov.uk/docs/hwwb-working-fora-healthier-tomorrow.pdf. Accessed 9 Dec 2011.

2. Ektor-Andersen J, Ingvarsson E, Kullendorff M, Orbaek P. High cost-benefit of early team-based biomedical and cognitive behaviour intervention for long-term pain-related sickness absence. J Rehabil Med. 2008;40:1-8.

3. Adams A, Ellis T, Stanish WD, Sullivan MJL. Psychosocial factors related to return to work following rehabilitation of whiplash injuries. J Occup Rehabil. 2007;17:305-15.

4. Ouellette V, Badii M, Lockhart K, Yassi A. Worker satisfaction with a workplace injury prevention and return-to-work program in a large Canadian hospital: the importance of an integrated approach. Work. 2007;28:175-81.

5. Elders LAM, van der Beek AJ, Burdorf A. Return to work after sickness absence due to back disorders. a systematic review on intervention strategies. Int Arch Occup Environ Health. 2000; 73:339-48.

6. Franche R-L, Cullen K, Clarke J, Irvin E, Sinclair S, Frank J, et al. Workplace-based return-to-work interventions: a systematic review of the quantitative literature. J Occup Rehabil. 2005;15: 607-31.

7. Meijer EM, Sluiter JK, Frings-Dresen MHW. Evaluation of effective return-to-work treatment programs for sick-listed patients with non-specific musculoskeletal complaints: a systematic review. Int Arch Occup Environ Health. 2005;78:523-32.

8. McMaster University. Faculty of Health Sciences. Quality assessment tool for quantitative studies. In: Effective public health practice project. 2009. http://www.ephpp.ca/images/PDF/ QATool.pdf. Accessed 9 Dec 2011.

9. Cochrane. Formulier Vc voor het beoordelen van een systematische review van observationeel onderzoek [Form Vc for the assessment of a systematic review of observational research]. In: Dutch Cochrane Centre. [date unknown] http://www.cochrane.nl/Files/documents/Checklists/SR-Obs.pdf. Accessed 9 Dec 2011.

10. Armijo-Olivo S, Stiles CR, Hagen NA, Biondo PD, Cummings GC. Assessment of study quality for systematic reviews: a comparison of the Cochrane collaboration risk of bias tool and the effective public health practice project. Quality assessment tool: methodological research. J Eval Clin Pract. 2010. doi: 10.1111/j.1365-2753.2010.01516.x

11. Brouwers EPM, Tiemens BG, Terluin B, Verhaak PFM. Effectiveness of an intervention to reduce sickness absence in patients with emotional distress or minor mental disorders: a randomised controlled effectiveness trial. Gen Hospital Psychiatry. 2006; 28:223-9.

12. van der Feldtz-Cornelis C, Hoedeman R, de Jong FJ, Meeuwissen JAC, Drewes HW, van der Laa NC, et al. Faster return to work after psychiatric consultation for sicklisted employees with common mental disorders compared to care as usual. A randomized clinical trial. Neuropsych Dis Treat. 2010;6:375-85.

13. Mortelmans AK, Donceel P, Lahaye D, Bulterys S. Does enhanced information exchange between social insurance physicians and occupational physicians improve patient work resumption? A controlled intervention study. Occup Environ Med. 2006;63:495-502.

14. van Oostrom SH, Driessen MT, de Vet HCW, Franche RL, Schonstein E, Loisel P, et al. Workplace interventions for preventing work disability (Review). Cochrane Library. 2009;. doi: 10.1002/14651858.CD006955.pub2.

15. Weiler SW, Foeh KP, van Mark A, Toussaint R, Sonntag N, Gaessler A, et al. Outpatient rehabilitation of workers with musculoskeletal disorders using structured workplace description. Int Arch Occup Environ Health. 2009;82:427-34.

16. van der Klink, Blonk RWB, Schene AH, van Dijk FJH. Reducing long term sickness absence by an activating intervention in adjustment disorders: a cluster randomised controlled design. J Occup Environ Med. 2003;60:429-37. 
17. Carroll C, Rick J, Pilgrim H, Cameron J, Hillage J. Workplace involvement improves return to work rates among employees with back pain on long-term sick leave: a systematic review of the effectiveness and cost-effectiveness of interventions. Disabil Rehabil. 2010;32:607-21.

18. Bogefeldt J, Grunnesjö M, Svärdsudd K, Blomberg S. Sick leave reductions from a comprehensive manual therapy programme for low back pain: the Gotland low back pain study. Clin Rehabil. 2008;22:529-41.

19. Arnetz BB, Sjörgen B, Rydéhn B, Meisel B. Early workplace intervention for employees with musculoskeletal-related absenteeism: a prospective controlled intervention study. J Occup Environ Res. 2003;45:499-506.

20. Bültmann U, Sherson D, Olsen J, Lysbeck Hansen C, Lund T, Kilsgaard J. Coordinated and tailored work rehabilitation: a randomised controlled trial with economic evaluation undertaken with workers on sick leave due to musculoskeletal disorders. J Occup Rehabil. 2009;19:81-93.

21. Matheson LN, Brophy RG. Aggressive early intervention after occupational back injury: some preliminary observations. J Occup Rehabil. 1997;7:107-17.

22. Grossi G, Santell B. Quasi-experimental evaluation of a stress management programme for female county and municipal employees on long-term sick leave due to work-related psychological complaints. J Rehabil Med. 2009;41:632-8.

23. Marhold C, Linton SJ, Melin L. A cognitive-behavioral return-to-work program: effects on pain patients with a history of longterm versus short-term sick leave. Pain. 2001;91:155-63.

24. Fleten $\mathrm{N}$, Johnsen R. Reducing sick leave by minimal postal intervention: a randomised, controlled intervention study. J Occup Environ Med. 2006;63:676-82.

25. Braathen TN, Veiersted KB, Heggenes J. Improved work ability and return to work following vocational multidisciplinary rehabilitation of subjects on long-term sick leave. J Rehabil Med. 2007;39:493-9.

26. Godges JJ, Anger MA, Zimmerman G, Delitto A. Effects of education on return-to-work status for people with fear-avoidance beliefs and acute low back pain. Phys Ther. 2008;88:231-9.

27. Norlund A, Ropponen A, Alexanderson K. Multidisciplinary interventions: review of studies of return to work after rehabilitation for low back pain. J Rehabil Med. 2009;41:115-21.

28. Tveito $T H$, Hysing M, Eriksen HR. Low back pain interventions at the workplace: a systematic literature review. Occup Med. 2004;54:3-13.

29. Bakker IM, Terluin B, van Marwijk HWJ, van der Windt DAWM, Rijmen F, van Mechelen W, et al. A clusterrandomised trial evaluating an intervention for patients with stress-related mental disorders and sick leave in primary care. PLoS Clin Trials. 2007; . doi:10.1371/0020026.

30. Hagen EM, $\varnothing$ delien $\mathrm{KH}$, Lie SA, Eriksen HR. Adding a physical exercise programme to brief intervention for low back pain patients did not increase return to work. Scand J Public Health. 2010;38:731-8.

31. Nystuen P, Hagen KB. Solution-focused intervention for sick listed employees with psychological problems or muscle skeletal pain: a randomised controlled trial. BMC Public Health. 2006;16:69.

32. Drews B, Nielsen CV, Rasmussen MS, Hjort J, Bonde JP. Improving motivation and goal-setting for return to work in a population on sick leave: a controlled study. Scand J Public Health. 2007;35:86-94.

33. Øyeflaten I, Lie Stein A, Ihlebaeck C, Eriksen HR. Complex patterns for shifting between work and benefits during a 5-year follow-up after work-related rehabilitation!-Need for differentiated interventions? Poster session presented at: EUPHA, Annual Conference of the European Public Health Association; 2010 Nov 10-13; Amsterdam, The Netherlands.

34. Waddell G, Burton AK. Is work good for your health and well-being? TSO. 2006 http://www.kendallburton.com/Library/ downloadpdfs.html. Accessed 9 Dec 2011.

35. Ministerie van Sociale Zaken en Werkgelegenheid. Ziekteverzuim van het werk. [Sickness absence] Rijksoverheid. [date unknown]. http://www.rijksoverheid.nl/onderwerpen/ziekteverzuimvan-het-werk. Accessed 9 Dec 2011. 


\section{CHAPTER 3}

Environmental and personal factors that support early return-to- work:

a qualitative study using the ICF as a framework 


\section{Abstract}

Background: Occupational health professionals such as occupational physicians (OPs) increasingly understand that in addition to health improvement, environmental factors (such as work adaptations) and personal factors (such as an employee's attitude towards return-to-work (RTW)) may stimulate employees on sick leave to return to work early. To target their professional interventions more specifically according to these factors, occupational health professionals need further insight into environmental and personal factors that stimulate RTW.

Objective: The objectives of this study are (1) to identify which and how environmental and personal factors support early RTW, and (2) to examine whether the International Classification of Functioning, Disability and Health (ICF) can be used to describe these factors.

Methods: We performed interviews with 14 employees, 15 employers and 4 OPs from multiple organisations with varying organisational sizes and types of industry such as healthcare and education. We used a qualitative data analysis partially based on the Qualitative Analysis Guide of Leuven.

Results: The following environmental factors were found to support early RTW: 'social support from relatives', 'belief that work stimulates health', 'adequate cooperation between stakeholders in RTW' (e.g. employees, employers and OPs) and 'the employers' communicative skills'. One personal factor stimulated RTW: 'positive perception of the working situation' (e.g. enjoyment of work). Most factors stimulated RTW directly. In addition, adequate treatment and social support stimulated medical recovery. Environmental factors can either fully (social support, belief that RTW stimulates health), partially (effective cooperation), or not (employers' communicative skills) be described using ICF codes. The personal factor could not be classified because the ICF does not contain codes for personal factors.

Conclusions: RTW interventions should aim at the environmental and personal factors mentioned above. Professionals can use the ICF to describe most environmental factors. 


\section{Introduction}

Research has shown that employees on sickness absence benefit from the positive health effects of return- to-work (RTW) [1]. At the same time, early RTW implies lower financial costs for employers and governments.

Occupational health professionals such as occupational physicians (OPs) increasingly understand that in addition to health improvement, environmental factors (such as work adaptations) and personal factors (such as an employee's attitude towards RTW [2]) may stimulate employees on sick leave to return to work early. To target their professional interventions more specifically according to these factors, occupational health professionals need further insight into environmental and personal factors that stimulate RTW. This study aims to provide an overview of these environmental and personal factors.

The literature on this topic mainly describes the bottlenecks that delay and inhibit RTW. These bottlenecks can be translated into factors that stimulate RTW. Three factors described in the literature are environmental. First, 'social support by supervisors or colleagues' may influence RTW [3-6]. Social support and social status gained through working and through contact with colleagues appears to motivate employees to resume work [3-6]. Feeling needed at work and being part of a social context appear to be important as well. Further, social support by family members may be of importance [7]. Second, having a positive attitude towards working when not (yet) feeling healthy, facilitates RTW [6]. Finally, employees in particular believe that RTW is influenced by the 'timeliness and adequacy of professional support'. The literature describes several sorts of untimely and inadequate professional support that inhibit RTW including delays in diagnosis or treatment, delays in support from the social insurance $[2,8]$ and a lack of satisfying work modifications proposed by employers $[4,6,9]$, resulting in failure to modify work or conflicts between employees and employers [2,4,6,9-14]. Hazardous physical working conditions are also associated with longer absences. This suggests the importance of work modifications [15]. Similarly, organisational RTW support and especially the availability of RTW programmes may help employees to return to work earlier [16]. Finally, monodisciplinary curative care, without explicit measures to support RTW (such as agreements between the general practitioner and OP about the medical diagnosis) may indicate sub-optimal RTW strategies $[17,18]$. In summary, the bottlenecks show that introducing more timely and adequate support appears to stimulate RTW.

The literature also describes three personal factors. First, a reduction of employees' avoidant coping style, a passive strategy to cope with bottlenecks in RTW, appears to stimulate their RTW [19]. Second, the employees' perception of the time required to return to work was shown to be an important prognostic factor of actual RTW [20]. Finally, RTW rates appear to be higher among employees with higher educational levels [4]. 
However, for various reasons these studies do not provide occupational health professionals with a clear overview of which factors usually influence RTW and, therefore, require intervention. Most studies were performed in very specific populations such as a group of employees after they had had a lower limb amputation [4]. Many studies have only included one group of stakeholders (mostly employees), meaning that they only examined RTW from one perspective. It is likely, however, that according to the employers and OPs different factors influence RTW than according to the employees. For example, employees may find it important that employers propose satisfying work modifications, whereas employers may focus on the employees' willingness to accept modified work.

Moreover, the studies do not give the occupational health professionals insight into how the factors support RTW. For example, adequate curative treatment (an environmental factor) may support medical recovery, and in turn may stimulate RTW. Other factors, such as work modifications, may even enable employees to return to work immediately. Such knowledge about the working mechanisms of the different factors is relevant to occupational health professionals who aim to develop interventions to resolve RTW issues. In summary, there is a need for qualitative and indepth knowledge about which and how environmental and personal factors influence RTW.

In addition to their lack of evidence-based knowledge about which and how the different factors stimulate RTW, occupational health professionals do not yet use a framework to describe the environmental and personal factors that need professional intervention. Frameworks do, however, exist. The Occupational Competence Model, for example, has already been applied to specific populations of formerly unemployed sickness absentees [21] and employees on sick leave with musculoskeletal disorders who participated in rehabilitation [22]. Interestingly, the widely known and acknowledged International Classification of Functioning, Disability and Health (ICF), covers a classification system to identify factors that may influence participation in, for example, work (Fig. 1) and to tailor treatment according to these factors [23]. 


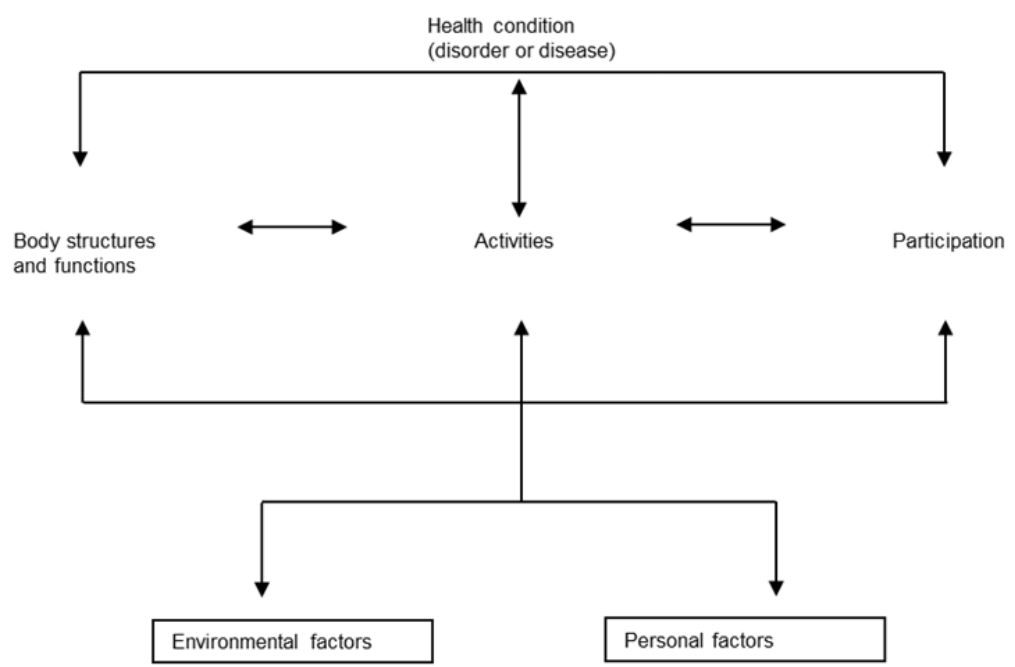

Figure 1. The International Classification of Functioning, Disability and Health [39]

The ICF helps professionals such as physiotherapists to recognise environmental factors such as the type of work employees want to resume (e.g. physically demanding work) and personal factors (e.g. coping skills that may influence employees' functioning) and to tailor treatment exercises according to these factors. As such, the ICF can serve as a framework for RTW interventions in occupational healthcare. ICF- based RTW interventions can also be standardised, and create a lower dependence on the quality provided by individual professionals. Hence, the ICF can help to ensure and improve the quality of professional support. However, although the ICF also includes environmental and personal factors, it is still used mostly in the clinical sector, for example, to describe functioning in patients [24]. Researchers have already suggested using the ICF to guide ergonomic intervention in occupational rehabilitation of workers with musculoskeletal disease [25] and in job placement [26]. Also, the ICF or ICF Core Sets can be used to describe environmental and/or personal factors in specific target populations such as clients with breast cancer [27] or mental disorders [28, 29], or in vocational rehabilitation clients $[30,31]$. However, to the authors' knowledge, no studies have yet been conducted about whether the ICF is useful for describing environmental and personal factors that stimulate RTW in general (i.e. in a population of employees on sickness absence with diverse health complaints). This knowledge is needed to determine the usefulness of the ICF for RTW practice in general. In case the ICF is found to be useful for RTW practice, standardised ICF-based interventions can be developed that may ensure a minimum quality of professional support.

Considering the above, professionals need combined evidence-based knowledge of the environmental and personal factors that stimulate RTW as well as knowledge about 
the usefulness of the ICF for describing these factors. The aims were to study (1) which environmental and personal factors support employees' RTW and how they support RTW, and (2) to examine whether professionals can use the ICF to describe these factors. To answer these questions, we conducted in-depth interviews with three RTW stakeholder groups: employees, employers and OPs. Our study is unique because it combines an in-depth and multi-stakeholder qualitative study of the factors that influence RTW with an ICF classification of these factors in a general population of sicklisted employees. This approach supports our understanding of the interactions between various stakeholders in the RTW process. At the same time, it provides insight into the degree to which the ICF applies to this complex reality. This may help professionals to develop more effective (and possibly ICF-based) interventions to stimulate early RTW. Evidence on the usefulness of the ICF for RTW may also contribute to its further development and validation. Ultimately, these insights may help occupational professionals to improve the RTW process for all employees on sick leave.

\section{Methodology}

\section{Design, population and procedure}

This qualitative study was based on a design including interviews with two samples. The first sample included employees, employers and OPs. The analysis of data from the first round provided an overview of the factors that may facilitate RTW. Based on the results, we composed and recruited a second sample consisting of employees and employers. By asking more specific questions in this second round, we aimed to gather more in-depth knowledge about the factors that influence RTW. We stopped interviewing in the second round when data saturation was achieved.

Participants were recruited by means of purposive and snowball sampling. Employees and employers were chosen purposefully to represent the general working population. In line with this, we selected a sample of employees and employers that covered variation in organisational size and industry as well as the employees' age, gender and health complaints. The employers and OPs were contacted with the help of the telephone book on the internet (for searching contact information of the employers an OPs) [32]. We also contacted some OPs through the authors' professional networks. However, this procedure did not yield any employee participants. Therefore, at the end of their interviews, we asked the employers and OPs to provide referrals to employees. Further, we also contacted psychologists and physiotherapists through their professional associations' websites and asked them for referrals to employees. Finally, we recruited an employee by means of the first author's personal network. We selected employees, employers and OPs who met the following inclusion criteria: 
- Employees who had been absent for more than 42 days and less than 2 years (long-term sick leave) or had experienced long-term sick leave and had resumed work less than one year before the interview;

- Employers who represented the organisations' RTW policy and supported absent employees to resume work (e.g. by maintaining contact). Mostly human resource officers and managers (HR professionals) met this criterion;

- OPs who supported individual employees on sickness absence to return to work.

With respect to the employers, we studied the actions of both the HR professionals who were interviewed and the supervisors they sometimes talked about. We did not interview supervisors themselves, because they often have experience with only a few absent employees. Table 1 provides an overview of all 34 participants. Two OPs and three HR professionals were from the same organisations/industries as the employees we interviewed.

Table 1. Characteristics of the study participants

\begin{tabular}{|c|c|c|c|c|c|}
\hline \multirow[t]{2}{*}{ Characteristic } & \multicolumn{3}{|c|}{ Sample 1 Stakeholder (number) } & \multicolumn{2}{|c|}{ Sample 2 Stakeholder (number) } \\
\hline & $\begin{array}{l}\text { Employee (6) } \\
(\# 1 \text { to \#6) }\end{array}$ & $\begin{array}{l}\text { HR professional (7) } \\
\text { (\#1 to \#7) }\end{array}$ & $\begin{array}{l}\text { Occupational } \\
\text { physician (5) } \\
\text { (\#1 to \#5) }\end{array}$ & $\begin{array}{l}\text { Employee (8) } \\
\text { (\#7 to \#14) }\end{array}$ & $\begin{array}{l}\text { HR professional (8) } \\
\text { (\#8 to \#15) }\end{array}$ \\
\hline $\begin{array}{l}\text { Health } \\
\text { complaints }\end{array}$ & \multicolumn{3}{|l|}{$\begin{array}{l}\text { Psychological (3) } \\
\text { / Physical (3) }\end{array}$} & \multicolumn{2}{|l|}{$\begin{array}{l}\text { Psychological (3) } \\
\text { / } \\
\text { Physical (2) / } \\
\text { Combination (3) }\end{array}$} \\
\hline Age in years & \multicolumn{3}{|l|}{$<45(1) / \geq 45(5)$} & \multicolumn{2}{|l|}{$<45(4) / \geq 45(4)$} \\
\hline Gender & $\begin{array}{l}\text { Male (5) / } \\
\text { Female (1) }\end{array}$ & Male (3) / Female (4) & $\begin{array}{l}\text { Male (4) / } \\
\text { Female (1) }\end{array}$ & $\begin{array}{l}\text { Male (4) / } \\
\text { Female (4) }\end{array}$ & Male (4) / Female (4) \\
\hline $\begin{array}{l}\text { Organisational } \\
\text { size }\end{array}$ & \multicolumn{2}{|c|}{$\begin{array}{l}20-150(1) />15020-150(1) />150(6) \\
(5)\end{array}$} & & $\begin{array}{l}20-150(2) / \\
>150(6)\end{array}$ & $20-150(1) />150(7)$ \\
\hline Industry & $\begin{array}{l}\text { Information } \\
\text { technology or } \\
\text { technical (4) / } \\
\text { Human } \\
\text { resources (1) / } \\
\text { Commercial (1) }\end{array}$ & $\begin{array}{l}\text { Social security (1) / } \\
\text { Learning and } \\
\text { development (1) / } \\
\text { Commercial (5) }\end{array}$ & & $\begin{array}{l}\text { Production } \\
\text { industry (2) / } \\
\text { Healthcare (2) / } \\
\text { Education (1) / } \\
\text { Commercial (3) }\end{array}$ & $\begin{array}{l}\text { Information and } \\
\text { communication } \\
\text { Technical (4) / } \\
\text { Healthcare (2) / } \\
\text { Education (1) / } \\
\text { Commercial (1) }\end{array}$ \\
\hline Profession & & $\begin{array}{l}\text { HR Officer (4) / HR } \\
\text { Manager (2) / Sick } \\
\text { leave coordinator (1) }\end{array}$ & & & $\begin{array}{l}\text { HR Officer (4) / HR } \\
\text { Manager (3) / } \\
\text { Director occupational } \\
\text { healthcare (1) }\end{array}$ \\
\hline
\end{tabular}


In order to help the reader understand and interpret the interview results, we provide some information about the Dutch sickness absence and disability schemes. In the nineties, relatively many Dutch citizens were on a disability pension [33]. In line with the social model of disability, and to benefit individual and collective well-being as well as economic prosperity [34,35], the Dutch government stimulated sick employees to participate according to their ability. The government also developed extensive legislation that made the absent employees and their employers responsible for RTW. The Improved Gatekeeper Act, which was introduced in 2002, describes obligatory actions for both employees and employers, such as composing an action plan for RTW and to discuss progress in the RTW process. Employees are compensated by their employers for at least $70 \%$ of their income during the first two years of their absence [36]. Most employers pay $100 \%$ of the employee's income during the first year of absence. The employers usually pay for the services of an OP. If there is no progress in the RTW process, both the employee and the employer can ask the social insurance office for a second opinion about their own activities to support RTW and about possibilities for employee to resume work. After two years, the employer usually is no longer involved in the employees' RTW process, and the social insurance office takes over the responsibility of supporting the employee to return to work [36]. In summary, there is a financial and legal incentive for the employer to help the employee to return to work during two years of sick leave.

\section{Data collection and analyses}

The open-ended interviews took place at the participants' homes or workplaces. At the request of a number of OPs, they were interviewed by telephone. All interviews were semi-structured. They were approximately two hours in length. One interview with an HR professional was only 30 minutes, because of conflicting appointments in the interviewee's agenda. The interview scheme for the first sample consisted of topics and subtopics about the bottlenecks that the participants felt inhibited employees' early RTW. We assumed that resolving these bottlenecks would stimulate RTW. The topic list for the interviews with employees and HR professionals included the activities of the two parties to support RTW and their contact with other stakeholders (care professionals, OPs, the social insurance agency, family and friends). The latter topic, contact with family and friends, applied to the employees only. In the interviews with the OPs, the following topics were covered: the support that employees and HR professionals or supervisors needed from the OP, the attitudes and behaviour of employees, HR professionals and supervisors towards the OPs, the employees', supervisors' and HR professionals' satisfaction with the OPs, the OPs contact with curative care professionals and the OPs experience with the employees' family and 
friends. In the first sample, the interviewer prompted the participants to indicate which bottlenecks they experienced in RTW by asking questions: What happened? Why do you think this happened? What did you think of this? How did you react? Was this successful? How did the other stakeholders react to your response? The scheme for the second sample consisted of general questions about the bottlenecks in early RTW: To what extent are/were you able to determine when and how RTW takes/took place? To what extent are/were you inhibited by others to resume work/support the employee to resume work? The scheme also included subtopics based on insights that resulted from analysing data from the first sample. More specific questions were asked here regarding, for example, whether meetings had been arranged and which issues were discussed during these meetings. Prompting increased the richness of the information. All interviews were conducted in Dutch and the questions mentioned above are English translations of the original questions. During three interviews, the interviewer made notes. The other interviews were tape- recorded with the participants' consent. We stopped interviewing new participants once saturation had been achieved.

The recorded interviews were transcribed verbatim and analysed by means of six steps partially based on the Qualitative Analysis Guide of Leuven (QUAGOL) [37]: (1) (re)reading the interviews, (2) making narrative interview reports (i.e. a brief abstract of the key storylines of each interview), (3) translating each narrative interview report into a list of conceptual themes and subthemes and making one overall list of themes for all interviews together, (4) fitting test of the conceptual themes (testing the appropriateness of the different themes for the separate interviews), (5) making constant comparisons to refine themes (forward-backwards movement between within-case and across-case analysis), and (6) defining final themes and describing the results. In step 3, we searched for bottlenecks in RTW and translated those into suggestions to stimulate RTW (themes). In step 5, we studied the perspectives of different stakeholders (employees, HR professionals and OPs) on similar themes. We aimed to provide a rich description of the dataset. The first author (NH) performed the analysis. To enhance peer validity, NH discussed all themes with the other authors (IH and FN). When there were disagreements about a theme, $\mathrm{NH}$ and $\mathrm{IH}$ analysed this theme together.

Afterwards, each theme was compared with and, if possible, described using ICF coding [23]. To enhance peer validity of this part of the analysis, the authors consulted a scientist (YH) in the field of the ICF. YH checked the appropriateness of all the ICF codes chosen. 


\section{Results}

\section{Factors that may support RTW}

Table 2 shows four environmental factors that emerged from the analysis of the interview data: 1) 'social support from relatives'; 2) 'employees' and HR professionals' belief that RTW supports medical recovery'; 3) 'effective cooperation between employees, HR professionals and supervisors, curative professionals, OPs and the social insurance office regarding RTW'; and 4) 'supervisors' communicative skills'. An example of the third factor is agreement between employees on the one hand and HR professionals and supervisors on the other hand regarding bottlenecks and the desired intervention. We also found one personal factor related to 'employees' positive perception of the situation'. Below, we describe both types of factors by focusing on bottlenecks in RTW and translating these into suggestions to support RTW.

Table 2. Factors that support employees' early return-to-work

\begin{tabular}{|c|c|c|}
\hline Environmental factors & Factors may stimulate & Factors in ICF coding \\
\hline $\begin{array}{l}\text { 1. Social support by relatives } \\
\text { (such as partner) }\end{array}$ & Medical recovery, RTW & $\begin{array}{l}\text { 'e3 support and relationships' and } \\
\text { especially 'e310 immediate family' }\end{array}$ \\
\hline $\begin{array}{l}\text { 2. Belief that RTW may contribute to } \\
\text { medical recovery }\end{array}$ & RTW & $\begin{array}{l}\text { 'e } 4 \text { attitudes' and especially 'e } 410 \\
\text { individual attitudes of immediate family } \\
\text { members' }\end{array}$ \\
\hline $\begin{array}{l}\text { 3. Effective cooperation between } \\
\text { employees and supervisors, HR } \\
\text { professionals on the one hand and } \\
\text { (health and occupational) professionals } \\
\text { on the other to realise RTW: } \\
\text { - On the one hand, employees and } \\
\text { supervisors, HR professionals need to: }\end{array}$ & & $x$ \\
\hline $\begin{array}{l}\text { * Agree on bottlenecks and desired } \\
\text { intervention } \\
\text { * Have success in modifying work } \\
\text { * Make an adequate appeal to OP and } \\
\text { social insurance office for support } \\
\text { - On the other hand, professionals need } \\
\text { to provide/ensure: }\end{array}$ & RTW & $\begin{array}{l}\text { 'e5 services, systems and policies', 'e590 } \\
\text { labour and employment services, systems } \\
\text { and policies' and especially 'e5900 labour } \\
\text { and employment services' }\end{array}$ \\
\hline * Timely diagnosis & RTW & 'e5 services, systems and policies', 'e580 \\
\hline${ }^{*}$ Adequate curative treatment & Medical recovery, RTW & $\begin{array}{l}\text { health services, systems and policies' and } \\
\text { especially 'e5800 health services' }\end{array}$ \\
\hline $\begin{array}{l}\text { * Adequate OP role taking (for example } \\
\text { not taking over the employers' } \\
\text { responsibilities) }\end{array}$ & $\begin{array}{l}\text { RTW (employees and } \\
\text { employers believe that } \\
\text { the OPs advice supports } \\
\text { RTW) }\end{array}$ & $\begin{array}{l}\text { 'e5 services, systems and policies', 'e590 } \\
\text { labour and employment services, systems } \\
\text { and policies' and especially 'e5900 labour } \\
\text { and employment services' }\end{array}$ \\
\hline $\begin{array}{l}\text { * Effective financial stimuli by the social } \\
\text { insurance office }\end{array}$ & RTW & $\begin{array}{l}\text { 'e5 services, systems and policies', 'e550 } \\
\text { legal services, systems and policies' and } \\
\text { especially 'e } 5502 \text { legal policies' }\end{array}$ \\
\hline
\end{tabular}




\begin{tabular}{|c|c|c|}
\hline Environmental factors & Factors may stimulate & Factors in ICF coding \\
\hline 4. Supervisors' communicative skills & $\begin{array}{l}\text { RTW (according to } \\
\text { findings related to } \\
\text { employees, this may } \\
\text { prevent conflict between } \\
\text { employees and } \\
\text { employers which may } \\
\text { otherwise inhibit RTW) }\end{array}$ & $\begin{array}{l}\text { Environmental, no specific ICF sub code } \\
\text { applies to this factor }\end{array}$ \\
\hline Personal factors & Factors may stimulate & Factors in ICF coding \\
\hline $\begin{array}{l}\text { 1. Employees' positive perception of the } \\
\text { situation (for example enjoyment of their } \\
\text { work) }\end{array}$ & RTW & $x$ \\
\hline
\end{tabular}

Note. RTW = return-to-work, OP = occupational physician

\section{Environmental factors}

Social support from relatives may benefit RTW. One employee described the importance of social support: "My wife and I were in the same situation [stress- related complaints] ... we didn't support each other much [to realise RTW]" (\# 5, employee, male). This employee reported to experience a need for support to cope with medical recovery: "I had to handle the health complaints on my own" (\# 5, employee, male). These two quotes suggest how social support provided by relatives may support medical recovery and RTW.

A belief that RTW supports medical recovery may benefit RTW. Employees who participated in our study reported to believe that RTW could inhibit medical recovery. "People [that is, family] tell me that I am sick and really shouldn't work" (\# 4, employee, male). Therefore these employees did not resume work before feeling healthy enough, which in turn delayed RTW.

Our findings illustrate a need for more effective cooperation between employees and HR professionals and supervisors on the one hand and curative professionals, OPs and the social insurance office on the other regarding activities to realise RTW. Currently, employees and HR professionals reported to experience difficulty in supporting RTW, and consequently ask professionals such as OPs to find a solution for the problematic RTW. The curative professionals and OPs on the other hand do not always support RTW, for example, by providing inadequate treatment. A lack of adequate cooperation was often found to delay RTW. Below, we describe several subthemes within this overarching theme.

On the one hand, employees and HR professionals reported to experience difficulty in stimulating the employees' early RTW themselves and asked professionals such as OPs to provide support.

First of all, to decide on which and how bottlenecks for RTW are solved, there is a need for agreement between employees on the one hand and HR professionals and 
supervisors on the other hand regarding the bottlenecks and desired intervention. Employees and HR professionals often described different, unarticulated, perspectives. For example, HR professionals primarily emphasised a need for medical intervention: "A timely medical treatment is very important for realising RTW" (\# 8, HR professional, male). Employees, on the other hand, emphasised a need for modified work: "I didn't want direct contact with clients anymore" (\#2, employee, female). Because these perspectives were not discussed, employees and HR professionals could not solve (especially the work-related) bottlenecks in RTW themselves.

Work modifications were described to be important to enable employees to resume work. One employee said that he could not resume work "until the new job is created" (\# 3, employee, male). However, especially some HR professionals with Small and Medium Enterprises (SMEs) lacked knowledge about possibilities for work modifications: "I do not know how to modify work for a depressed person" (\# 1, HR professional, female). One OP recognised that in SMEs there may also be limited possibilities to modify work: "If there are two cash points in a shop, the employer can't introduce another six [to create jobs]" (\# 3, OP, male).

Moreover, our findings illustrate the importance of the employees', $H R$ professionals' and supervisors' adequate appeal to the OP and social insurer for support. Usually, employees, HR professionals and supervisors made a strong appeal to OPs for support: "They say 'help us"” (\# 1, OP, male). An HR professional described how the OPs advice was used as a decision by employees and supervisors: "Their action plan stems directly from the OPs problem analysis" (\# 5, HR professional, male). Some employees "relied on the OP for every decision regarding RTW" (\# 11, employee, male). Some OPS reported to be disappointed about the employees' lack of initiative to return to work and considered them "rather passive" (\# 4, OP, male). Some HR professionals described to use a second opinion of the social insurer "to make sure that we're taking the right decision [regarding RTW]" (\# 13, HR professional, female). In case they were insecure about whether they were doing enough to support RTW, HR professionals encouraged their employees to "request a second opinion" (\# 8, employee, male). "By doing this, the HR professionals try to prevent the social insurance office from blaming them afterwards for not undertaking certain activities to support RTW" (\# 1, OP, male).

On the other hand, professional curative support and support by OPs appeared to be inadequate in many cases. Employees, HR professionals and OPs, for instance, mentioned the importance of adequate and timely treatment. Sometimes the employees' medical complaints persisted due to inadequate curative treatment. One employee reported: "There is simply no treatment for this disease" (\# 9, employee, female). Delays in treatment were said to be due to "a long time before a diagnosis is made" (\# 4, employee, male). Another employee mentioned "a waiting list" (\# 14, employee, female) to delay RTW. OPs admitted that "it can take a long time for a situation to be diagnosed" (\# 3, OP, male). HR professionals and supervisors usually did not plan RTW activities before knowing the medical diagnosis: "Once the diagnosis is 
known, one can provide tailor-made support" (\# 12, HR professional, male). Curative professionals in many cases advised employees that they "could not work" (\#2, employee, female). HR professionals, on the other hand, reported to be disappointed: "they [curative professionals] are unable to provide usable advice" (\# 2, HR professional, male) and sometimes told employees that the advice not to resume work was "not feasible" (\# 2, HR professional, male). OPs recognised that in this situation "a patient doesn't know what to do" (\# 3, OP, male) regarding RTW.

Also, our findings illustrate a need for the OPs to take an adequate role. OPs took on a range of different roles. For example, the topics on which some OPs advised varied across the broad field of "work and life" (\# 9, employee, female), while others primarily decided in consultation with employees that it would be best for the employee "to start working again" (\# 10, employee, female). The extent to which the OPs stimulated employees and HR professionals and/or supervisors to adopt their advice also varied. For example, one OP felt that if she placed herself in the employer's position she would "increase his problem" (\# 2, OP, female). This OP also considered some colleague OPs to "not advise employees and HR professionals and/or supervisors regarding RTW but decide about RTW themselves" (\# 2, OP, female). Some employees and HR professionals reported to be unsatisfied with the OPs advice. An HR professional said that when she asked for advice "the OP was not at all interested in sickness absence" (\# 6, HR professional, female). An employee said that her OP advised her "not to work so hard. That type of work just does not exist at my employer" (\# 14, employee, female). Some employees thought that "an OP is paid by an employer and therefore solely aims to get you to resume work as soon as possible" (\# 12, employee, male).

Adequate financial stimuli may encourage employees to resume work. Particularly those employees who reported to feel dependent on their income to continue living in their houses told that they were willing to return to work as a result of financial stimuli provided by the social insurance office: "Because of financial reasons, I finally said that even if I have to crawl over the office floors [because of the pain], no one is going to stop me from working there" (\# 3, employee, male).

These findings all suggest a need for employees, HR professionals and supervisors, curative health professionals, OPs and the social insurance office to cooperate effectively to stimulate RTW.

Finally, some HR professionals reported that supervisors lack communicative skills: "Communication and personal attention [such as asking how an employee on sick leave is doing] are often lacking in supervisors" (\# 13, HR professional, female). One OP believed that supervisors "should recognise their need for training" (\# 3, OP, male). In cases of conflict between employees and supervisors, the employees often attributed the conflict to their supervisors' lack of communicative skills: "My supervisor presented a distorted version of the truth... he can't communicate" (\# 12, employee, male). These 
findings suggest the relevance of improving communicative skills. Below, we describe a personal factor that may stimulate RTW.

\section{Personal factor}

This section describes one personal factor related to the employees' perceptions of the situation. Our findings illustrate the importance of employees having a positive perception of their situation. In many cases, the employee reported a rather negative perception of the work situation: "I do not enjoy work at all" (\# 1, employee, male). The negative perception can also relate to difficulties in combining volunteer aid activity and paid work. An employee who supported a disabled spouse after working hours said: "I have a 24-hour job... which doesn't really count for anything in this organisation" (\# 3, employee, male). Some employees reported a negative perception of their own education, work experience and chances of finding a job on the labour market: "But what can I apply for?" (\# 4, employee, male).

An OP noted that HR professionals and supervisors tend to be annoyed in case employees are "too careful in resuming work or do not want to perform certain work tasks" (\# 2, OP, female). HR professionals referred to these employees as not being "supportive of their own RTW" (\# 10, HR professional, female).

In conclusion, the participants reported to feel that environmental and personal factors had a direct influence on RTW. An example of such a factor is cooperation between employees, HR professionals and supervisors, curative professionals, OPs and the social insurance office. In addition, we found that factors such as adequate treatment may support medical recovery. Other than the factors that stimulate RTW, we also studied the possibilities of classifying the factors by using ICF coding. This is described below.

\section{Classification of the factors using ICF coding}

Table 2 provides an overview of the factors that can and those that cannot be classified using ICF coding. This table shows that factors can either fully (environmental: 'social support' and 'the belief that RTW supports medical recovery'), partially (environmental: 'effective cooperation to support RTW') or not at all ('supervisors' communicative skills') be classified with the help of ICF coding. Because the ICF does not include a list of personal factors, the 'employees' positive perception of their situation' cannot be described. The ICF classification of our results will be elaborated upon below.

\section{Factors that can be fully described by ICF coding}

The results illustrate the importance of social support provided by relatives such as a partner to help employees cope with medical recovery. This factor can be described by the ICF code 'e3 support and relationships', because it includes emotional support. The 
sub code 'e310 immediate family', which describes support from a partner, also applies to this factor [23].

Our findings also suggest that early RTW is possible in case employees believe that RTW can contribute to medical recovery. This can be described by the ICF code 'e4 attitudes'. According to its definition, attitudes influence individual behaviour in, for example, interpersonal relationships, as was the case with the study participants. Our findings suggest that the employees' relatives usually have a strong influence on employees' opinion about an appropriate timing for RTW. The ICF sub code 'e410 individual attitudes of immediate family members' particularly applies to this factor because this code specifically addresses the attitudes of the employees' relatives [23].

\section{Factors that can be partially described by ICF coding}

The results illustrate the importance of cooperation between employees, HR professionals and supervisors on the one hand and health and occupational professionals on the other. We defined different subthemes within this overarching theme, which applied to the domains of labour, health and legislation.

First, the need for employees on the one hand and HR professionals and supervisors on the other hand to agree on the bottlenecks and the related need for interventions applied to the domain of labour. This was also the case in the following themes: a need for 'success in modifying work'; 'employees', HR professionals' and supervisors' adequate appeal on the OP and social insurance office for support' and the 'various ways of role taking by OPs'. Other themes applied to the domain of health, such as a need for 'timely and adequate curative treatments', or the domain of legislation, such as the need for 'effective financial stimuli by the social insurance office'.

The subthemes in the field of labour can be described by the ICF code 'e5 services, systems and policies', which covers structures, programmes and operations designed to meet the needs of individuals. More specifically, these subthemes are described by codes 'e590 labour and employment services, systems and policies' and 'e5900 labour and employment services', which refer to human services such as resources and personnel management and occupational health and safety. However, ICF coding is too general to describe specific factors within the labour and employment services, such as the need for employees on the one hand and HR professionals and supervisors on the other hand to agree on what bottlenecks for RTW exist [23].

Similarly, the subthemes that apply to the field of health can be described by the ICF codes 'e580 health services, systems and policies' and especially 'e5800 health services', which, among others, refer to treatments provided in hospitals. ICF coding, however, is too general to describe the adequacy of treatment. In addition, ICF coding does not include time and, therefore, does not enable us to describe the timeliness of medical treatment.

The subtheme for legislation (effective financial stimuli by the social insurance office) can be described by the ICF codes 'e550 legal services, systems and policies' and 
'e5502 legal policies'. However, these do not refer specifically to the social insurance office [23]. The overarching theme of the subthemes mentioned above was an effective cooperation between employees and HR professionals and supervisors on the one hand and curative professionals, OPs and the social insurance office on the other. This theme cannot be described with the help of ICF coding. The ICF does include specific codes for services, systems and policies in health, labour and legislation, but not for cooperation between actors in health (curative professionals), labour (employees, HR professionals and supervisors) and legislation (the social insurance office), which was relevant for the factor that we found [23].

\section{Factors that cannot be described by ICF coding}

The 'supervisors' communicative skills' appeared to be an important factor, but there is no specific environmental ICF code for it. From the employees' perspective, supervisors' communicative skills may be considered an environmental factor. However, from a supervisors' perspective, this factor may be considered a limitation in communication activities, which we did not investigate in this article. The interview study yielded one personal factor: the employees' perception of the situation. This factor could not be classified, because the ICF does not contain codes for personal factors [23].

\section{Discussion}

The study aims were (1) to identify which environmental and personal factors support employees' RTW and investigate how they support RTW, and (2) to examine whether professionals can use the ICF to describe these factors. We performed in-depth interviews with 14 employees, 15 employers (in this study, the employers were represented by the HR professionals) and 5 OPs. The results showed a number of environmental factors that are relevant for RTW. For example, social support from relatives to cope with medical complaints and the belief that work is good for health were found to support employees to return to work. In addition, adequate cooperation between stakeholders in RTW (employees, employers, curative professionals, OPs and the social insurance office) was found to support RTW. Cooperation between these stakeholders may support adequate medical treatment and work modifications that enable employees to resume work. The supervisors' communicative skills also appeared important for effective cooperation with their employees. Our study also showed that one personal factor supported RTW, which involved employees having a positive perception of the situation such as experiencing enjoyment at work. Most factors we identified in this study support RTW directly. Adequate treatment and social support from relatives were also found to support medical recovery.

To target their RTW interventions, professionals can use the ICF to describe a number of environmental factors that influence RTW. Environmental factors can fully 
(social support, believing that RTW supports medical recovery), partially (effective cooperation between actors), or not (supervisors' communicative skills) be described using ICF codes. The personal factor could not be classified using the ICF either because the ICF does not contain coding for personal factors.

To our knowledge, this is the first study to investigate the usefulness of the ICF for describing the environmental and personal factors that may support early RTW in a general population of employees on sick leave (i.e. employees with various health complaints). This study is also unique in that it includes the perspectives of several stakeholders, namely employees, employers and OPs, in a qualitative research design.

Earlier studies have described general factors that may influence RTW, such as social support [2-20]. The results of our interview study go one step further, and also illustrate the type of social support that is relevant and how social support may benefit RTW. The results have extended our appreciation and understanding of the complex interactions between various stakeholders in the RTW process. Such in-depth information may support occupational health professionals to target their interventions more specifically to these factors.

\section{Study limitations}

This study has several limitations. First, the results section of this article includes relatively few quotes from female employees. Our sample included more male than female employees. However, the quotes of the men generally were more explicit than those of women: the women appeared to be more nuanced when talking about the environmental and personal factors. Research has also shown differences in communication between men and women [38]. However, despite these differences, both the men and women in our study appeared to experience the same environmental and personal factors.

In the interview study, we found more factors that apply to cooperation between employees and employers, supervisors' communicative skills and cooperation with the $\mathrm{OP}$ than in the literature referred to in the introduction of this article. Both the interviewer and the Dutch participants might have been more aware of these factors than in studies elsewhere, because these relate to the Dutch Improved Gatekeeper Law. This law prescribes a minimum level of cooperation between employees on sick leave and their employers.

All interviews were semi-structured. They were approximately two hours in length. One interview with an employer was only 30 minutes in length (because of conflicting appointments in the interviewee's agenda). We do not think that this short duration influenced our results. This employer answered all interview questions concisely. We also checked the interviews with males and females for differences in response time. We could not find any remarkable differences. 
One author (NH) conducted and analysed the interviews. We do not think that there was any negative impact of this on the study results or their interpretation, because we still used researcher triangulation in the process of analysing the data. In regular author meetings, we discussed the ways interviews were conducted, and the results of different steps in interview analysis. This researcher triangulation can reduce the possibility of biased interpretation of the data. The data analysis can also benefit from divergent perspectives of researchers [32].

Finally, the researchers noticed that the employers tended to provide socially desirable answers. The factors experienced by the employers might thus be even more important for early RTW than the data suggest. This would actually reinforce our study results.

How to improve the effectiveness of interventions?

The first study aim was to identify which environmental and personal factors support employees' RTW and investigate how they support RTW. Professionals who develop RTW interventions can make use of our study findings. For example, RTW interventions generally aim to help employees return to work during their medical recovery. These interventions are based on the underlying idea in the ICF that people with impaired body functions and limitations in activities can still work [39] and on EU policies that stimulate these people to participate according to their ability [34,35]. However, our findings suggest that employees and employers act in line with the medical model, which states that employees should not resume work until they have recovered sufficiently [40]. They may be unaware of recent study findings that have shown that early RTW often supports medical recovery [1]. Our findings suggest that when employees and employers are aware of this, they benefit more from RTW interventions. Based on these findings, we plan to develop and test professional support (including coaching of employees and employers) to stimulate RTW during medical recovery and to decrease the length of sickness absence.

Findings from the Dutch situation show that ineffective cooperation between stakeholders in RTW (employees, employers and health and occupational professionals) may itself form a bottleneck, which may complicate solutions for 'actual' bottlenecks such as modifying work tasks that do not match employees' limitations in activities. This illustrates the importance of initiatives to monitor a clear division of tasks based on actors' role descriptions in national policies [36].

Our analysis using the ICF, a biopsychosocial model, suggests that the focus, which in many current RTW interventions does not extend beyond the workplace [41,42], should cover factors in three domains: the workplace, social support from employees' relatives and supporting employees (self-management) to realise early and effective RTW $[43,44]$. Hence, our results suggest that professionals, who stimulate certain 
environmental and personal factors, enable employees to participate according to their ability.

The second aim of our study was to examine whether professionals can use the ICF to describe the environmental and personal factors. The study results illustrate additional issues related to ICF and/or ICF factors. It is not clear yet how these can be taken into account in RTW interventions. For example, three stakeholders (employees, OPs and the employers/HR professionals) experienced a lack of communicative skills in supervisors. When there was conflict between employees and supervisors, the employees often attributed this to their supervisors' lack of communicative skills. However, this theme may also reflect a lack of effort or skills on the part of both employees and supervisors. Further studies may examine this issue.

Also, the ICF does not classify personal factors due to large intercultural variations in whether aspects of human functioning (for example in RTW) might be attributed to the individual [39]. Our results illustrate how actors can use personal factors to place part of the responsibility for a lack of progress in RTW on others. Employers attributed difficulties in realising RTW to employees with a negative perception of the situation (e.g. who did not enjoy their work). Employers can, however, encourage employees' perceptions (a personal factor) to be more positive, for example, by providing modified work. Further studies could focus on how to classify personal factors while preventing individuals from using these to place responsibility for participation limitations on others.

The ICF also does not include 'time'; professionals can only use the ICF to describe environmental and personal factors influencing RTW at one particular moment. Factors, however, may be susceptible to changes over time. For example, social support by relatives may decline when a person is ill for a prolonged period. Longitudinal research could provide insight into the stability of factors over time. Clarification of these issues may help to incorporate 'communicative skills', 'personal factors' and 'time' in a derivative version of the ICF for RTW and in ICF-based interventions.

\section{Acknowledgements}

The authors thank Dr Yvonne Heerkens for her helpful comments on this manuscript. Funding and support for this study was granted by the Dutch foundation 'Stichting Instituut Gak-SIG'. Acknowledgement and thanks is also given to the study participants. 


\section{References}

1. Waddell G, Burton AK. Is work good for your health and well-being? London: TSO, 2006.

2. Friesen MN, Yassi A, Cooper J. Return-to-work: The importance of human interactions and organisational structures. Work. 2001;17:11-22.

3. Baltov P, Cote J, Truchon M, Ehrmann Feldman D. Psychosocial and socio-demographic factors associated with outcomes for patients undergoing rehabilitation for chronic whiplash associated disorders: A pilot study. Disabil Rehabil. 2007;30:1947-55.

4. Burger H, Marincek CRT. Return to work after lower limb amputation. Disabil Rehabil. 2007;29:1323-9.

5. Alaszewski A, Alaszewski H, Potter J, Penhale B. Working after a stroke: Survivors' experiences and perceptions of barriers to and facilitators of the return to paid employment. Disabil Rehabil. 2006;29:1858-69.

6. Lysaght RM, Larmour-Trode S. An exploration of social support as a factor in the return-to-work process. Work. 2006;30:255-66.

7. Svensson T, Müssener U, Alexanderson K. Sickness absence, social relations, and self-esteem: A qualitative study of the importance of relationships with family, workmates, and friends among persons initially long-term sickness absent due to back diagnoses. Work. 2010;37:187-97.

8. Landstad B, Hedlund M, Wendelborg C, Brataas H. Long- term sick workers' experience of professional support for re- integration back to work. Work. 2009;32:39-48.

9. van Duijn $M$, Miedema $H$, Elders L, Burdorf A. Barriers for early return-to-work of workers with musculoskeletal disorders according to occupational health physicians and human resource managers. J Occup Rehabil. 2004;14:31-41.

10. Lidal IB, Huynh TK, Sorensen FB. Return to work following spinal cord injury: A review. DisabilRehabil. 2007;29:1341-75.

11. Rosenfeldt M, Hay C. Managing chronic pain and return to work in the "real world": A case study. Work. 2008;30:317- 21.

12. Esselman PC, WiechmanAskway S, Carrougher GJ, Lezotte DC, Holavanahalli RK, Magyar-Russell G, Fauerbach JA, Engrav LH. Barriers to return to work after burn injuries. Arch Phys Med Rehabil. 2006;88:55-6.

13. Schweigert MK, McNeil D, Doupe L. Treating physicians' perceptions of barriers to return to work of their patients in Southern Ontario. J Occup Med. 2004;54:425-9.

14. Hollness D.L. Return-to-work barriers for workers with contact dermatitis. Contact Dermatitis. 2004;49:273-5.

15. Sampere M, Gimeno D, Serra C, Plana M, Martínez JM, Delclos GL, Benavides FG. Effect of working conditions on non-work-related sickness absence. J Occup Med. 2011. doi:10.1093/occmed/kqr141.

16. Sampere M, Gimeno D, Serra C, Plana M, Martínez JM, Delclos GL, Benavides FG. Organizational return to work support and sick leave duration: A cohort of Spanish workers with a long-term non-work-related sick leave episode. J Occup Environ Med. 2011;53:674-9.

17. Anema JR, Jettinghoff K, Houtman ILD, Schoemaker CG, Buijs PC, van den Berg R. Medical care of employees long-term sick listed due to mental health problems: A cohort study to describe and compare the care of the occupational physician and the general practitioner. J Occup Rehabil. 2006;16:38-49.

18. Briand C, Durand MJ, St-Arnaud L, Corbiere M. How well do return to-work interventions for musculoskeletal conditions address the multicausality of work disability? J Occup Rehabil. 2008;18:20717.

19. van Rhenen W, Schaufeli WB, vanDijk FJH, Blonk RWB. Coping and sickness absence. Int Arch Occup Environ Health. 2008;81:461-72.

20. Sampere M, Gimeno D, Serra C, Plana M, López JC, Martínez JM, Delclos GL, Benavides FG. Return to work expectations of workers on long-term non-work-related sick leave. J Occup Rehabil. 2011. doi:10.1007/s10926-011-9313-5.

21. Jansson I, Björklund A. The experience of returning to work. Work. 2007; 28: 121-34. 
22. Lydell M, Grahn B, Månsson J, Baigi A, Marklund B. Predictive factors of sustained return to work for persons with musculoskeletal disorders who participated in rehabilitation. Work. 2009;33:317-28.

23. World Health Organization. ICF browser. [date unknown]. http://apps.who.int/classifications/icfbrowser/. Accessed 17 Nov 2011.

24. Cerniauskaite M, Quintas R, Boldt C, Raggi A, Cieza A, Bickenbach JE, Leonardi M. Systematic literature review on ICF from 2001 to 2009: Its use, implementation and operationalisation. Disabil Rehabil. 2011;33:281-309.

25. Leyshon RT, Shaw LE. Using the ICF as a conceptual framework to guide ergonomic intervention in occupational rehabilitation. Work. 2008;31:47-61.

26. Homa DB. Using the International Classification of Functioning, Disability and Health (ICF) in job placement. Work. 2007;29:277-286.

27. Tamminga SJ, de Boer AGEM, Verbeek JHAM, Frings-Dresen MHW. Breast cancer survivors' views of factors that influence the return-to-work process - a qualitative study. Scand J Environ Health. 2011. doi: 10.5271/sjweh. 3199.

28. Cornelius LR, van der Klink JJL, Groothoff JW, Brouwer S. Prognostic factors of long term disability due to mental disorders: a systematic review. J occup rehabil. 2011;21:259-74.

29. Muijzer A, Brouwer S, Geertzen JH, Groothoff JW. Exploring factors relevant in the assessment of the return-to-work process of employees on long-term sickness absence due to a depressive disorder: A focus group study. BMC Public Health. 2012;12:103.

30. Glässel A, Finger ME, Cieza A, Treitler C, Coenen M, Escorpizo R. Vocational rehabilitation from the client's perspective using the International Classification of Functioning, Disability and Health (ICF) as a reference. J Occup Rehabil. 2011;21:167-178.

31. Glässel A, Rauch A, Selb M, Emmenegger K, Lückenkemper M, Escorpizo R. A case study on the application of International Classification of Functioning, Disability and Health (ICF)-based tools for vocational rehabilitation in spinal cord injury. Work. 2012;41:465-474.

32. Polit D, Beck CT. Nursing research: Generating and assessing evidence for nursing practice. 8th ed. Philadelphia: J. B. Lippincott, 2008.

33. Beljaars $P$, Prins R. Disability programme reforms and labour market participation in the Netherlands (1990-2000): Principles, measures and outcomes in a decade of combating high disability rates. 2000. http://www.issa.int/pdf/helsinki2000/topic2/2beljaars.PDF. Accessed 24 March 2011.

34. Annesley C. Lisbon and social Europe: Towards a European 'adult worker model' welfare system. J EurSoc Pol. 2007;17:195-205.

35. Klosse S. Active inclusion: From aspiration to action; how European countries bring the social dimension to life. Maastricht: Maastricht University, 2009.

36. Ministerie van Sociale Zaken en Werkgelegenheid. Ziekteverzuim van het werk [Sickness absence]. http://www.rijksoverheid.nl/onderwerpen/ziekteverzuim-van-het-werk. Accessed 9 Dec 2011.

37. Dierckx de Casterlé B, Gastmans C, Byron E, Denier Y. QUAGOL: A guide for qualitative data analysis. Int J Nursing Studies. 2011. doi:10.1016/j.ijnurstu.2011.09.012.

38. Lagro-Janssen ALM. De geneeskunde is niet genderneutraal: Invloed van de sekse van de dokter op de medische zorg [Medicine is not gender-neutral: Influence of the gender of the doctor on medical care]. Ned TijdschrGeneeskd. 2008;152:1141-5.

39. World Health Organization. International Classification of Functioning, Disability and Health (ICF). Geneva: WorldHealth Organization [date unknown]. http://www.disabilitaincifre.it/documenti/ICF_18.pdf. Accessed 24 Jan 2013.

40. Barbour A. Caring for patients. A critique of the medical model. 1st ed. Stanford: Stanford University Press; 1995.

41. Arnetz BB, Sjörgen B, Rydéhn B, Meisel B. Early workplace intervention for employees with musculoskeletal-related absenteeism: A prospective controlled intervention study. J Occup Environ Res. 2003;45:499-506. 
42. Bültmann U, Sherson D, Olsen J, Lysbeck Hansen C, Lund T, Kilsgaard J. Coordinated and tailored work rehabilitation: A randomized controlled trial with economic evaluation undertaken with workers on sick leave due to musculoskeletal disorders. J Occup Rehabil. 2009;19:81-93.

43. Varekamp I, de Vries G, Heutink A, van Dijk FJH. Empowering employees with chronic diseases; development of an intervention aimed at job retention and design of a randomised controlled trial. BMC Health Serv Res. 2008;8:224.

44. van der Klink JJL, Blonk RWB, Schene AH, van Dijk FJH. Reducing long term sickness absence by an activating intervention in adjustment disorders: A cluster randomised controlled design. J Occup Environ Med. 2003;60:429-37. 


\section{CHAPTER 4}

Work resumption at the price of distrust: a qualitative study on return to work legislation in the Netherlands

This chapter was published as:

Hoefsmit N, de Rijk A, Houkes I

BMC Public Health. 2013;13:153. 


\section{Abstract}

Background: Return to work (RTW) after sick leave is considered necessary to support the employees' health. Cooperation between employees and employers may encourage employees' RTW, but is hampered by bottlenecks that we do not completely understand. Dutch legislation means to support this cooperation and allows trying RTW during two years. The Resource Dependence Institutional Cooperation (RDIC) model has been developed for studying cooperation in public health. Study aims were to get insight into the degree of cooperation between Dutch sick-listed employees and employers, how this (lack of) cooperation can be understood, and how valid the RDIC model is for understanding this (lack of) cooperation.

Methods: This qualitative study was based on in-depth interviews with 8 employees and 8 employers. Employees reported sick for 1.5-20 months for various reasons. Interviews were analysed using an interpretative approach and pattern matching.

Results: Cooperation was lacking early during sick leave. Later on there were regular meetings, but employers decided about RTW without consulting the employees. Particularly employers were motivated to cooperate during the first year, while employees were especially motivated during the second. This could be understood by experienced dependence; employees (first year) and employers (second year) did not consider cooperation to be important for achieving medical recovery (employees) or RTW (employers). These divergent goals may be understood by personal norms about the timing of medical recovery and RTW. Legislation was particularly effective regarding employer behaviour in year 1 and employee behaviour in year 2. Employees distrusted their employers during the first year, while employers reported to distrust the employees during the second year. Besides, employees and employers experienced a moderate ability to cooperate. This could be understood particularly by having moderate knowledge about legislation. The RDIC model appeared to be valid to understand the cases studied, but the additional factor distrust also played a role.

Conclusions: Legislation appeared to support cooperation, but awareness of a mutual dependence, trust, knowledge about the legislation and personal norms regarding recovery and RTW are also important. Professionals such as occupational physicians should support this to attain a degree of cooperation that is necessary for effective RTW. 


\section{Background}

Effective return to work (RTW) after sick leave is an important public health topic. Across the European Union (EU), early and effective RTW is considered necessary to support sick-listed employees' health and well-being. RTW also prevents them from losing their jobs, which has adverse effects. For employers and governments, the financial benefits of paying less for sick leave and state subsidies play a role as well [1]. This fits in with the general aim of improving the sustainable employment and labour participation of all citizens [2]. Especially in view of an ageing population and the current economic crisis, sustainable employment is important. Therefore, several EU countries have put RTW after sick leave high on the political agenda.

Effective cooperation between sick-listed employees and their employers is considered a key element in early and effective RTW [3-8]. The employee's perspective is important to understand RTW practice [9]. Many studies, however, demonstrate bottlenecks that inhibit cooperation in RTW, such as lack of communication and conflicting stakeholder opinions (see, for example, [10-15]).

Interestingly, the Netherlands seem to have the most advanced legislation of all EU countries regarding cooperation in relation to RTW. The Dutch Improved Gatekeeper Act imposes on sick-listed employees and their employers the responsibility to cooperate for achieving early and effective RTW. This legislation describes obligatory procedures for employees and employers to follow, such as composing an action plan for RTW. Occupational physicians (OPs) contracted by employers analyse the employees' functional limitations and advise about RTW possibilities. Employees are compensated by their employers for at least $70 \%$ of their income during two years of sick leave. However, there are differences in legislation for the early and later periods of absence. Most employers pay up to $100 \%$ of the regular wage during six to twelve months, which means that the financial incentive to return to work is only truly felt after this period. If still sick-listed after two years, employees can apply for a long-term disability benefit. They will receive a pension if their earning capacity (the maximum income the person can still earn) has declined by $35 \%$ or more. The exact amount of these pensions therefore depends on the earning capacity left. The social insurance physician assesses the employees' work ability and, also, the action undertaken by employee and employer to realise RTW during the two years of sick leave. Failure to cooperate as prescribed by law is sanctioned with, for instance, an additional year of wage payment obligation for the employer [16-18].

Despite this legislation, Dutch employees and employers still complain about lack of adequate cooperation $[13,15]$. Current evidence on what the bottlenecks constitute is limited. Better understanding of these bottlenecks is important, so that lessons can be learned and recommendations can be formulated for other countries. Public health professionals in RTW, such as OPs, professionals who develop interventions and policy makers can benefit from understanding the bottlenecks. A Canadian study by Maiwald 
et al. showed that those who design interventions often have a different perception of the support needed to return to work than the affected employees [19]. The Netherlands offer a unique case to study the potential impact of legislation on cooperation in RTW. It is important that RTW professionals gain better understanding of employees' and employers' cooperation and learn about the potential influence of legislation. We aim to perform an analysis of cooperation that is relevant for both policy makers in RTW and actors in practice such as employees, employers and OPs.

According to policy sciences, rules may influence cooperation and social science tells us that for example motivation can influence cooperation [20,21]. Interestingly, De Rijk, Van Raak and Van der Made developed a model which combines both perspectives. This is the Resource Dependence Institutional Cooperation (RDIC) model (see Figure 1) [3]. The theoretical model is used for understanding cooperation in public health settings such as sick leave and work resumption. It has a high internal validity as it has been constructed on the basis of established theories and was tested empirically [3].

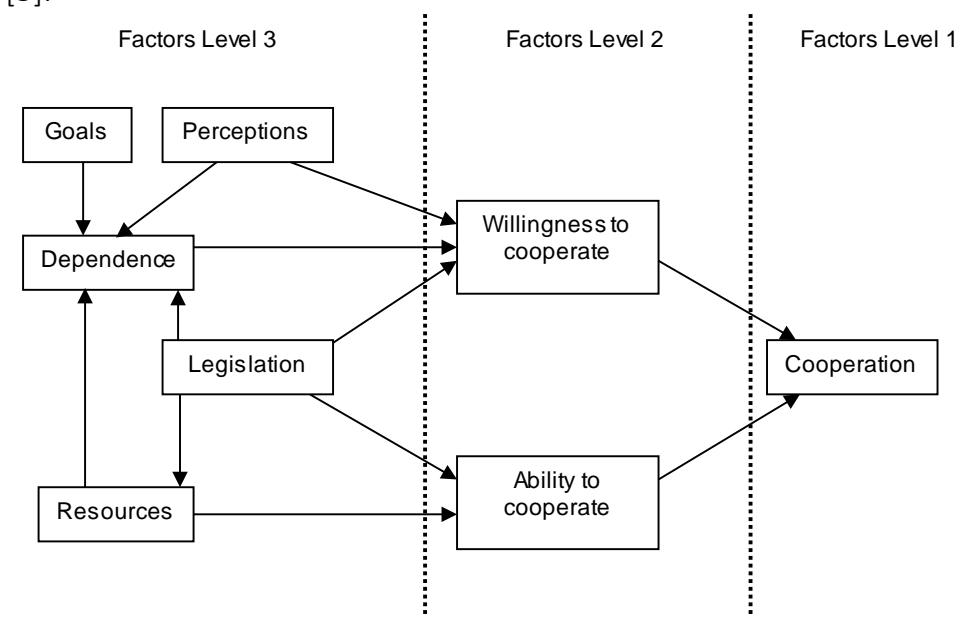

Figure 1. The Resource Dependence Institutional Cooperation (RDIC) model [3]

De Rijk et al. composed the model of three levels. The first is the cooperation itself, defined as making agreements and acting accordingly. To understand cooperation, there is a second level in the model, which covers willingness and ability. For cooperation to exist, actors must not only be willing to, but also be able to cooperate. The model incorporates other theories in a third level, which reflects the factors that underlie the willingness and ability to cooperate. For example, actors may be unable to cooperate when they lack time to meet. More specifically, the RDIC framework covers two underlying mechanisms of willing ness and ability to cooperate. The first mechanism is based on institutions. Institutions are rules that shape human behaviour and include legislation and sanctions. In this study, we only included legislation as an institution in the model, because we are mainly interested in the effect of the Dutch 
Improved Gatekeeper Law on the cooperation between sick-listed employees and their employers. An earlier study also focused primarily on the role of legislation [3]. According to the RDIC model, legislation may affect the ability to cooperate - for example by prescribing how actors may cooperate - and, also, the willingness to cooperate - for example by prescribing a minimum number of meetings [3]. The second mechanism underlying willingness and ability to cooperate was derived from resourcedependence theory [3]. This theory assumes that actors will cooperate only if they feel dependent on each other for acquiring the resources needed to achieve their own goals (such as work modifications needed for return to work) and have positive perceptions of each other. The RDIC model includes the resource-dependence theory in the factors goals, dependence, resources and perceptions [3].

In this study, we are in the first place interested in understanding the cooperation between sick-listed employees and their employers. In our analysis of this cooperation, we were inspired by the RDIC model. This raises the question whether the RDIC model is valid for understanding the cooperation. Does it help to understand why in some cases cooperation is low and in others high, or are additional factors necessary to understand cooperation in RTW? In the publication of 2007, data from a year before the Improved Gatekeeper Law were used and the dynamics might have been different [3]. We formulated the following research questions: 1) To what degree is there cooperation between Dutch sick-listed employees and employers? 2) How can this (lack of) cooperation be understood? and 3) How valid is the RDIC model for understanding this (lack of) cooperation?

\section{Methods}

\section{Design and participants}

For the purpose of this study, we performed semi- structured interviews and recruited a sample of three complete cases (i.e. employee and representative of employer), five single employees and five single representatives of employers. The study was not submitted to an ethical committee. According to the Dutch law (Wet MedischWetenschappelijk Onderzoek met Mensen/Medical Research Involving Human Subjects Act) our type of study does not require ethical committee approval. We used purposive sampling to obtain the views of people with varying health complaints, ages, industries and places of residence (for practical reasons, we confined ourselves to the south of the Netherlands) [22].

The inclusion criteria for employees were that, at the time of the interview, they were long-term sick-listed (> 6 weeks), or had experienced long-term sick leave and had resumed work less than one year before the interview. We assumed that, after such a 
long period, employees would have a clear opinion about- and sufficient experience in cooperating with employers.

We studied the cooperation between absent employees on the one hand and supervisors and Human Resource (HR) professionals on the other hand. We did not interview any supervisors, because they usually have limited experience with (for example one or two) absent employees. Therefore, we chose to interview HR professionals on different levels (HR officers and HR managers) who have extensive experience with absent employees. We also interviewed a director occupational healthcare, who was involved in policy-making about and directing the organisation's occupational health services, for example by OPs or psychologists.

We aimed to recruit as many complete cases (i.e. employee and HR professional) as possible. First, we recruited HR professionals using the telephone book on the internet. We searched for both small and medium enterprises (SMEs) and larger organisations in a variety of sectors such as construction. The phone book provided us with the contact information of the organisations. At the end of the interviews with the HR professionals (which took place at their workplaces), we asked them to give us a referral to one particular employee, which resulted in three complete cases. Some employers refused to give referrals without explicit argumentation, or did not know of an employee who would be willing to participate. In these cases, we used other strategies to recruit employees. We randomly contacted four psychologists and four physiotherapists who treat sick-listed employees through their professional associations' websites. We asked each of these professionals to invite one client who met the inclusion criteria to participate in the study. Clients interested in participating subsequently gave their therapists permission to forward their telephone number to one of the researchers. In this way, three psychologists helped us to recruit three employees and one physiotherapist provided us with an additional employee. Finally, we recruited one additional employee through the first author's personal network. The final sample of employees had been absent from work due to sickness between 6 weeks and 20 months. As Table 1 shows, the sample covered both male and female employees of different ages and who had diverse health complaints. We stopped recruiting new participants when saturation was achieved. 
Table 1. Characteristics of participants

\begin{tabular}{|c|c|c|}
\hline Characteristic & Employee (8) & HR professional (8) \\
\hline Health complaints & $\begin{array}{l}\text { psychological (3) / physical (2) / } \\
\text { both (3) }\end{array}$ & \\
\hline Age & $<45$ years $(4) / \geq 45$ years $(4)$ & \\
\hline Gender & male (4) / female (4) & male (4) / female (4) \\
\hline Absence duration & $<1$ year $(4) / \geq 1$ year $(4)$ & \\
\hline Organisational size & $>150$ (6) / 20-150 (2) & >150 (7) / 20-150 (1) \\
\hline Sector & $\begin{array}{l}\text { profit }(5) \text {, cases* }(2) / \text { non-profit } \\
(3) \text {, cases* (1) }\end{array}$ & $\begin{array}{l}\text { profit }(5) \text {, cases* }(2) / \text { non-profit } \\
(3) \text {,cases* (1) }\end{array}$ \\
\hline Industry & $\begin{array}{l}\text { production industry ( } 2 \text { ), } \\
\text { healthcare ( } 2 \text { ), education (1), } \\
\text { commercial (3) }\end{array}$ & $\begin{array}{l}\text { technical (4), healthcare (2), } \\
\text { education (1), commercial (1) }\end{array}$ \\
\hline Profession & $\begin{array}{l}\text { cook (1), salesman (2), process } \\
\text { operator ( } 2 \text { ), teacher (1), } \\
\text { administrative assistant (1), } \\
\text { management assistant (1) }\end{array}$ & $\begin{array}{l}\text { HR officer (4), HR manager (3), } \\
\text { director occupational healthcare } \\
\text { (1) }\end{array}$ \\
\hline
\end{tabular}

* case = a pair consisting of an employee and an HR professional.

\section{Data collection}

The first author (NH) visited all participants at their homes (employees) or workplaces (HR professionals) for the semi-structured interviews. One interview lasted about 30 minutes and all others about two hours. The interview guide for both types of actors covered topics related to the cooperation between employees and the $H R$ professionals, such as whether meetings had been arranged, the issues that were discussed and the challenges met in achieving RTW. The guide also covered contacts with other actors, such as health care professionals and the employees' social environment (family, friends), so as to judge the influence of actors not included in the study on the employees' and HR professionals/supervisors' decisions regarding RTW.

Employees were asked to talk about their situation and the HR professionals about their experiences with sick-listed employees in general. The guide was used flexibly to enable participants to raise other issues they considered relevant. To challenge the accuracy and completeness of the information given, the interviewer prompted the participants using questions such as: Why.. .? Can you give an example? All interviews were tape-recorded with the participants' consent [22].

Data analysis

All interviews were transcribed verbatim. We started by reading and re-reading all transcripts to familiarise with the data. To answer our first research question (To what degree is there cooperation between Dutch sick-listed employees and employers?), we 
used pattern matching to compare the 'expected cooperation' (obligatory actions prescribed by legislation) to patterns of 'actual cooperation' [23]. To define the 'expected cooperation', we studied the text of the Dutch Improved Gatekeeper Law and practical guidelines about the law for employers and OPs [16-18]. This provided us with an overview of the official agreements on the cooperation between employees and employers. This included both the type of obligatory actions and the time when cooperation was required to take place. Then, we used the employee interviews to study 'actual cooperation' for each employee separately, followed by the overall degree of cooperation.

To answer our second research question (How can the (lack of) cooperation be understood?), we performed a data-driven analysis of interviews with the employees and HR professionals. We coded all interviews by searching for fragments that were consistent and meaningful parts (open coding). Then, we abstracted, defined and delineated concepts and decided about their relevance (axial coding). During the coding process, we were inspired by the RDIC model [3]. Next, we performed constant comparisons between and within cases to further refine the concepts. Then, definite themes were defined [24].

Finally, and to answer our third research question (How valid is the RDIC model for understanding this (lack of) cooperation?), we also applied pattern matching $[3,23]$. Pattern matching is an analytic strategy in theory-testing with cases. In this study we used pattern matching to compare the degrees of cooperation, motivation and ability that were observed in the data- to the expected ones. First, we quantified (by estimating these concepts as low, moderate or high) the actual/observed degrees of cooperation, motivation and ability in employees and employers using the interview data. Next, we compared the degree of cooperation based on motivation and ability (expected degree) with the actual degree of cooperation as observed in the data. The result of this comparison gives an indication of how well the theory covers the concept of cooperation. This comparison was also made for the concepts of motivation and ability. The expected degrees of motivation were defined using the concepts of dependence, legislation and perceptions. To define the expected degrees of ability, we used the concepts of resources and legislation. Thus, pattern matching may help to systematically analyse the fit of a model to the data [23].

Data analysis was performed manually. To ensure peer validity, the first author $(\mathrm{NH})$ frequently discussed the analyses and the results thereof with the other authors $(A d R, I H)$. 


\section{Results}

Below, we present the results regarding cooperation (research question 1). In a second paragraph we describe how this cooperation (or the lack thereof) can be understood (research question 2). In the third paragraph we present the findings regarding the validity of the RDIC model (research question 3 ).

\section{Cooperation (research question 1)}

Legislation requires employees and employers to 1) meet, 2) discuss the progress of RTW, 3) share decision-making on possible RTW and 4) purchase professional RTW interventions if necessary (Table 2).

Table 2. Cooperation between employees and HR professionals

\begin{tabular}{|c|c|c|c|c|c|}
\hline \multirow[b]{2}{*}{$\begin{array}{l}\text { Type of } \\
\text { agreement }\end{array}$} & & \multicolumn{2}{|c|}{ Year 1} & \multicolumn{2}{|c|}{ Year 2} \\
\hline & & Expected & Observed & Expected & Observed \\
\hline & 1. Meetings & $+(1,2,3,4,5,6,7,8)$ & $+-(1,2,3,4,5,6,7,8)$ & $+(1,2,3,6)$ & $+(1,2,3,6)$ \\
\hline & $\begin{array}{l}\text { 2. Mutual exchange of } \\
\text { information about RTW } \\
\text { possibilities }\end{array}$ & $+(1,2,3,4,5,6,7,8)$ & - $(1,2,3,4,5,6,7,8)$ & $+(1,2,3,6)$ & $-(1,2,3,6)$ \\
\hline & $\begin{array}{l}\text { 3. Shared decision-making } \\
\text { about RTW }\end{array}$ & $+(1,2,3,4,5,6,7,8)$ & $-(1,2,3,4,5,6,7,8)$ & $+(1,2,3,6)$ & $-(1,2,3,6)$ \\
\hline & $\begin{array}{l}\text { 4. Intervention to support } \\
\text { work resumption }\end{array}$ & $+(1,2,3,4,5,6,7,8)$ & - $(1,2,3,4,5,6,7,8)$ & $+(1,2,3,6)$ & $+(1,2,6),-(3)$ \\
\hline $\begin{array}{l}\text { Cooperation } \\
\text { summarised }\end{array}$ & & & - & & +- \\
\hline
\end{tabular}

Note. The expected cooperation consisted of the obligatory actions for employees and employers that were prescribed by the legislation. Whether the employee and HR professional or supervisor acted in line with the legislative obligations (observed cooperation) was assessed for each employee individually (see the numbers in the Table). The findings regarding cooperation were summarised afterwards.

+ yes, + - partially, - no.

Table 2 illustrates that employees and HR professionals or supervisors only partially followed through on these formal agreements. This was assessed for each employee individually. The findings regarding cooperation were summarised afterwards. It appeared that the degree of cooperation differed between the first and second year of sick leave.

\section{Lack of cooperation early during the first year of sick leave}

Table 2 shows that there was a low degree of cooperation during the first year of sick leave. Most employees and supervisors did not meet during the first eight weeks of sick leave. One employee noted: "There was no contact at all.. He [supervisor] sent some 
flowers." (Employee4) This employee reported to be satisfied with this situation: "I found this very pleasant." (Employee4) After eight weeks, most employees and supervisors met regularly. One HR professional noted that particularly in case the employee has a psychological health complaint, there is a tendency not to meet early during sick leave: ".. supervisors think: 'oh, the employee suffers from burnout, that will take long', and do not keep in touch [with the employee]." (HR professional6) Some other employees and supervisors met only once during the first year: "My boss came to visit me once." (Employee2) This employee showed slight disappointment: "..I must say that I did not hear anything from my boss in that phase [early during sick leave].." (Employee2)

Generally, employees and supervisors did not exchange information about possibilities for work resumption. Most employees only informed their supervisors about their medical recovery: "I have always kept them informed." (Employee6) This employee noted that the supervisor did not undertake action either to exchange information: "He [supervisor] did not make any effort to get to know my situation." (Employee6)

None of the employees and supervisors mutually decided about the employees' work resumption. Employees who resumed work within one year, usually consulted their care professionals or OPs: "My OP advised to start working again.." (Employee4)

The organisations offered the services of an OP to their employees early during sick leave: "We only offer an OP." (HR professional6) This HR professional reported not to purchase RTW interventions such as a comprehensive RTW trajectory for employees early during sick leave.

\section{Supervisors use their power and decide about RTW during the second year of sick leave}

The degree of cooperation was moderate during the second year (Table 2). Now, all employees and supervisors met regularly. One HR professional noted: "You have to stay in touch with the employee.." (HR professional6)

Similar to the first year, employees and supervisors did not exchange information about return to work possibilities later during sick leave.

Supervisors used their power and decided about the employees' RTW, without consulting the employees. These supervisors decided for their employees to either resume work immediately or the employers would dissolve their labour contracts after two years of sick leave. The supervisors based their decision on the OP's estimation of whether the employees would be employable within the next few weeks. An HR professional noted: "An employer does not benefit from an employee that cannot move around [is not employable]." (HR professional1)

Further, HR professionals reported that the organisations purchased professional interventions "to help the employee resume work at another organisation." (HR professional5) This, for example, was coaching to find a new job. These professional interventions were offered only in case the labour contract would be dissolved. 
Understanding cooperation or the lack thereof (research question 2)

Table 3 describes the factors related to 'understanding cooperation'.

Table 3. Understanding cooperation

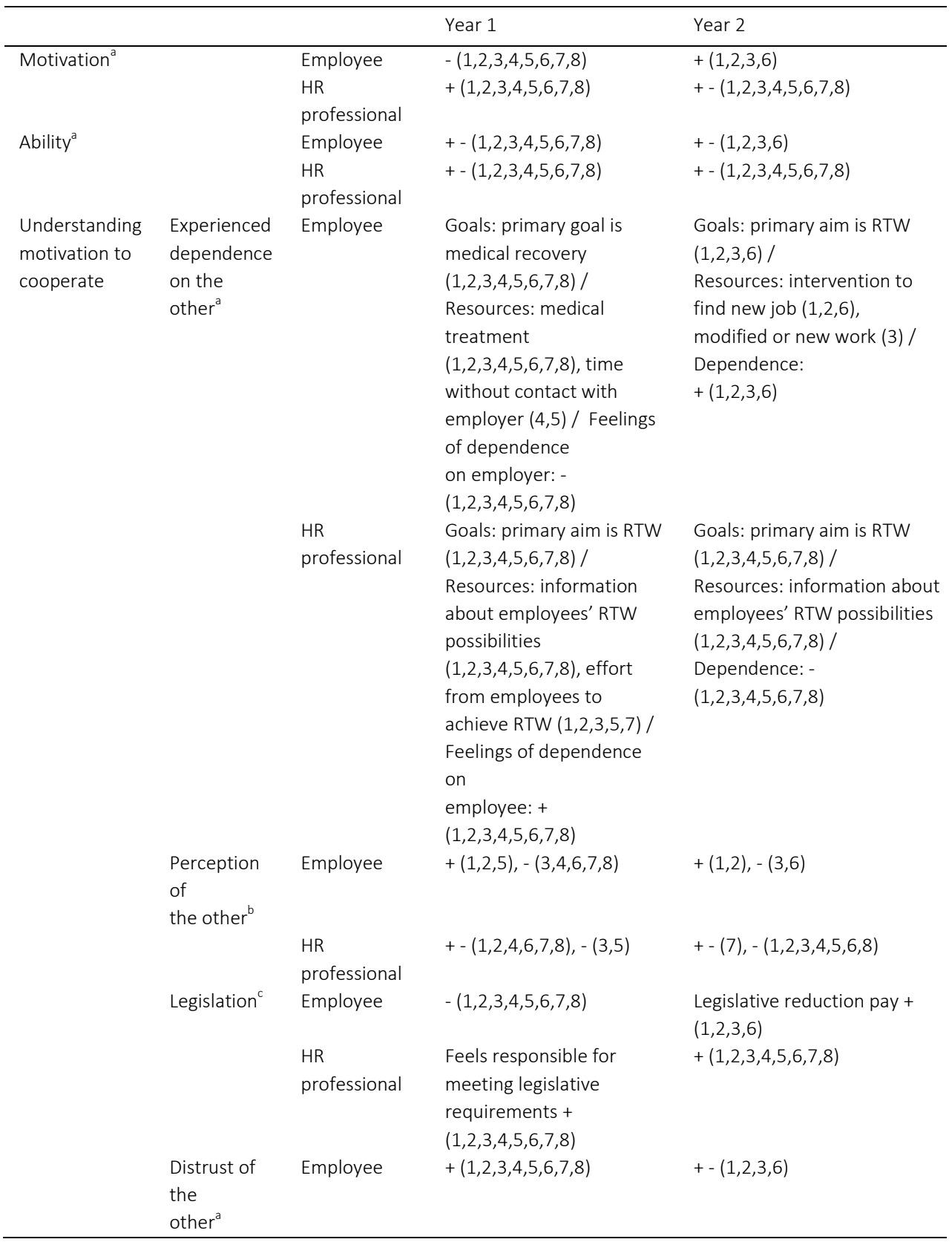




\begin{tabular}{|c|c|c|c|c|}
\hline & & & Year 1 & Year 2 \\
\hline & & $\begin{array}{l}\mathrm{HR} \\
\text { professional }\end{array}$ & - $(1,2,3,4,5,6,7,8)$ & $+(1,2,3,4,5,6,7,8)$ \\
\hline & $\begin{array}{l}\text { Norms } \\
\text { about } \\
\text { the goals }\end{array}$ & Employee & $+(1,2,3,4,5,6,7,8)$ & $+(1,2,3,6)$ \\
\hline & & $\begin{array}{l}\mathrm{HR} \\
\text { professional }\end{array}$ & $+(1,2,3,4,5,6,7,8)$ & $+(1,2,3,4,5,6,7,8)$ \\
\hline \multirow{4}{*}{$\begin{array}{l}\text { Understanding } \\
\text { ability to } \\
\text { cooperate }\end{array}$} & Legislation $^{c}$ & Employee & - $(1,2,3,4,5,6,7,8)$ & $-(1,2,3,6)$ \\
\hline & & $\begin{array}{l}\mathrm{HR} \\
\text { professional }\end{array}$ & $\begin{array}{l}\text { Legislation supports } \\
\text { planning meetings + } \\
(1,2,3,4,5,6,7,8)\end{array}$ & - $(1,2,3,4,5,6,7,8)$ \\
\hline & Resources $^{\mathrm{e}}$ & Employee & $\begin{array}{l}\text { Time to meet }+ \\
(1,2,3,4,5,6,7,8) \text {, } \\
\text { knowledge of law }+(1) /- \\
(2,3,4,5,6,7,8) \text { feeling well } \\
\text { enough - }(1,5,6)\end{array}$ & $\begin{array}{l}\text { Time to meet }+(1,2,3,6) \text {, } \\
\text { knowledge of decision } \\
\text { discretion regarding RTW - } \\
(2,3,6)\end{array}$ \\
\hline & & $\begin{array}{l}\mathrm{HR} \\
\text { professional }\end{array}$ & $\begin{array}{l}\text { Time, place to meet + } \\
(1,2,3,4,5,6,7,8) \text {, policy, } \\
\text { budget }+(1,2,3,4,8) / \text { - } \\
(5,6,7) \text {, communicative } \\
\text { skills - }(1,2,3,4,5,6,7,8) \text {, } \\
\text { knowledge about } \\
\text { information employers } \\
\text { are allowed to ask } \\
\text { employees for - } \\
(1,2,3,4,5,6,7,8)\end{array}$ & $\begin{array}{l}\text { Time, place to meet }+ \\
(1,2,3,4,5,6,7,8), \\
\text { communicative skills - } \\
(1,2,3,4,5,6,8), \\
\text { policy, budget }+(1,2,3,4,8) / \\
\text { - }(5,6,7)\end{array}$ \\
\hline
\end{tabular}

\footnotetext{
a + high, + - moderate, - low.

${ }^{b}+$ positive, + - neutral, - negative.

${ }^{c}+$ high degree of favourability, + - moderate favourability, - low favourability.

${ }^{d}+$ norms about the timing of medical recovery and RTW are experienced.

e has resource, - lacks resource.
}

It appeared that (the lack of) cooperation can be understood by A) the employees' and supervisors' (lack of) motivation to cooperate regarding work resumption, and B) employees and supervisors were not completely able to cooperate. Again, we see differences between the first and second year of sick leave, which were important for understanding the cooperation between employees and supervisors.

\section{(Lack of) motivation to cooperate}

Early during sick leave, employees reported to lack the motivation to cooperate: ".. I did not want any contact." (Employee4) Supervisors, on the other hand, felt highly motivated to cooperate. An HR professional noted: "We aim to meet an employee early during sick leave." (HR professional1) As opposed to this first year, the supervisors' motivation to cooperate declined later during sick leave. Employees, however, reported 
that they became highly motivated to comply with the actions undertaken by supervisors. "I am happy that my employer offered the opportunity to do temporary work." (Employee1)

Below, the factors are described that appear to be important for understanding the employees' and supervisors' motivation to cooperate: lack of experienced dependence on each other for achieving medical recovery (employee) or RTW (HR professional and supervisor), positive and negative mutual perceptions, legislation stimulates particularly the supervisor (first year) or the employee (second year), distrust and norms about the employees' and HR professionals' goals (Table 3).

\section{Lack of experienced dependence on each other for achieving medical recovery (employee) or RTW (HR professional and supervisor)}

Employees primarily focused on medical recovery during the first year of sick leave. The focus of cooperation shifted towards RTW during the second year of sick leave. Employees did not feel dependent on the employers for achieving medical recovery early during sick leave, while HR professionals and supervisors tended not to feel dependent on the employees for achieving RTW later during sick leave.

\section{Year 1: employees focus strongly on medical recovery and health care professionals}

Employees primarily focused on their medical recovery early during sick leave: "I find it very important to improve my condition." (Employee1) They believed that: "You can resume work only after finishing all the hospital-related things." (Employee7) As a result, employees considered medical treatment to be important for supporting their medical recovery. They focused on their health care professionals rather than their supervisors. "I have benefited greatly from the psychologist." (Employee5) An employee who had psychological complaints noted the importance of social support for medical recovery as well: "My coach provided theoretical support. My partner, daughter and friends supported me on the level of me as a person." (Employee4) These employees felt a tension in relation to their supervisors as they considered time without any contact with the supervisor an important condition for medical recovery. One employee explained: "[In case of more contact with the supervisor]: '..I would have resumed work way too early. That would have made me even more ill than I already was." (Employee4)

In contrast to the employees (who primarily aimed for medical recovery), the HR professionals reported that supervisors aim primarily at their employees' work resumption "because they [the supervisors] [have to] keep an eye on the financial aspect." (HR professional1) Especially supervisors at SMEs thought that work resumption was urgent because, to them, sick leave was a considerable financial burden: "It [employees' sick leave] costs a lot and the work does not get done." (Employee2) HR professionals reported that they aimed to support the employees to resume work during their medical recovery: "One does not have to wait [with RTW] until the employee is feeling completely healthy." (HR professional2) They attached much 
value to the efforts made by their employees to achieve RTW. HR professionals reported that another important condition for achieving RTW was having "..an overview of the RTW possibilities." (HR professional3) This HR professional noted that knowledge about RTW possibilities may help to decide about actual RTW.

\section{Year 1: employees control cooperation}

$\mathrm{HR}$ professionals reported to feel a tension in relation to their employees. "Some employees even say that they do not understand that we contact them.." (HR professional5) HR professionals reported that supervisors experience difficulty to communicate with the employees about their RTW: "Creating understanding of the employer's situation.. that can be difficult." (HR professional1) Ultimately, the employees controlled cooperation; i.e. the supervisors and HR professionals adapted to the employees' wish not to discuss RTW as they considered medical recovery to be a "personal process." (HR professional6) This HR professional thought that one should not contact the employee unnecessarily during the medical recovery process.

\section{Year 2: focus of cooperation shifts towards return to work}

Compared to the first year of sick leave (during which medical recovery was the central focus), the focus of cooperation shifted to return to work later during sick leave. This shift was also paralleled by tensions between the employees and HR professionals.

Employees often finished their medical treatment later during sick leave, or had tried multiple medical treatments. HR professionals tended to feel annoyed about not achieving RTW (the employer's primary goal): "(about an employee) The employee received colour therapy, bereavement care, holistic therapy, about everything that exists. He received it all and kept on being sick- listed until we finally said: 'we do not accept this any longer'." (HR professional8) One HR professional noted that this tension between aiming for medical recovery and aiming for RTW may result in a conflict: "[About the most common source of a conflict in his organisation] An employee who thinks that he cannot work yet, while we think that he can." (HR professional3)

\section{Year 2: HR professionals and supervisors control cooperation}

$\mathrm{HR}$ professionals felt that they had more influence on the situation than employees later during sick leave: "We tend to steer it." (HR professional5) HR professionals usually used their relatively powerful position to make employees to return to work: "[About a conflict with employees] I clearly explain what I expect them to do.. than they are normally fine with that." (HR professional4) Other HR professionals may threaten employees: "You risk us not paying you wages anymore.." (HR professional6) (Dutch employers can ask the social insurance office for permission to stop wage payment if employees do not cooperate in trying to achieve RTW). Actions undertaken by $H R$ professionals had effect, because most employees thought that their job was at risk. An HR professional noted: "Employees think: they want to dump me." (HR professional1) 
These employees felt that they should put more effort into RTW. Consequently, RTW became the most urgent goal to them: "I need to have an income." (Employee6) The employees felt dependent on their supervisors for modifying or renewing their tasks. One employee mentioned: "Receptionist.. . that is a job they would never offer." (Employee6)

HR professionals, on the other hand, no longer felt comfortable waiting for the employees. "I want a solution." (HR professional8) The HR professionals considered a professional's opinion about the employees' RTW possibilities to be important: "Let the OP determine that." (HR professional3) In the end, the supervisors usually decided about the employees' RTW themselves (immediate work resumption or dissolving the labour contract after two years of sick leave). One employee told that he was disappointed: "I always enjoyed my work." (Employee6) One employee noted: "I am just grateful that they pay me my wages." (Employee6) This employee felt that he could not influence the supervisors' decision.

\section{Positive and negative perceptions of each other}

Some employees viewed their supervisors positively during the first year of sick leave. "She is very supportive." (Employee1) Others were sceptical about their supervisors' personal qualities. "He cannot communicate." (Employee6) Most HR professionals did not have an outspoken positive or negative perception of their employees. However, some HR professionals considered their employees "very passive" (HR professional5) in realising their own RTW.

The employees' positive or negative perceptions of their supervisors remained unchanged during the second year. Most HR professionals, however, had a negative perception of employees during the second year of sick leave. One HR professional complained about employees saying: "It [return to work] does not quite work out." (HR professional8) This HR professional noted that some employees did not actively aim to return to work.

Legislation stimulates particularly the supervisor (first year) or the employee (second year) Legislation also supported the employees' and supervisors' motivation to cooperate. Again, there were major differences between the first and second year of sick leave. Generally, legislation supported particularly the supervisor (first year) or the employee (second year). This is explained below.

Year 1: supervisors felt responsible for meeting legal requirements on cooperation

Both employees and HR professionals reported that they considered supervisors to be responsible for meeting the standards as set by law early during sick leave. For example, employees in general regarded supervisors responsible for contacting them or modifying their work. One employee noted: "he [the supervisor] would be held responsible [by the social insurance office] if I could not resume work." (Employee2) 
Additionally, particularly the HR professionals told that they were afraid of being sanctioned for not meeting legal requirements. "The social insurance office assesses the employer's efforts in supporting RTW and imposes sanctions. I do not think employees are judged so strictly." (HR professional5) In fact, employees and supervisors who met each other only once did so because it was prescribed by law. "We at least have to make an action plan for RTW." (HR professional5)

\section{Year 2: legal reduction in pay stimulates employees to cooperate}

Employees received a legally sanctioned reduction in pay and became aware that the two-year period of sick leave had almost expired: "I started to realise that there is much at stake." (Employee6) This employee thought that because of sick leave, he may eventually lose his job and thus cooperation with the supervisor became more important.

\section{Distrust}

Some HR professionals emphasised the importance of trust in employee-supervisor relations: "In case employees trust their supervisors, there will be more open communication during sick leave." (HR professional6) Another advantage of trust was noted as well: "..both can deal easily with work-related issues [making work adaptations]." (HR professional4) Nevertheless, during both years of sick leave, employees and supervisors experienced distrust. Distrust may have two different consequences: either avoiding meetings and exchange of information about RTW (employees, year 1 ) or planning the meetings that are required to abide by Dutch legislation (supervisor, year 2).

\section{Year 1: Employees may distrust their supervisors}

Employees experienced not to trust their supervisors (completely) early during sick leave. One employee explained: "Of course my supervisor does not truly care about me. But that is inherent to his position." (Employee2) Both employees and HR professionals recognised that a violation of trust before sick leave can be the reason of sick leave: " $A$ conflict in the workplace can even turn into sick leave." (HR professional1) One employee explained: "I told my supervisor that I had too much work. He did not agree. And there it all began.. [about the reason for sick leave].. frustration of the past years. I was so angry at my work.." (Employee3) This employee also mentioned: "My supervisor still does not recognise that he made a mistake." (Employee3) The violation of this employees' trust before sick leave, still played a role during sick leave.

Year 2: HR professionals' trust in employees may be violated because of sick leave Later during sick leave, the HR professionals' trust tended to be violated because of sick leave. One HR professional explained: "..we indeed distrust an employee.. anyone can say that his general practitioner told that he should not work." (HR professional3) This 
HR professional seems to think that the employee did not do everything he could do to resume work.

An HR professional told about the consequences of a lack of trust in employees: "Than I can be really strict.." (HR professional5) These HR professionals planned the meetings that are required to abide by legislation. One HR professional noted: "We are obliged to keep searching for RTW possibilities." (HR professional6) This HR professional mentioned to be afraid of being sanctioned for not doing enough to achieve the employees' RTW. Thus, the legislation stimulated the HR professionals to use their power for realising cooperation regarding the employees' RTW.

\section{Norms about the employees' and HR professionals' goals}

The employees aimed to resume work after medical recovery, while HR professionals aimed to help the employees resume work during medical recovery. These goals seem to be affected by one's norms regarding medical recovery and work resumption. HR professionals noted that the social environment and care professionals may affect the employees' personal norms about medical recovery and work resumption: "The employees' partner and friends often say: 'stay at home'." (HR professional3) "If a surgeon tells that an employee cannot work, he will not work." (HR professional4) The HR professionals felt stimulated by OPs or by research findings: "Research shows that employees with psychological complaints should return to work within a couple of weeks.." (HR professional2). This HR professional experienced a norm to aim for the employees' work resumption during medical recovery.

\section{Perhaps motivated, yet not completely able to cooperate}

Employees and supervisors had a moderate degree of ability to cooperate during both years of sick leave. One HR professional noted: "Supervisors are not entirely 'equipped' to support sick-listed employees." (HR professional4)

Several factors may help to understand the employees' and supervisors' moderate degree of ability, which are: time- and feeling well enough to meet, knowledge, communication skills, policies and money to support the employees' work resumption and legislation. Generally, employees and supervisors possessed some aspects (such as time to meet) and lacked others (such as knowledge of the legislation). Below, an overview is given per aspect.

\section{Time- and feeling well enough to meet}

Generally, employees and supervisors experienced to have enough time to meet. One HR professional noted "You need to make time for such meetings." (HR professional5) However, some employees noted that they did not feel well enough to meet their supervisors early during sick leave: "I felt so bad, I could only stay in bed." (Employee5). This may have inhibited these employees to cooperate with their supervisors. 


\section{Knowledge}

One employee reported to know the legislative prescriptions about the employees' role in RTW and noted: "..this may be because I work at an HR department." (Employee1) However, most employees told that they did not know the legislation about return to work: "I do not know if my RTW process proceeds according to some legislation." (Employee4)

Generally, supervisors did not know whether they were allowed to ask employees about their medical recovery if the employees did not bring this subject up themselves (Dutch legislation does not permit employers to ask about the medical diagnosis of sick employees). One HR officer noted that in their organisation, there are supervisors who do not at all know what to do in case an employee calls in sick: ".. [to some supervisors] I explain everything from the legislation to the agreements made with the occupational health service, step by step." (HR professional3) Some employees noticed that their supervisors lacked knowledge of psychological complaints: "My supervisor keeps asking what productivity he can expect from me. He does not recognise that the course of a psychological complaint is erratic." (Employee 4)

In those cases in which the supervisor decided about RTW, employees did not know their decision latitude. The employees thought that: "In the end it is the OP who decides" (Employee2) (Dutch legislation allows employees and employers to decide on RTW, the OP has an advisory role only).

\section{Communication skills of supervisors}

Particularly the HR professionals spoke negatively about the supervisors' communicative skills. HR professionals noted that supervisors find communication particularly difficult in case the employees suffered from psychological complaints: "[about the reason why supervisors do not always succeed to discuss limitations in workrelated functioning] There still is a taboo on psychological complaints.. Employees may be hesitant to talk about their situations" (HR professional6) These supervisors' lack of communicative skills may relate to their lack of training in supporting employees on long-term sick leave: "..In our organisation, supervisors cannot not take part in trainings about dealing with sick leave. Only HR professionals are trained" (HR professional4) Overall, these supervisors' lack of communicative skills may have inhibited them to cooperate with the employees.

\section{Policies and budget to support the employees' work resumption}

Some organisations lacked an extensive sick leave policy and budget to support the employees' work resumption: "We do not have a social worker or a psychologist." (HR professional6) This may have inhibited the supervisors' possibilities to offer professional interventions. One employee noted that he was disappointed "Some organisations pay for meditation courses or other support. They [employer] should have offered me something like that." (Employee8) Thereby, the organisation's sick leave policy and 
budget to support absent employees may have affected the cooperation between absent employees and their supervisors.

\section{Legislation supported the HR professionals and supervisors to plan meetings with employees}

An HR professional explained how legislation helped him and the supervisors to plan meetings with employees: "We hand out pamphlets [to employees] about the law [and what it says]. Most employees then understand why we have to plan meetings." (HR professional5) As the last quote shows, the HR professional used legislative guidelines to convince their employees of the necessity of meeting.

The internal validity of the RDIC model (research question 3)

Table 4 describes the expected degrees of cooperation, motivation and ability (which are defined based on the underlying level in the RDIC model) and the observed degrees of cooperation, motivation and ability (reported by employees and HR professionals).

Table 4. The validity of the RDIC model

\begin{tabular}{llllll}
\hline & & \multicolumn{2}{c}{ Year 1 } & \multicolumn{2}{c}{ Year 2 } \\
\cline { 3 - 6 } & & Expected & Observed & Expected & Observed \\
\hline Cooperation & & - & - & +- & +- \\
Motivation & Employee & $+-/-$ & - & $+/+-$ & + \\
Ability & HR professional & $+/+$ & + & +- & +- \\
& Employee & - & +- & - & +- \\
& HR professional & + & +- & - & +- \\
\hline
\end{tabular}

Note. + high, + - moderate, - low.

As can be seen in Table 4, the expected degrees of cooperation matched with the observed degrees of cooperation regarding both years of sick leave (first year: low degree, second year: moderate degree of cooperation, see answer to research question 1). Further, in some cases, there was a full fit between the expected and experienced degrees of motivation. This fit existed in case the employee reported a negative perception of the supervisor and in case the HR professional reported no outspoken positive or negative perception of the employee during the first year of sick leave. During the second year, there was a match between the observed and expected degrees of motivation in case the employee reported a positive perception of the supervisor and in case the HR professional either did not report an outspoken perception of the employee or experienced a negative perception. Finally, there was no full fit between the expected and observed degrees of ability. The expected degree of ability was low in employees and high in HR professionals, whereas both employees and HR professionals reported a moderate degree of ability during the first year of sick 
leave. During the second year of sick leave, a low degree of ability was expected, while both employees and HR professionals experienced a moderate degree of ability.

Table 3 describes an additional factor that is not part of the RDIC model, which is the employees' and HR professionals' distrust. Finally, Table 3 describes the employees' and HR professionals' norms about the goals of medical recovery (employees' primary goal) and RTW (HR professionals' primary goal). We did not include personal norms in the version of the RDIC model that we used in this study (see Figure 1).

\section{Discussion}

This study aimed to describe and understand cooperation between Dutch sick-listed employees and their employers (in this study, the employer was represented by the HR professional) and to analyse the internal validity of the RDIC model. We conducted indepth interviews with three complete cases (i.e. employee and employer), five single employees and five single employers.

Overall, the results of the qualitative analyses showed that the degree of cooperation was low during the first and moderate during the second year. Particularly employers were motivated to cooperate during the first year, while employees were more motivated during the second year. This could be understood by experienced dependence; employees (first year) and employers (second year) tended not to consider their cooperation to be important for achieving medical recovery (employees) or RTW (employers). These goals may be understood by personal norms about the timing of medical recovery and work resumption. Legislation was particularly effective with the employers during the first year and the employees during the second year. Employees tended to distrust their employers during the first, while employers experienced to distrust the employees during the second year. Besides, employees and employers experienced a moderate ability to cooperate. This could be understood particularly by having moderate knowledge about the legislation.

\section{Discussion of the results}

Our study has illustrated the importance of legislation. It may enforce a minimum cooperation between employees and employers - when all else has been tried and proven insufficient. For example, the legislation may stimulate the employers to use their power to plan meetings with the employees. Thus, as was also reported in the paper of de Rijk et al. (2007) - applied to the workers' council- legislation can give employers their 'teeth' [3]. Still, the full potential of cooperation seems often not to be reached. It appears that for an adequate cooperation, employees and employers particularly need to 'be aware of their mutual dependence', 'trust each other' and 'have 
knowledge about the legislation'. Moreover, the price of distrust is paid and might negatively influence the further relations between employee and employer.

\section{Awareness of a mutual dependence for achieving medical recovery and RTW}

Our results illustrate that early in absence, employees were motivated to cooperate with employers only if the employers allowed them to focus mainly on medical recovery (the employees' primary goal). Later, however, employers were motivated to cooperate mainly for achieving RTW (the employers' primary goal). Employees, and some employers may consider it impossible to achieve medical recovery and RTW simultaneously, which generates a certain competition instead of cooperation [3].

In fact, several studies published in the last decade have shown that symbiotic dependence, by means of which employees and employers help each other to achieve both medical recovery and RTW simultaneously, is most effective and beneficial (a winwin situation). If employees and employers cooperate in modifying work tasks and attaining RTW, they benefit in terms of health (the employees; see [1,25]), and early and sustainable RTW (from which the employers benefit; see $[4-7,26]$ ).

Professionals such as OPs may make the employees and employers aware of their mutual dependence for achieving their own goals (employees: medical recovery/employers: RTW). Our analysis showed that the employees' and employers' goals are influenced by the norms regarding medical recovery and work resumption. Therefore, professionals need to be aware of the role of the norms held by for example employees' family or care professional about the timing of RTW in relation to the medical recovery process. Intervention studies may also focus on the employees' and employers' awareness of their mutual dependence. Researchers involved in the present study will develop and test professional support (including coaching of employees and employers).

\section{Trust}

Distrust stimulated employers to plan the meetings that are required to abide by the legislation. At first sight, distrust may be functional, i.e. result in more meetings. However, our findings also showed that in these meetings, particularly the employers tended to pursue their self-interests. For example, the employers often decided themselves about the employees' RTW. Some employees appeared to be disappointed about the employers' decision. A cooperation based on mutual trust might have resulted in a more adequate work resumption. Ståhl mentions trust as a key condition for effective cooperation in work resumption [4].

To enhance trust, professionals such as OPs may stimulate employees and employers to communicate about matters of trust and support them to acknowledge each other's role in the work resumption process. Empowerment of employees is another way to get more influence in the unequal relationship with the employer. 
However, this appears to be difficult and ambiguous because it may have excluding consequences for employees who cannot fulfil the expectations [27].

\section{Knowledge of the legislation}

The study results illustrate that employees and employers considered employers to be responsible for meeting the standards set by law, while officially they are both responsible. The employees' and employers' lack of knowledge of the Dutch law causes the law to be sub-optimally effective in increasing cooperation. As our study has shown, employees often waited for their employer to take action.

The above illustrates that employees and employers not only need to be motivated, but must also be able to cooperate. Professionals such as HR officers should inform the employees and supervisors about the legislation and develop local protocols accessible through the internet based on the legislation.

Internal validity of the RDIC model

The RDIC model helped to understand cooperation between Dutch sick-listed employees and their employers. However, there was a mismatch between the expected and observed patterns of the employees' and employers' ability to cooperate. For example, employers who did and those who did not feel effects of the legislation experienced a similar ability to cooperate. Possibly, the employers felt the practical resources to be more important for understanding the ability to cooperate than the legislation. Further, the mutual perceptions differed among cases from positive or neutral to negative. According to the RDIC model, actors only feel dependent on each other for acquiring a resource if they perceive each other positively enough [3]. At this point, our data is not in line with the theory. The data show that despite the employees' and employers' negative perceptions, they may still feel dependent on each other. Also, in some cases there was a mismatch between the expected and observed degrees of motivation to cooperate. The degrees of motivation were similar in employees and employers with positive, neutral or negative mutual perceptions. Possibly, the legislation and feelings of dependence on each other for achieving ones goals are more important for understanding the motivation to cooperate than the perceptions. Distrust may also play a role. For example, our findings showed that distrust stimulated employees to avoid cooperation with their employers.

Although we focussed on the legislation, we also found evidence for norms playing a role. Strong norms regarding RTW exist [4] and thus, this seems a factor of importance. 


\section{Study limitations}

This study has limitations. First, we did not succeed in gathering a sample consisting only of complete cases (i.e. employee and employer). Some employers who participated in our study refused to give referrals to an employee. This might be because the employers did not know a person whom they expected to be willing to give an interview. It may also be related to distrust, which would support our finding that the cooperation between employees and employers is often paralleled by distrust.

No immediate supervisors have been interviewed on the employers' side; only human resource officers and managers. Most human resource officers and managers had extensive experience with supporting employees on long-term sick leave. They were not involved in early, successful RTW. Their selective experience with work resumption may have coloured the human resource officers' and managers' perceptions of employees somewhat. Also, some employees interviewed had resumed work (but not more than one year ago). These employees were interviewed retrospectively. A retrospective interview may yield different results than an interview at the time of sick leave.

We interviewed three complete cases. These complete cases did not yield extra information compared to the other interviews, although one case enabled us to verify statements of the employee and employer against each other. This lack of additional information could be explained by the process of our data collection: we interviewed the employers before the employees. We asked the employers to talk about their experiences with sick-listed employees in general (and not about specific cases). At the end of the interviews with the employers, we asked for a referral to an employee. This employee was asked to talk about his/her situation.

The employees that we interviewed were not highly motivated to return to work quickly, which may be related to our inclusion criterion that employees had to be on sick leave for at least 6 weeks. We also noticed a tendency among employers to provide socially desirable answers, and some of them only gave referrals to employees whom they expected to speak positively about them. This can be considered an argument against the use of complete cases only. The lack of motivation to cooperate in RTW might thus in many cases be even more problematic than the data suggest - which would actually reinforce our results.

In this study, we applied the method of pattern matching to analyse the degree of cooperation and to study the validity of the RDIC model for understanding the cooperation between Dutch absent employees and their employers [23]. As part of this method, we quantified concepts such as cooperation using the interview data and documents about the legislation. It is difficult to quantify concepts based on qualitative data. Despite of this limitation, pattern matching supports a systematic and thorough analysis of the fit of a model to the data. Therefore, it appears to be an appropriate analytic strategy for this study. 


\section{Conclusions}

Our findings illustrate that legislation can ensure a minimum cooperation between employees and employers (only if this legislation includes rules regarding cooperation). However, legislation alone is not enough to achieve adequate cooperation between sick-listed employees and their employers. Awareness of a mutual dependence on each other for achieving their own goals (employees: medical recovery / employers: RTW), trust and enough knowledge about the legislation are important. Moreover, personal norms regarding medical recovery and RTW play a role in the employees' and employers' primary goals (employees: medical recovery / employers: RTW). Professionals such as OPs may support these factors to attain a degree of cooperation that is necessary to establish effective RTW.

\section{Abbreviations}

OP: Occupational physician;

RDIC model: Resource Dependence Institutional Cooperation model;

RTW: Return to work;

SMEs: Small and medium enterprises. 


\section{References}

1. Black C. Working for a healthier tomorrow. London: TSO; 2008.

2. Annesley C. Lisbon and social Europe: towards a European 'adult worker model' welfare system. J Eur Soc Policy. 2007;17:195-205.

3. De Rijk A, Van Raak A, Van der Made J. A new theoretical model for cooperation in public health settings: the RDIC model. Qual Health Res. 2007;17:1103-1116.

4. Ståhl C. In Cooperation We Trust. Interorganizational Cooperation in Return-To-Work and Labour Market Reintegration. Linköping: Linköping University, National Centre for Work and Rehabilitation; 2010.

5. Anema JR, Schellart AJ, Cassidy JD, Loisel P, Veerman TJ, Van der Beek AJ. Can cross country differences in return-to-work after chronic occupational back pain be explained? An exploratory analysis on disability policies in a six country cohort study. J Occup Rehabil. 2009;19:419-426.

6. Arnetz BB, Sjörgen B, Rydéhn B, Meisel B. Early workplace intervention for employees with musculoskeletal-related absenteeism: a prospective controlled intervention study. J Occup Environ Med. 2003, 45:499-506.

7. Bültmann U, Sherson D, Olsen J, Lysbeck Hansen C, Lund T, Kilsgaard J. Coordinated and tailored work rehabilitation: a randomized controlled trial with economic evaluation undertaken with workers on sick leave due to musculoskeletal disorders. J Occup Rehabil. 2009;19:81-93.

8. Karlson B, Jönsson P, Pålsson B, Åbjörnsson G, Malmberg B, Larsson B, Österberg K. Return to work after a workplace-oriented intervention for patients on sick leave for burnout - a prospective controlled study. BMC Publ Health. 2010;10:301.

9. Fleten $\mathrm{N}$, Johnsen $\mathrm{R}$, Førde O. Length of sick leave - Why not ask the sick-listed? Sick listed individuals predict their length of sick leave more accurately than professionals. BMC Publ Health. 2004;4:46.

10. Friesen MN, Yassi A, Cooper J. Return-to-work: the importance of human interactions and organizational structures. Work. 2001;17:11-22.

11. Lysaght RM, Larmour-Trode S. An exploration of social support as a factor in the return-to-work process. Work. 2008;30:255-266.

12. Labriola M. Conceptual framework of sick leave and return to work, focusing on both the individual and the contextual level. Work. 2008;30:377-387.

13. Reijenga FA, Veerman TJ, Van den Berg N. Onderzoek evaluatie wet verbetering poortwachter [Evaluation of the Improved Gatekeeper Act]. Leiden: AStri; 2006.

14. Brouwer P, Hessels J, Te Peele A, Westhof F. Grenzen aan verantwoordelijkheid. Begeleiding en reïntegratie van zieke werknemers in het MKB [Boundaries on responsibility. Support and reintegration of sick employees in SMEs]. Zoetermeer: EIM onderzoek voor Bedrijf en Beleid; 2003.

15. Van Duijn M, Miedema H, Elders L, Burdorf A. Barriers for early return-to-work of workers with musculoskeletal disorders according to occupational health physicians and human resource managers. J Occup Rehabil. 2004;14:31-41.

16. Overheid.nl. Wet Verbetering Poortwachter [Improved Gatekeeper Act]. http://wetten.overheid.nl/BWBR0013063/geldigheidsdatum_05-04-2012.

17. Evers HGJ. De Wet Verbetering Poortwachter. Handleiding voor de praktijk [The improved Gatekeeper Act. A practice guideline]. Deventer: Kluwer Juridisch; 2007.

18. Van der Meer HCB, Willems JHBM. Taken en verantwoordelijkheden van de bedrijfsarts in het kader van de verzuimbegeleiding en re-integratie [Tasks and responsibilities of the occupational physician in sick leave and return to work counselling]. Utrecht: KNMG-Consult; 2009.

19. Maiwald K, De Rijk A, Guzman J, Schonstein E, Yassi A. Evaluation of a workplace disability prevention intervention in Canada: examining differing perceptions of stakeholders. J Occup Rehabil. 2011;21:17989.

20. Stone D. Policy paradox: the art of political decision making. New York: Norton; 2002.

21. Tyler TR. Why people cooperate: the role of social motivations. New Jersey: Princeton University Press; 2011. 
22. Polit D, Beck CT. Nursing Research: Generating and Assessing Evidence for Nursing Practice. 8th edition. Philadelphia: J.B. Lippincott; 2008.

23. Yin R. Case study research: design and methods. London: Sage; 1994.

24. Boeije HR. Analysis in qualitative research. London: Sage; 2010.

25. Waddell G, Burton AK. Is work good for your health and well-being? London: TSO; 2006

26. Anema JR, Steenstra IA, Bongers PM, De Vet HC, Knol DL, Loisel P, Van Mechelen W. Multidisciplinary rehabilitation for subacute low back pain: graded activity or workplace intervention or both? A randomized controlled trial. Spine. 2007;32:291-98.

27. Van Hal LBE, Meershoek A, Nijhuis F, Horstman K. The 'empowered client' in vocational rehabilitation: the excluding impact of inclusive strategies. Health Care Anal. 2012;20:213-230. 
CHAPTER 5

A process evaluation of a return-to-work intervention to improve cooperation between sick-listed employees and their supervisors (COSS)

Hoefsmit N, Boumans N, Houkes I, Nijhuis FJN

Submitted 


\section{Abstract}

Purpose: This is a process evaluation of an intervention to improve COoperation regarding return-to-work (RTW) between Sick-listed employees and their Supervisors (COSS: conversation roadmap, monitoring of cooperation (using questionnaires as an assessment instrument) and, if necessary, extra occupational physician (OP) support. Research questions were: 1) How was COSS adopted by the organisation? 2) How was cOSS implemented among individual employees, supervisors and OPs?

Method: We used quantitative data (online questionnaire, project administration, conversation minutes, emails) and qualitative data (semi-structured interviews). We used descriptive analyses of the quantitative data. Qualitative data were analysed datadriven.

Results: The organisations' representatives reported positively (e.g. fit with existing policy) and negatively (e.g. high intensity) about COSS. At least one OP (out of five) used the monitoring information. Project administration data show a modest reach of COSS among employees and supervisors. The roadmap was used by a minority. Relatively many were satisfied with COSS as a tool to evaluate conversations with the employee/supervisor afterwards. Interview results indicate that the roadmap was considered useful in specific situations (e.g. psychological complaints). All employees and supervisors participated in the monitoring. The majority received- and was satisfied with OP support. Having sufficient time to use COSS is an example of a precondition for the intervention.

Conclusions: Despite the good adoption of COSS by the organisation, it was only partially implemented by professionals, employees and supervisors. We hypothesize that our implementation approach did not fit completely with the culture at the bank. Also, the results illustrate the need for better intervention instruments (e.g. something else than a questionnaire) and a more specific target population. 


\section{Introduction}

Early return-to-work (RTW) after sick leave is important to increase sustainable participation. Employees are considered to benefit in terms of health and quality of life, while employers gain financially [1]. However, there are many bottlenecks in the cooperation between sick-listed employees and their supervisors [2-5]. Based on former studies [5-7], five bottlenecks were identified. First, there is no planned- and/or time contingent approach of their meetings [5]. Though, research has shown that early intervention is effective for all employees and time contingent interventions, gradual RTW or taking a decision about RTW are effective for employees with physical complaints [6]. Second, there is a lack of open communication between employees and supervisors/HR professionals about RTW [5,7]. Third, employees and supervisors/HR professionals tend not to take joined decisions about employees' RTW (e.g. supervisors/HR professionals may decide on their own) [5,7]. Fourth, employees and supervisors/HR professionals do not feel symbiotically dependent for their primary goals (employees: medical recovery / supervisors/HR professionals: RTW) [5]. Strict norms and beliefs play a role in these goals (employees: RTW after medical recovery, HR professionals: RTW during recovery) $[5,7]$. Fifth, there is distrust between employees and supervisors/HR professionals [5].

Resolving these bottlenecks may facilitate employees' RTW. Surprisingly, few RTW interventions involve supervisors. One of the few interventions we found focused on burned out employees and included a convergence dialogue between the employee and the supervisor. This intervention improved RTW after 1.5 and 2.5 years of follow up (the latter for younger participants only) [8-9]. To our knowledge, there is no such intervention that is generic, i.e. for all employees regardless their diagnoses, which is accessible via the workplace. Generic interventions at organizational level are important for the Netherlands because Dutch supervisors are not allowed to ask employees about their diagnoses.

Based on the studies mentioned above, we developed such a generic intervention to improve the COoperation between Sick-listed employees and their Supervisors (COSS). This article reports on a process evaluation of COSS in a Dutch banking organisation.

Description of the intervention (COSS)

We developed COSS for the Dutch situation in which the Improved Gatekeeper Act prescribes employees and employers to cooperate in RTW (for example, to write an action plan for RTW). Employers should pay at least 70\% of the income during two years of sick leave [10-11]. Nevertheless, cooperation still appears to be sub-optimal in practice, for example because of distrust between employees and supervisors/HR professionals [5]. 
COSS aims to improve Cooperation between Sick-listed employees and their Supervisors. It consists of a 'conversation roadmap' to structure and intensify their cooperation. A second component is the monitoring of the quality of cooperation (using an assessment instrument that consists of questionnaires focused at bottlenecks A-E mentioned earlier, filled out by employees and supervisors) at: the start of COSS, in week eight of sick leave and every twelfth week thereafter until complete RTW. When employees and supervisors started COSS in e.g. the sixth week of sick leave, they did not receive the second monitoring. Based on our analysis of these questionnaires, we advised OPs (who were trained) about improving the cooperation. Appendix 1 of this thesis describes COSS in more detail.

The current study: a process evaluation

An effect- and economic evaluation of COSS were described elsewhere [12-13]. It is important to understand under which conditions COSS is (in)effective in order to formulate recommendations [14-16]. We performed a process evaluation among the intervention group of the field study, using quantitative and qualitative data. Following several innovation theories and models, we focused on the adoption (attitude towards innovation) and implementation (in daily routines) [17-20]. Our research questions were: 1) How was COSS adopted by the organisation? 2) How was COSS implemented among individual employees, supervisors and OPs?

\section{Method}

Design

COSS was studied in a large Dutch bank. We based our process evaluation on data triangulation (quantitative: online questionnaire, project administration, conversation minutes, emails; as well as qualitative: semi-structured interviews). This study included multiple stakeholders (i.e. organisation's representatives; OPs, employees, supervisors). According to Dutch law, our study did not require ethical committee approval (correspondence dd. 7 November 2011, registration number: METC 11-4-115/Dutch trial register: 3151).

\section{Measures and population}

Table 1 describes the evaluation topics, stakeholders and measurements per research question. 
Table 1. Data collection for the process evaluation

\begin{tabular}{|c|c|c|c|c|}
\hline $\begin{array}{l}\text { Research } \\
\text { question }\end{array}$ & Topic & Stakeholder & $\begin{array}{l}\text { Variables and } \\
\text { concepts }\end{array}$ & Method for data collection \\
\hline 1 & Adoption & $\begin{array}{l}\text { A) } R \\
\text { B) } E, S\end{array}$ & $\begin{array}{l}\text { A) Sick leave policy, } \\
\text { attitude towards } \\
\text { innovation } \\
\text { B) Frequency-, type- } \\
\text { and content of } \\
\text { stakeholder contacts }\end{array}$ & $\begin{array}{l}\text { A) Semi-structured interview, example item: 'What } \\
\text { did you expect of COSS before adoption?' (R1-R2) } \\
\text { B) Semi-structured interview, example question: } \\
\text { 'Was there contact with the absent employee?' }\end{array}$ \\
\hline \multirow[t]{5}{*}{2} & Reach & $\begin{array}{l}\text { A) E who used } \\
\text { COSS } \\
\text { B) E who } \\
\text { refused COSS }\end{array}$ & $\begin{array}{l}\text { A) E invited for- and } \\
\text { used COSS (based on } \\
\text { [15]) } \\
\text { B) Reasons for non- } \\
\text { participation }\end{array}$ & $\begin{array}{l}\text { A) Researchers ' project administration } \\
\text { B) Minutes about telephone conversations E as } \\
\text { part of recruitment of participants in COSS }\end{array}$ \\
\hline & Use & $E, S$ & $\begin{array}{l}\text { Using the roadmap, } \\
\text { participation in } \\
\text { monitoring and extra } \\
\text { OP support (based } \\
\text { on [15]) }\end{array}$ & $\begin{array}{l}\text { - Roadmap: Online questionnaire, example item: } \\
\text { 'Did you use the guidelines in the roadmap to } \\
\text { prepare conversations?' Semi-structured } \\
\text { interview, example question: 'Did you use the } \\
\text { conversation agenda?' (E1-E4, S1-S2). } \\
\text { - Monitoring: Researchers' administration } \\
\text { - OP support: online questionnaire, example item: } \\
\text { 'Did you receive OP support?' Semi-structured } \\
\text { interview, example question: 'Did you receive OP } \\
\text { support?' (E1-E4, S1-S2) }\end{array}$ \\
\hline & $\begin{array}{l}\text { Satisfac- } \\
\text { tion }\end{array}$ & $E, S$ & $\begin{array}{l}\text { Satisfaction (based } \\
\text { on [15]) }\end{array}$ & $\begin{array}{l}\text { - Online questionnaire, example item: 'To what } \\
\text { degree was the support (i.e. roadmap: preparation } \\
\text { for conversations) useful in your situation?' } \\
\text { (dichotomised for analysis) } \\
\text { - Semi-structured interview, example question } \\
\text { 'How did you experience the OP?' (E1-E4, S1-S2) }\end{array}$ \\
\hline & Context & $E, S$ & $\begin{array}{l}\text { Preconditions (based } \\
\text { on [15]) }\end{array}$ & $\begin{array}{l}\text { - Semi-structured interview, example question: } \\
\text { 'What were preconditions for COSS?' (E1-E4, S1- } \\
\text { S2) }\end{array}$ \\
\hline & Fidelity & OP & $\begin{array}{l}\text { Carrying COSS out } \\
\text { per protocol, i.e. } \\
\text { intervention delivery } \\
\text { by OP (based on [15]) }\end{array}$ & $\begin{array}{l}\text { - Semi-structured interview, example question: } \\
\text { 'Did you receive the monitoring reports?' (O1-O2) } \\
\text { - Email contact with OP, example question: 'How } \\
\text { often did you provide extra support based on the } \\
\text { reports?' }\end{array}$ \\
\hline
\end{tabular}

Note: $\mathrm{E}=$ employee, $\mathrm{S}=$ supervisor, $\mathrm{O}=\mathrm{OP}, \mathrm{R}=$ representative of the organisation

We collected quantitative data about reach, use, satisfaction and fidelity. We collected qualitative data to gain insight in participants' attitudes and/or experiences regarding the adoption, use, satisfaction, context and fidelity.

Table 2 describes the study samples. 
Table 2. Population- (online questionnaire) and participant characteristics (semi-structured interviews)

\begin{tabular}{|c|c|c|c|c|}
\hline \multicolumn{5}{|c|}{ Population characteristics (online questionnaire) } \\
\hline Characteristic & \multicolumn{2}{|l|}{ Employee $(\mathrm{N}=29)$} & \multicolumn{2}{|c|}{ Supervisor ( $N=32)$} \\
\hline Age & \multicolumn{4}{|c|}{ Mean $=45.8$ years $(S D=8.7)$} \\
\hline Gender & \multicolumn{2}{|c|}{ Male $(N=10)$ / Female $(N=19)$} & \multicolumn{2}{|c|}{ Male $(N=14) /$ Female $(N=18)$} \\
\hline \multicolumn{5}{|c|}{ Participant characteristics (semi-structured interviews) } \\
\hline Characteristic & $\begin{array}{l}\text { Employee } \\
(\mathrm{N}=4)\end{array}$ & $\begin{array}{l}\text { Supervisor } \\
(N=2)\end{array}$ & $\begin{array}{l}\mathrm{OP} \\
(\mathrm{N}=2)\end{array}$ & $\begin{array}{l}\text { Representatives } \\
\text { organisation } \\
(\mathrm{N}=2)\end{array}$ \\
\hline $\begin{array}{l}\text { Type of health } \\
\text { complaints }\end{array}$ & $\begin{array}{l}\text { Psychological (1), } \\
\text { physical (3) }\end{array}$ & Not applicable & Not applicable & Not applicable \\
\hline Age & $\leq 50(1) />50(3)$ & $\leq 50(2)$ & $\leq 50(2)$ & $>50(2)$ \\
\hline Gender & $\begin{array}{l}\text { Male (1) / female } \\
\text { (3) }\end{array}$ & Male (2) & Female (2) & Male (2) \\
\hline Absence duration & $\begin{array}{l}2 \text { months (3) / } 4 \\
\text { months (1) }\end{array}$ & Not applicable & Not applicable & Not applicable \\
\hline Profession & $\begin{array}{l}\text { Facility employee } \\
(2), \text { interim } \\
\text { manager (1), } \\
\text { Assistant account } \\
\text { manager (1) }\end{array}$ & $\begin{array}{l}\text { Manager private } \\
\text { banking (2) }\end{array}$ & $\mathrm{OP}(2)$ & $\begin{array}{l}\text { Process manager } \\
(1), \text { coordinating } \\
\text { OP (1) }\end{array}$ \\
\hline
\end{tabular}

Note: $\mathrm{E}=$ employee, $\mathrm{S}=$ supervisor, $\mathrm{O}=\mathrm{OP}, \mathrm{R}=$ representative of the organisation

In total 29 employees and 32 supervisors filled out the questionnaire and 10 participants gave a semi-structured interview.

\section{Procedure}

Interview participants were recruited from the intervention participants using convenience sampling [21]. Employees and supervisors were invited by email and phoned by $\mathrm{NH}$ afterwards. We included employees who had resumed work or supervisors who supported employees who had resumed work. All interviews (30 minutes each) took place ten months after the start of COSS. We interviewed two OPs, but we were also interested in whether the other three participating OPs provided extra support and thus we emailed them (and if needed, send out reminder mail(s)).

We emailed an access code to an online questionnaire about the use of- and satisfaction with cOSS to employees and supervisors after the employees' RTW. If needed, we send out reminder mail(s).

$\mathrm{NH}$ built the project administration during the implementation of COSS. Every change in participant status was filed (drop out, questionnaires completed).

We also made minutes of phone calls with employees sick-listed for two to three weeks (during the recruitment for COSS). 
First, we transcribed the semi-structured interviews and analysed them data-driven [22]. We searched for consistent and meaningful fragments (open coding). Then, we abstracted, defined and delineated concepts and decided about their relevance (axial coding). We made constant comparisons between and within cases to refine concepts before themes were defined and applied researcher triangulation (frequent discussion) [22].

We dichotomised questionnaire data (only where items were not dichotomous already) and analysed it descriptively with IBM SPSS Statistics for Windows, Version 22.0. Further, we analysed project administration data by counting employees who were invited for- and used COSS. We counted and summarised information regarding the reach and fidelity of COSS in the conversation minutes and emails.

\section{Results}

Research question 1: adoption

The organisation's representatives reported positive and negative attitudes towards coss.

Regarding the positive attitudes, a representative noted that COSS's aim fitted well to the organisation's policy. ".. we increasingly paid attention to how the OP can coach the supervisor.." (representative 1)

Further, this representative noted: ".. you incorporated our suggestions (into COSS).. this made that I wanted to go for it in the management team.." (representative 1) The representative reported satisfaction about the cooperation with the research team.

The representatives also reported negatively towards COSS. The roadmap and the monitoring of the cooperation could imply a lot of work for supervisors: "Then, it (intervention) becomes a burden.." (representative 2)

Besides, providing COSS was said to be complex as "..many actors are involved.." (representative 2) There would be a risk of failure.

Further, they doubted that COSS would be supported by the organisational culture, in which employees were used to little top-down regulation of their work. "Employees are usually provided with many ideas.. only few are obligatory.." (representative 1) The representatives doubted that every employee and supervisor would be interested in COSS, as this was not the case with the organisations' sick leave policy (which, e.g., recommends meetings between employees and supervisors). "In case.. this (sick leave) takes longer, than I think that people will be curious." (representative 1) Regarding 
COSS, a representative noted: "We can only try to convince them (employees and supervisors) of how helpful it may be." (representative 1) The organisation did not impose policy on employees and supervisors.

Finally, a representative reported to lack an overview of stakeholder contacts in RTW, which made it difficult to estimate whether employees and supervisors would need COSS. Table 3 describes those contacts during the execution of COSS, as reported during the semi-structured interviews by employees, supervisors and OPs.

Table 3. Contacts between stakeholders in RTW based on the interviews with 4 employees and 2 supervisors

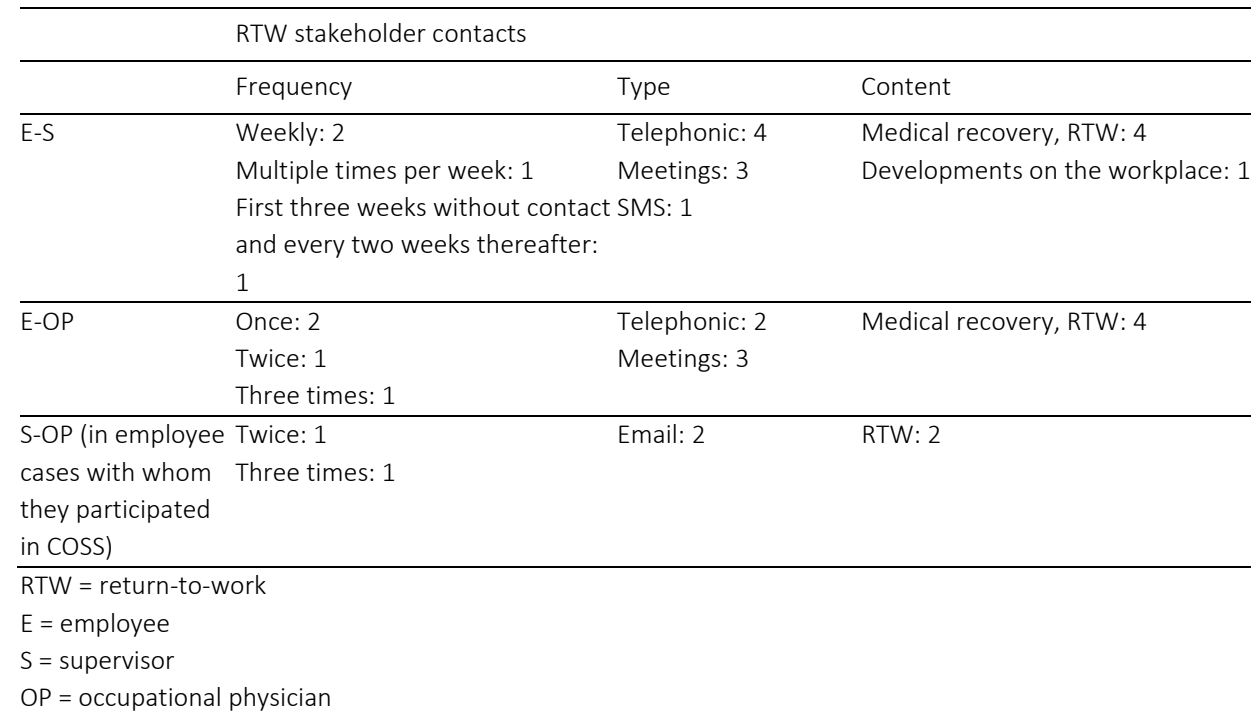

Most employees and supervisors had at least weekly contact. Employees usually had contact with OPs. Supervisors had two or three contact moments with the OP.

Research question 2: implementation

\section{Reach}

In total 549 invitations were sent to employees sick-listed for five or ten working days. A considerable part of these invitations were sent to employees who already returned to work, were about to resume work or were not sick-listed in the first place. So these employees were not eligible for participation in COSS. For another considerable part, we do not know their reasons for (non-) participation, for example because we could not contact them. A minority of the employees refused to participate for reasons such as feeling too ill or a lack of trust in the confidential treatment of questionnaire data. In total, 39 employees filled out the first monitoring questionnaire for coss and were 
included (some employees and supervisors received log in information for the questionnaire but were excluded later on, e.g. because of being terminally ill).

\section{Use}

The online questionnaire results regarding the use of COSS are displayed in Table 4.

Table 4. Results regarding the implementation: use of- and satisfaction with COSS

Use and satisfaction with roadmap (questionnaire data) and use of monitoring (project administration data)

$\begin{array}{llll}\text { Roadmap } & \text { Roadmap } & \text { Roadmap } & \text { Monitoring } \\ \text { (preparation } & \text { (meeting agenda) } & \begin{array}{l}\text { (evaluation } \\ \text { cheetings) }\end{array} & \text { questionnaire(s) } \\ & & \end{array}$

\begin{tabular}{|c|c|c|c|c|c|}
\hline Use & $E(N=29)$ & 10 & 5 & 5 & 29 \\
\hline $\begin{array}{l}\text { Satis- } \\
\text { faction }\end{array}$ & $\begin{array}{l}\text { E who used } \\
\text { intervention } \\
\text { part }\end{array}$ & 3 (out of 10 ) & 1 (out of 5) & 2 (out of 5 ) & \\
\hline Use & $S(N=32)$ & 8 & 6 & 3 & 32 \\
\hline \multirow[t]{2}{*}{$\begin{array}{l}\text { Satis- } \\
\text { faction }\end{array}$} & $\begin{array}{l}\text { S who used } \\
\text { intervention } \\
\text { part }\end{array}$ & 3 (out of 8 ) & 3 (out of 6) & 3 (out of 3 ) & \\
\hline & & \multicolumn{4}{|c|}{$\begin{array}{l}\text { Average grade roadmap among those who used it } \\
\text { (on 10-point scale): } \\
\text { E: } 6.9(S D=1.2) / S: 6.3(S D=1.2)\end{array}$} \\
\hline
\end{tabular}

\begin{tabular}{|c|c|c|c|c|c|c|c|c|}
\hline \multirow[t]{2}{*}{ Use } & \multirow[t]{2}{*}{$\begin{array}{l}E(N=29) \\
S(N=32)\end{array}$} & \multicolumn{7}{|c|}{$\begin{array}{l}28 \text { received OP support } \\
26 \text { received OP support }\end{array}$} \\
\hline & & $\begin{array}{l}\text { OP } \\
\text { enhanced } \\
\text { trust E-S }\end{array}$ & $\begin{array}{l}\text { OP } \\
\text { stimulated } \\
\text { cooperation } \\
\text { E-S }\end{array}$ & $\begin{array}{l}\text { OP } \\
\text { supported } \\
\text { E to } \\
\text { achieve } \\
\text { RTW }\end{array}$ & $\begin{array}{l}\text { OP } \\
\text { stimulated } \\
\text { control } \\
\text { over RTW } \\
\text { decision }\end{array}$ & $\begin{array}{l}\text { OP acted } \\
\text { inde- } \\
\text { pendently }\end{array}$ & $\begin{array}{l}\text { Trust } \\
\text { in } \\
\text { OP }\end{array}$ & $\begin{array}{l}\text { Satisfaction } \\
\text { with OP }\end{array}$ \\
\hline \multirow[t]{2}{*}{$\begin{array}{l}\text { Satis- } \\
\text { faction }\end{array}$} & $\begin{array}{l}\text { E who } \\
\text { received } \\
\text { OP } \\
\text { support } \\
(\mathrm{N}=28)\end{array}$ & 13 & 24 & 26 & 23 & 10 & 25 & 24 \\
\hline & $\begin{array}{l}\text { S who } \\
\text { received } \\
\text { OP } \\
\text { support } \\
(\mathrm{N}=25)^{*}\end{array}$ & 12 & 22 & 23 & 17 & 15 & 24 & 22 \\
\hline
\end{tabular}

Note. The results regarding satisfaction were dichotomised prior to analysis.

$\mathrm{OP}=$ occupational physician. $\mathrm{E}=$ employee. $\mathrm{S}=$ supervisor.

* Of the 26 supervisors who received OP support, 25 filled out the questions about satisfaction with the OP. 
Of the three parts of the roadmap (preparation, conversations, evaluation), the preparation for conversations was used mostly (employees: 34.5\%, supervisors: $25 \%$ ). All 39 employees and supervisors participated in the monitoring at the start of COSS. For 26 cases, 1 or 2 more monitoring reports were sent to the OPs later during sick leave. In total $96.6 \%$ of the employees and $81.3 \%$ of the supervisors who filled out the online questionnaire, received OP support.

Of the interview participants half reported to use the roadmap (i.e. 2 employees and 1 supervisor). None of them received extra OP support (based on the monitoring).

\section{Satisfaction}

The questionnaire results (Table 4) show that relatively many employees (40\%) and supervisors (100\%) who used the roadmap were satisfied with the evaluation guidelines in the roadmap. They were less often satisfied with the roadmap as a tool for preparingand agenda setting for meetings. Overall, $85.7 \%$ of the employees and $88.0 \%$ of the supervisors were satisfied with the OP. Less than half of the employees and supervisors indicated that the OP enhanced their mutual trust. Also, $35.7 \%$ of the employees and $60.0 \%$ of the supervisors thought that the OP acted independently.

It appeared from the interviews that employees and supervisors considered the conversation roadmap to be useful in some situations and in others less useful.

First, employees and supervisors differed regarding whether they considered the concept of a roadmap to be appealing. Some employees were enthusiastic: "It is a handy tool." (employee 3) This employee liked the stepwise approach: "..both the employee and the supervisor fill out their own roadmap and compare afterwards." (employee 3) Supervisors, however, considered the roadmap too administrative: "I do not want a lot of extra administration activities." (supervisor 1). This supervisor noted: "The risk is that it (roadmap) becomes a checklist.." (supervisor 1) The supervisor thought that the roadmap may provoke superficial conversations about RTW.

The experiences with COSS also varied with the types of health complaints. In case of psychological complaints, the roadmap helped to structure the RTW process: "I used to forget what I said within a day. That is why I wrote everything down (in the roadmap).." (employee 3) The roadmap facilitated the employee to agree with the supervisor on RTW: "We only had to follow the steps.." (employee 3) In contrast, a supervisor evaluated the roadmap as less useful for employees with physical- and/or less severe health complaints: "She had a brace. Still, she could use her other arm.. It (roadmap) becomes a burden if it is over the top for the health complaint." (supervisor 1) This supervisor thought that in this case, the roadmap would only imply extra work.

The clarity of the medical prognosis was considered relevant. The roadmap was regarded as useful in case of an unclear prognosis. "It (roadmap) gave me the feeling that I still focused on RTW." (employee 2) Once the prognosis was clear, the employee 
stopped using the roadmap: "..the wound needed to heal and I had to start exercising again." (employee 2)

The degree of mutual trust also played a role. An employee told how the roadmap may help in case of a lack of trust: "..the roadmap may give instructions to employees on how to deal with the supervisor." (employee 4). A supervisor noted: "If one experiences a problem with an employee, then one wants to do this (roadmap).. to build documentation." (supervisor 1 ) Both supervisors noted that documentation might limit the risk of a financial sanction by the social insurer after two years of absence (i.e. an extra year of wage payment in case of insufficient effort to support RTW). ".. one can say: we agreed to do this, but she (employee) does not want to (resume work)." (supervisor 1)

However, in case of mutual trust, the roadmap was considered to be less useful. "I have a good relation with my employees, so that they will tell about their issues openly." (supervisor 2) This supervisor thought that the employees' open communication would facilitate RTW. We also interviewed the employee of this supervisor, who noted: "I am lucky with a supervisor who empathizes a lot with what happens.. My supervisor actually knows everything of me." (employee 3) The employee confirmed the supervisor's experience.

Further, whether contact between the sick-listed employee and the supervisor comes about spontaneously was considered relevant. An employee noted about situations where contact does not come about: "..it (roadmap) could be quite good (to initiate contact)." (employee 1)

In contrast, an employee who had spontaneous contact with the supervisor noted: ".. I did not see a reason to use it." (employee 4)

Further, the supervisor's experience with supporting absent employees played a role. The roadmap was considered useful in case the supervisor lacked experience: "We did not know what to discuss. The roadmap provided us with ideas." (employee 2) A supervisor mentioned: "It is not always easy to discuss the essence of the problem.." (supervisor 2) This supervisor had a lot of experience in supporting absent employees: "If one empathizes with the employee, one does not need the roadmap.." (supervisor 2) This quote illustrates the supervisor's self-confidence in supporting absent employees.

Finally, the flexibility in the use of the conversation roadmap played a role. The roadmap recommends that employees and supervisors evaluate their conversation separately, before the next conversation. It went well in case employees and supervisors fitted the roadmap to their own situations: "During meetings we discussed the questions (in the roadmap). During the next meeting, we evaluated the previous one." (supervisor 2) In contrast, an employee who literally followed all steps experienced an issue: ".. we thought that we should hurry up. There is a timeline in the roadmap.." (employee 2) Thus, if used flexibly, the roadmap was considered more useful than in case the steps were followed strictly. 


\section{Context}

The interviewed employees and supervisors noted preconditions for COSS. A supervisor reported to need time to use the roadmap: ".. which is often lacking.." (supervisor 2)

An employee mentioned the importance of receiving the roadmap in time: "..because of the timeline (of activities in the roadmap)." (employee 2)

A supervisor reported the need for motivation: ".. commitment to use it." (supervisor 2) An employee thought that OPs should make employees aware of the importance of the roadmap: "The OP did this with me." (employee 3)

An employee noted: ".. I could not use the computer. ..I could also not use this (COSS)" (employee 1) It is possible to use coss only when the employee's health complaint allows it.

\section{Fidelity of extra OP support}

We interviewed two OPs. One used the reports about the quality of cooperation. "I discussed the information with the employee." (OP 2) This OP was satisfied: "The reports were very clear.." (OP 2) Yet, the reports did not describe which issues (e.g. a lack of trust) were experienced by whom. "Then (when improved) I would know whether I have to advise the employee, the supervisor or both." (OP 2)

The other OP reported: "I did not use them (the reports)." (OP 1) This OP experienced that the information often did not match with the OPs own impression of the situation: "You often stated that this (OP action) was not needed. Meanwhile, supervisors asked for a lot of support." (OP 1) Yet, this OP thought that the reports focused on the employees' employability instead of inability: '..that was very appealing.." (OP 1)

Finally, one OP replied to our email about the fidelity to COSS and mentioned not to provide this support.

\section{Discussion}

This study aimed to describe the adoption and implementation of COSS, an organisational RTW intervention to improve cooperation between absent employees and their supervisors. Despite its good adoption by the organisation, it was only partially implemented by OPs, employees and supervisors. Several factors can explain these results.

The first explanation may have to do with the misalignment of the implementation approach and the organisational culture. The culture at the bank is characterised by a high level of professional autonomy and little top-down pressure to comply with the sick leave policy. Consequently, there is freedom for employees and supervisors to decide about actions to take during sick leave and they may experience a considerable amount of self-direction already. These employees and supervisors probably do not 
expect that they can benefit much from an intervention to promote self-direction. Particularly given the lack of steering and control from the top at the bank, a high degree of non-compliance with coss can come about.

Although the researchers engaged in bottom-up implementation activities (e.g. visits to several local offices of the bank), coss was implemented mostly top-down. This implementation approach was chosen in agreement with the bank and seemed to be the most appropriate one at the start of this project. However, it can be taken from the above that this approach has been too much top-down for this organisation [23].

A second explanation, to some extent linked to the first is that our findings suggest that supervisors were not convinced of the added value of COSS. These supervisors reported to have extensive experience with supporting absent employees (which suggests that they developed their own style and procedures) and hence, they would not need COSS. Alternately, they did not consider sick leave an important management task. Research also shows that managers postpone actions related to RTW interventions [24]. Sick leave guidance costs a lot of time for supervisors, which may be intensified by coss. In general, our findings illustrate how difficult it is to change professionals.

Further, we found that the extra OP support related to COSS (in addition to the regular OP support) was hardly provided. An OP noted that the monitoring reports deviated from the OP's own perception of the cooperation. Also, OPs may have ignored COSS as they may have perceived COSS as a threat to their professional autonomy [2526]. COSS standardises the evaluation of the cooperation between employees and employers and hence partially takes over the OP role.

Moreover, employees and supervisors did not always use cOSS in those situations where they could have benefited from it. For example, an employee and both interviewed supervisors mentioned that they would use the roadmap only in case of distrust. In case of trust, the roadmap was not considered to have an added value for their cooperation. The roadmap, however, was developed to prevent (not resolve) distrust, because research has shown that supervisors' distrust can arise during sick leave [5].

Also, COSS may have been too generic. Our findings show that satisfaction with coss differed with the employees' and supervisors' situations. Generally, COSS, (which is a very structured intervention), was considered particularly valuable in uncertain situations.

Finally, external factors most likely played a role. During the study, Dutch media reported about OPs who did not adequately protect employees' confidential information [27]. This, and the economic climate in which employees experience job insecurity, may have made employees feel unsafe and unwilling to participate in (research about) coss. 


\section{Methodological reflection}

For several reasons, this was a very comprehensive process evaluation. It included dataand stakeholder triangulation, which is important to acquire a complete image of a study topic [21]. Another strength is that we evaluated both COSSs' adoption and implementation. We interviewed employees with physical and psychological complaints and both men and women. Further, many employees and supervisors of the intervention group in the effect- and economic evaluation filled out the process evaluation questionnaire, which suggests that our study population was a good reflection of the intervention group. The process evaluation results are necessary to understand the results of the effect- and economic evaluation of COSS [12-13].

However, there were some limitations, particularly related to the questionnaires. First, the process evaluation questionnaire did not distinguish between regular- and extra OP support, as part of COSS. This made it difficult to have an overview of the use of- and satisfaction with the extra OP support. Consequently, our quantitative findings regarding the OP possibly refer to the regular support (not COSS). Second, with respect to the process evaluation questionnaire and the monitoring questionnaire (as part of COSS), employees and supervisors noted that the correct answering options were missing. They could not always fill out the questionnaires truthfully. This can also help to understand why the monitoring reports deviated from the OP's perception of the cooperation. Third, the monitoring questionnaire asks for sensitive information. It can be difficult to fill out such questions about a person with whom you cooperate very much and are dependent on, particularly since information is given to a third party (OP).

There also were study limitations regarding the interviews. We noticed a certain bias due to social desirability. Further, recall bias may have occurred as some employees resumed work about six months before the interview.

Further, of the employees and supervisors who filled out the process evaluation questionnaire, five indicated at the end of the questionnaire that they did not receive the roadmap. In one case it seems that the email was not addressed correctly. It remains unclear why the others did not receive the roadmap. The recipient's spam filter probably filtered out our email.

Finally, this study was performed in only one profit organization, which implies a limited generalizability to other sectors. The description of the setting and participants allows readers to evaluate the applicability of the results to their organisations though [28].

\section{Implications for practice}

Our results showed that the implementation of interventions to improve self-direction in RTW should fit with the organisational culture. Thus, projects should start with a diagnosis of this culture. Depending on the degree of professionalism of an 
organisational culture, participation of important stakeholders (i.e. employees, supervisors, OPs) may be necessary already from the beginning of intervention development, i.e. defining what important aspects are in the cooperation between sicklisted employees and their supervisors. Also, the need for a tool like coss by the stakeholders must get more attention in the starting period. In highly professional cultures, RTW interventions can be realized based on mutual professional control, i.e. reflection among professionals [29]. Leaders should focus on inspiring professionals [30]. Attention should also be paid to considering sick leave as a management task, as this is a prerequisite for interventions such as COSS (for example by organising meetings between managers to exchange best practices).

Further, our findings suggest that interventions should be generic (COSS was considered useful for a range of situations), but can best be applied in uncertain situations (i.e. psychological health complaints, unclear medical prognosis, lack of trust or spontaneous contact between employees and supervisors, lack of supervisors' experience with supporting absent employees). Overall, cooperation interventions should allow for flexibility. COSS can be further developed into a toolbox with parts of coss to be used as intervention instruments that can be applied by employees and supervisors. They themselves can decide about what tools to apply, depending on the needs of the situation.

Moreover, the monitoring questionnaire should be replaced by an interview by the $\mathrm{OP}$. Although it requires a time investment, an interview allows more space to employees and supervisors to provide in-depth and situation-specific information [21]. Such information can also facilitate the OPs' role in COSS. Also, an interview gives more room for the OPs' professional autonomy.

Finally, it is important to inform employees and supervisors about situations (such as in case of mutual trust) where coss can be very useful, despite that they may not expect that. Moreover, employees and supervisors should be informed about the confidentiality of interventions such as COSS as this may encourage them to participate.

\section{Implications for research}

Methods such as responsive evaluation or action research can be useful to acquire a more complete picture of an intervention in practice, especially in a more participative procedure [28,31]. Responsive evaluation is based on negotiation and focuses on the claims, concerns and issues of stakeholders. In multiple 'circles' stakeholders' own constructions of reality are taken into account in the evaluation. In the end, consensus must be reached [28]. Action research is a cyclic process of observation, reflection, planning and acting regarding change. Its strength is a cooperation between researchers and practice professionals [31].

These methods strengthen a process evaluation with stakeholder triangulation but rule out most of the limitations mentioned in the methodological reflections paragraph. 


\section{Acknowledgements}

The authors wish to thank the Dutch Foundation 'Stichting Instituut Gak-SIG' for providing funding for this study. We also thank the organisation and the study participants.

\section{Informed consent}

All procedures followed were in accordance with the ethical standards of the responsible committee on human experimentation (institutional and national) and with the Helsinki Declaration of 1975, as revised in 2000. Informed consent was obtained from all study participants.' 


\section{Literature}

1. Waddell G, Burton AK. Is work good for your health and well-being? London: TSO; 2006.

2. Friesen MN, Yassi A, Cooper J. Return-to-work: the importance of human interactions and organisational structures. WORK. 2001;17:11-22.

3. Wrapson W, Mewse AJ. Supervisors' responses to sickness certification for an episode of low back pain: employees' personal experiences. Disabil Rehabil. 2011;33:1728-36.

4. Lysaght RM, Larmour-Trode S. An exploration of social support as a factor in the return-to-work process. Work. 2008;30:255-66.

5. Hoefsmit N, de Rijk A, Houkes I. Work resumption at the price of distrust: a qualitative study on the return to work legislation in the Netherlands. BMC Public Health. 2013;13:153.

6. Hoefsmit N, Houkes I, Nijhuis FJN. Intervention characteristics that facilitate return to work after sickness absence: A systematic literature review. J Occup Rehab. 2012;22:462-77.

7. Hoefsmit N, Houkes I, Nijhuis FJN. Environmental and personal factors that support early return-to-work: a qualitative study using the ICF as a framework. WORK. 2014; 48:203-15.

8. Karlson B, Jönsson P, Pålsson B, Åbjörnsson G, Malmberg B, Larsson B, Österberg K. Return to work after a workplace-oriented intervention for patients on sick-leave for burnout - a prospective controlled study. BMC Public Health. 2010;10:301.

9. Karlson B, Jönsson P, Österberg K. Long-term stability of return to work after a workplace-oriented intervention for patients on sick leave for burnout. BMC Publ Health. 2014; 14:281.

10. Ministry of Social affairs and Employment. Wet verbetering poortwachter [Improved gatekeeper act]. http://www.arboportaal.nl/onderwerpen/arbowet--en--regelgeving/verzuim/wet-verbeteringpoortwachter.html. Accessed 6 March 2013.

11. Ministry of Social affairs and Employment. Ziekteverzuim van het werk [Sickness absence]. n.d. http://www.rijksoverheid.nl/onderwerpen/ziekteverzuim-van-het-werk. Accessed 6 March 2013.

12. Hoefsmit N, Houkes I, Boumans N, Noben C, Winkens B, Nijhuis FJN. The effectiveness of an intervention to enhance cooperation between sick-listed employees and their supervisors (COSS). Submitted.

13. Noben C, Hoefsmit N, Evers S, de Rijk A, Houkes I, Nijhuis F. Economic evaluation of a new organizational RTW intervention to improve cooperation between sick-listed employees and their supervisors (COSS): a field study. Submitted.

14. Durlak JA, DuPre EP. Implementation matters: A review of research on the influence of implementation on program outcomes and the factors affecting implementation. AJCP. 2008;41:327-50.

15. Linnan L, Steckler A. Process evaluation for public health interventions and research: an overview. In: Steckler A, Linnan L, editors. Process evaluation for public health interventions and research. San Francisco: Jossey-Bass; 2002. pp. 1-23.

16. Oakley A, Strange V, Bonell C, Allen E, Stephenson J. Process evaluation in randomized controlled trials of complex interventions. BMJ. 2006;332:413-6.

17. Grol R, Wensing M. Implementatie: Effectieve verbetering van de patiëntenzorg [Implementation: effective improvement of patient care]. Maarssen: Elsevier gezondheidszorg; 2006.

18. Green L, Kreuter M. Health program planning: An educational and ecological approach. 4th ed. New York: McGrawhill; 2005.

19. Kotter JP. Leading change. Boston: Harvard Business School Press; 1996.

20. Rogers EM. Diffusion of innovations. 5th ed. New York: Free Press; 1995.

21. Polit D, Beck CT. Nursing Research: Generating and Assessing Evidence for Nursing Practice. 8th ed. Philadelphia: J.B. Lippincott; 2008.

22. Boeije HR. Analysis in qualitative research. London: Sage; 2010.

23. Mintzberg H. Structure In Fives: Designing Effective Organizations. New Jersey: Prentice Hall; 1992.

24. Wrapson W, Mewse AJ. Supervisors' responses to sickness certification for an episode of low back pain: employees' personal experiences. Disabil Rehabil. 2011;33:1728-36. 
25. Berg M, Horstman K, Plass S, van Heusden M. Guidelines, professionals and the production of objectivity: standardisation and the professionalism of insurance medicine. Sociology of Health and Illness. 2000;22:765-91.

26. Dodier N. Clinical practice and procedures in occupational medicine: a study of the framing of individuals. In: Berg M, Mol A, editors. Differences in medicine. Durham: Duke university Press; 1998. pp. 53-79.

27. Agra D. De verzuimpolitie: het gebeurt recht onder je neus [The sick leave police: it happens right in front of you]. http://www.artsennet.nl/blogs/Artsennetbloggers/Dolf-Algra/Blogbericht-Dolf-Algra/136945/DeVerzuimpolitie-het-gebeurt-recht-onder-je-neus.htm. Accessed 2 July 2014.

28. Guba EG, Lincoln YS. Fourth Generation Evaluation. Newbury Park: Sage Publications; 1989.

29. de Bruijn H. Managing professionals. Abingdon, Oxon: Routledge; 2011.

30. Mintzberg H. Covert leadership: notes on managing professionals. Knowledge workers respond to inspiration, not supervision. Harvard Business Review. 1998;76: 140-7.

31. Koshy V. Action Research for improving educational practice. A step-by-step guide. 2nd ed. London: Sage publications Ltd; 2011. 


\section{CHAPTER 6}

The effectiveness of an intervention to enhance cooperation between sick-listed employees and their supervisors (COSS) 


\section{Abstract}

Background: Early return-to-work (RTW) after sick leave is considered to support employees' quality of life. Successful RTW requires adequate cooperation between absent employees and their supervisors. This study assesses the effectiveness of an intervention for COoperation regarding RTW between Sick-listed employees and their Supervisors (COSS; i.e. 'conversation roadmap', monitoring of cooperation and, if necessary, extra occupational physician support).

Methods: In this field study, employees on sick leave for 2-10 weeks, aged 18 up to and including 60, and performing paid labour for at least 12 hours per week were included. Terminally ill were excluded. Multivariate regression (correcting for baseline quality of life) was used to compare 6-months follow up data regarding quality of life between the groups. Using Cox regression analyses, time until first-, full-, and sustainable RTW was compared between groups.

Results: In total 64 employees received COSS or common practice. No significant group differences were found regarding all study outcomes. The coss group had a higher chance of work resumption than the common practice group. The hazard ratio was 1.39 for first RTW (95\% Cl: 0.81 to 2.37), 1.12 for full RTW (95\% Cl: 0.65 to 1.93) and 1.10 for sustainable RTW (95\% Cl: 0.63 to 1.95).

Conclusions: COSS has no significant effects. Yet, the results regarding work resumption show a tendency towards effectiveness. Therefore, COSS can be further developed and applied in practice. Researchers should try to prevent some limitations of the present study in future research, for instance by finding a more neutral research setting.

Trial registration: Dutch trial register 3151 


\section{Background}

Early return-to-work (RTW) after sickness absence is considered to be important for employees' health and quality of life [1]. Also, employers benefit from early return to work, particularly financially, i.e. lower costs for productivity loss, replacement and guidance of sick employees.

Despite the benefits for both parties, many employees do not return to work early. Studies have indicated that among other things, bottlenecks in the cooperation between absent employees and their employers hamper early RTW (see, for example $[2-4])$.

On three different institutional levels [5], researchers and policy makers have developed initiatives to facilitate cooperation. Examples are national legislation (e.g. in the Netherlands, [6]), regional or local policy (in Canada, [7-8]), or interventions for individual employees. An example of the latter is the workplace intervention by Karlson et al. to support communication between the employee and the supervisor, which successfully enhanced RTW at 1.5 year follow up for all participants and at 2.5 year follow up (the latter only for younger participants) [9-10]. Such interventions are typically developed for employees with specific health complaints (e.g. low back pain) and accessible through healthcare providers or insurers.

To address the bottlenecks in cooperation regarding RTW, we developed a generic (developed for all absent employees, regardless of their diagnosis) intervention that is provided at an organisational level. To the authors' knowledge, such an intervention has not yet been evaluated. A strong need for a generic workplace intervention exists since it can be applied organisation-wide, for all absent employees, even without knowing their diagnoses (note that for example, Dutch legislation does not allow supervisors to ask employees for their medical diagnosis). Our intervention is entitled 'COoperation regarding return-to-work between Sick-listed employees and their Supervisors' (COSS). The intervention consists of a 'conversation roadmap' for employees and supervisors to structure and intensify their cooperation regarding RTW, regular monitoring of the quality of their cooperation and, if necessary, special support by an occupational physician (OP) to facilitate cooperation. COSS aims to resolve several bottlenecks in the cooperation between absent employees and their supervisors (e.g. a lack of mutual trust) that were found in earlier studies [11-14]. The development, the process evaluation and the economic evaluation of coss are described elsewhere [15-16].

The present study evaluates the effectiveness of COSS, which is especially relevant for RTW professionals who aim to develop effective interventions in the Netherlands and other Western countries. The aim of this study is to detect whether COSS achieves better results concerning quality of life, first RTW (time until first progress made in working hours), full RTW (time until complete work resumption), and sustainable RTW (time until lasting complete RTW, i.e. working for four weeks without relapse in partial or complete sick leave) when compared to common practice. 


\section{Methods}

\section{Design and setting}

A field study was performed in a large Dutch banking organisation. We aimed to cluster randomise at department level. However, due to practical reasons our control group consisted of only one cluster and we chose to ignore the cluster randomisation in our analyses. According to Dutch law, our study did not require ethical committee approval (correspondence dd. 7 November 2011, registration number: METC 11-4-115/Dutch trial register: 3151).

\section{Participants}

Inclusion criteria for employees were that they had to be:

- $\quad$ on sick leave for at least 2 weeks but no longer than 10 weeks;

- aged from 18 up to and including 60 years;

- $\quad$ performing paid labour for at least 12 hours per week.

Terminally ill were excluded.

The criteria assessment was part of the baseline questionnaire. After approximately 5 weeks of sick leave on average, employees and their supervisors were included in either the common practice group or the COSS group, which received the intervention.

Inclusion took place between April 2012 and December 2013. Potential study participants were selected from all sick-leave cases at the participating organisation on the fifth or tenth working day of their sick leave. Figure 1 describes the recruitment procedures.

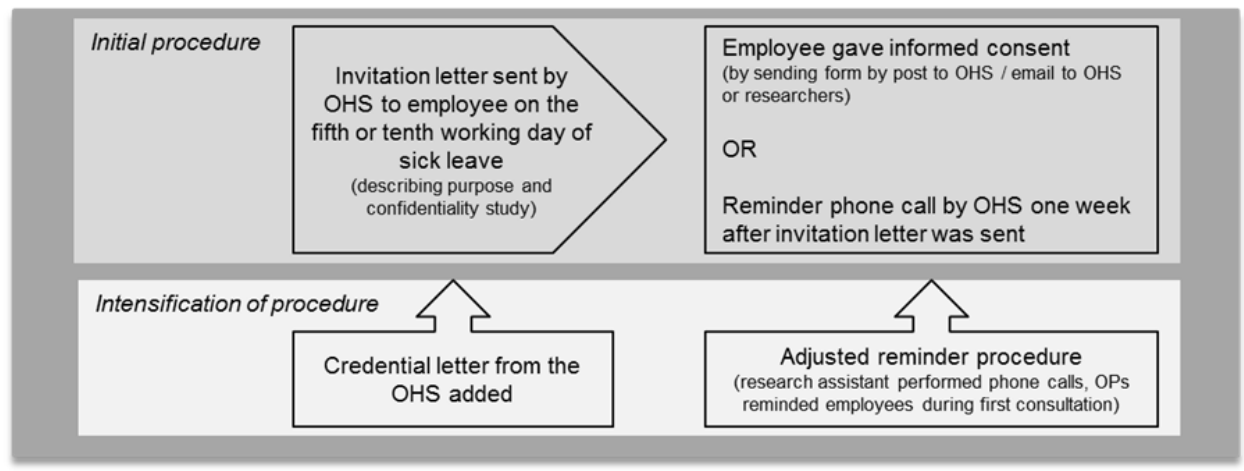

Figure 1. Recruitment procedure

Note. $\mathrm{OHS}=$ occupational health service. 
Our initial recruitment strategy did not yield a sufficient number of participants within the time span available. Therefore, the recruitment strategy was modified by intensification and adding more endorsement from the organisation (see Figure 1). A considerable part of the invited employees already returned to work, were about to resume work or were not sick-listed in the first place. Prior to the study all participants received information about the purpose and procedure of the study and all participants gave their informed consent for participation.

Sample size calculation indicated that at least 60 employees per group (COSS group and common practice group) were needed. Taking into account a dropout rate of $15 \%$, about 70 employees in each group were required. However, this calculation was based on assumptions that were not completely correct. With $\mathrm{N}=60$ employees per group, a Cohen's $d$ of 0.6 can be detected, which is a medium to large effect size [17].

\section{COSS and common practice}

Table 1 describes the support during sick leave and RTW prescribed for the COSS and common practice group.

Table 1. coss and common practice

\begin{tabular}{|c|c|c|}
\hline Common practice & & What COSS adds to common practice \\
\hline Legislation $[6,15]$ & $\begin{array}{l}\text { Organisational policy } \\
\text { in addition to legislation }\end{array}$ & \\
\hline $\begin{array}{l}\text { Legislation prescribes several } \\
\text { minimum requirements of } \\
\text { cooperation between absent } \\
\text { employee and employer such as } \\
\text { writing action plan for RTW and } \\
\text { regular evaluation of its }\end{array}$ & $\begin{array}{l}\text { First day sick leave: Telephonic } \\
\text { contact employee-supervisor on } \\
\text { first day. }\end{array}$ & $\begin{array}{l}\text { Conversation roadmap (step by step } \\
\text { plan in booklet format) to structure and } \\
\text { intensify cooperation employee- } \\
\text { supervisor. }\end{array}$ \\
\hline \multirow[t]{2}{*}{$\begin{array}{l}\text { Employee compensated by } \\
\text { employer ( } \geq 70 \% \text { income). }\end{array}$} & $\begin{array}{l}\text { Week 2-3 sick leave: Employee and } \\
\text { supervisor fill out form about, } \\
\text { among others, estimated sick leave } \\
\text { duration. Employee who is unsure } \\
\text { about the estimated sick leave } \\
\text { duration or reports psychological } \\
\text { complaints, is invited by OP. }\end{array}$ & $\begin{array}{l}\text { Monitoring quality of cooperation } \\
\text { (employee and supervisor fill out } \\
\text { questionnaires). } \\
\text { Every 4-12 weeks, research team } \\
\text { analyses results using cut-off scores. }\end{array}$ \\
\hline & $\begin{array}{l}\text { Throughout process: Weekly } \\
\text { meetings employee-supervisor. }\end{array}$ & $\begin{array}{l}\text { If necessary, based on questionnaire } \\
\text { results, extra support of cooperation } \\
\text { provided by OP. }\end{array}$ \\
\hline
\end{tabular}

Note. $\mathrm{OHS}=$ occupational health service. OP = occupational physician. In both groups, the RTW process should comply with legislation. Also, employees received support based on the organisation's (not obligatory) policy. Additionally, the intervention group received COSS, which is described in more depth elsewhere [15]. 
Outcome measures of this effect evaluation were employees' quality of life, first-, full-, and sustainable RTW. Quality of life was assessed measuring self-reported outcomes on five domains (i.e. mobility, self-care, usual activities, pain/discomfort and anxiety/depression) using the validated EuroQol 5 Dimensions 5 Levels (EQ-5D-5L, response range: 1-5) [18-19]. Both in the COSS group and common practice group, employees filled out questionnaires at baseline and at 6 months follow up. First RTW was operationalized as the time in calendar days from the first sick leave day until the first progress made in working hours. Full RTW was the time in calendar days of sick leave until complete work resumption. Sustainable RTW was the time in calendar days of sick leave until lasting complete work resumption (working for four weeks without relapse in partial or complete sick leave). We used data of the organisation's sick-leave administration for measuring the period between the start of the sick leave period wherein the employee started to participate in the study until first RTW, full RTW and sustainable RTW. This concerned a period somewhere between 23 April 2012 up to and including 7 January 2014. This implies that the follow up duration of the work resumption data varied between employees.

Additionally, by means of the baseline questionnaire, information on general characteristics was collected: education, age, gender, caring for children below 12 years of age and working hours per week.

All self-reported questionnaires were filled out electronically. When participants did not respond within one week after invitation, weekly reminders were sent by email. When participants did not respond to the reminders, they received a phone call by the university's research assistant.

Figure 2 shows the inclusion flow of the study participants.

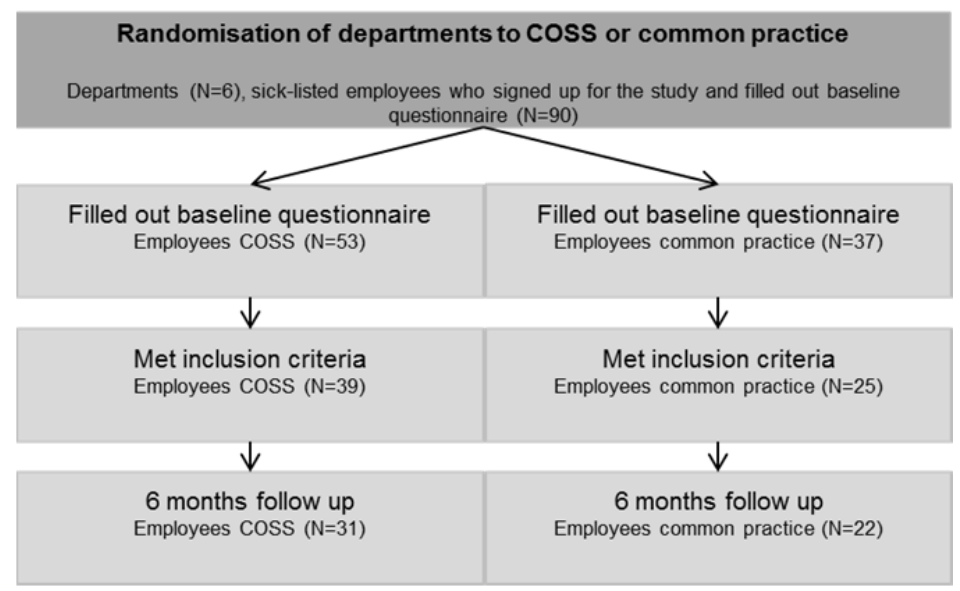

Figure 2. Study sample 
In total 64 employees were included and analysed; 39 in the COSS group and 25 in the common practice group.

\section{Analyses}

Intention-to-treat analyses (unit of analysis: employee) were performed. Quality of life index values were calculated using the EQ-5D-5L Crosswalk value set [20]. The mean score was imputed in case of missing quality of life index values and the mode was imputed where respondents indicated that their education was 'other'. In case education is bimodal, the mode score that is closest to the median will be used.

For the baseline participant characteristics, numerical variables were presented by mean (SD) and categorical ones by number (\%). Group differences in the numerical and categorical variable were tested using independent- samples t-test and $\mathrm{Chi}^{2}$ test, respectively.

Next, we presented the mean (SD) regarding the follow up of quality of life for the coss- and common practice group separately. Linear regression analysis, with correction for baseline quality of life, was performed for the outcome quality of life at follow up.

Survival analyses (Kaplan-Meier curves and Cox regression) were performed for the outcomes first RTW, full RTW and sustainable RTW. In the Cox regression, we tested the proportional hazards assumption by adding a time dependent covariate (interaction of group with time) to the model which included only group.

Sensitivity analyses were also performed. First, we repeated the linear regression analysis for the outcome quality of life in a dataset without imputations of missing quality of life index scores. Then, for both quality of life and the work resumption outcomes, we corrected for participants' characteristics that differed significantly between the COSS- and common practice group at baseline. Due to small group sizes, we added these characteristics separately to the linear- (with outcome quality of life) and Cox regression model (with outcomes first RTW, full RTW, sustainable RTW).

All analyses were performed using IBM SPSS Statistics for Windows, Version 22.0 and significance was set at a two-sided $p \leq 0.05$. 


\section{Results}

\section{Participant characteristics}

Table 2 describes characteristics of the final study sample.

Table 2. Characteristics of the study participants in the study groups

\begin{tabular}{|c|c|c|c|}
\hline Variable & COSS group $(\mathrm{N}=39)$ & $\begin{array}{l}\text { Common practice group } \\
(\mathrm{N}=25)\end{array}$ & $p$-value \\
\hline \multicolumn{4}{|l|}{ Education, N (\%) } \\
\hline Low & $5(12.82)$ & $3(12.00)$ & 0.12 \\
\hline Intermediate & $22(56.41)$ & $8(32.00)$ & \\
\hline High & $12(30.77)$ & $14(56.00)$ & \\
\hline Age, mean (sd)* & $45.31(9.17)$ & $50.60(7.44)$ & 0.02 \\
\hline Gender, N (\%)* & & & 0.01 \\
\hline Male & $14(35.90)$ & $18(72.00)$ & \\
\hline Female & 25 (64.10) & $7(28.00)$ & \\
\hline $\begin{array}{l}\text { Taking care of children } \\
<12 \text { years, } N(\%)\end{array}$ & $18(46.15)$ & $6(24.00)$ & 0.07 \\
\hline $\begin{array}{l}\text { Working hours per week, } \\
\text { mean }(s d)^{*}\end{array}$ & $31.72(6.83)$ & 35.20 (4.59) & 0.02 \\
\hline $\begin{array}{l}\text { Baseline index value } \\
\text { quality of life, mean (sd) }\end{array}$ & $0.65(0.16)$ & $0.63(0.24)$ & 0.81 \\
\hline
\end{tabular}

Note. Low education covers lower professional education, middle secondary general education. Intermediate education consists of apprenticeship or short middle professional education as well as middle professional education and secondary general education. High education covers higher professional education and academic education.

The table shows that, compared to the coss group, the common practice group was significantly older, consisted of significantly more males and worked significantly more hours per week.

\section{Quality of life}

Table 2 shows that at baseline, the mean quality of life was 0.65 (SD=0.16) in the COSS group and $0.63(S D=0.24)$ in the common practice group. At follow up, the mean quality of life index value was 0.81 ( $S D=0.10$ ) in the COSS group and $0.83(S D=0.10)$ in the common practice group. After correction for baseline in the multivariate regression analyses, there was no significant group difference (corrected mean difference: -0.02 , $95 \% \mathrm{Cl}:-0.07$ to 0.03$)$. The sensitivity analyses did not yield substantially different results. 
Figure 3 shows the Kaplan-Meier curves for the COSS- and common practice group regarding first RTW, full RTW and sustainable RTW.
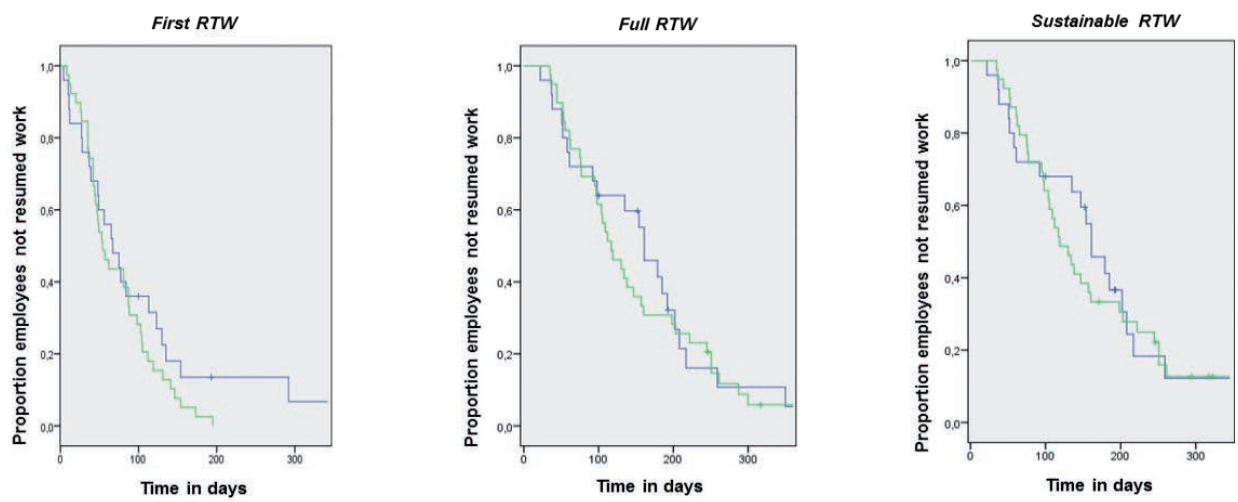

- Common practice group

- Coss group

+ Common practice group-censored

+ COSS group-censored

Figure 3. Kaplan-Meier curves for first RTW, full RTW and sustainable RTW

The curves show that between about 50 and 100 days as well as after 100 days (first RTW) and between about 100 and 200 days (full RTW, sustainable RTW) there was a smaller proportion of the employees in the COSS group on sick leave compared to the common practice group.

By means of Cox regression, we tested the proportional hazards assumption (i.e. interaction of group with time). This variable was not significant (first RTW, $p=0.13$ / full RTW, $p=0.70$ / sustainable RTW, $p=0.69$ ). Therefore, we did not include it in the final model. Cox regression analyses showed that, although not significant, the COSS group had a higher chance of work resumption than the common practice group. The hazard ratio was 1.39 for first RTW (95\% Cl: 0.81 to $2.37, p=0.23), 1.12$ for full RTW (95\% Cl: 0.65 to $1.93, p=0.68)$ and 1.10 for sustainable RTW $(95 \% \mathrm{Cl}: 0.63$ to $1.95, p=0.73)$. Finally, the sensitivity analyses regarding work resumption did not yield substantially different results.

\section{Discussion}

The aim of this study was to evaluate the effectiveness of cOSS on quality of life, first RTW, full RTW and sustainable RTW. Although no significant effects were found, the results show a trend towards a positive effect on the work resumption outcomes. 
The design of this field study was of good methodological quality, i.e. validated instrument to measure quality of life, multiple outcome measures for work resumption, objective sick leave data and advanced statistical methods. Yet, research in practice settings is complex and therefore the effect evaluation of cOSS was carried out somewhat differently than planned. In the end, both unforeseen methodological factors and factors related to the content and implementation of cOSS help to understand the lack of significant intervention effects. Yet, the lack of statistical power appears to be the main issue.

\section{Methodological explanations for the lack of significant effects}

First, although we tried multiple strategies to recruit sufficient study participants, there is a lack of statistical power. A limited statistical power implies a reduced ability to find true/significant relationships between concepts [21].

Second, the results of the process evaluation of COSS showed that employees and supervisors generally were satisfied with their OP [15], suggesting that common practice is already of good quality. Also, at the moment, sick leave in the Netherlands is at the lowest level since the year 1996 [22]. This may relate to the current economic crisis.

The study limitations described above mean that coss is tested in a not advantageous setting that very likely entails an underestimation of the actual intervention effect. This results in a very limited chance for the intervention proven to be significantly effective.

\section{Explanations related to the content and implementation of COSS}

First, there were issues related to the content of COSS. A process evaluation indicated that a questionnaire was not an adequate tool to monitor the quality of the cooperation between employees and supervisors. Also, cOSS would be particularly useful in situations characterised by uncertainty, e.g. an unclear medical prognosis or in case contact between sick-listed employees and their supervisors does not come about spontaneously [15].

Second, there was a limited implementation of COSS. The intervention was often not used during the first weeks of sick leave (i.e. the conversation roadmap was distributed by e-mail to employees and their supervisors after approximately 5 weeks of sick leave on average). Also, the process evaluation of coss revealed a limited use of coss later during sick leave as well [15]. The limited use of cOSS may have undermined the effectiveness of COSS in this evaluation. 
Overall, the methodological-, intervention- and implementation related factors described above complicate the possibilities to interpret the exact effect of coss on the outcomes measured.

\section{Conclusions and recommendations}

This project is a further step in the study of organisational interventions to support cooperation between sick-listed employees and their supervisors in a generic population. We designed a field study of an overall high methodological quality and found no significant intervention effects. Yet, the results showed a tendency towards intervention effectiveness regarding the work resumption outcomes. The lack of significant effects was attributed to methodological limitations (e.g. limited power), coss-related limitations (e.g. questionnaire was not an adequate monitoring instrument) and COSS was only partially used.

RTW professionals can adjust COSS to make it a generic intervention that can best be applied in uncertain situations such as when contact between sick-listed employees and their supervisors does not come about spontaneously. Recommendations regarding the implementation of COSS are provided elsewhere [15].

Researchers should try to prevent some limitations of the present study in future research, for example by selecting a more neutral research setting, i.e. an organisation with less outstanding and more usual quality of common practice.

\section{List of abbreviations used}

COSS = Cooperation between Sick-listed employee and Supervisor

$\mathrm{HR}=$ Human Resource

$\mathrm{ICT}$ = Information- and Communication Technology

METC $=$ Medical Ethical Committee

$\mathrm{OHS}=$ Occupational Health Service

$\mathrm{OP}=$ Occupational Physician

RTW = Return -To-Work

\section{Acknowledgements}

The authors wish to thank the Dutch Foundation 'Stichting Instituut Gak-SIG' for providing funding for this study. We also thank the organisations where the research was carried out as well as the study participants. We thank Prof. dr. Hans Bosma and dr. Elisabeth Dorant for their advice on the survival analyses. 


\section{References}

1. Waddell G, Burton AK. Is work good for your health and well-being? London: TSO; 2006

2. Friesen MN, Yassi A, Cooper J. Return-to-work: the importance of human interactions and organisational structures. Work. 2001;17:11-22.

3. Lysaght RM, Larmour-Trode S. An exploration of social support as a factor in the return-to-work process. Work. 2008;30:255-66.

4. Wrapson W, Mewse AJ. Supervisors' responses to sickness certification for an episode of low back pain: employees' personal experiences. Disabil Rehabil. 2011;33:1728-36.

5. Scott WR: Institutions and organisations: Ideas and Interests (3rd ed.). Los Angeles: Sage Publications; 2008.

6. Overheid.nl. Wet Verbetering Poortwachter [Improved Gatekeeper Act]. http://wetten.overheid.nl/BWBR0013063/geldigheidsdatum_05-04-2012

7. Maiwald K, Meershoek A, de Rijk A, Nijhuis F. How policy on employee involvement in work reintegration can yield its opposite: employee experiences in a Canadian setting. Disabil Rehabil. 2013;35:527-37.

8. Maiwald K, Meershoek A, de Rijk A, Nijhuis F. Policy on manager involvement in work re-integration: Managers' experiences in a Canadian setting. WORK. 2013. doi: 10.3233/WOR-131727.

9. Karlson B, Jönsson P, Pålsson B, Åbjörnsson G, Malmberg B, Larsson B, Österberg K. Return to work after a workplace-oriented intervention for patients on sick-leave for burnout - a prospective controlled study. BMC Public Health. 2010;10:301.

10. Karlson B, Jönsson P, Österberg K. Long-term stability of return to work after a workplace-oriented intervention for patients on sick leave for burnout. BMC Public Health. 2014;14:281.

11. Hoefsmit N, Houkes I, Nijhuis FJN. Intervention characteristics that facilitate return to work after sickness absence: A systematic literature review. J Occup Rehab. 2012;22:462-77.

13. Hoefsmit N, Houkes I, Nijhuis FJN. Environmental and personal factors that support early return-to-work: A qualitative study using the ICF as a framework. WORK. 2014;48:203-15.

14. Hoefsmit N, de Rijk A, Houkes I. Work resumption at the price of distrust: a qualitative study on return to work legislation in the Netherlands. BMC Public Health. 2013;13:153.

15. Hoefsmit N, Boumans N, Houkes I, Nijhuis FJN. A process evaluation of a return-to-work intervention to improve cooperation between sick-listed employees and their supervisors (COSS). Submitted.

16. Noben C, Hoefsmit N, Evers S, de Rijk A, Houkes I, Nijhuis FJN. Economic evaluation of a new organizational RTW intervention for Cooperation between Sick-listed employees and their Supervisors (COSS): A field study. Submitted to Plos One.

17. Cohen J. Statistical power analysis for the behavioural sciences. 2nd ed. New Jersey: Lawrence Erlbaum Associates; 1988.

18. Oemar M, Janssen B. EQ-5D-5L User Guide. Basic information on how to use the EQ-5D-5L instrument. Rotterdam: EuroQol group; 2013.

19. Herdman M, Gudex C, Lloyd A, Janssen M, Kind P, Parkin D, Bonsel G, Badia X. Development and preliminary testing of the new five-level version of EQ-5D (EQ-5D-5 L). Qual Life Res. 2011;20:1727-36.

20. Euroqol. EQ-5D-5L Value Sets. http://www.euroqol.org/about-eq-5d/valuation-of-eq-5d/eq-5d-5I-valuesets.html

21. Polit DF, Beck CT. Essentials of Nursing Research: Appraising Evidence for Nursing Practice (8th edition). Philadelphia: Wolters Kluwer Health | Lippincott Williams \& Wilkins; 2014.

22. Statistics Netherlands. Ziekteverzuim op laagste punt sinds 1996 [Sickness absence at lowest level since 1996].http://www.cbs.nl/nl-NL/menu/themas/arbeidsocialezekerheid/publicaties/artikelen/archief/-

2014/2014-4047-wm.htm 


\section{CHAPTER 7}

Economic evaluation of a new organizational RTW intervention to improve cooperation between sick-listed employees and their supervisors (COSS):

a field study

Noben C, Hoefsmit N, Evers S, de Rijk A, Houkes I, Nijhuis FJN

Submitted 


\section{Abstract}

Objectives: This study aimed to evaluate the cost effectiveness, -utility, and -benefit of a new organizational return-to-work (RTW) intervention for Cooperation between Sicklisted employees and their Supervisors (COSS).

Methods: An economic evaluation was carried out alongside a field study with a 6month follow-up comparing COSS with common practice. Eligible participants aged 1860 , at sick leave for at least 2 weeks, and performing paid labor for at least 12 hours per week at the onset of absence were randomized to the coss- $(n=39)$ or common practice group $(n=25)$. The newly developed intervention aimed to improve cooperation between employee and supervisor regarding RTW possibilities. Outcomes were initial RTW, quality adjusted life years (QALY), and productivity gains. The economic evaluations were conducted from the societal and the organizational perspective.

Results: COSS was cost effective compared with common practice for initial RTW. The cost utility analysis showed reduced costs, however gain in QALYs were uncertain. From an organizational perspective, the net benefit of COSS compared to common practice yielded a productivity gain of €395.89 per invested euro.

Conclusions: COSS was cost effective and generated a positive financial return. Implementing COSS for sick-listed employees has large potentials to reduce societal and organizational costs and improve productivity and quality of life. Nonetheless, research with a longer time span is needed to detect whether COSS has the potential of reaching sustainable RTW in a cost effective manner. 


\section{Introduction}

Long-term sickness absence contributes largely to the total costs of work disability in Western countries. In the Netherlands, sickness absence among employees was up to 3.9 percent in 2013 [1]. Long term sickness absence adds to health- and economic problems as it is associated with a reduced probability of eventual return-to-work (RTW), followed by economic and social withdrawal. Reducing work disability to decrease absence and enhance RTW is an international government's top priority [2]. Cost effective RTW interventions are needed to achieve these aims. However, insight into the economic consequences of most existing RTW interventions is lacking. Although several studies performed cost effectiveness evaluations, most were among patients with specific diagnoses (i.e. distress, back pain, etc.) and are usually accessible to employees via healthcare providers or insurers [3-7]. These interventions can be regarded as a continuation of medical/clinical treatment (see, for example [8]).

The newly developed organizational intervention to enhance 'COoperation regarding return-to-work between Sick-listed employees and their Supervisors' (COSS) is innovative and generic as it is can be applied to all employees, regardless of their diagnoses or medical treatment. Supervisors will be interested in such interventions as they are not always allowed to ask employees about their health complaints [9]. COSS aims to resolve bottlenecks at the organizational level that were described in earlier research such as a lack of trust and open communication between the sick-listed employee and the supervisor [10-13]. COSS is complementary to Dutch legislation, which in itself appears to be insufficient to realise an adequate cooperation between sick-listed employees and their supervisors [13].

The objective of this study is to conduct an economic evaluation of cOSS by assessing the cost effectiveness, -utility, and -benefit of cOSS compared with common practice.

\section{Methods}

Study design

An economic evaluation was carried out alongside a field study comparing coss with common practice with a 6 months follow-up. The study was conducted in the Netherlands between 2012 and 2014 by researchers from Maastricht University (Dutch trial register: NTR3151). In line with the Dutch legislation this study did not require approval by an ethical committee (correspondence dd. 7 November 2011, registration number: METC 11-4-115). Most data were self-reported, except for sick-leave data which were retrieved from the participating organization's administration (a banking organization, which preferred to be anonymous). 
An economic evaluation was conducted from both the societal and organizational perspective. Cost effectiveness- (CEA), cost utility- (CUA), and cost benefit (CBA) analyses were performed. The costs included were categorized into intervention, healthcare, patient and family, and other sectors (i.e. productivity). To avoid double counting in the CEA when productivity served the outcome of interest, solely intervention-, health care-, and patient and family costs were accounted for. More details on the cost categories can be seen in Table 2. Appendix 1 presents an overview of the different perspectives and types of economic evaluations conducted in this study.

\section{Study population}

Eligible participants were aged 18-60, sick listed for at least 2 weeks and performed paid labor for at least 12 hours per week at the onset of absence. Participants were excluded when their actual sick leave at baseline overreached 10 weeks or were terminally ill.

\section{Interventions}

\section{Common practice}

Dutch legislation requires supervisors to compensate their employees at sick-leave for at least $70 \%$ of their income during two years [9,14-15]. The Improved Gatekeeper Act prescribes obligatory procedures for employees and supervisors during this period (e.g. compose an action plan for RTW, monitor its progress, etc.) [16]. According to the Act, occupational physicians should be contacted (and paid for) by supervisors to analyze the employees' functional limitations and to advise regarding RTW [9,15-16].

Additional to legislation, the banking organization has an own sick leave policy that prescribed weekly meetings between sick-listed employees and their supervisors.

\section{coss}

Additional to the legal requirements and the organizational policy, the cooperation between sick-listed employees and their supervisors was guided by the cOSS intervention. cOSS consisted of: (i) a conversation roadmap (step-by-step cooperation plan); (ii) a regular monitoring of the cooperation by using questionnaires at predetermined time points; and (iii) extra occupational physician support. The research team analyzed the questionnaire results (cut-off scores) and wrote an advice on the cooperation for the OP who provided extra support if needed. The intervention was provided continuously until full RTW.

More in depth details regarding COSS- and common practice can be found elsewhere [17]. 
The main outcomes were initial return-to-work (iRTW) and quality-adjusted life years (QALYS). IRTW was measured as duration in calendar days from the moment of employee inclusion onwards until initial return-to-work (iRTW) until maximally 6 months after inclusion. iRTW is conceptualized as the first moment at which progress is made in hours worked, even if the employee works less hours than contracted or if the employee is still (partly) sick listed [18]. Quality Adjusted Life Years (QALY) was assessed by using the self-administered EuroQol-5D-5L questionnaire. Health outcomes were measured on five dimensions: mobility, self-care, daily activities, pain and discomfort, and depression and anxiety [19]. Utilities were delineated by using the EQ-5D-5L crosswalk value set [20] to obtain Dutch tariffs and an overall utility score for population-based quality of life [21]. QALYs were calculated by multiplying the utility with the amount of time a patient spent in a particular health state. The maximum possible number of QALYs within the 6 months is 0.5 (half a year multiplied by 1 , the optimal health state).

\section{Resource use and valuation}

\section{Intervention costs}

Intervention costs were calculated based on a bottom-up micro-costing approach (appendix 2) and consisted of expenditures related to both developing and offering the intervention. For the economic evaluation, the costs of offering coss were relevant; i.e. monitoring cooperation based on the questionnaires and training and extra support by occupational physicians (appendix 2, part B). The reach (of potential participants) is based on the average number of sick-listed employees in the participating organization $(\mathrm{N}=2266)$.

\section{Healthcare costs}

Self-reported questionnaires with a recall period of 6 months were posted to the participant at baseline and 6 months after randomization to collect resource use frequencies. Discounting of costs was not necessary because the follow-up was one year. At every assessment, information was collected about the volume of health care consumption using a modified version of the Trimbos/iMTA questionnaire for costs (TicP) [22]. The modified questionnaire comprised medical aids through consults and admissions to the general practitioner, occupational physician, movement therapist, medical specialist, mental healthcare worker, alternative treatment, professional home care, hospitalization, rehabilitation clinic, and psychiatric institution. The respective units of resource use were multiplied by standard Dutch unit prices according to the Dutch guideline for costing research [23]. Costs were indexed to 2012 euro (€) by means of the consumer price indexes of Statistics Netherlands [24]. Tariffs or average 
prices were used when standard price weights were not available. The costs of prescription medicines were calculated by deriving the standard daily dosage as published by the Dutch Pharmacotherapeutic Compass [25] and multiplied by the price per dose [26] and the number of intake days. The pharmacist's dispensing costs (€5.99) and the general practitioners' prescription costs were added ( $€ 14)$ to the costs of prescription medicines [23]. Over the counter drugs (including 6\% taxes) were based on their market prices. Aids such as home interior elements, orthotics, mobility aids, etc. were based on the total costs per user for the reference year 2012 within the aid category as provided by the Dutch care institute [27].

\section{Patient and family costs}

Patient and family costs relate to informal care costs and parking and travel costs incurred while using health care resources. As the official unit price for informal care is not available, it was valued against the 'shadow price' of the wage rate per hour of a housekeeper [28]. Travelling and parking costs were calculated by multiplying average distance with the standard price weights according to the Dutch guideline for costing research or on average distance as presented in Warmerdam et al. 2010 [29].

\section{Costs in other sectors (productivity costs)}

The 'friction costs approach' (FCA) was used to value productivity costs. FCA states there is a short-run friction period during which the organization might incur losses as an adjustment is made to a employees' absence. However, in the long run, no (more) losses are held to occur because the employee either returned to work and the productivity returned, or the organization replaced the injured employee and productivity became comparable to what it was before $[28,30]$. The friction cost approach thus assumes productivity losses only occur during the 'friction period'; the time needed to replace and train new employees. The friction period for the Netherlands was estimated based on the availability of labor-that is, the level of unemployment [30]. The friction period for 2012 in the Netherlands contained 13.24 weeks (92.68 days). Productivity cost estimates were based on self-reported average daily wage rates multiplied with the number of days until initial work resumption (sickleave data retrieved from the banking organization) and with 0.8 to adjust for the elasticity between working time and productivity, which represents reduced labor efficiency, as prescribed by the costing manual [23]. Productivity costs were only calculated when lost work was not compensated (i.e. through extra working hours, by colleagues or by temporary or permanent replacement) as it was assumed that absenteeism compensated for did not result in lost productivity. Detailed information on the calculation used to estimate the friction period and the productivity costs can be derived via the first author. 
Data were analyzed according to the intention-to-treat principle. All participants were analyzed in the condition to which they were randomized after inclusion based on their baseline questionnaire responses. Missing values at baseline were imputed via mean imputation techniques. Missing data at follow-up were imputed by using the last observation carried forward, assuming no changes in effect or cost over time. All analyses were conducted in IBM SPSS Statistics 21 and Microsoft Excel.

\section{Economic evaluation}

For the cost effectiveness analyses (CEA), incremental cost effectiveness ratios (ICERs) were determined to indicate the additional investments needed for COSS to gain one extra unit of effect compared with common practice. The following calculation was used; (C1-C0)/(E1-E0), where $C$ is the average cost and $E$ is the proportion of respondents achieving initial RTW. The total costs were calculated by the sum of the intervention-, healthcare-, and patient and family costs. In order to calculate the incremental cost utility ratio (ICUR) the incremental costs (intervention-, healthcare-, patient and family-, and productivity costs) are divided by the difference in QALYs. The cost benefit analysis (CBA) calculated the net monetary benefit (NB) and the benefitcost ratio (BCR) from the organizational perspective. The NB was derived by subtracting the mean difference in intervention costs between both groups from the difference in productivity costs. The BCR was calculated by dividing the benefits of the investment by the costs of the investment in order to calculate the amount of money returned per euro invested. Financial returns were positive if $\mathrm{NB}>0$ and $\mathrm{BCR}>1$.

Non-parametric bootstrap re-sampling techniques were used to capture the uncertainty surrounding the incremental costs. Using the original data, 5000 replications of the cost-effect pairs were generated and plotted on one of the four quadrants of the cost effectiveness plane to display differences in costs on the vertical axis and differences in effects on the horizontal axis. In the North-east quadrant the intervention produces superior effects at additional costs relative to common practice. In the North-west quadrant less effect is produced for additional costs meaning the intervention is "dominated" by the common practice condition. In the South-west quadrant less effect is produced, but there are some cost-savings. And finally, in the South-east quadrant the intervention generates superior effects for less costs; the intervention "dominates" common practice.

The bootstrapped ratios were furthermore used to construct an acceptability curve which indicates the probability of the intervention being cost effective at a predetermined ceiling ratio $(€)$; which is society's willingness to pay (WTP) to gain one extra unit of effect (e.g. one QALY). The WTP depends on the type of disease and its severity; which is higher for very severe conditions (i.e. a tentative maximum of $€ 80,000)$ than for mild conditions in the Netherlands [32]. For the coss intervention it 
was difficult to choose one threshold based on the severity of conditions, as participants in the field study have a variety of diseases. The acceptability curve however demonstrates the probability of COSS being cost-effective at a ceiling ratio of $€ 18,000$, indicating that coss has the likelihood of being cost effective for the whole spectrum of diseases from non-severe till severe conditions (see Figure 2, part B).

To ascertain the robustness of the findings, different sensitivity analyses were carried out. As elder employees might stay on longer sick leave or use the claim of work disability absenteeism as an alternative to retirement, especially among those over 55 years of age was used [33], the first sensitivity analysis therefore tested whether faster work resumption due to COSS can be achieved among employees between 40 and 60 years of age when compared to common practice. Secondly, because coss is developed to be broadly implementable because of its non-disease specific focus, a subgroup analysis controlling for chronic disability is conducted. Thirdly, a cost utility analysis was calculated by using similar costs as the cost effectiveness analysis. Finally, a cost benefit sensitivity analysis was performed in which the intervention costs were higher as they were based on the actual uptakes $(n=39)$.

\section{Results}

\section{Participants}

90 participants from six departments at the banking organization were randomized to the COSS- and common practice group and filled in the baseline questionnaire. Complying with the inclusion criteria, the data of 39 participants in the COSS group and 25 in the common practice group were analyzed at baseline and after 6 months followup. Figure 1 provides more details on the participants' flow throughout the study.

Table 1 lists the baseline characteristics of both groups. Significant differences across both groups were found for age, gender and the average number of working hours. None of the cost categories were significantly different when comparing both groups, though on average, costs were higher in the common practice group. 


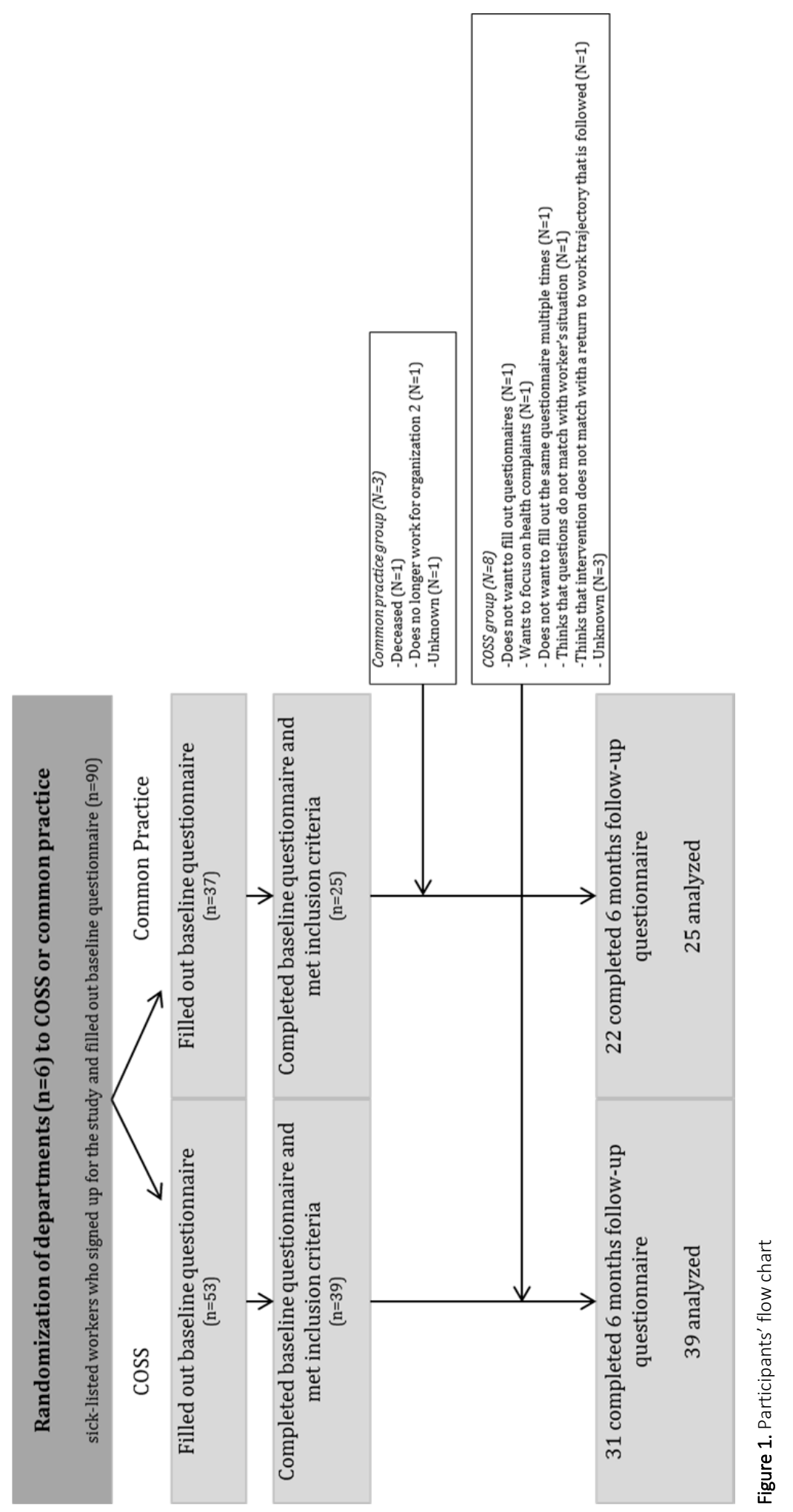


Table 1. Baseline characteristics $(\mathrm{N}=64)$

\begin{tabular}{|c|c|c|c|}
\hline & $\begin{array}{l}\text { Coss } \\
\text { Group }(n=39)\end{array}$ & $\begin{array}{l}\text { Common Practice } \\
\text { Group }(n=25)\end{array}$ & $p$-value \\
\hline Age, mean (sd) & $45.31(9.2)$ & $50.6(7.4)$ & $0.019(\mathrm{a}) *$ \\
\hline Female, N (\%) & $25(64)$ & $7(28)$ & $0.005(\mathrm{~b})^{* *}$ \\
\hline \multicolumn{4}{|l|}{ Education, $\mathrm{N}(\%)^{\dagger}$} \\
\hline Low & $7(18)$ & $6(24)$ & $0.06(b)$ \\
\hline Intermediate & $19(49)$ & $4(16)$ & \\
\hline High & $12(31)$ & $14(56)$ & \\
\hline Other & $1(2)$ & $1(4)$ & \\
\hline Working hours, mean (sd) & $31.72(6.8)$ & $35.20(4.6)$ & $0.018(a) *$ \\
\hline \multicolumn{4}{|l|}{ Marital Status, N (\%) } \\
\hline Married & $24(62)$ & $21(84)$ & $0.15(b)$ \\
\hline Living together with a partner & $9(23)$ & $3(12)$ & \\
\hline Divorced & $5(13)$ & 0 & \\
\hline Single & $1(2)$ & $1(4)$ & \\
\hline Children under 12 years, N (\%) & $18(46)$ & $6(24)$ & $0.07(b)$ \\
\hline Permanent employment, N (\%) & $39(100)$ & $24(96)$ & $0.21(b)$ \\
\hline Managerial position, N (\%) & $3(7.7)$ & $4(16)$ & $0.3(b)$ \\
\hline Shift work, N (\%) & $2(5.1)$ & $1(4)$ & $0.84(b)$ \\
\hline \multicolumn{4}{|l|}{ General Health, N (\%) } \\
\hline Excellent & $1(3)$ & $1(4)$ & $0.97(b)$ \\
\hline Very Good & $10(26)$ & $7(28)$ & \\
\hline Good & $22(56)$ & $14(56)$ & \\
\hline Moderate & $6(15)$ & $3(12)$ & \\
\hline \multicolumn{4}{|l|}{ Long term disability, N (\%) } \\
\hline None & $30(77)$ & $16(64)$ & $0.26(b)$ \\
\hline One or more & $9(23)$ & $9(36)$ & \\
\hline EQ-5D-5L Utilities, mean (sd) $\bar{\top}$ & $0.65(0.16)$ & $0.63(0.24)$ & $0.8(a)$ \\
\hline \multicolumn{4}{|l|}{ Costs, mean in $€(\mathrm{sd})$} \\
\hline Healthcare costs & $1,348.56(1609.7)$ & $1,813.64(2099.89)$ & 0.72 (c) \\
\hline Medication \& aids & $110.1(206.17)$ & $125.6(184.48)$ & 0.24 (c) \\
\hline Health care service use & $1,238.46(1454.03)$ & $1,688.04(2017.45)$ & 0.7 (c) \\
\hline Patient and family costs & $208.03(376.06)$ & $254(462.18)$ & 0.91 (c) \\
\hline Informal care costs & $137.12(364.54)$ & $190.03(457.03)$ & 0.85 (c) \\
\hline Travel and parking costs & $70.9(60.48)$ & $63.77(40.32)$ & $0.92(c)$ \\
\hline
\end{tabular}

+Low=preschool, primary school; intermediate= lower and upper secondary; high=tertiary school, university, or postgraduate.

THigh scores indicate better perceived health outcomes

(a) Anova (b) Pearson Chi-squared test (c) Non-parametric Kruskal Wallis test

* Significant at the $5 \%$ level ** Significant at the $1 \%$ level 
After six months follow-up, no significant cost differences were found (Table 2). Despite for intervention costs, the average costs per category were highest in the common practice group. Occupational physician-, mental healthcare worker-, alternative treatment-, hospitalization-, and prescribed medication costs were higher in the coss group. Incremental costs based on the bootstrapped subtotals indicated costs were lower in the coss group when compared to the common practice group.

Table 2. Total costs per cost item and subtotal bootstrapped costs after 6 months follow-up

\begin{tabular}{|c|c|c|c|}
\hline Cost category & $\begin{array}{l}\text { Coss Group, } \\
\text { costs } €(n=39)\end{array}$ & $\begin{array}{l}\text { Common Practice Group, } \\
\text { costs } €(n=25)\end{array}$ & $\begin{array}{l}\text { Incremental costs, } € \\
(2,5-97,5 \text { percentile })\end{array}$ \\
\hline Intervention costs & 2.19 & 0 & n.a. \\
\hline \multicolumn{4}{|l|}{ Healthcare costs } \\
\hline General practitioner & 90.71 & 98.7 & \\
\hline Occupational physician & 140.9 & 112.88 & \\
\hline Movement therapist & 236.35 & 367.39 & \\
\hline Medical specialist & 100.35 & 187.32 & \\
\hline Mental healthcare worker & 243.05 & 58.9 & \\
\hline Alternative treatment & 45.89 & 13.42 & \\
\hline Professional home care & 8.85 & 8.28 & \\
\hline Rehabilitation clinic & 0 & 0 & \\
\hline Psychiatric institution & 0 & 0 & \\
\hline Hospitalization (day parts) & 314.38 & 191.91 & \\
\hline Hospitalization (admissions) & 783.76 & 1308.47 & \\
\hline Prescription medication & 77.21 & 50.6 & \\
\hline Over-the-counter medication & 4.79 & 10.64 & \\
\hline Aids & 3.22 & 40.88 & \\
\hline Subtotal & 2049.47 & 2449.39 & \\
\hline Bootstrapped subtotal, & $1,105.57$ & $1,710.51$ & -605 \\
\hline mean $(\mathrm{sd})$ & $(140.76)$ & $(330.81)$ & $(-1343$ to 38$)$ \\
\hline \multicolumn{4}{|l|}{ Patient and family costs } \\
\hline Informal care & 106.5 & 114.12 & \\
\hline Parking and travel costs & 94.34 & 110.75 & \\
\hline Subtotal & 200.84 & 224.88 & \\
\hline Bootstrapped subtotal, & 201.49 & 226.34 & -25 \\
\hline mean $(\mathrm{sd})$ & $(50)$ & $(59.24)$ & $(-175$ to 129$)$ \\
\hline Cost category & $\begin{array}{l}\text { COSS Group, costs } € \\
(n=39)\end{array}$ & $\begin{array}{l}\text { Common Practice Group, } \\
\text { costs } €(n=25)\end{array}$ & $\begin{array}{l}\text { Incremental costs, } € \\
(2,5-97,5 \text { percentile })\end{array}$ \\
\hline \multicolumn{4}{|l|}{ Costs in other sectors } \\
\hline Productivity costs & $1,004.64$ & $1,918.89$ & \\
\hline Bootstrapped subtotal, & $1,078.03$ & $1,944.80$ & -867 \\
\hline mean $(s d)$ & $(288.77)$ & $(497.05)$ & $(-1991$ to 187$)$ \\
\hline
\end{tabular}




\section{Cost effectiveness analyses}

The CEA (see Table 3) showed an ICER of 26.78 ( $\triangle \mathrm{C}=-421.77 / \Delta \mathrm{E}=-15.75$ ) meaning COSS was less costly and more effective (i.e. almost 16 reduced calendar days of absenteeism) compared to common practice and $€ 26.78$ is saved per day of work resumption. See also Figure 2 (part A) where $68 \%$ of the bootstrapped ICERs are located in the south east quadrant (indicating more effect and less costs). The cost effectiveness acceptability curve (CEAC) indicates that at a willingness to pay of $€ 100$ for one day earlier work resumption, the probability of COSS being cost effective is $87 \%$.

(A)
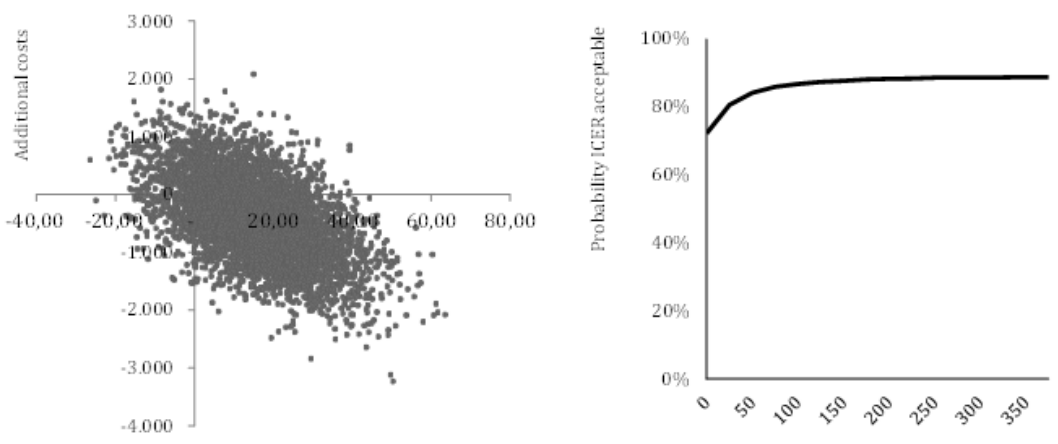

Willingness to pay

(B)

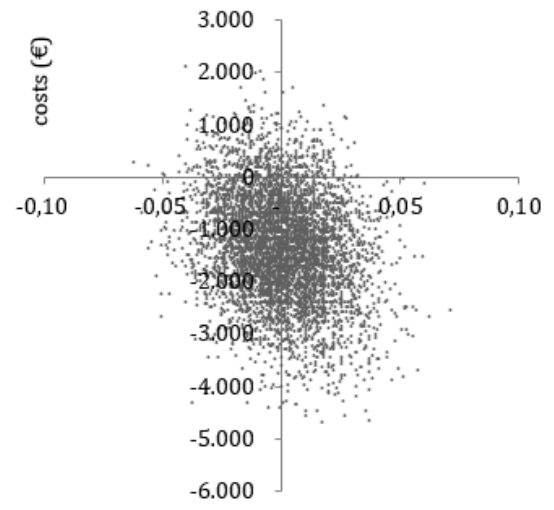

QALY

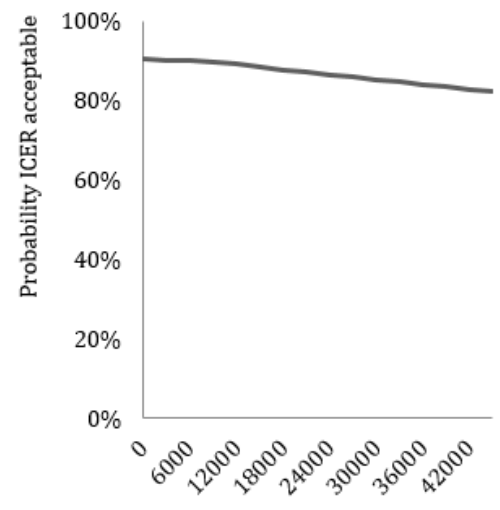

Willingness to pay

Figure 2. Cost effectiveness plane and cost effectiveness acceptability curve for differences in (A) initial RTW, (B) QALYS 


\section{Cost utility analysis}

The bootstrapped results in Figure 2 (part B) show that $44 \%$ and $47 \%$ of the cost effectiveness pairs are located in respectively the southwest and southeast quadrant where COSS is less costly but the difference in effect is uncertain (wide spread of the point estimates (see also Table 3)). Based on the acceptability curve, coss has a probability of approximately $88 \%$ of being cost effective at the considered ceiling ratio of $€ 18,000$ for this study. The acceptability curve descends, meaning that the probability of COSS being cost effective decreases when the value society attaches to a QALY increases.

\section{Cost benefit analysis}

The costs of the intervention were $€ 2.19$ higher than in common practice. Productivity costs according to the friction cost method were $€ 867$ lower in the cOSS group compared to the common practice group (see table 2). The net benefit for the supervisor is €864.81 and the BCR is €395.89; indicating a productivity gain for the supervisor of almost €396 per invested euro.

\section{Sensitivity analysis}

With respect to the first sensitivity analysis, results were robust when using the data of employees aged between 40 and 60 years. Almost $€ 41$ was saved per work resumption day. Results of the main analysis were also similar to the sensitivity analysis whereby only employees without a chronic disability were included in the analysis. One day earlier work resumption among employees without a chronic disability resulted in a cost saving of almost $€ 50$. The subgroup of employees with a chronic disability yielded faster return to work, however, contrasting the main analysis; an additional investment of almost $€ 18$ was needed. A summary of the findings is shown in table 3 . With respect to costs per QALY, the results of the fourth sensitivity analysis were robust when omitting productivity costs. The acceptability curve descended from $74 \%$ (best case with 3000 euro willingness to pay to gain one QALY) to 65\% (worst case). Assessing the robustness of the findings from the organizational perspective by accounting the costs of the intervention depending on the actual uptake rates $(\mathrm{N}=39)$ were comparable to the results of the main analysis. The intervention costs increased from 2.19 euro to 127.35 euro. The net benefit for the supervisor is $€ 739.65$ and the BCR productivity was $€ 6.89$ per invested euro, indicating that COSS still produced a positive financial return. 


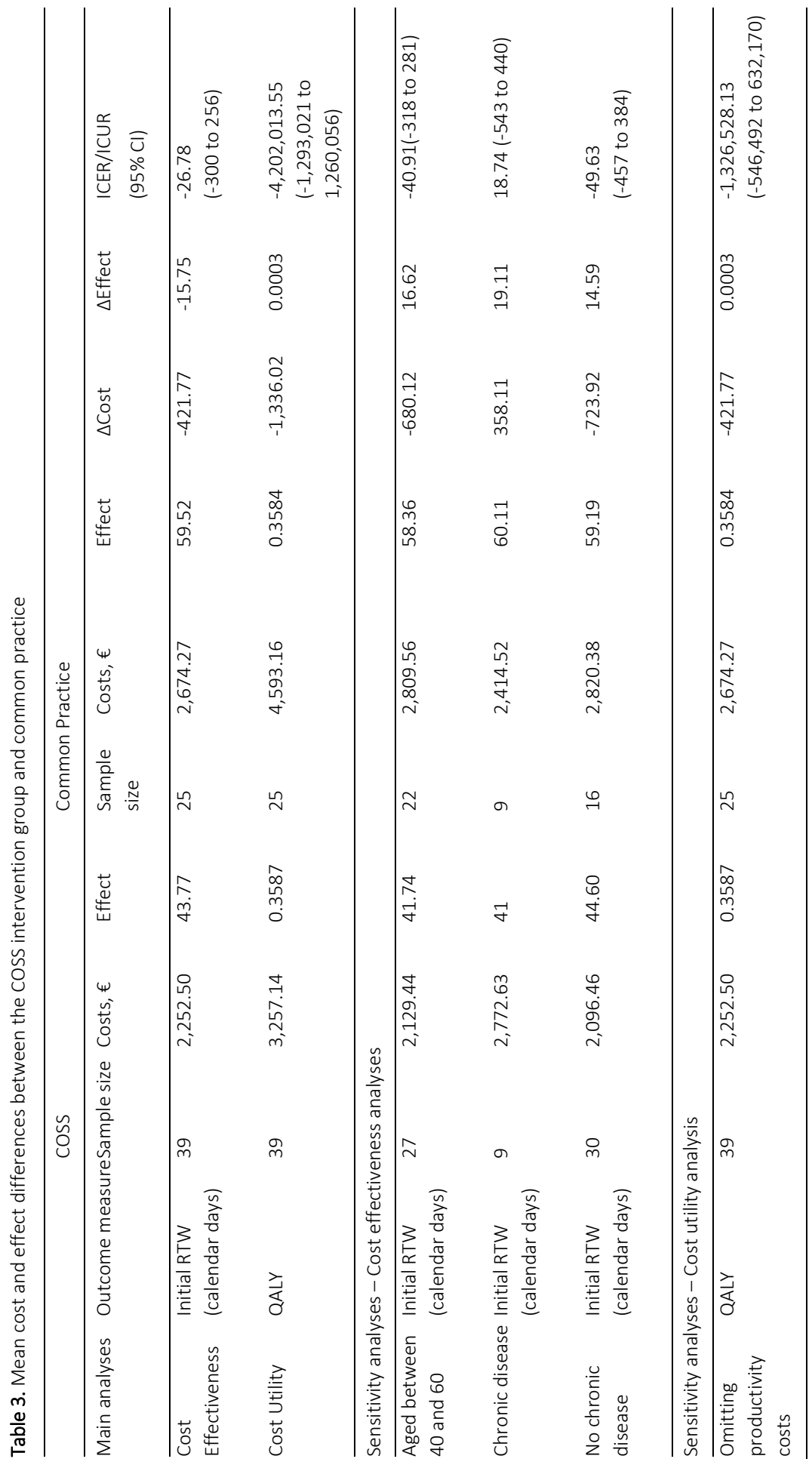




\section{Conclusions}

A new organizational RTW intervention for Cooperation between Sick-listed employees and their Supervisors (COSS) appeared to have substantial economic benefits over common practice. The cost effectiveness acceptability curve indicated that the probability of COSS being cost effective compared with common practice was $87 \%$ for ceiling ratios larger than $€ 100$ to gain one day of earlier initial return to work. For QALYS gained, the cost effectiveness acceptability curve indicated that coss had a cost effectiveness probability of almost $88 \%$ at a ceiling ratio of $€ 18,000$.

This study combined different types of economic evaluations (i.e. cost effectiveness, -utility, and -benefit) from diverse perspectives to compare the organizational intervention, regardless of the employees' diagnoses, with common practice. Lower costs and higher effects of COSS when compared to common practice resulted in an ICER of almost $€ 27$ per initial return-to-work calendar day. Exploring the robustness of the results in several sensitivity analyses resulted in comparable findings. coss remained cost effective, even among the group of older employees (age range between 40 and 60 years) that generally have longer sickness absence spells [33]. Employees either with or without a chronic illness receiving COSS returned to work faster when compared to common practice. Results in terms of QALYs were uncertain because the majority of the incremental cost utility ratios were located in the quadrant of 'fewer costs, more effects' and 'fewer costs, less effects'. Exploring the incremental cost-utility omitting productivity costs resulted in comparable findings. From an organizational perspective, coss can be regarded as cost saving to the employer, even when upgrading the intervention costs. A recent review yielded similar overall positive results on the financial return of worksite health promotion programs [34].

\section{Strengths and limitations}

The main strengths of this study were its pragmatic ('real life setting') design, the different perspectives (i.e. societal, organizational, healthcare) used to assess different types of economic evaluations (CEA, CUA, and CBA), the use of objective sick-leave data, and the transparent registration of the intervention costs, limiting the risk of over- or underestimation actual costs. Another strength is the inclusion of productivity loss caused by reduced labor efficiency by accounting for elasticity when using the net cumulative days of sick leave as the proxy for productivity loss. Accounting for presenteeism reduced the risk of over- or underestimating actual productivity costs in both groups alike. The effectiveness study confirmed the findings of this study when investigating the time to first RTW (i.e. a tendency towards effectiveness in the cOSS 
group). Also, when addressing full- and sustainable RTW in calendar days, a tendency towards effectiveness was found in favor of the COSS group [35]. Further research is needed to detect whether COSS has the potential of reaching sustainable RTW at lower costs when compared to common practice. To economically evaluate the potential positive effects of COSS on full- and sustainable RTW over an adequate follow-up period and a longer time span more research is needed as it took more time than anticipated to recruit individual employees and supervisors. Furthermore, the generalizability of the study results is not boundless. The Netherlands holds a unique position regarding RTW policy [15], and COSS was specifically tailored to and implemented in the Dutch context. Taking into consideration that the common practice is already more intensive due to legal requirements for cooperation [15] when compared to other countries (e.g. Belgium, Canada or the US), the effects of the intervention might be higher in countries where no legal requirements for cooperation and collaboration are set.

\section{Concluding remarks}

In the Netherlands, there is a strong need for research regarding cost-effectiveness studies of interventions on working conditions, social work environment and health [36]. This study demonstrated the cost effectiveness of coss. For the cost utility, the high utility scores at baseline might explain the uncertainty regarding the effectiveness for both COSS and common practice, making it difficult to detect an increase over time. cOSS yielded a cost saving and from an organizational perspective even a positive financial return regarding first RTW.

\section{Acknowledgement}

We want to thank the banking organization and the study participants for their collaboration and participation. We also thank medical doctor Kees de Cock for his assistance while estimating the per person average number of days of medication usage based on time spans of usage, type and combinations. 


\section{References}

1. Statistics Netherlands. Ziekteverzuim op laagste punt sinds 1996 [Sickness absence at lowest level since 1996]. 2014. http://www.cbs.nl/nl-NL/menu/themas/arbeidsocialezekerheid/publicaties/artikelen/archief/2014/2014-4047-wm.htm. Accessed 2014.

2. Organisation for Economic Co-operation and Development. Sickness, Disability and Work: breaking the barriers. 2010. http://ec.europa.eu/health/mental_health/eu_compass/reports_studies/disability_synthesis_2010_en.pdf. Accessed 2014.

3. van Oostrom SH, Heymans MW, de Vet HC, van Tulder MW, van Mechelen W, Anema JR. Economic evaluation of a workplace intervention for sick-listed employees with distress. Occup Environ Med. 2010;67:603-10.

4. Loisel P, Lemaire J, Poitras S, Durand MJ, Champagne F, Stock S, Diallo B, Tremblay C. Cost-benefit and cost-effectiveness analysis of a disability prevention model for back pain management: a six year follow up study. Occup Environ Med. 2002;59:807-15.

5. Vermeulen SJ, Heymans MW, Anema JR, Schellart AJ, van Mechelen W, van der Beek AJ. Economic evaluation of a participatory return-to-work intervention for temporary agency and unemployed workers sick-listed due to musculoskeletal disorders. Scand J Work Environ Health. 2013;39:46-56.

6. Rebergen DS, Bruinvels DJ, van Tulder MW, van der Beek AJ, van Mechelen W. Cost-effectiveness of guideline-based care for workers with mental health problems. J Occup Environ Med. 2009;51:313-22.

7. Noben C, Smit F, Nieuwenhuijsen K, Ketelaar S, Gartner F, Boon B, Sluiter J, Evers S. Comparative costeffectiveness of two interventions to promote work functioning by targeting mental health complaints among nurses: pragmatic cluster randomised trial. Int J Nurs Stud. 2014;51(10):1321-31.

8. Tamminga SJ, Verbeek JH, Bos MM, Fons G, Kitzen JJ, Plaisier PW, Frings-Dresen MH, de Boer AG. Effectiveness of a hospital-based work support intervention for female cancer patients - a multi-centre randomised controlled trial. PloS one. 2013;8:e63271.

9. Overheid.nl. Wet Verbetering Poortwachter [Improved Gatekeeper Act]. [date unknown]. http://wetten.overheid.nl/BWBR0013063/geldigheidsdatum_10-04-2014.

10. Friesen MN, Yassi A, Cooper J. Return-to-work: The importance of human interactions and organizational structures. Work 2001;17:11-22.

11. Wrapson W, Mewse AJ. Supervisors' responses to sickness certification for an episode of low back pain: employees' personal experiences. Disabil Rehabil. 2011;33:1728-36.

12. Kremer AM, Steenbeek R. Avoidable sickness absence in a Dutch working population. J Occup Rehabil. 2010;20:81-9.

13. Hoefsmit N, de Rijk A, Houkes I. Work resumption at the price of distrust: a qualitative study on return to work legislation in the Netherlands. BMC Public Health. 2013;13:153.

14. Hop AD, de Pijper B, Sens IM, Wildenburg A, Baars MJH, Dekker EM, et al. De kleine gids voor de Nederlandse sociale zekerheid 2010 [Small guide for Dutch social security 2010]. Hop AD, editor. Hoofddorp: Kluwer; 2010.

15. Elders L, Burdorf A. Occupational medicine in The Netherlands. Occup Med (Lond). 2010;60:314.

16. Evers HGJ. De Wet Verbetering Poortwachter. Handleiding voor de praktijk [The Improved Gatekeeper Act. A practice guideline]. Deventer: Kluwer Juridisch; 2007.

17. Hoefsmit N, Boumans N, Houkes I, Nijhuis F.J.N. A process evaluation of a return-to-work intervention to improve Cooperation between Sick-listed employees and their Supervisors (COSS). Submitted.

18. de Rijk A, Janssen N, Alexanderson K, Nijhuis F. Gender differences in return to work patterns among sickness absentees and their associations with health: a prospective cohort study in The Netherlands. Int J Rehabil Res. 2008;31:327-36.

19. Herdman M, Gudex C, Lloyd A, Janssen M, Kind P, Parkin D, Bonsel G, Badia X. Development and preliminary testing of the new five-level version of EQ-5D (EQ-5D-5L). Qual Life Res. 2011;20(10):1727-36.

20. EuroQol. EQ-5D-5L Value Sets. [date unknown]. http://www.euroqol.org/about-eq-5d/valuation-of-eq5d/eq-5d-5l-value-sets.html. Accessed 2014. 
21. Lamers LM, Stalmeier PF, McDonnell J, Krabbe PF, van Busschbach JJ. Kwaliteit van leven meten in economische evaluaties: het Nederlands EQ-5D tarief [Measuring the quality of life in economic evaluations: the Dutch EQ-5D tariff]. Ned Tijdschr Geneeskd. 2005;149:1574-8.

22. Hakkaart-van Roijen L, van Straten A, Donker M, Tiemens B. Handleiding Trimbos/iMTA questionnaire for Costs associated with Psychiatric illness (TiC-P) [Manual Trimbos/iMTA questionnaire for Costs associated with Psychiatric illness (TiC-P)]. Rotterdam: Instituut voor Medische Technology Assessment, Erasmus MC; 2002.

23. Hakkaart L, Tan SS, Bouwmans CAM. Handleiding voor kostenonderzoek. Methoden en standaard kostprijzen voor economische evaluaties in de gezondheidszorg [Manual research into costs. Methods and standard cost prices for economic evaluations in healthcare]. Rotterdam: Instituut voor Medische Technology Assessment, Erasmus Universiteit Rotterdam, CVZ College voor zorgverzekeringen; 2010.

24. Statistics Netherlands. Consumer prices. 2014. http://statline.cbs.nl/StatWeb/publication/?DM=SLEN\&PA=80087ENG\&D1=0-1,4-5\&D2=0\&D3=(I-39)-I\&LA=EN\&VW=T. Accessed 2014.

25. Healthcare institute Netherlands. Farmacotheurapeutisch kompas [Pharmacotherapeutic compass]. September 2012. http://www.fk.cvz.nl/.

26. Healthcare Institute Netherlands. Medicijnkosten [drug costs in the Netherlands]. [date unknown] http://www.medicijnkosten.nl/. Accessed 2014

27. Healthcare institute Netherlands. GIP databank [GIP database]. [date unknown]. www.gipdatabank.nl. Accessed 2014.

28. Oostenbrink JB, Koopmanschap MA, Rutten FF. Standardisation of costs: the Dutch Manual for Costing in economic evaluations. Pharmacoeconomics. 2002;20:443-54.

29. Warmerdam L, Smit F, van Straten A, Riper H, Cuijpers P. Cost-utility and cost-effectiveness of internetbased treatment for adults with depressive symptoms: randomized trial. J Med Internet Res. 2010;12:e53.

30. Koopmanschap MA, van Ineveld BM. Towards a new approach for estimating indirect costs of disease. Soc Sci Med. 1992;34:1005-10.

31. Statistics Netherlands. Vacatures (openstaande, nieuwe en vervulde); overheid en onderwijs [Jobs (open, new and filled) government and education]. http://statline.cbs.nl/StatWeb/publication/?VW=T\&DM=SLNL\&PA $=80857 N E D \& L A=N L$. Accessed 2014.

32. Council for Public Health and Health Care. Sensible and sustainable care (in Dutch). Zoetermeer: Council for Public Health and Health Care; 2006.

33. Hesseling JH, Houtman I, van den Bossche S. Trends in ziekteverzuim [Trends in sickness absence]. The Hague: Sociaal Cultureel Planbureau; 2012.

34. van Dongen JM, Proper KI, van Wier MF, van der Beek AJ, Bongers PM, van Mechelen W, van Tulder MW. Systematic review on the financial return of worksite health promotion programmes aimed at improving nutrition and/or increasing physical activity. Obes Rev. 2011;12:1031-49.

35. Hoefsmit N, Houkes I, Boumans N, Noben C, Winkens B, Nijhuis FJN. The effectiveness of an intervention to enhance cooperation between sick-listed employees and their supervisors (COSS). Submitted.

36. Burdorf A. Research in occupational medicine in The Netherlands: responsiveness to societal needs. Occup Med (Lond). 2010;60:242-4. 


\section{Supplemental files for online publication}

Appendix 1. Main analyses for economic evaluation

\begin{tabular}{lll}
\hline Method & Costs $(€)$ & Outcome \\
\hline Cost Effectiveness & - healthcare costs & Initial RTW \\
& - patient and family costs & \\
& - intervention costs & \\
\hline Cost Utility & - healthcare costs & Quality Adjusted Life Years \\
& - patient and family costs & \\
& - intervention costs & \\
& - costs in other sectors & \\
& (productivity) & Monetary benefits \\
\hline Cost Benefit & - intervention costs & (productivity gain) \\
\hline
\end{tabular}


Appendix 2. Total per participant intervention costs

\begin{tabular}{|c|c|c|}
\hline Type of costs & Calculation & $\begin{array}{l}\text { Outcome } \\
(€)\end{array}$ \\
\hline \multicolumn{3}{|l|}{ Part A: Development costs } \\
\hline $\begin{array}{l}\text { Development of the } \\
\text { conversation roadmap }\end{array}$ & $\begin{array}{l}\text { Average wage rates per contributor multiplied with } \\
\text { average number of hours worked on the developments }\end{array}$ & $2,112.54$ \\
\hline $\begin{array}{l}\text { Development of questionnaires } \\
\text { and online versions. } \\
\text { Development of cut-off scores. }\end{array}$ & $\begin{array}{l}\text { Average wage rates per contributor multiplied with } \\
\text { average number of hours worked on the developments }\end{array}$ & $2,447.64$ \\
\hline $\begin{array}{l}\text { Sending out questionnaires and } \\
\text { reminders, reminder phone calls } \\
\text { and questionnaire analyses for } \\
\text { occupational physicians and } \\
\text { coaches }\end{array}$ & $\begin{array}{l}\text { Average wage rates per contributor multiplied with } \\
\text { average number of hours worked }\end{array}$ & $5,932.50$ \\
\hline $\begin{array}{l}\text { Improving COSS based on } \\
\text { feedback }\end{array}$ & $\begin{array}{l}\text { Average wage rates per contributor multiplied with } \\
\text { average number of hours worked }\end{array}$ & 158.20 \\
\hline Total costs: & & $5,311.88$ \\
\hline
\end{tabular}

Part B: Costs of offering the intervention

\begin{tabular}{llc}
\hline $\begin{array}{l}\text { Printing costs of the } \\
\text { conversation roadmap }\end{array}$ & Number of prints multiplied with the amount per print & 561.60 \\
$\begin{array}{ll}\text { Use of roadmap by supervisors } \\
\end{array}$ & $\begin{array}{l}\text { Hours required for reading and using the complete } \\
\text { roadmap multiplied with average sick leave duration in } \\
\text { months multiplied with average wage p. hour supervisor }\end{array}$ & 252.11 \\
&
\end{tabular}

Monitoring cooperation: Filling Average time per questionnaire multiplied with average out questionnaires by wage supervisor

supervisors

Preparing and providing an accredited training session to occupational physicians/coach

Average wage rates per contributor multiplied with average number of hours worked

Occupational physicians and coaches providing extra support to employees and/or supervisors

Average wage rates per contributor multiplied with average number of hours worked

\begin{tabular}{lc}
\hline Total costs: & $4,966.99$ \\
\hline Costs per participant* & 2.19 \\
\hline
\end{tabular}

* 2266 participants: representation of employees in the banking organization, accounting for the percentage of absence during the reference year 2012 
CHAPTER 8

General Discussion 

The first aim of this thesis was to provide an overview of the facilitators of- and bottlenecks for sick-listed employees and their supervisors' self-direction in return-towork (RTW) in multiple target populations and across interventions. To achieve this aim, we performed a systematic literature review of intervention characteristics that facilitate early RTW (study 1) and two qualitative interview studies. The first interview study was about environmental and personal factors that support RTW (study 2). The other focused at the cooperation between sick-listed employees and their employers (study 3).

A second aim of this thesis was to develop and evaluate a generic and organizational intervention to support the employees' and supervisors' self-direction in RTW. Our intervention aims to enhance COoperation between Sick-listed employees and their Supervisors (COSS), and was developed on the basis of the findings of the first three studies. COSS consists of a conversation roadmap for sick-listed employees and their supervisors, a regular monitoring of the quality of their cooperation and, if needed, extra support by an occupational physician (OP) (see Appendix 1). coss was introduced in a large banking organization. Afterwards, the process- (study 4), effectiveness- (study 5), as well as cost effectiveness -utility, and -benefit of coss (study 6) were studied. See also chapter 1 for a detailed description of the outline of this research.

This chapter summarises the main study findings for both aims of this thesis and provides some reflection on the study findings and methods used. Finally, implications for future research and practice are described.

\section{Main findings}

The results of studies 1-3 describe several facilitators of- and bottlenecks for selfdirection in RTW (first thesis aim). The results of the systematic literature review (study 1) indicated that for example early- and activating (e.g. implementing workplace modifications) intervention facilitates RTW in multiple target populations and interventions.

Next, a qualitative interview study (study 2) was performed, based on data collected from employees, HR professionals and OPs. The results described environmental factors that play a role in RTW. An example is the cooperation between several stakeholders in medical recovery- and RTW including employees, employers and curative care professionals. The results also described a personal factor that supports RTW, which is the employees' positive perception of the situation (e.g. enjoyment of their work).

Another qualitative study (study 3), based on interviews with employees and HR professionals, brought in-depth understanding of the cooperation between sick-listed employees and their employers. This study showed that legislation can ensure a 
minimum cooperation. However, other factors are also needed for adequate cooperation: trust, knowledge about the legislation and awareness of a mutual dependence to achieve one's primary goals (employees: medical recovery / employers: RTW). Norms about medical recovery and RTW also play a role in the employees' and employers' primary goals.

Studies 4-6 describe the development (based on insights derived from studies 1-3) and evaluation of cosS (second thesis aim). We evaluated the adoption and implementation of the intervention at the banking organisation in a process evaluation (study 4). This study was based on both quantitative and qualitative data collected from employees, supervisors, OPs and representatives of the organisation. The results indicated a successful adoption of coss at the organisational level, and a modest implementation of the intervention among OPs, employees and supervisors. There was a limited reach and use of COSS by employees and supervisors. Satisfaction with the intervention varied between intervention parts and situations. Examples of situations wherein the conversation roadmap of COSS was considered to be particularly useful are: a lack of spontaneous contact between the employee and the supervisor and in case employees have psychological health complaints, or an unclear medical prognosis. One (out of five) OPs used the monitoring information to enhance the cooperation between the employee and the supervisor.

A next study showed that COSS did not have significant effects on quality of life or work resumption. Yet, there was a trend towards a positive effect on work resumption (study 5).

The final study assessed the cost -effectiveness -utility and -benefit of coss. The intervention was cost-effective regarding initial RTW (time until first progression in terms of working more hours). The results of the cost utility analysis made clear that cOSS resulted in reduced costs, yet at negligible QALY gains. From an organisational perspective, COSS contributes to a productivity gain of $€ 395.89$ per euro invested (study $6)$.

\section{Reflections on findings}

Our research findings reveal several tensions that can be observed in the process of self-direction in RTW. These tensions cover some pitfalls that need specific attention when supporting self-direction. The tensions are discussed below.

To self-direct or to comply

COSS assumes that self-direction of employees and supervisors equals aiming for a quick RTW. It offers a sort of standardisation aimed at early RTW with a basic quality 
level of cooperation and it helps organisations to be less dependent on situational factors such as the support provided by individual professionals.

This standardisation, however, requires a high level of compliance with the method in order for the intervention to be successful. This can conflict with the principle of selfdirection. For some employees participation in paid work may not be their final goal at all and thus true self-direction may lead them in another direction than RTW. To illustrate, persons with a chronic illness can experience that due to factors such as fatigue they are not able to combine caring for their health with paid work, a family, social activities and so on. These persons may give less priority to paid work [1]. The coss intervention does not allow for such alternative considerations. In line with this, employers in our study showed their disappointment in employees who 'would not undertake enough to return to work' [2-3]. Such individualisation is also visible in the often used Dutch behavioural model of Falke and Verbaan which emphasizes 'sick leave to be a choice of the employee' [4]. Our findings, however, illustrate that a problematic RTW-trajectory is more of a shared-and cooperation problem than an individual problem. Blaming and shaming individuals does not seem to benefit the cooperation in RTW [2-3]. Horstman also emphasized the tendency to moralise the problem of noncompliance with for example interventions. Those who do not comply do not fulfil their civil duty and should deal with the consequences of that [5].

Thus, in line with van $\mathrm{Hal}$, we can state that initiatives to support 'self-direction towards RTW' are rather normative [6]. We consider these initiatives something different than to truly self-direct, which requires actors to be sufficiently autonomous.

To pursue the ideal of participation or take the sick role

We found that employees aim to achieve medical recovery before resuming work, which is supported by the employees' social environment and curative care professionals [2-3]. This also is in line with Karlson, Skargren, and Kristenson [7] who found that in a general middle aged population, high emotional support predicts more sickness absence. Our findings may be understood by Parsons' sick role and the medical model which both claim that one does not have to participate (e.g. in paid work) when being ill. Medical doctors play an important role in supporting sick role behaviour by legitimating sickness (absence). The only obligation for ill persons would be to work on their medical recovery [8]. This sick role idea does not seem to fit with the concept of a participation society, nor with scientific evidence showing that that there is broad consensus about the therapeutic value of work [9-10].

To follow a health process- or time contingent approach

For years, professionals in RTW have followed a process-contingent approach. This means that the progression of RTW is fitted entirely to the pace of the employees' 
medical recovery. This matches with Parson's sick role [8]. On the other hand, the nowadays popular time-contingent approach (in which RTW takes place following a predefined time schedule) may not sufficiently take into account the pace of recovery, which may depend not only on the disease, but also is a derivative of an interaction between characteristics of the individual and disease-characteristics. Because of purely time-contingent interventions, employees may feel pushed to resume work too early.

Regarding psychological health complaints, many Dutch OPs are currently mostly interested in a combination of a process contingent approach within a certain time frame [11]. COSS is in line with this approach in that only the meetings between employees and supervisors regarding RTW follow a time contingent approach. In deciding about the moment of RTW, the state of the employees' health complaints is taken into account. The advantage of this approach is that it provides room to consider both the employers' primary goal (RTW) and that of the employees (medical recovery).

To guide the work resumption process by consensus or difference of power

Our research findings show that employees and supervisors aim for different primary goals (employees: medical recovery / supervisors: RTW) [3]. Similarly, in the recent advice of the Dutch socio-economics council, representatives of employees and employers could not agree about the future of occupational healthcare [12]. Thus, in the beginning employees and supervisors have rather different perspectives on sick leave and RTW.

COSS is a consensus-based intervention. The conversation roadmap explicitly invites both the employees and the supervisors to contribute to the RTW plan. It is questionable whether consensus-based interventions are optimally effective when nothing is done to limit the power difference between employees and supervisors. Our research has shown that supervisors can decide about the employees' work resumption themselves (without consulting the employees) later during sick leave [3]. Particularly in times of economic crisis, the power difference may be large. Initiatives to support selfdirection in RTW may be particularly challenging in situations where the power difference between employees and employers is relatively large. For example, having a lower education can be a bottleneck for RTW [13]. These employees may experience more struggle to self-direct RTW in relation to their employers.

Also, COSS is complementary to Dutch legislation that seems to strengthen the power difference. Dutch legislation only prescribes employees' and employers' role taking behaviour regarding RTW such as meetings. Thereby, the legislation mainly supports employers to achieve their primary goal [3, 14-15]. 
To develop generic interventions or to acknowledge that one size does not fit all

Our study results about the effectiveness and cost-effectiveness of our generic intervention cOSS are promising. Yet, the results of our process evaluation illustrate that COSS was useful as a generic intervention that can best be applied in uncertain situations (i.e. psychological health complaints, unclear medical prognosis, lack of trust or spontaneous contact between employees and supervisors, lack of supervisors' experience with supporting absent employees), rather than a 'one size fits all approach'. Maiwald [16] has also found that inflexible arrangements for work resumption are counterproductive.

To achieve quick or sustainable results

Nowadays there is a trend towards focusing on sustainable labour participation $[9,17-$ 18]. Changing to self-direction in RTW usually implies a change of the organisational culture. Such cultural change is difficult to realise and often takes a lot of time [19]. Regarding COSS, no aftercare was provided to the banking organisation. In general, organisations tend to spend limited money on interventions to support such sustainable results. Employers tend to underestimate the effort that is needed to achieve selfdirection in RTW. Consequently, the sustainability and dissemination of initiatives such as COSS in practice is unsure.

To implement or ignore interventions that reduce costs but show no significant effects

The combined results of the effect- and economic evaluation show that coss yielded a cost reduction when compared to common practice. However, coss was not significantly more effective regarding work resumption and quality of life than common practice. This complicates decision-making about the broader implementation of the intervention. From an employers' and income insurers' perspective, the positive financial return of COSS can be sufficient argumentation for a wide implementation of the intervention. However, it is also important to take the RTW-needs as experienced by individual employees and supervisors into account. In our process evaluation for instance, a supervisor who has extensive experience with supporting absent employees, mentioned to be afraid that COSS might provoke superficial conversations about RTW. Thus, in specific situations COSS may even be disadvantageous to the RTW process. When interventions such as COSS are not supported by employees and supervisors, they can in the long run, result in dissatisfaction and lack of motivation. Thereby, the interventions will be counterproductive to the organisations. It can be challenging to combine the economic- and effectiveness perspective with that of individual employees and supervisors in decision-making about COSS and similar interventions in practice. 
Overall, the concept of self-direction in RTW goes hand in hand with several tensions that need careful consideration by policy makers and professionals in practice such as HR professionals and occupational physicians. A thoughtful approach of self-direction can help to achieve better results in practice.

\section{Discussion of intervention development}

Our intervention, COSS, was based on the findings related to the first thesis aim. We decided to develop a generic intervention, for all absent employees, regardless of their diagnoses. This decision was made because employers in the Netherlands are not allowed to ask employees about their health complaints. Also, cooperation activities for employees and employers are prescribed by Dutch legislation to all absent employees, regardless of their diagnoses. Thus, generic interventions that are complementary to this legislation may be effective. In addition, the results of the first three studies together provide evidence for factors that play a role in the cooperation between the absent employees and their supervisors, regardless of the employees' medical diagnoses. An example factor is a lack of open communication about RTW. These considerations overruled the finding of our systematic review showing that generic interventions were ineffective [20]. This result, however, was based on only three generic interventions that were developed for other countries than the Netherlands.

Further, the first three studies included in this thesis described a broad variety of bottlenecks and facilitators for self-direction in RTW. Our central focus in this thesis was on the employees' and employers' self-direction in RTW. Consequently, we aimed to focus COSS only at the bottlenecks and facilitators that concerned the cooperation between the employees and their employers. This study is part of a larger research project, named 'Work and Care' in which multiple interventions are studied, including primary- and secondary care [21]. Probably, most bottlenecks for- and facilitators of RTW that we found in this study, but were not included in cOSs (such as multidisciplinary intervention), were covered by the other interventions.

\section{Methodological reflections}

A particular strength of the results of the first three studies is that they provided an adequate overview of facilitators of- and bottlenecks for sick-listed employees and their supervisors' self-direction in RTW. We studied the perspectives of multiple stakeholders such as employees, supervisors and OPs $[2-3,20]$. In many previous studies, a one stakeholder- perspective was studied. A strength of the process evaluation is triangulation of different quantitative and qualitative data, which enabled us to draw a more complete picture of the implementation of coss [22]. Similarly, we evaluated 
coss from three different perspectives: 'process', 'effectiveness', and 'cost effectiveness, -utility, and benefit'. However, this research also has some limitations and unexpected results.

\section{Direct supervisors}

A limitation of the research performed for the first thesis aim is that we interviewed $H R$ professionals. We chose to do so, because they have more extensive experience than supervisors with supporting absent employees. During the interviews they talked about their own experiences as well as about that of supervisors in their organisations. Because COSS targets at the supervisor, it may have been better to directly study the experiences and opinions of the supervisors themselves.

\section{cOSS not significantly effective but cost-effective}

At first sight, it is striking that COSS was found to be cost-effective, but not significantly effective regarding work resumption. However, it is important to interpret the results of the cost-effectiveness evaluation and the effect evaluation correctly.

First, an effect evaluation focuses on testing the significance of an intervention effect. Our sample size was too small to show such significant effects. Therefore, there was a lack of statistical power in our study [22]. An economic evaluation, on the other hand, focuses on estimating differences in costs and effects and aims to determine the likelihood of an intervention being cost effective. Part of the analysis is to test for sample uncertainty, by bootstrapping. Thus, economic evaluation does not focus at all on testing a specific hypothesis regarding cost effectiveness [23]. The uncertainty analysis using bootstrapping showed that the intervention has a probability of being cost-effective.

Second, the results of the different economic evaluations detect whether coss, when compared to an alternative intervention (in this case common practice), offers good or better value for money. In health economics, conclusions are based on priority setting (i.e. the incremental effects of the new intervention relative to the incremental costs when compared to common practice). The denominator in the cost-effectiveness ratio (ICER) calculated for COSS covers the incremental gain in initial RTW, and the numerator shows the additional cost of achieving that gain. This joint distribution of differences in cost and effect can illustrate cost effectiveness of an intervention when differences in cost and/or effect separately are not significant [23]. Following this line of reasoning, an intervention can even turn out to be cost effective in case of effectiveness similar to- or smaller than the alternative, as long as the intervention is cheaper than the alternative. In the economic evaluation of our intervention, we found not only a quicker initial RTW in the COSS group, compared to common practice. We also found that at six months follow up, overall costs (healthcare-, patient and family-, and 
productivity costs) were lower in the COSS group when compared to common practice. In the ICER, this joint distribution of differences in cost and effect contributed to the cost-effectiveness of cOSS.

\section{Field research}

We performed field research. That we tested COSS in a real life setting supports the reliability of the findings of our evaluation studies. At the same time, it made our study design vulnerable for bias because external factors had a strong impact on our study. Consequently, this study can be considered more pragmatic than explanatory [24].This pragmatism had a number of limitations.

First, we experienced difficulties to find organisations that would be willing to participate in COSS. We contacted 47 employers, insurers and occupational health services. Reasons for non-participation were, for example, upcoming organisational change or being interested in COSS, but not in its evaluation studies. Due to the time needed to find an organisation willing to participate in COSS, we had to reduce the follow up period of our effect study by six months.

Second, because of insufficient data, we could not study the assumed mechanism of coss and thereby rule out that the tendency towards effectiveness- and the costeffectiveness of COSS are caused completely by third factors such as differences in 'sick leave culture' between the departments allocated to the COSS and common practice group.

Further, there was a lack of statistical power. Also, from the banking organisation's annual report it showed that already before COSS, employees and supervisors were satisfied with the support level by the Occupational Health Service [25]. This means that common practice is of high quality already. Finally, sick leave in the Netherlands is relatively low at the moment [26]. These factors mean that we studied the effectiveness- and cost-effectiveness of COSS in the least favourable situation. COSS may have turned out to be more effective- and cost-effective, for example in organisations with less extensive sick leave policies.

\section{Implications for research}

The findings regarding the facilitators of- and bottlenecks for self-direction in RTW showed that employees often had different perspectives than supervisors or OPs. Therefore, multiple stakeholder perspectives should explicitly be incorporated in studies to achieve a more complete picture when trying to describe and understand the facilitators of- and bottlenecks for self-direction in RTW.

Further, it is important in an early stage of intervention research to consider the stakeholders (such as employees, supervisors) that will be addressed by intervention. 
The perspectives of these exact stakeholders should be studied to acquire the most useful insights for intervention development.

Besides, several lessons for traditional evaluation studies (e.g. effectiveness study) can be taken from the studies performed for the second aim of this thesis. Researchers in the field of RTW need to be aware that it may take a lot of time to recruit organisations to participate in their interventions. Triangulation of data [22] and perspectives (e.g. process-, effectiveness-, and cost-effectiveness) provides a more comprehensive insight in the added value of an intervention. Further, a sufficiently large sample size and taking proximal outcomes into account (to study the mechanism of an intervention) are necessary to draw clear-cut conclusions about the effectiveness of an intervention.

However, considering the many stakeholders involved in RTW interventions, other types of evaluation may even be more useful. For example, in responsive evaluation and action research there is room for (e.g. negotiation between) multiple stakeholder perspectives [27-28]. When applying these methods, researchers get a more complete, and rich picture of the process of implementing an intervention in practice.

Further, it is important to still develop and test interventions to enhance self-direction of employees and supervisors in RTW when the national sick leave level is relatively low. Regardless of the sick leave level, it is important that employees and supervisors mutually agree on the steps to be taken during the employees' sick leave. This can support them to feel in control of- and be satisfied with the decisions made.

Finally, COSS and similar interventions should be studied in other sectors than banking and in organisations that benefit the most; i.e. that have not so extensively developed sick leave policies.

\section{Implications for practice}

First of all, future interventions should give more autonomy to employees and supervisors to actually take responsibility, in order for self-direction to exist (instead of focusing on letting them comply with the pathway to RTW described by the intervention, as was done by COSS). For example, a format can be introduced of a toolbox with intervention instruments that can be applied, depending on the needs of the specific situation.

Second, although considered from a self-direction perspective, employees are free to act in line with the sick role, they seem unaware of evidence showing that work is, in many cases, considered to be beneficial for their health and wellbeing [10]. Professionals such as OPs should undertake sufficient effort to make employees aware of this. 
Third, future interventions can also follow COSSs' combined process- and timecontingent approach. This gives room for the perspectives of (and thus self-direction by) both employees and supervisors.

Fourth, although it is impossible to empower employees into a completely equal relationship with their employers, power relations are fluid [29]. One way to intervene in the unequal power situation is to develop legislation and policies that state that employees and employers should both support medical recovery and RTW. This can help to support at least more equality in their employment relationship. Also, interventions should be developed for those groups for whom it is less obvious to take self-direction such as lower educated employees and employees in small- and medium enterprises (SMEs). These employers often insure their employees' incomes against the risks of sick leave. The income insurers, however, can use the concept of self-direction in RTW as leverage to get absent employees to resume work quickly. Thereby, the idea of 'self-direction' in practice can mainly support the employers' power over employees. One can also argue that the wage payment obligation prescribed by Dutch legislation puts too much responsibility on SMEs as it can have considerable financial consequences to them [30].

Fifth, our findings show that interventions (such as COSS) should be developed as generic interventions that can best be applied in uncertain situations.

Sixth, time should be invested to change towards self-direction in RTW. This is needed to anchor new approaches in the organisational culture [19].

Finally, though our intervention for self-direction in RTW results in a cost-saving [31], organisations should carefully consider whether it is useful to implement interventions on other grounds than costs as well. Although it can be challenging to include for example the employees' perspective in decision-making, it can result in better outcomes.

Overall, this study underlines the importance and the challenges of adequate cooperation between employees and their supervisors during sick leave and RTW. Such adequate cooperation will help to realise true self-direction by the employees and their supervisors. 


\section{Literature}

1. Klabbers G, Rooijackers B, Goertz Y, de Rijk A. Krachtig en kwetsbaar. Onderzoek naar de ervaringen met arbeidsparticipatie en sociale participatie van mensen met chronische ziekten en beperkingen [Strong and vulnerable. Research on the experiences with labour participation and social participation of people with chronical diseases and disabilities]. Maastricht: Maastricht University; 2014.

2. Hoefsmit N, Houkes I, Nijhuis FJN. Environmental and personal factors that support early return-to-work: A qualitative study using the ICF as a framework. WORK. 2014;48(2):203-15.

3. Hoefsmit N, de Rijk A, Houkes I. Work resumption at the price of distrust: a qualitative study on return to work legislation in the Netherlands. BMC Publ Health, 2013;13:153.

4. Falke W, Verbaan D. Verzuimmodellen. [Sick leave models]. Falke \& Verbaan. No date. http://www.falkeverbaan.nl/expertises/gedragsbeinvloeding/verzuim/verzuimmodellen. Accessed 29 July 2014.

5. Horstman K. Dikke kinderen, uitgebluste werknemers en vreemde virussen. Filosofie van de publieke gezondheidszorg in de 21e eeuw. Inaugurale rede [Overweight children, burned-out employees and strange viruses. Philosophy of public health in the $21^{\text {st }}$ century. Inaugural lecture]. Maastricht: Maastricht University; 2010.

6. van Hal L. Working on activation. Analyses of stories about vocational rehabilitation of people with disabilities in the Netherlands. Maastricht: Maastricht University; 2013.

7. Karlson N, Skargren E, Kristenson M. Emotional support predicts more sickness absence and poorer self assessed work ability: a two-year prospective cohort study. BMC Publ Health. 2010;10:648.

8. Barbour A. Caring for patients. A critique of the medical model. 1st ed. Stanford: Stanford University Press; 1995.

9. Ministry of the Interior and Kingdom relations. De doe-democratie. Kabinetsnota ter stimulering van een vitale samenleving. [The do-democracy. Cabinet note to stimulate a vital society]. Ministry of the Interior and Kingdom relations. 2013. http://www.rijksoverheid.nl/documenten-enpublicaties/publicaties/2013/07/09/kabinetsnota-doe-democratie.html. Accessed 29 July 2014.

10. Waddell G, Burton AK. Is work good for your health and well-being? London: TSO; 2006.

11. van der Klink JJL, Ausems CMM, Beijderwellen BD, Blonk R, Bruinvels DJ, Dogger J, Hoedeman R, Janssen J, Loo M, Nieuwenhuijsen K, Oeij TS, van Rees E, van Rhenen W, de Roos L. Richtlijn handelen van de bedrijfsarts bij werkenden met psychische problemen [Guideline actions of the occupational physician in case of employees with psychological complaints]. Utrecht: NVAB; 2007.

12. Socio-Economics Council. Betere zorg voor werkenden. Een visie op de toekomst van de arbeidsgerelateerde zorg [Better care for workers. A vision on the future of occupational healthcare]. The Hague: Socio-Economics Council; 2014.

13. Burger H, Marincek CRT. Return to work after lower limb amputation. Disabil Rehabil. 2007;29, $1323-9$.

14. Ministry of Social affairs and Employment. Wet Verbetering Poortwachter [Improved Gatekeeper Act]. Ministry of Social affairs and Employment. No date. http://www.arboportaal.nl/onderwerpen/arbowet-en-regelgeving/verzuim/wet- verbetering-poortwachter.html. Accessed 6 March, 2013.

15. Ministry of Social affairs and Employment. Ziekteverzuim van het werk. [Sickness absence]. http://www.rijksoverheid.nl/onderwerpen/ziekteverzuim-van-het-werk. Accessed 11 April 2013.

16. Maiwald K. Does bipartite return-to-work policy work? An evaluation based on stakeholders' experiences in a Canadian healthcare setting. Maastricht: Maastricht University; 2013.

17. Annesly C. Lisbon and social Europe: towards a European 'adult worker model' welfare system. J Europ Soc Pol. 2007;17(3):195-205.

18. Black C. Working for a healthier Tomorrow. London: TSO; 2008.

19. Kotter JP. Leading change. Boston: Harvard Business School Press; 1996.

20. Hoefsmit N, Houkes I, Nijhuis FJN. Intervention characteristics that facilitate return to work after sickness absence: a systematic literature review. J Occ Rehab. 2012;22(4):462-77.

21. Berg M, Buijs P, Nijhuis F. Arbeid en Gezondheidszorg. Onderzoeksprogramma. Augustus 2008. [Work and Healthcare. Research programme. August 2008]. Plexus Medical Group, TNO Kwaliteit van Leven, 
Universiteit Maastricht. 2008. http://www.arbeidenzorg.com/uploads/programmabeschrijving\%20totaal_globaal_aug08.pdf. Accessed 30 July, 2014.

22. Polit D, Beck CT. Nursing Research: Generating and Assessing Evidence for Nursing Practice. 8th ed. Philadelphia: J.B. Lippincott; 2008.

23. Petrou S, Gray A. Economic evaluation alongside randomised controlled trials: design, conduct, analysis, and reporting. BMJ. 2011;342:d1548.

24. Patsopoulos NA. A pragmatic view on pragmatic trials. Dialogues Clin Neurosci. 2011;13(2):217-24.

25. Anonymous reference to annual report of banking organisation. 2011.

26. Statistics Netherlands. Ziekteverzuim op laagste punt sinds 1996 [Sickness absence at lowest level since 1996].http://www.cbs.nl/nl-NL/menu/themas/arbeidsocialezekerheid/publicaties/artikelen/archief/2014/ 2014-4047-wm.htm

27. Guba EG, Lincoln YS. Fourth generation evaluation (1st. ed.). Thousand Oaks, California: Sage Publications; 1989.

28. Koshy V. Action Research for improving educational practice. A step-by-step guide. 2 nd ed. London: Sage publications Ltd; 2011.

29. Wilton N. An introduction to human resource management. London: SAGE publications; 2011.

30. Westhof FMJ. MKB-ondernemers negatief over verantwoordelijkheden bij zieke werknemers [Employers in SMEs negative about responsibilities in case of sick employees]. Zoetermeer: EIM Onderzoek voor Bedrijf en Beleid; 2005.

31. Noben C, Hoefsmit N, Evers S, de Rijk A, Houkes I, Nijhuis FJN. Economic evaluation of a new organizational RTW intervention for Cooperation between Sick-listed employees and their Supervisors (COSS): A field study. Submitted to Plos One. 


\section{Appendix 1}

In this study project, we developed, implemented and evaluated an intervention to enhance COoperation between Sick-listed employees and their Supervisors (COSS). This intervention consists of A) a conversation roadmap for the employees and the supervisors advising about when to meet and what to discuss, B) a regular monitoring of the quality of the cooperation (using an assessment instrument that consisted of questionnaires), and C) extra occupational physician (OP) support to enhance the cooperation if needed. COSS was developed based on the findings of the first three studies included in this thesis (chapters 2-4).

The paragraphs in this appendix describe each of the three intervention instruments, followed by a detailed description of how we translated research findings to coss. 


\section{Conversation roadmap}

The roadmap structures and intensifies cooperation between employees and supervisors. It covers instructions about when to meet (every two weeks during sick leave and one final meeting three weeks after complete work resumption), what to talk about during meetings, how to prepare these conversations and how to evaluate them. The roadmap prescribes four types of conversations (Figure 1).

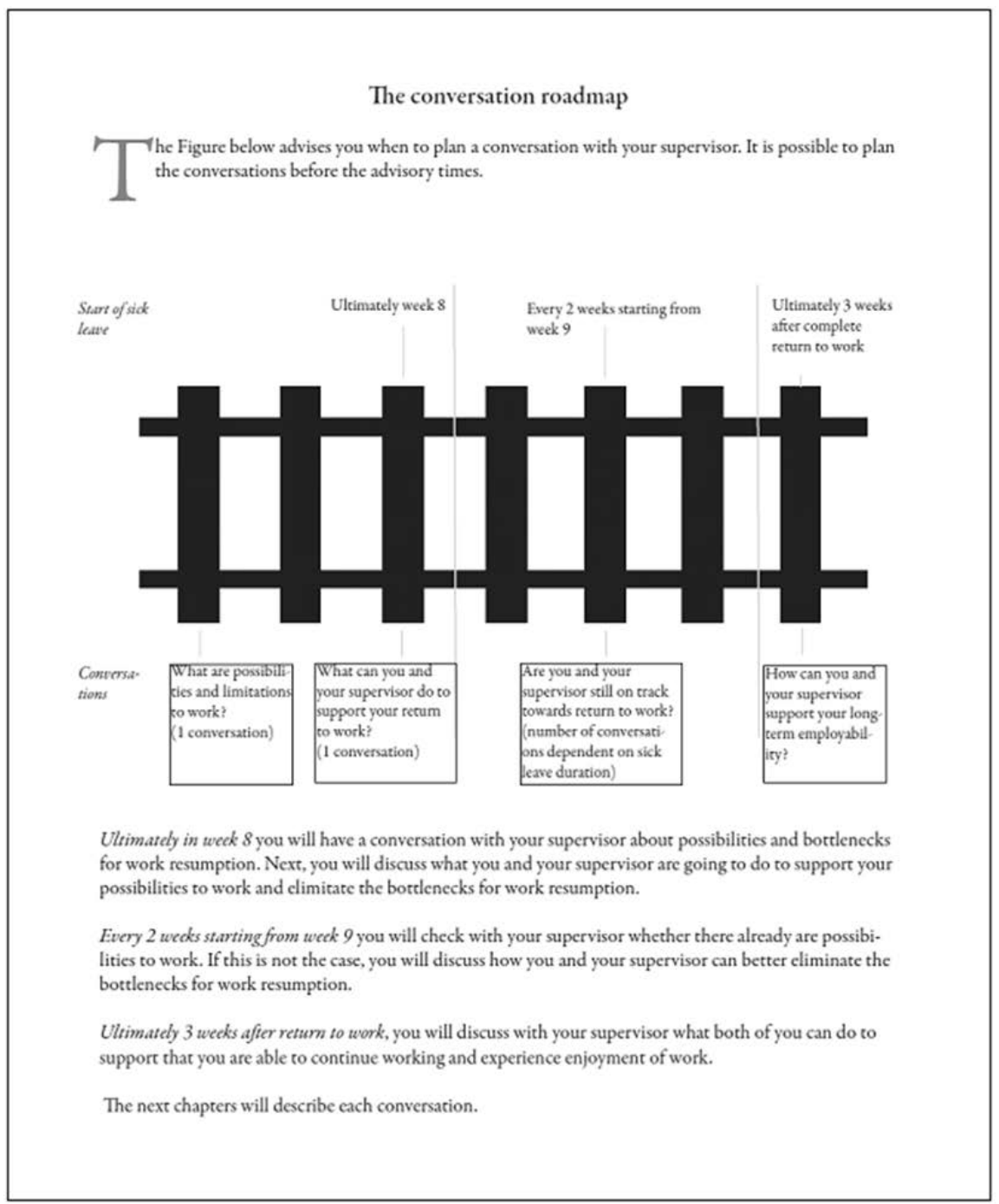

Figure 1. Translated extract of the conversation roadmap. 
The first conversation is about bottlenecks and possibilities for return-to-work (RTW). During the second conversation, the employees and supervisors construct their RTW plans. The first and second conversation are prescribed to take place before the eighth week of sick leave. The third type of conversation (every two weeks after week 8) is about monitoring the progress of RTW. The last conversation (three weeks after complete RTW) is about how to support long-term employability. The employees and supervisors each receive a different version of the conversation roadmap (covering the same topics, described from the perspective of either the employee or the supervisor).

\section{Monitoring of cooperation}

coss also covers a regular monitoring of the quality of cooperation between the employees and supervisors (using questionnaires). Both the employees and the supervisors fill out a monitoring questionnaire: at the beginning of COSS, in the eighth week of sick leave and every twelfth week afterwards until complete work resumption. In case employees and supervisors started COSS in for example the sixth week of sick leave, they did not receive the second monitoring questionnaire.

\section{Extra support by OP to enhance cooperation}

Finally, based on an analysis of the monitoring questionnaires using pre-determined cut-off scores, an advice was formulated for the OP about whether and how to improve the cooperation between the employees and their supervisors. The participating OPs took part in a preparation meeting. Yet, OPs were free to choose whether, when, how, and where they undertook effort to enhance the cooperation between the absent employees and their supervisors.

\section{Translation of research findings to COSS}

COSS focuses at five variables. These are specific characteristics of the cooperation between sick-listed employees and their supervisors in the RTW process that need to be improved by COSS. Chapter 5 describes the five variables in more detail. The variables are translated to the three instruments of COSS (Table 1). 
Table 1. Translation of variables to coss

\begin{tabular}{|c|c|c|c|c|}
\hline \multirow[b]{2}{*}{$\begin{array}{l}\text { Variable: } \\
\text { what }\end{array}$} & \multirow[b]{2}{*}{$\begin{array}{l}\text { Operationalization: } \\
\text { how }\end{array}$} & \multicolumn{3}{|l|}{ Instruments } \\
\hline & & $\begin{array}{l}\text { Conversation } \\
\text { roadmap }\end{array}$ & $\begin{array}{l}\text { Monitoring } \\
\text { questionnaires }\end{array}$ & $\begin{array}{l}\text { Examples of extra } \\
\text { support by OP }\end{array}$ \\
\hline $\begin{array}{l}\text { Planned } \\
\text { and time- } \\
\text { contin-gent } \\
\text { meetings } \\
\text { regarding } \\
\text { RTW }\end{array}$ & $\begin{array}{l}\text { Composing and } \\
\text { monitoring an action } \\
\text { plan for RTW during } \\
\text { meetings that are } \\
\text { planned according to a } \\
\text { pre-defined time } \\
\text { schedule }\end{array}$ & $\begin{array}{l}\text { The timeline in the } \\
\text { roadmap follows a } \\
\text { planned- and time } \\
\text { contingent approach } \\
\text { of meetings }\end{array}$ & $\begin{array}{l}4 \text { self-developed } \\
\text { items, response } \\
\text { range: 0-4 } \\
\text { Example item: } \\
\text { 'Together with your } \\
\text { supervisor/employee, } \\
\text { you make a plan for } \\
\text { RTW' }\end{array}$ & $\begin{array}{l}\text { OP can help to clarify } \\
\text { employees' and } \\
\text { supervisors' } \\
\text { perspectives on a } \\
\text { planned- and time- } \\
\text { contingent approach } \\
\text { of meetings and bring } \\
\text { them together (i.e. to } \\
\text { support employees } \\
\text { and supervisors to } \\
\text { follow the timeline in } \\
\text { the roadmap as much } \\
\text { as possible) }\end{array}$ \\
\hline $\begin{array}{l}\text { Open } \\
\text { communi- } \\
\text { cation }\end{array}$ & $\begin{array}{l}\text { Being honest about } \\
\text { possibilities and issues } \\
\text { for RTW }\end{array}$ & $\begin{array}{l}\text { The roadmap asks } \\
\text { employees and } \\
\text { supervisors to } \\
\text { communicate openly } \\
\text { about possibilities and } \\
\text { issues for RTW }\end{array}$ & $\begin{array}{l}5 \text { self-developed } \\
\text { items, response } \\
\text { range: 0-3 } \\
\text { Example item: 'My } \\
\text { supervisor/employee } \\
\text { and I are honest to } \\
\text { each other' }\end{array}$ & $\begin{array}{l}\text { OP can help to clarify } \\
\text { employees' and } \\
\text { supervisors' } \\
\text { perspectives and } \\
\text { bring them together }\end{array}$ \\
\hline $\begin{array}{l}\text { Sharing } \\
\text { decision } \\
\text { making } \\
\text { about RTW }\end{array}$ & $\begin{array}{l}\text { Taking shared- and } \\
\text { satisfying decisions about } \\
\text { when and how to RTW } \\
\text { (e.g. number of hours) }\end{array}$ & $\begin{array}{l}\text { The roadmap asks } \\
\text { employees and } \\
\text { supervisors to share } \\
\text { decision-making } \\
\text { about RTW }\end{array}$ & $\begin{array}{l}4 \text { self-developed } \\
\text { items, response } \\
\text { ranges: 0-1, 1-9, 1-2, } \\
\text { 1-10 } \\
\text { Example item: 'How } \\
\text { satisfied are you with } \\
\text { decisions about } \\
\text { RTW?' }\end{array}$ & $\begin{array}{l}\text { OP can help to clarify } \\
\text { employees' and } \\
\text { supervisors' } \\
\text { perspectives (on how } \\
\text { decisions should be } \\
\text { made) and bring them } \\
\text { together }\end{array}$ \\
\hline $\begin{array}{l}\text { Symbiotic } \\
\text { depen- } \\
\text { dence }\end{array}$ & $\begin{array}{l}\text { Feeling that one needs } \\
\text { the other to achieve ones } \\
\text { primary goal. Employees } \\
\text { feel dependent on } \\
\text { supervisors for adequate } \\
\text { RTW possibilities (with } \\
\text { modifications of work } \\
\text { and/or working hours), } \\
\text { that support medical } \\
\text { recovery / Supervisors } \\
\text { feel dependent on } \\
\text { employees for effort to } \\
\text { achieve RTW and for } \\
\text { providing information } \\
\text { (about work abilities or } \\
\text { suggestions for } \\
\text { modification) that is }\end{array}$ & $\begin{array}{l}\text { The roadmap covers } \\
\text { statements to } \\
\text { convince employees } \\
\text { and supervisors of } \\
\text { their mutual } \\
\text { symbiotic } \\
\text { dependence }\end{array}$ & $\begin{array}{l}1 \text { self-developed item, } \\
\text { response range: 1-3 } \\
\text { Example item: 'I need } \\
\text { cooperation with my } \\
\text { supervisor/employee } \\
\text { to realize adequate } \\
\text { RTW (that contributes } \\
\text { to health)' }\end{array}$ & $\begin{array}{l}\text { OP can help to clarify } \\
\text { employees' and } \\
\text { supervisors' } \\
\text { perspectives and } \\
\text { bring them together } \\
\text { (by convincing } \\
\text { employees and } \\
\text { supervisors that they } \\
\text { need cooperation } \\
\text { with each other). OP } \\
\text { is aware of the role of } \\
\text { norms and beliefs } \\
\text { held by e.g. } \\
\text { employees' family or } \\
\text { care professional } \\
\text { about RTW and } \\
\text { medical recovery. }\end{array}$ \\
\hline
\end{tabular}




\begin{tabular}{|c|c|c|c|c|}
\hline \multirow[b]{2}{*}{$\begin{array}{l}\text { Variable: } \\
\text { what }\end{array}$} & \multirow[b]{2}{*}{$\begin{array}{l}\text { Operationalization: } \\
\text { how }\end{array}$} & \multicolumn{3}{|l|}{ Instruments } \\
\hline & & $\begin{array}{l}\text { Conversation } \\
\text { roadmap }\end{array}$ & $\begin{array}{l}\text { Monitoring } \\
\text { questionnaires }\end{array}$ & $\begin{array}{l}\text { Examples of extra } \\
\text { support by OP }\end{array}$ \\
\hline & $\begin{array}{l}\text { needed for the } \\
\text { supervisors to come up } \\
\text { with an offer for } \\
\text { modification of work } \\
\text { and/or working hours } \\
\text { that aims to support the } \\
\text { employees' medical } \\
\text { recovery, to in the end } \\
\text { facilitate early and } \\
\text { sustainable RTW. }\end{array}$ & & & \\
\hline Trust & $\begin{array}{l}\text { Thinking that the other is } \\
\text { reliable }\end{array}$ & $\begin{array}{l}\text { The roadmap } \\
\text { structures the RTW- } \\
\text { process to some } \\
\text { extent, which can } \\
\text { prevent employees } \\
\text { from thinking that the } \\
\text { supervisor would aim } \\
\text { for RTW too early and } \\
\text { supervisors from } \\
\text { thinking that } \\
\text { employees would not } \\
\text { aim for RTW. }\end{array}$ & $\begin{array}{l}\text { Questionnaire, which } \\
\text { consists of } 3 \text { items, } \\
\text { response range: 1-5 } \\
\text { [1] } \\
\text { Example item: 'I have } \\
\text { confidence in my } \\
\text { supervisor/employee' } \\
9 \text { self-developed } \\
\text { items, response } \\
\text { range: 0-3 } \\
\text { Example item: 'I think } \\
\text { I/ the employee will } \\
\text { return to work when } \\
\text { my supervisor/l } \\
\text { indicate that this is } \\
\text { needed' }\end{array}$ & $\begin{array}{l}\text { OP can help to clarify } \\
\text { employees' and } \\
\text { supervisors' } \\
\text { perspectives (i.e. } \\
\text { communicate about } \\
\text { trust) and bring them } \\
\text { together (i.e. } \\
\text { acknowledge each } \\
\text { other's' role in the } \\
\text { work resumption } \\
\text { process). }\end{array}$ \\
\hline
\end{tabular}

The variables (first column) are the five points of improvement in the cooperation between the absent employees and their supervisors. The operationalisation (second column) indicates how each variable needs improvement. Each variable is translated to intervention instrument(s) (columns 3-5). All variables are addressed by all three intervention instruments: the conversation roadmap, monitoring questionnaires and extra cooperation support by an OP. Finally, the monitoring reports and the preparation session for OPs also aims to support more standardised role taking by this professional. 


\section{Literature}

1. Boskemper DA, de Jong RD. "The forgotten ones" nader onderzocht: Onderling vertrouwen als mediator en persoonlijkheid als moderator in het verband tussen leiderschapsstijl en arbeidsprestatie en welbevinden" ["The forgotten ones" further studied: mutual trust as a mediator and personality as a moderator in the relation between leadership style and work performance and well-being]. Utrecht: Universiteit Utrecht; 2008. 


\section{Summary}

This thesis focuses on employees' and supervisors' self-direction in return-to-work (RTW). The first study aim was to create an overview of the facilitators of- and bottlenecks for sick-listed employees' and their supervisors' self-direction in RTW in multiple target populations and across interventions. This overview resulted from a systematic literature review and two qualitative interview studies.

The second study aim was to develop and evaluate a generic, organisational intervention to support sick-listed employees' and their supervisors' self-direction in RTW. The intervention aims to support COoperation between Sick-listed employees and their Supervisors (COSS). It consists of three instruments: A) a conversation roadmap for the employees and the supervisors advising about when to meet and what to discuss, B) a regular monitoring of the quality of the cooperation (using an assessment instrument consisting of questionnaires), and C) extra occupational physician (OP) support to enhance the cooperation if needed. COSS was implemented in a large Dutch banking organisation and we performed a process-, effect-, and economic evaluation of the intervention.

Chapter 1 describes the relevance of studying employees' and supervisors' selfdirection in RTW in detail. It also describes the Dutch legislation regarding RTW, the thesis aims and the methodology used. We know from earlier research that employees and supervisors can encounter several bottlenecks for RTW. Self-direction is needed for employees and supervisors to adequately steer the RTW-process. Existing initiatives to support self-direction of individual employees and supervisors are promising but often focused at specific health complaints such as burnout or accessible via healthcare providers or insurers. This does not support implementation of successful practices at organisational level. It is more feasible for e.g. employers to apply one intervention to all absent employees, regardless of their diagnoses than to apply several specific interventions. Therefore, we developed and evaluated COSS. To develop this intervention, we needed an overview of the facilitators of- and bottlenecks for sicklisted employees' and their supervisors' self-direction in RTW in multiple target populations and across interventions. Previous studies were focused particularly at specific diagnoses, included only one stakeholder perspective (e.g. that of the employee), did not provide sufficient and/or in-depth understanding of the facilitators of- and bottlenecks for RTW.

Chapter 2 describes a systematic literature review. The aim of this study was to detect and identify characteristics of RTW interventions that generally facilitate return to work (i.e. in multiple target populations and across interventions). We included 23 publications in our review. These were both quantitative studies and systematic literature reviews. First, we assessed all studies regarding their methodological quality, 
which was moderate to good for the quantitative studies and good to very good for the systematic literature reviews. Then, we assessed several characteristics of interventions using a self-developed taxonomy and we described the characteristics' effectiveness regarding RTW. The results showed that early interventions facilitated RTW, as was also the case for the majority of the multidisciplinary interventions. Time contingent and activating interventions (that for example included taking a decision about work resumption) were effective in target populations consisting of employees with physical health complaints. Evidence regarding time contingent interventions was somewhat inconsistent in psychological complaints. Inconsistent results were also found regarding interventions for employees with specific health complaints such as low back pain, interventions with diverse intensities (i.e. high ( $\geq 10 \mathrm{~h}$ divided over multiple sessions), moderate ( $<10 \mathrm{~h}$ divided over multiple sessions) or low intensity (once)) and interventions that provide decision authority (for example regarding the timing of RTW) to employees and/or employers. Finally, interventions developed for all employees, regardless of their diagnoses, showed no significant effects.

Chapter 3 is a qualitative interview study. The aims were to study (1) which environmental and personal factors support employees' RTW and how they support RTW, and (2) to examine whether professionals can use the ICF to describe these factors. We analysed data from semi-structured interviews with 14 employees, $15 \mathrm{HR}$ professionals and 5 OPs. The results described the following environmental factors: social support by relatives, the belief that RTW can contribute to medical recovery, adequate cooperation between stakeholders in RTW (i.e. employees, employers, curative professionals, OPs and the social insurance office; this factor covers, among others, the adequacy of medical treatment), and the supervisors' communicative skills. The results also described a personal factor, which is the employees' positive perception of the situation (e.g. enjoyment of the work). All factors supported RTW, except for social support and the adequacy of medical treatment that supported both medical recovery and RTW. Only the environmental factors could partially be classified by ICF coding.

Chapter 4 is a qualitative interview study as well. It was focused on the following research questions: 1) To what degree is there cooperation between Dutch sick-listed employees and employers? 2) How can this (lack of) cooperation be understood? and 3) How valid is the RDIC model for understanding this (lack of) cooperation? We analysed data from semi-structured interviews with 8 employees and 8 employers. The study results showed a low degree of cooperation during the first year of absence and a moderate degree during the second. The (lack of) cooperation could be understood by a lack of experienced willingness of employees (first year) or supervisors (second year) to cooperate. Multiple factors were underlying (the lack of) willingness to cooperate: not experiencing dependency, i.e. need to cooperate for achieving medical recovery (employees, first year) or RTW (employers, second year), not feeling stimulated by legislation (employees, first year), experiencing distrust (employees, first year / 
supervisors, second year), and a difference of norms (employees: RTW after medical recovery / supervisors: RTW during medical recovery). Besides, during both years of sick leave, employees and supervisors reported a moderate ability to cooperate, which particularly could be understood by having moderate practical resources (e.g. having time to meet but lacking knowledge of legislation). Overall, the RDIC model appeared to be valid for describing and understanding the cooperation. Yet, the factor distrust also played a role in the cooperation, which was not included in the RDIC model. These findings illustrate that legislation can ensure a minimum degree of cooperation between employees and employers (only if legislation covers rules about cooperation). However, for adequate cooperation one also needs trust, knowledge about the legislation, and awareness of a mutual dependence on each other for achieving ones goals. Personal norms regarding the goals also play a role. Professionals in RTW can support these factors to achieve a degree of cooperation that is necessary to establish effective RTW.

Chapter 5 describes the development of COSS, based on the findings described in chapters 2-4. Chapter 5 also describes a process evaluation of COSS. Our research questions were: 1) How was coss adopted by the organisation? 2) How was coss implemented among individual employees, supervisors and OPs? We used quantitative and qualitative data for the evaluation (online questionnaire, conversation minutes, project administration, semi-structured interviews and emails). Regarding the adoption, representatives of the organisation reported positively (e.g. fit with existing sick leave policy) and negatively (e.g. high intensity) towards the intervention. Further, the results indicated a modest reach and use of COSS by individual employees and supervisors. Satisfaction with COSS varied across intervention parts (the majority of the responding employees and supervisors were satisfied with the OP support) and situations (e.g. roadmap was considered useful for employees with psychological complaints). Preconditions for COSS were, e.g. that supervisors had sufficient time to use the intervention. Overall, the results illustrate a good adoption of COSS by the banking organisation and an only partial implementation of the intervention among individual employees, supervisors and OPs.

Chapter 6 provides an effect evaluation of coss. In a field study, coss was compared to common practice. The aim of this study was to detect whether cOSS achieves better results concerning quality of life, first RTW (time until first progress made in working hours), full RTW (time until complete work resumption), and sustainable RTW (time until lasting complete RTW, i.e. working for four weeks without relapse in partial or complete sick leave) when compared to common practice. We used sick leave data from the participating organisation and self-reported data about quality of life and we used data about several demographical characteristics of employees. In total 64 employees received COSS or common practice. No significant group differences were found regarding all study outcomes. Yet, the results regarding work resumption show a tendency towards effectiveness. The lack of significant 
intervention effects was attributed to methodological factors (such as the small sample size), the intervention itself which may be improved (e.g. a questionnaire was not an adequate tool to monitor the cooperation) and the limited implementation of cOSS.

Chapter 7 describes an economic evaluation of COSS. The objective of this study was to assess the cost -effectiveness, -utility, and -benefit of COSS compared with common practice. Outcomes were initial RTW (calendar days from employee inclusion until initial work resumption), quality adjusted life years (QALYS), and productivity gains. Compared to common practice, COSS was cost effective regarding initial RTW. The cost utility analysis showed a cost reduction. Yet, gain in QALYs was uncertain. From an organizational perspective, cOSS resulted in a positive financial return. These study results suggest that COSS has a large potential to reduce costs and improve productivity and quality of life. Research with a longer follow up is needed to study whether coss supports sustainable work resumption in a cost-effective way.

Chapter 8 describes the main findings of the studies included in this thesis and the diverse tensions that can exist in the process of self-direction in RTW. This chapter also includes a discussion of intervention development, a methodological reflection and implications for research and practice.

A major tension is that COSS equals self-direction to aiming for a quick RTW. COSS provides standardised pathway towards RTW, which requires employees and supervisors to comply with the intervention, more than to self-direct. Therefore, future interventions should focus on supporting true self-direction of employees and supervisors. Another tension is that the ideal of participation conflicts with the sick role type of thinking (which, our research has shown, is still very common among employees). Although, considering the self-direction approach, employees are free to take the sick role, they seem unaware of the potential positive effects of work on health and wellbeing. RTW professionals should make them aware of this.

Strengths of this research include triangulation of stakeholders and evaluation perspectives (process, effectiveness and cost -effectiveness, -utility and -benefit). An important limitation of this research is that COSS was tested in the least favourable situation (there was a lack of statistical power, common practice was of good quality already and sick leave was relatively low at participating organisation).

An example of an implication for future research is that COSS and similar interventions should be studied in organisations that benefit most (i.e. that do not have such extensive sick leave policies). An example of an implication for practice is that interventions (such as COSS) should be developed as generic interventions that can best be applied in uncertain situations.

This study underlines the importance and the challenges of adequate cooperation between employees and their supervisors during sick leave and RTW. In the end, such adequate cooperation will help to realise true self-direction by the employees and their supervisors. 


\section{Samenvatting}

Het onderwerp van dit proefschrift is eigen regievoering over werkhervatting door de verzuimende werknemer en de leidinggevende. Het eerste studiedoel was om een overzicht te creëren van de bevorderende factoren en de belemmeringen voor eigen regievoering over werkhervatting door verzuimende werknemers en hun leidinggevenden, in meerdere doelgroepen en voor verschillende typen interventies. Dit overzicht was het resultaat van een systematische literatuurreview en twee kwalitatieve interviewstudies.

Het tweede studiedoel was om een generieke organisatie-interventie te ontwikkelen en te evalueren. De interventie is gericht op het ondersteunen van eigen regievoering over werkhervatting door verzuimende werknemers en hun leidinggevenden. Om deze eigen regievoering te bereiken, is de interventie gericht op het bevorderen van samenwerking tussen verzuimende werknemers en hun leidinggevenden (COoperation between Sick-listed employees and their Supervisors, COSS). De interventie bestaat uit drie instrumenten: A) een draaiboek voor de werknemers en de leidinggevenden over wanneer elkaar te ontmoeten en wat te bespreken, B) een reguliere monitoring van de kwaliteit van de samenwerking (gebruikmakend van een assessment instrument bestaande uit vragenlijsten), en C) extra ondersteuning door de bedrijfsarts om de samenwerking indien nodig te verbeteren. COSS werd geïmplementeerd in een grote Nederlandse bank en we hebben een proces-, effect-, en economische evaluatie van de interventie uitgevoerd.

Hoofdstuk 1 beschrijft gedetailleerd de relevantie van het bestuderen van eigen regievoering over werkhervatting door werknemers en leidinggevenden. Het beschrijft ook de wetgeving over werkhervatting, de doelen van het proefschrift en de gebruikte methodologie. We weten uit eerder onderzoek dat werknemers en leidinggevenden vele knelpunten voor werkhervatting tegen kunnen komen. Eigen regievoering door werknemers en leidinggevenden is nodig om het werkhervattingsproces adequaat te sturen. Bestaande initiatieven om eigen regievoering door individuele werknemers en leidinggevenden te ondersteunen zijn veelbelovend maar vaak gericht op specifieke gezondheidsklachten zoals burnout of uitsluitend toegankelijk via zorgverleners of verzekeraars. Dit bevordert niet de implementatie van succesvolle praktijken op organisatieniveau. Het is meer haalbaar voor bijvoorbeeld werkgevers om een interventie toe te passen bij alle verzuimende werknemers ongeacht hun diagnoses, dan om vele specifieke interventies toe te passen. Daarom hebben we coss ontwikkeld en geëvalueerd. Voor de ontwikkeling van deze interventie hadden we een overzicht nodig van de bevorderende factoren en knelpunten voor verzuimende werknemers en hun leidinggevenden om eigen regie te voeren over werkhervatting in meerdere doelgroepen en voor verschillende typen interventies. Eerdere studies waren met name 
gericht op specifieke diagnoses, omvatten slechts een stakeholder perspectief (bijvoorbeeld dat van de werknemer), boden onvoldoende en/of te weinig diepgaand begrip van de bevorderende factoren en knelpunten voor werkhervatting.

Hoofdstuk 2 beschrijft een systematische literatuurstudie. Het doel van deze studie was om eigenschappen van werkhervattingsinterventies te identificeren die over het algemeen werkhervatting bevorderen (d.w.z. in meerdere doelgroepen en voor verschillende typen interventies). We hebben 23 publicaties in onze review geïncludeerd. Dit waren zowel kwantitatieve studies als systematische literatuurstudies. Als eerste werd de methodologische kwaliteit van alle studies geëvalueerd, welke matig tot goed was voor de kwantitatieve studies en goed tot zeer goed voor de systematische literatuurreviews. Vervolgens hebben we vele interventie-eigenschappen geëvalueerd, gebruikmakend van een zelf ontwikkelde taxonomie en we hebben de effectiviteit van de eigenschappen met betrekking tot werkhervatting beschreven. De resultaten lieten zien dat vroege interventies werkhervatting faciliteerden, zoals ook het geval was bij de meerderheid van de multidisciplinaire interventies. Tijdcontingente en activerende interventies (die bijvoorbeeld het nemen van een beslissing over werkhervatting omvatten) waren effectief bij doelgroepen bestaande uit werknemers met fysieke gezondheidsklachten. Bewijs met betrekking tot tijdcontingente interventies was ietwat inconsistent bij psychische klachten. Inconsistente resultaten zijn ook gevonden met betrekking tot interventies voor werknemers met specifieke gezondheidsklachten zoals lage rugpijn, interventies met verschillende intensiteiten (d.w.z. hoog ( $\geq 10$ uur verdeeld over meerdere sessies), matig ( $<10$ uur verdeeld over meerdere sessies) of lage intensiteit (eenmalig)) en interventies die beslissingsbevoegdheid (bijvoorbeeld met betrekking tot de timing van werkhervatting) geven aan werknemers en/of werkgevers. Tot slot lieten interventies ontwikkeld voor alle werknemers, ongeacht hun diagnoses, geen significante effecten zien.

Hoofdstuk 3 is een kwalitatieve interviewstudie. De doelstellingen waren (1) het bestuderen van omgevings- en persoonlijke factoren die werkhervatting door de werknemer kunnen ondersteunen, en (2) het onderzoeken van de bruikbaarheid van het ICF model voor het beschrijven van deze factoren. Data van semi-gestructureerde interviews met 14 werknemers, $15 \mathrm{HR}$ professionals en 5 bedrijfsartsen zijn geanalyseerd. De resultaten beschreven de volgende omgevingsfactoren: sociale steun door familie, het geloof dat werkhervatting kan bijdragen aan medisch herstel, adequate samenwerking tussen stakeholders tijdens werkhervatting (d.w.z. werknemers, werkgevers, curatieve professionals, bedrijfsartsen en het Uitvoeringsinstituut Werknemersverzekeringen (UWV); deze factor omvat, onder andere, de adequaatheid van medische behandeling), en de communicatieve vaardigheden van leidinggevenden. De resultaten beschreven ook een persoonlijke factor, namelijk een positieve werknemersperceptie van de situatie (bijv. plezier hebben in het werk). Alle factoren ondersteunden werkhervatting, met uitzondering van sociale steun en de adequaatheid van de medische behandeling die zowel medisch herstel als werkhervatting 
ondersteunden. Enkel de omgevingsfactoren konden gedeeltelijk worden geclassificeerd aan de hand van ICF codes.

Hoofdstuk 4 is eveneens een kwalitatieve interviewstudie. Deze studie was gericht op de volgende onderzeksvragen: 1) In welke mate is er samenwerking tussen Nederlandse verzuimende werknemers en werkgevers? 2) Hoe kan dit (gebrek aan) samenwerking worden begrepen? en 3) Hoe valide is het RDIC model voor het begrijpen van dit (gebrek aan) samenwerking? Data van semi-gestructureerde interviews met 8 werknemers en 8 werkgevers zijn geanalyseerd. De resultaten lieten een lage graad van samenwerking zien gedurende het eerste jaar van ziekteverzuim en een matige graad gedurende het tweede jaar. Het (gebrek aan) samenwerking zou kunnen worden begrepen door een gebrek aan ervaren motivatie door werknemers (eerste jaar) of leidinggevenden (tweede jaar) om samen te werken. Meerdere factoren lagen ten grondslag aan het (gebrek aan) motivatie tot samenwerking: het niet ervaren van afhankelijkheid, d.w.z. de noodzaak om samen te werken voor het bereiken van medisch herstel (werknemers, eerste jaar) of werkhervatting (leidinggevenden, tweede jaar), het niet gestimuleerd voelen door de wetgeving (werknemers, eerste jaar), het ervaren van wantrouwen (werknemers, eerste jaar / leidinggevenden, tweede jaar) en een verschil van normen (werknemers: werkhervatting na medisch herstel / leidinggevenden: werkhervatting gedurende medisch herstel). Bovendien rapporteerden werknemers en leidinggevenden een matig vermogen tot samenwerking tijdens beide verzuimjaren. Dit kan vooral worden begrepen door het hebben van matige praktische middelen (bijv. wel tijd hebben om bijeen te komen maar tevens een gebrek aan kennis over de wetgeving). Over het algemeen bleek het RDIC model valide te zijn voor het beschrijven en begrijpen van de samenwerking. Toch speelde de factor wantrouwen ook een rol in de samenwerking, en deze factor was geen onderdeel van het RDIC model. Deze bevindingen illustreren dat wetgeving een bepaald minimum aan samenwerking tussen werknemers en werkgevers kan verzekeren (alleen als de wetgeving regels over samenwerking omvat). Echter, voor adequate samenwerking heeft men ook nodig: vertrouwen, kennis over de wetgeving, en bewustzijn van een wederzijdse afhankelijkheid voor het bereiken van de eigen doelen. Persoonlijke normen met betrekking tot de doelen spelen ook een rol. Professionals kunnen deze factoren ondersteunen om een graad van samenwerking te bereiken die nodig is voor het bereiken van een effectieve werkhervatting.

Hoofdstuk 5 beschrijft de ontwikkeling van COSS, gebaseerd op de bevindingen beschreven in hoofdstukken 2-4. Hoofdstuk 5 beschrijft ook een procesvaluatie van COSS. De onderzoeksvragen waren: 1) Hoe werd coss geadopteerd door de organisatie? 2) Hoe werd COSS geïmplementeerd bij individuele werknemers, leidinggevenden en bedrijfsartsen? Voor de evaluatie zijn kwantitatieve en kwalitatieve data gebruikt (online vragenlijst, gespreksnotulen, projectadministratie, semigestructureerde interviews en e-mails). Met betrekking tot de adoptie rapporteerden de vertegenwoordigers van de organisatie positief (bijv. een goede match met bestaand 
verzuimbeleid) en negatief (bijv. een hoge intensiteit) ten opzichte van de interventie. Verder gaven de resultaten een bescheiden bereik en gebruik van cOSS aan bij individuele werknemers en leidinggevenden. De tevredenheid met coss varieerde tussen verschillende interventieonderdelen (de meerderheid van de werknemers en leidinggevenden die reageerden was tevreden met de ondersteuning door de bedrijfsarts) en situaties (bijv. het spoorboekje werd als bruikbaar beschouwd voor werknemers met psychische klachten). Randvoorwaarden voor coss waren onder andere dat leidinggevenden voldoende tijd hadden om de interventie te gebruiken. Over het algemeen illustreren de resultaten een goede adoptie van coss door de bank en een slechts gedeeltelijke implementatie van de interventie bij individuele werknemers, leidinggevenden en bedrijfsartsen.

Hoofdstuk 6 beschrijft de effectevaluatie van COSS. In een veldstudie werd COSS vergeleken met de reguliere ondersteuning. Het doel van deze studie was om te onderzoeken of cOSS positieve effecten heeft op kwaliteit van leven, eerste werkhervatting (tijd tot eerste vooruitgang in werkuren), volledige werkhervatting (tijd tot complete werkhervatting), en duurzame werkhervatting (tijd tot blijvende complete werkhervatting, d.w.z. werken gedurende vier weken zonder terugval in gedeeltelijk of volledig verzuim) in vergelijking met de reguliere ondersteuning. Er is gebruik gemaakt van verzuimdata van de participerende organisatie, zelfgerapporteerde data over kwaliteit van leven en gegevens over diverse demografische kenmerken. In totaal 64 werknemers hebben COSS of de reguliere ondersteuning ontvangen. Er zijn geen significante groepsverschillen gevonden met betrekking tot de uitkomstmaten van de studie. Toch lieten de resultaten met betrekking tot werkhervatting een tendens naar een positief effect zien. Het gebrek aan significante effecten is toegeschreven aan methodologische factoren (zoals de kleine steekproefgrootte), de interventie zelf die mogelijk kan worden verbeterd (zo was een vragenlijst geen adequaat instrument om de samenwerking te monitoren) en de beperkte implementatie van COSS.

Hoofdstuk 7 beschrijft de economische evaluatie van COSS. Het doel van deze studie was om de kosten -effectiviteit, -utiliteit, en -baten van COSS in vergelijking met de reguliere ondersteuning te bepalen. Uitkomstmaten waren initiële werkhervatting (kalenderdagen van inclusie van de werknemer tot aan initiële werkhervatting), voor kwaliteit gecorrigeerde levensjaren (quality adjusted life years, QALYs), en productiviteitswinst. In vergelijking met de reguliere ondersteuning was coss kosteneffectief met betrekking tot initiële werkhervatting. De kostenutiliteitsanalyse toonde een kostenreductie aan. Toch was de winst in QALY's onzeker. Vanuit organisatieperspectief bezien, resulteerde COSS in een positief rendement. Deze studieresultaten suggereren dat coss een groot potentieel heeft om kosten te reduceren en om de productiviteit en kwaliteit van leven te verbeteren. Onderzoek met een langere doorlooptijd is nodig om te bestuderen of cOSS duurzame werkhervatting ondersteunt op een kosteneffectieve manier. 
Hoofdstuk 8 beschrijft de belangrijkste bevindingen van de studies uit dit proefschrift en de diverse spanningen die kunnen bestaan in het proces van eigen regievoering over werkhervatting. Dit hoofdstuk omvat ook een discussie van de interventieontwikkeling, een methodologische reflectie en implicaties voor onderzoek en praktijk. Een groot spanningsveld bestaat erin dat COSS eigen regievoering gelijk stelt aan het streven naar een snelle werkhervatting. COSS biedt een gestandaardiseerd pad richting werkhervatting, wat van werknemers en leidinggevenden vereist dat zij zich schikken naar de interventie, meer dan dat zij zelf regie voeren. Daarom moeten toekomstige interventies focussen op het ondersteunen van echte eigen regievoering door werknemers en leidinggevenden. Een ander spanningsveld is dat het ideaal van participatie conflicteert met het denken volgens de ziekenrol (die, zo heeft ons onderzoek laten zien, nog steeds zeer gangbaar is onder werknemers). Hoewel werknemers gezien de eigen regie benadering vrij zijn om de ziekenrol aan te nemen, lijken zij zich niet bewust te zijn van de potentiële positieve effecten van werk op gezondheid en welbevinden. Professionals op het gebied van werkhervatting moeten hen daarvan bewustmaken. Sterke kanten van dit onderzoek omvatten triangulatie van stakeholders en evaluatieperspectieven (proces, effectiviteit en kosten -effectiviteit, -utliteit, en -baten). Een belangrijke beperking van dit onderzoek is dat COSS is getest in de minst gunstige situatie (er was een gebrek aan statistische power, de reguliere ondersteuning was al van goede kwaliteit en het ziekteverzuim was relatief laag bij de participerende organisatie). Een voorbeeld van een implicatie voor toekomstig onderzoek is dat COSS en soortgelijke interventies moeten worden bestudeerd in organisaties die het meest profiteren (d.w.z. die nog niet een dergelijk uitgebreid verzuimbeleid hebben). Een voorbeeld van een implicatie voor de praktijk is dat interventies (zoals COSS) worden ontwikkeld als generieke interventies die het beste kunnen worden toegepast in onzekere situaties.

Deze studie onderstreept het belang- en de uitdagingen van adequate samenwerking tussen werknemers en leidinggevenden gedurende ziekteverzuim en werkhervatting. Dergelijke adequate samenwerking zal uiteindelijk helpen om echte eigen regievoering door werknemers en hun leidinggevenden te realiseren. 



\title{
Valorisation of the research findings
}

\author{
'Science for its own sake' usually means nothing more than science for the sake of the \\ people who happen to be pursuing it
}

\author{
Rudolph Virchow, 'Standpoints in Scientific Medicine', \\ Disease, Life, and Man: Selected Essays 1958, 42.
}

Rudolph Virchow, one of the founders of Social Medicine, already emphasized the importance of making research matter to practice. Yet, the gap between Social Medicine research and practice is still large. It often takes years before research findings are applied in practice, if at all.

Since long, there have been discussions among academics about whether they should take a role in valorising research findings and if so, what this role should look like. In my opinion, researchers should take effort themselves to bridge the gap between research and practice. They should give back valuable knowledge and insights to the same society that made their research possible in the first place. Researchers can do this in a variety of ways, such as by giving presentations to professionals who work on 'their' topic in practice, developing knowledge centres, cooperating with professionals to solve practice problems or sending out press releases about study findings. To support these activities, I think that it is important that researchers at universities in general receive more credit for their societal impact.

\section{What should be valorised}

This thesis focused on the topic of self-direction of sick-listed employees and their supervisors in return-to-work (RTW). Despite that the results of this research do not point in the direction of a ready-made intervention, several findings together can be considered as a knowledge base which has the potential to be valorised.

We aimed to support employees' and supervisors' self-direction in order to cooperate better. This thesis covers a description of facilitators of- and bottlenecks for this cooperation. Examples of bottlenecks concern a lack of trust and shared decisionmaking regarding RTW. Also, this thesis describes the development-, implementationand evaluation of an intervention to enhance the Cooperation between Sick-listed employees and their Supervisors (COSS). The research findings together can be considered to be a huge overview of best practices and bottlenecks to avoid in order to enhance cooperation between sick-listed employees and their supervisors. For example, 
the findings describe how distrust between sick-listed employees and their supervisors can come about and what its consequences can be. Moreover, the findings suggest that adequate efforts to support the implementation of RTW-policy in practice are of vital importance.

\section{Why it is innovative and relevant}

The knowledge that resulted from this research is innovative and relevant to Dutch RTW practice, for two reasons.

First, many existing RTW-interventions were focused on specific health complaints such as burnout or low back pain. COSS was developed to be a generic intervention that can be applied to all absent employees, regardless their health complaints. Generic interventions are relevant to Dutch employers as it is not allowed to ask employees in the Netherlands about their health complaints.

Second, many organisations provide return to work support. To my knowledge, there are no well-known organisations that primarily and directly support both the individual sick-listed employee and his/her supervisor to cooperate adequately. The cooperation approach supports employees and supervisors equally to take their shared responsibility in the RTW process.

\section{How it was valorised}

During the PhD research, we performed several activities to valorise the findings of this research.

First, after finishing the research for the first thesis aim, we contacted 47 employers, insurers and occupational health services to invite them to participate in coss and its evaluation. We visited a considerable part of these organisations to present our main findings regarding the facilitators of- and bottlenecks for the cooperation between sick-listed employees and their supervisors. By doing this, we informed a target population consisting of among others HR professionals, occupational physicians, managers, directors and policy makers. Many of these professionals were convinced of the need to resolve the bottlenecks for the cooperation between sicklisted employees and their supervisors in practice.

Second, on 13 April 2010, we presented at the invitational conference 'Work and Healthcare'. We presented similar content as we offered to the 47 employers, insurers and occupational health services (i.e. facilitators of- and bottlenecks for the cooperation between sick-listed employees and their supervisors). Visitors of the conference included occupational physicians and reintegration companies [1]. At the end of the presentation, there was a lively discussion about the facilitators and bottlenecks.

Third, we presented our findings regarding the first thesis aim (only regarding the cooperation between sick-listed employees and their employers) at the European Public 
Health (EUPHA) conference in 2013. This conference was visited by over 1300 persons from over 60 countries [2]. The visiters included not only researchers but also practice professionals [3]. We also presented our findings about the employers' expectations regarding how employees should take responsibility in tertiary work disability prevention (sick leave and RTW) at the Work Disability Prevention Interventions (WDPI) conference in 2014. This presentation was part of an interactive seminar about the topic of 'worker's responsibilities in work disability prevention- would they, should they, could they?' (presenters: Karin Maiwald, Cindy Noben, Bram Rooijackers, Nicole Hoefsmit; moderator: Angelique de Rijk). An earlier meeting of this conference was visited by 200 persons from 25 different countries. The participants were, among others, employers, human resource managers, insurers and policy-makers [4]. As part of the seminar, in-depth discussion took place. The seminar helped to disseminate the research findings to a broader audience of professionals from several countries.

Fourth, in 2012, we organised an 'ABSG' (accreditation office for social medicine) accredited preparation session for occupational physicians of the banking organisation who agreed to participate in COSS. We informed the occupational physicians about our findings regarding the bottlenecks for cooperation between sick-listed employees and their supervisors. We also presented COSS in detail and provided suggestions regarding how the occupational physicians can provide the extra support of employees and their supervisors (based on the monitoring of the quality of the cooperation). At the end of the preparation session, the occupational physicians were enthousiastic to provide extra support of employees and their supervisors as part of COSS.

Fifth, we presented all major study findings described in this thesis to a selection of HR professionals and the occupational physician related to Maastricht University. At the end of this presentation, discussion took place, particularly about what self-direction in RTW should entail. These professionals had a positive attitude towards the idea behind COSS and a strong intention to support self-direction in RTW.

Sixth, we wrote a report in Dutch for the banking organisation that participated in cOSS and our research. Information in this report can serve as a basis for decisionmaking about adaptation of the organisation's sick leave policy.

Finally, we provided input for the preparation of the advisory trajectory of the Dutch Socio-economics council (Sociaal-Economische Raad, SER) about the future of occupational healthcare. The input covered our main findings regarding the facilitators of- and bottlenecks for the cooperation between sick-listed employees and their supervisors.

Thus, during the research phase, several actions were already taken to valorise the study findings such as presentation of- and discussion about the research findings with professionals in practice.

Our combined process-, effect-, and economic evaluation have shown that coss is potentially very valuable to practice. Therefore, the department of Social Medicine 
considers the option to further develop and evaluate the cOSS intervention, based on the findings of our process evaluation.

Overall, this research has a large potential for valorisation. The results of this thesis are relevant to many stakeholders in the RTW process such as employees, supervisors, HR professionals and occupational physicians. They can use the study results in RTW practice. For example, knowledge about bottlenecks for- and facilitators of selfdirection in RTW can be used to shape organisations' RTW policy. Also, the knowledge can inspire RTW professionals to further improve their service on an individual level. 


\section{Literature}

1. Tilstra F. Arbeid \& Zorg. Verslag van de conferentie op 13 april 2010. Vertrouwen in samenwerking. [Work \& Care. Report about the conference on 13 April 2010. Trust in cooperation]. 2010. http://www.arbeidenzorg.com/uploads/verslag\%20conferentie\%20arbeid\%20en\%20gezondheid\%20260 42010.pdf. Accessed 7 January 2015.

2. European Public Health Conference. 6th European Public Health Conference. Health in Europe: are we there yet? Learning from the past, building the future. SQUARE Meeting Centre, Brussels, 13-16 November 2013. 2013. http://ephconference.eu/conference-2013-brussels-62. Accessed 7 January 2015.

3. European Public Health Conference. 6th European Public Health Conference. Health in Europe: are we there yet? Learning from the past, building the future. 13-16 November 2013, Brussels, Belgium. Results of the participants' evaluation. http://ephconference.eu/repository/conference/2013/Brussels_2013_participants_evaluation.pdf. Accessed 7 January 2015.

4. International Conference of the Work Disability Prevention and Integration. 3th WDPI Conference: Implementing Work Disability Prevention Knowledge. 2014. http://wdpi2014.iwh.on.ca/. Accessed 7 January 2015. 



\section{Dankwoord}

Promoveren is een langdurig proces en een proefschrift is een product van samenwerking met velen. Graag wil ik iedereen bedanken die een rol heeft gespeeld aan de totstandkoming ervan.

Als eerste wil ik mijn copromotoren Inge Houkes en Nicolle Boumans en mijn promotor Frans Nijhuis bedanken. Ik ben blij en dankbaar dat jullie mij de mogelijkheid hebben geboden om dit onderzoek uit te voeren. Jullie afzonderlijke kwaliteiten vulden elkaar in de begeleiding goed aan. Dit maakte onze bijeenkomsten tot plezierige contacten waarvan ik veel heb geleerd.

Inge Houkes, ontzettend bedankt voor je dagelijkse begeleiding. Vanaf het begin tot het einde van het onderzoek kon ik altijd bij jou aankloppen- letterlijk en figuurlijk. Als ik even niet verder kwam, bijvoorbeeld door problemen met het werven van deelnemers, dan hielp je altijd om oplossingen te vinden. Vaak liet je alles direct uit je handen vallen om mij te helpen. Ik heb veel geleerd van jouw uitgebreide kennis overen inzicht in onderzoeksmethoden, systematisch analyseren en schrijfvaardigheid. Je hebt bovendien altijd vertrouwen in mij gehad en de mogelijkheid gegeven om mij breder te ontwikkelen, bijvoorbeeld op het gebied van onderwijs.

Nicolle Boumans, ook bij jou kon ik altijd aankloppen. Ik heb jouw feedback op analyses en conceptartikelen heel waardevol gevonden. Je keek zeer gedetailleerd naar teksten en hielp bijvoorbeeld om te structureren en onderzoeksbevindingen te duiden. Je hebt mij, met name in het voorlaatste jaar van mijn promotieonderzoek, geholpen om in bredere zin een visie te vormen op het doen van onderzoek.

Frans Nijhuis, ik ben dankbaar voor je vertrouwen in mij als onderzoeker. Onze overleggen waren heel waardevol. Met jouw analytische scherpte wist je mij met vaak enkele cruciale opmerkingen verder op weg te helpen. Hier heb ik veel van geleerd. Bovendien heb ik veel bewondering en respect voor de manier waarop je, ook in moeilijke tijden, betrokken blijft bij dit onderzoek.

Na mijn promotieonderzoek ben ik begonnen als consultant arbeid en organisatie bij ArboNed. Het bedrijfsleven is weliswaar een andere wereld dan een universiteit, maar door mijn samenwerking met jullie heb ik veel kennis en vaardigheden opgedaan die mij goed van pas komen in mijn verdere professionele leven.

Hiernaast wil ik graag enkele andere collega's bedanken. Angelique de Rijk, tijdens onze samenwerking aan het 'cooperation artikel' heb je mij veel geleerd over kwalitatief onderzoek. Ik waardeer het ook erg dat je workshops kwalitatief onderzoek hebt georganiseerd. Verder kijk ik terug op een mooie gezamenlijke presentatie-ervaring tijdens het WDPI congres (Canada) in september 2014. Miriam Janssen, bedankt voor het aanbieden van een coördinerende rol in de training Disability Awareness en het houden van een vraaggesprek. Van onze samenwerking heb ik geleerd om complexe taken te organiseren. Isel van Noppen, heel erg bedankt voor alle hulp zoals het inplannen van afspraken. Frans Feron, bedankt dat je mij als vakgroepvoorzitter de mogelijkheid hebt gegeven om dit onderzoek binnen de afdeling Sociale Geneeskunde af te ronden. 
Cindy Noben (UM), Romy Steenbeek (TNO), Myrthe van Vilsteren (EMGO instituut, Vumc), Sanneke de Smit (KPMG Plexus) en Kees de Kock (Radboudumc), bedankt voor onze fijne samenwerking aan het Stichting Instituut GAK-project Arbeid en Zorg. Cindy, jou wil ik heel erg bedanken voor je werk aan de economische evaluatie. Vooral in de analysefase hebben we heel wat telefoongesprekken gevoerd over de datakwaliteit. Je hebt de analyses een aantal keer opnieuw uitgevoerd wanneer we weer eens een manier hadden ontdekt om de data verder te optimaliseren.

Verder bedank ik dr. Boudien Krol en prof. dr. Peter van Lieshout voor hun interesse in dit onderzoek tijdens de jaarlijkse projectbijeenkomsten. Ik bedank hen ook voor het verlenen van medewerking aan de financiering van dit onderzoek.

Ik bedank de leescommissie: Prof. dr. Fred Zijlstra, Prof. dr. IJmert Kant, Prof. dr. Han Anema, Prof. dr. Sandra Brouwer en Prof. dr. Hans Bosma voor het beoordelen van dit proefschrift. Dank ook aan de (overige) leden van de corona.

Hiernaast wil ik de vele geïnterviewden bedanken. Interviews met werknemers vonden meestal bij hen thuis plaats. Hun gastvrijheid was bijzonder. Soms werd gebak in huis gehaald, of mocht ik kennismaken met huisdieren. De openheid van de geïnterviewden heb ik als heel behulpzaam ervaren. Ik bedank ook de deelnemers aan de interventie en de vertegenwoordigers van de organisatie die ervoor hebben gezorgd dat de interventie in de eerste plaats kon worden uitgevoerd. Om privacy-redenen noem ik geen namen, maar dit maakt hun rol niet minder belangrijk.

Verder bedank ik de medisch secretaresses van de organisatie waar de interventiestudie is uitgevoerd. Zonder hen had de interventiestudie niet door kunnen gaan. Inge van der Putten, bedankt voor je ondersteuning tijdens de uitvoeringsfase.

Dit onderzoek heb ik gedaan aan de afdeling SOCIALE geneeskunde, een heel prettige plek om te werken. Ik bedank mijn collega's inclusief de externe promovendi en enkele oud-Socmed collega's voor de vele fijne gesprekken. Elena en Cindy, ontzettend fijn dat jullie mijn paranimfen willen zijn. Bedankt voor alle hulp die jullie hebben geboden bij de organisatie van de promotie. Hiernaast bedank ik de paranimfen en de andere collega's die hebben geholpen bij de inhoudelijke voorbereiding van de promotie.

Ik bedank mijn ouders en broer Stefan. Ik kon altijd bij mijn ouders terecht voor een luisterend oor en advies wanneer ik daarnaar vroeg. In bredere zin steunen jullie mij altijd in de keuzes die ik maak, wat ik heel erg waardeer.

Sander, dankjewel voor jouw steun. Dit is voor mij heel belangrijk geweest. Wij hebben vaak ook inhoudelijk over het onderzoek gepraat. In die zin ben jij nu eigenlijk ook gespecialiseerd in de samenwerking tussen de verzuimende werknemer en de leidinggevende. 


\section{About the author}

Nicole Hoefsmit was born on the $22^{\text {nd }}$ of April 1986 in Heerlen, the Netherlands. In 2004, she completed the Athenaeum at Bernardinuscollege in Heerlen. Upon that, she followed the Bachelor of Public Health with a major in Work and Health and a minor in Care Sciences at Maastricht University. Meanwhile, she completed the Honours programme of the Faculty of Health Medicine and Life Science. As part of this programme, she presented her research at the Uganda conference of the network Towards Unity For Health (TUFH). In 2007, she started with the Master's programme Work and Health at Maastricht University. The topic of her Master thesis was: 'Does age matter in the employability of police officers?' After obtaining her Master degree in 2008, she was employed as a junior researcher at the department of Social Medicine for over two years. In March 2011, she started a PhD trajectory at the same department. While working as a junior researcher and PhD student, she performed several educational tasks, varying from supervision of a student during her thesis period, to training and coordination activities. She also was a member of the advisory committee of a research project named 'Dialogue-driven reintegration'. Further, she provided input for the preparation of the advisory trajectory of the Dutch Socio-economics council (Sociaal-Economische Raad, SER) concerning the future of occupational healthcare. In December 2014, Nicole became a Work and Organisational consultant at ArboNed. 
